\title{
Remedies for human rights violations by the European Union
}

Citation for published version (APA):

Antoniades, A. E. (2021). Remedies for human rights violations by the European Union. [Doctoral Thesis, Maastricht University]. Maastricht University. https://doi.org/10.26481/dis.20210604aa

Document status and date:

Published: 01/01/2021

DOI:

10.26481/dis.20210604aa

Document Version:

Publisher's PDF, also known as Version of record

\section{Please check the document version of this publication:}

- A submitted manuscript is the version of the article upon submission and before peer-review. There can be important differences between the submitted version and the official published version of record.

People interested in the research are advised to contact the author for the final version of the publication, or visit the DOI to the publisher's website.

- The final author version and the galley proof are versions of the publication after peer review.

- The final published version features the final layout of the paper including the volume, issue and page numbers.

Link to publication

\footnotetext{
General rights rights.

- You may freely distribute the URL identifying the publication in the public portal. please follow below link for the End User Agreement:

www.umlib.nl/taverne-license

Take down policy

If you believe that this document breaches copyright please contact us at:

repository@maastrichtuniversity.nl

providing details and we will investigate your claim.
}

Copyright and moral rights for the publications made accessible in the public portal are retained by the authors and/or other copyright owners and it is a condition of accessing publications that users recognise and abide by the legal requirements associated with these

- Users may download and print one copy of any publication from the public portal for the purpose of private study or research.

- You may not further distribute the material or use it for any profit-making activity or commercial gain

If the publication is distributed under the terms of Article $25 \mathrm{fa}$ of the Dutch Copyright Act, indicated by the "Taverne" license above, 


\title{
Remedies for human rights violations by the European Union
}

\author{
to obtain the degree of Doctor at the Maastricht University, \\ on the authority of the Rector Magnificus, \\ Prof.dr. Rianne M. Letschert \\ in accordance with the decision of the Board of Deans, \\ to be defended in public \\ on Friday, June $4^{\text {th }} 2021$, at 12:00 hrs.
}

\section{by}

\section{Alexis E. Antoniades}

\author{
Approved \\ Prof. dr. Rianne M. Letschert \\ Rector Magnificus
}




\section{Supervisors:}

Prof.dr. Cees van Dam

Prof.dr. Bruno de Witte

Assessment Committee:

Prof.dr. Gijs van Dijck (chair)

Prof.dr. Albertina Albors-Llorens, University of Cambridge, UK

Prof.em. Margot Horspool, University of Surrey, UK

Dr. Lilian Tsourdi 


\section{Table of Contents}

ABBREVIATIONS - Xi

ACKNOWLEDGMENTS 2

$\begin{array}{ll}\text { SUMMARY } & 3\end{array}$

INTRODUCTION

A. Introducing the research question

1. Europe and human rights

2. Introducing the concept of responsibility and remedies for $\quad 7$

violations of human rights by the $E U$

B. The role of this thesis and the academic discourse on the EU 9 and Human Rights

1. The identification of the necessity of a system of remedies for the

EU vis-à-vis human rights

2. Addressing the question and substantially contributing to the

academic discourse on the EU and human rights

C. Terminology - human and fundamental rights 17

D. Plan and structure of this thesis $\quad 19$

PART I - THE REMEDIES DEFICIT

Chapter 1 - The failure of EU Accession to the ECHR and the

remedies deficit

A. Introduction $\quad 24$

B. The history of the ECHR in EU law 24

C. The effects of non-accession: no reform for remedies within 33 


\section{the EU's legal system}

D. The effects of non-accession: continuing inaccessibility to 36 ECtHR remedies

1. Binding judgments of international tribunals and the CJEU 36

2. Inability to access substantive remedies and achieve execution of 39

ECtHR judgments

i. Substantive remedies within the framework of the ECHR 39

ii. Execution of judgments within the ECHR framework 45

iii. The EU, substantive remedies and execution of judgments of the 47

ECHR

$\begin{array}{ll}\text { E. Conclusion } & 48\end{array}$

Chapter 2 - The action for annulment-an inaccessible internal

remedy

A. Introduction $\quad 49$

B. A potentially effective remedy $\quad 49$

1. The relationship between annulment and human rights 49

2. Two rights - related grounds of review

i. Essential procedural requirements

ii. Infringement of the Treaties and any Rule Relating to their 55

Application

C. Standing - an insurmountable obstacle?

D. Limited scope for access to the remedy of annulment $\quad 67$

1. Competence Areas where Judicial Review may occur 67

2. The Jurisdiction of the CJEU in CFSP matters and human hights 69

3. Geographical scope of judicial review and human rights 75

$\begin{array}{ll}\text { E. Conclusion } & 79\end{array}$

Chapter 3 - Alternatives to the ECHR and the Judicial Review

$\underline{\text { Remedies }}$ 
$\begin{array}{lr}\text { A. Introduction } & 80\end{array}$

B. The indirect remedies provided by direct effect and $\quad 80$

preliminary references

C. The plea of illegality: another alternative for fundamental 92

rights protection to Article 263 TFEU?

D. Existent alternatives to the ECHR remedies beyond the EU's 93

legal system

$\begin{array}{lr}\text { E. Conclusion } & 94\end{array}$

PART II NON-CONTRACTUAL LIABILITY OF THE 96

EUROPEAN UNION AND THE PROTECTION OF HUMAN

RIGHTS

Chapter 4 - Introducing the relationship between non-contractual

liability and human rights claims

$\begin{array}{ll}\text { A. Introduction } & 99\end{array}$

B. The legal provisions and theoretical underpinning of non- 99

contractual liability

C. Introducing the criteria of Article 340 TFEU

102

D. Significance of interim relief for the protection of rights

within the action for damages procedure

E. Applicability of non-contractual liability to human rights

violations

Chapter 5 - Non-contractual liability: the concept of unlawfulness

and human rights

A. Introduction 
B. Unlawfulness in Damages Actions and the Protection of Rights

C. The need for sufficiently serious breach - the human rights perspective

D. Discretionary vs. non-discretionary acts - a redundant distinction for rights-based cases?

E. Conclusion

Chapter 6 - Damage, causation and the principle of noncontractual liability of the EU vis-à-vis human rights claims

A. Introduction

B. Remediable damage and human rights

C. Causation and human rights

1. "Damage following directly or sufficiently directly"

2. Indirectly caused damage and human rights

3. Expansion of EU policies, causation and human rights

D. 'Damage' and 'unlawfulness'- may they be the same concept in fundamental rights claims?

E. Comparing the CJEU's approach to damages for the vindication of a right per se with domestic law and European human rights law

1. Domestic legal systems

2. European Court of Human Rights

F. Conclusions

Chapter 7 - EU non-contractual liability for lawful acts and rightsbased claims
A. Introduction
B. The liability for lawful acts in EU law and human rights
C. Is the exception in FIAMM useful for rights-based cases? 
Chapter 8 - The scope of application of the principle of noncontractual liability and human rights

$\begin{array}{ll}\text { A. Introduction } & 166\end{array}$

B. Type of acts covered by non-contractual liability and human 166 rights

C. Institutions, bodies, agencies and organs subject to the principle and the protection of human rights

D. Competence areas covered

E. Conclusions

PART III - THE EUROPEAN UNION AND INTERNATIONAL HUMAN RIGHTS OBLIGATIONS

Chapter 9 - The EU and its involvement in international affairs

A. Introduction

$B$. The $\mathbf{E U}$ in the context of non-state actors in international law

C. The EU - an international organisation with a foreign and defence policy liable to breach human rights

D. Conclusion

Chapter 10 - Does the EU have international human rights obligations?

A. Introduction

B. The conditions for the existence of an international obligation

C. The necessity of accession to a multilateral international 
human rights instrument guaranteeing a sufficient range of human rights

D. The alternative solution of indirect obligations and indirect review

E. Obligations arising out of customary international law and jus cogens

F. Conclusions

Chapter 11 - The EU and the doctrine of attribution in international law

$\begin{array}{ll}\text { A. Introduction } & 215\end{array}$

B. The doctrine of attribution in public international law 215

C. The criteria for holding the EU responsible as an international 221 organisation

D. Case law on attribution and the EU

E. Observations on the rules on attribution and their applicability to the case of the $\mathrm{EU}$

Chapter 12 - The EU's responsibility vis-à-vis Member States' obligations to implement EU policies

A. Introduction

B. Member States as implementing policies of executive federalism

C. Member States implementing Union obligations and international human rights law

D. Conclusions 
A. Introduction

B. The consequences of a breach of international law by an international organisation

C. The meaning of victim, damage and reparation

D. Remedies

1. Restitution

2. Compensation

3. Satisfaction

E. Conclusions

Chapter 14 - Procedural obstacles: available legal fora to challenge the EU on the basis of an internationally wrongful act violating human rights

\section{A. Introduction}

B. The International Court of Justice and the Court of Justice of the European Union

1. The International Court of Justice

2. The Court of Justice of the EU applying international law vis-à-vis human rights violations by the $E U$

C. Suggestions of the UNHCHR Regarding Potential Scrutiny of EU Action

D. Case Study: the EULEX Panel

E. Proposals for a world human rights court

F. Conclusions

\section{CONCLUSION}

I. Revisiting the research question 
II. Summary of Findings 276

III. Proposals 286

A. The CJEU's jurisdiction must be expanded to comprise all areas of Union action and all EU agencies, bodies and institutions 286

B. The CJEU ought to become more open to human rights claims 287 through its case law

C. The EU ought to accede to more international human rights instruments and accept the jurisdiction of their compliance mechanisms

D. Arrangements should be made by establishing specialist bodies or cooperating with international institutions to establish the EU's accountability with regard to its human rights obligations, the lack of set of international human rights obligations for the EU and the inadequate jurisdiction of the CJEU

IV. Final Observations

IMPACT PARAGRAPH

TABLE OF CASES 


$\begin{array}{ll}\text { ABRS } & \text { Afdeling Bestuursrechtspraak van de Raad van State } \\ \text { AC } & \text { Appeal Cases } \\ \text { AFSJ } & \text { Area of Freedom, Security and Justice } \\ \text { AG } & \text { Advocate General } \\ \text { AJIL } & \text { American Journal of International Law } \\ \text { All ER } & \text { All England Law Reports } \\ \text { ARIO } & \text { Draft Articles on the Responsibility of International Organisations } \\ \text { Bull EC } & \text { Bulletin of the European Communities } \\ \text { BVerfGE } & \text { Bundesverfassungsgericht } \\ \text { CA } & \text { Court of Appeal } \\ \text { CAP } & \text { Common Agricultural Policy } \\ \text { CAT } & \text { Convention Against Torture } \\ \text { CCP } & \text { Common Commercial Policy } \\ \text { CDE } & \text { Cahiers de droit européen } \\ \text { CE } & \text { Conseil d'État } \\ \text { CFI } & \text { Court of First Instance } \\ \text { CFSP } & \text { Common Foreign and Security Policy } \\ \text { CJEU } & \text { Court of Justice of the European Union } \\ \text { CLJ } & \text { Cambridge Law Journal } \\ \text { CLR } & \text { Cyprus Law Reports } \\ \text { CMLR } & \text { Common Market Law Reports } \\ \text { CMLRev } & \text { Common Market Law Review } \\ \text { CRPD } & \text { Convention on the Rights of Persons with Disabilities } \\ \text { CSDP } & \text { Common Security and Defence Policy } \\ \text { DAA } & \text { Draft Accession Agreement } \\ \text { DG } & \text { Directorate General } \\ \text { EAW } & \text { European Arrest Warrant } \\ \text { EBLR } & \text { European Business Law Review } \\ \text { EC } & \text { European Community } \\ \text { ECB } & \text { European Central Bank } \\ & \end{array}$




\begin{tabular}{|c|c|}
\hline ECHR & European Convention on Human Rights \\
\hline ECLR & European Constitutional Law Review \\
\hline ECJ & European Court of Justice \\
\hline ECSC & European Coal and Steel Community \\
\hline EC Treaty & European Community Treaty \\
\hline EComHR & European Commission of Human Rights \\
\hline ECtHR & European Court of Human Rights \\
\hline EEA & European Economic Area \\
\hline EEAS & European External Action Service \\
\hline EEC & European Economic Community \\
\hline EHRR & European Human Rights Reports \\
\hline EHRLR & European Human Rights Law Review \\
\hline EJIL & European Journal of International Law \\
\hline ELJ & European Law Journal \\
\hline ELR & European Law Review \\
\hline EMS & European Monetary System \\
\hline ESM & European Stability Mechanism \\
\hline EU & European Union \\
\hline EULEX & European Union Rule of Law Mission in Kosovo \\
\hline Euratom & European Atomic Energy Community \\
\hline Europol & European Union Agency for Law Enforcement Cooperation \\
\hline EWCA & England and Wales Court of Appeal \\
\hline EWHC & England and Wales High Court \\
\hline FRA & Fundamental Rights Agency \\
\hline FRONTEX & European Border and Coast Guard Agency \\
\hline GATS & General Agreement on Trade in Services \\
\hline GATT & General Agreement on Tariffs and Trade \\
\hline GCEU & General Court of the European Union \\
\hline Harv ILJ & Harvard International Law Journal \\
\hline HL & House of Lords \\
\hline HRLJ & Human Rights Law Journal \\
\hline
\end{tabular}




\begin{tabular}{ll} 
HRLR & Human Rights Law Review \\
ICCPR & International Covenant on Civil and Political Rights \\
ICESCR & International Covenant on Economic, Social and Cultural Rights \\
ICJ & International Court of Justice \\
ICLQ & International Law Quarterly \\
ICTY & International Criminal Tribunal for the Former Yugoslavia \\
IJEL & International Journal of European Law \\
ILC & International Law Commission \\
ILO & International Labour Organisation \\
IMO & International Maritime Organisation \\
IR & Irish Reports \\
ITLOS & International Tribunal for the Law of the Sea \\
JHA & Justice and Home Affairs \\
MEP & Member of the European Parliament \\
NATO & North Atlantic Treaty Organisation \\
OECD & Organisation for Economic Cooperation and Development \\
OJ & Official Journal of the European Communities \\
OLAF & European Anti-Fraud Office \\
OSCE & Organisation for Security and Cooperation in Europe \\
PJCC & Police and Judicial Cooperation in Criminal Matters \\
PCIJ & Permanent Court of International Justice \\
RCADI & Recueil des Cours de l'Académie de Droit International \\
SEA & Single European Act \\
TEU & Treaty on the European Union \\
TFEU & Treaty on the Funcitoning of the European Union \\
UKHL & United Kingdom House of Lords \\
UKSC & United Kingdom Supreme Court \\
UN & United Nations \\
UNCLOS & United Nations Convention on the Law of the Sea \\
UNDHR & United Nations Declaration of Human Rights \\
UNRIAA & United Nations Reports of International Arbitral Awards \\
\hline ITH &
\end{tabular}


WTO

YBEL
World Trade Organisation

Yearbook of European Law 
REMEDIES FOR HUMAN RIGHTS VIOLATIONS BY THE EUROPEAN UNION 



\section{ACKNOWLEDGMENTS}

When I first began with my legal studies in 2007, the possibility of writing and completing a doctoral thesis seemed distant, if not unthinkable. At the end of my research, I can only feel grateful for the incredible experience that this has been. The research and drafting of the present thesis, has been a long process during which I have learned many things about law, yet much more about discipline, determination and perseverance.

This thesis would not have been completed without a person who has guided me and stood next to me from the final year of undergraduate studies in London: prof. Cees van Dam. Prof. van Dam has truly been a supervisor, a mentor and a friend. His influence on how I have come to understand legal and academic work has been immense. It was under his tutelage that I first came in contact with research and academia. My gratitude for his patience, support and knowledge that he so generously offered, is infinite.

I also wish to give many thanks my second supervisor, prof. Bruno de Witte. His contribution to the present thesis has been most substantial. Indeed, the development of the research has been greatly shaped by his suggestions. His extensive experience and knowledge of European law has proven to be extremely valuable.

These acknowledgments would not be complete without thanking the people who worked the hardest in order for me to achieve this goal. Those are my family: my father Elias, my mother Andry and my brother Stephanos. It is my parents who instilled in me the thirst for knowledge and the love of learning, that I will cherish as the most important heritage for the rest of my life. 



\section{SUMMARY}

This Thesis has as its core research question the availability of substantive remedies for individual applicants, relating to breaches of fundamental and human rights by EU institutions. The basis of the hypothesis is that the substantive remedies available to individuals for human rights violations by the European Union are limited and regularly ineffective, due to procedural obstacles.

This book will explore its subject in a tripartite structure. The objective of the first Part of this Thesis is to elaborate the initial hypothesis; that is that there is a significant deficit in the access to remedies for human rights violations that are committed by the EU. The first Chapter of Part I explores the problems that persist following the non-fulfilment of the EU's accession to the European Convention on Human Rights. Chapter 2 concerns a fundamental question of EU administrative law with extensive effect on the protection of human rights: the limited effectiveness of the procedure of judicial review within EU law. Chapter 3 examines legal alternatives that may function as mechanisms for the attainment of remedies for violations of human rights: the doctrine of direct effect, preliminary references, the plea of illegality and the establishment of specialist bodies that examine complaints for specialised organs of the EU.

In light of the deficit of remedies identified, other solutions may be sought for obtaining remedies for human rights violations. Consequently, Part II examines the remedy provided by the principle of non-contractual liability as embodied in Article 340(2) TFEU. Chapter 4 will delve into the relationship between non-contractual liability and human rights claims. Next, the criteria for the establishment of non-contractual liability will be examined vis-à-vis human rights cases. Those criteria are unlawfulness (Chapter 5) damage and causation (Chapter 6). This discussion will also include comparisons with national law and the jurisprudence of the ECtHR. Chapter 7 examines the function of the doctrine of non-contractual liability for lawful acts of the Union in human rights. Chapter 8 will assess the material scope of application of the principle of non-contractual liability and how this relates to the remedy's effectiveness for human rights violations. 
Part III goes a step beyond the EU's legal system. It aims to examine the possibility of obtaining remedies for violations of human rights by the EU in the sphere of international law, both as an alternative to the EU's legal system as well as potential additional protection. This part of the thesis will explore the external, international accountability of the Union in relation to human rights violations. Chapter 9 will analyse the significance of the EU's international legal personality and how this evolving international identity of the Union is in want of a set of obligations relating to the EU's action vis-à-vis human rights and a regime for the Union's responsibility on the international scene. Chapter 10 explores whether it is possible for the EU to breach any international human rights law obligation. Yet responsibility for such a breach would require attribution, which will be the subject matter of Chapter 11. Chapter 12 assesses the interaction between EU policies and their implementation by a Member State and international human rights law. Chapter 13 will explore the potential application of remedies for violations of international law by international organisations, on the European Union for human rights violations. Chapter 14 examines the practical question of procedure: the accountability of the $E U$ before other international institutions in order to obtain a remedy for the human right violation.

The Conclusion will contain the findings of the core research question - as to the existence and effectiveness of a system of procedures and substantive remedies for the EU and its institutions in relation to human rights violations, along with the corresponding suggestions. 


\section{INTRODUCTION}

\section{A. Introducing the research question}

1. Europe and human rights

By the middle of the twentieth century, Europe was being rebuilt after years of bloodshed and terror which rooted back to centuries of historical hostilities, leading only to an incredible disrespect of human dignity, the loss of life and a merciless attack against diversity. After the Second World War, it had become evident to the entire world that humankind should not suffer of the same torments again - and for that reason human beings were expressly recognised to have legal rights. ${ }^{1}$ The Universal Declaration of Human Rights of 1948 is an example of this fundamental goal:

\section{"Article 1}

All human beings are born free and equal in dignity and rights. They are endowed with reason and conscience and should act towards one another in a spirit of brotherhood"

Beyond such global initiatives, significant efforts were also made in Europe for the preservation of peace and the achievement of prosperity. In 1949 the Council of Europe was founded and in 1950 its members signed the European Convention for the Protection of Human Rights and Fundamental Freedoms, which forms today, the cornerstone of protection of human rights in Europe.

Aside from the recognition of human rights, European states also looked for economic cooperation as a means of achieving peace. There was even discussion of unifying or federalising Europe. In the Schuman Declaration, ${ }^{2}$ the French Finance Minister called for cooperation and "economic development as a first step in the federation of Europe." In 1951, the Treaty of Paris established the European Coal and Steel Community and in 1957 the Treaties of

\footnotetext{
${ }^{1}$ Article 55, of the UN Charter states that one of the purposes of the UN is 'promoting and encouraging respect for human rights and for fundamental freedoms for all without distinction as to race, sex, language or religion'.

${ }^{2}$ R. Schuman, "Declaration of 9 May 1950", in European Parliament, Selection of Texts concerning Institutional Matters of the Community for 1950-1982, (Luxembourg, Office for Official Publications of the European Communities, 1982) 47.
} 
Rome established the European Economic Community and the European Atomic Energy Community, with the aim of economic cooperation. ${ }^{3}$

These Communities developed over the years with significant reforms - in 1986 the Single European Act declared a commitment to the establishment of a common internal market, in 1992 the Maastricht Treaty established the European Union based on three pillars. ${ }^{4}$ As of these developments, the Union started to take a different, supranational dimension. In 1999 the Treaty of Amsterdam notably introduced the Area of Security, Freedom and Justice and the Schengen Agreements providing for customs union, and police and judicial cooperation. In 2000, in line with this new identity of the Union as a supranational actor, the EU Charter of Fundamental Rights was introduced by virtue of which the Union committed itself to the rights contained therein along with the Nice Treaty. In 2009, the Lisbon Treaty established two founding treaties underpinning the Union's existence: the Treaty on the European Union, and the Treaty on the Functioning of the European Union, abolishing the three pillars, expanding the jurisdiction of the Court of Justice of the EU and making the Charter of Fundamental Rights of the EU binding.

Since the Schuman Declaration of 1950, the European Union has turned into a complex legal entity with competences expanding from the regulation of a common market to the formulation of a common foreign and defence policy.

This is why the current institutional framework of the Union deals with the Union's personality and obligations in a much different way as compared to its initial inception. Today, the European Union is an organisation with its own legal personality, ${ }^{5}$ founded on the respect for human rights $^{6}$ and bound to promote their protection. ${ }^{7}$

Where such a thorough commitment to human rights is declared, there ought to be a system within which the Union is held responsible for the violation of human rights it recognises in its Charter and the two founding Treaties. The existence of a legal personality ought to have as a

3 S. White, 'The Accession of the European Union to the European Convention of Human Rights' (2011) 86 Amicus Curiae 7, 8.

${ }^{4}$ The three pillars as per Article 3 of the Treaty on the European Union (1992) were: The European Community, the Common Foreign and Security Policy and Justice and Home Affairs.

${ }_{6}^{5}$ Article 47 TEU.

${ }^{6}$ Article 2 TEU.

${ }^{7}$ Article 3(5) TEU. 
consequence, that actions taken by the Union, trigger its legal responsibility. That is necessary in order for an individual to be able to obtain redress when her rights have been violated by the Union. Union law must offer a substantive standard of protection of human rights, through the procedures provided within it.

The strand of the efforts that began in the mid-twentieth century that led to the establishment of the EU, developed in parallel of other international treaties concerned with human rights such as the European Convention on Human Rights. The Council of Europe and the European Union have remained distinct over the decades of European integration, with the Union not having yet adhered to the Convention. In effect while the Council of Europe was working towards the goal of protecting the rights of the individual, particularly through the European Convention on Human Rights, ${ }^{8}$ the European Union remained focused on economic prosperity. Until today, it has not acceded to the Convention, nor any other international treaty which covers a wide spectrum of human rights. The relationship between the EU itself and international human rights law obligations that may bind it this remains unclear. Nevertheless, the EU's broad and diverse array of policies, acts and legislation inevitably interacts with the human rights of individuals who may be affected. This calls for the need to establish a system of redress for violations by the EU on the international sphere as well as the EU legal order.

2. Introducing the concept of responsibility and remedies for violations of human rights by the EU

The topic of this thesis is the process - and the challenges - of obtaining remedies for the violation of human rights by the European Union. In essence, the present thesis aims to answer the question of how the Union's legal responsibility for the violations may be engaged effectively, with the purpose of achieving the substantive remedying of the violation and the rectification of the harm suffered by the victim.

The questions of responsibility and remedies are therefore inextricably interwoven, in the sense that the ability to obtain a substantive remedy presupposes the successful establishment of responsibility before a legally established institution with a defined jurisdiction. Accordingly, the

${ }^{8}$ Council of Europe Manual of the Council of Europe. Its Structure, Functions and Achievements (Stevens, London 1970). 
successful engagement of responsibility has a diminished legal and real effect, if no meaningful substantive remedies are accessible or available for the victim who requires the vindication of her rights.

This thesis will examine the above theoretical premise by examining in depth the contexts in which the European Union may be held accountable for the violations of human rights and where the victims may invoke human rights obligations against the EU in order to obtain substantive and meaningful redress for the violation and the harm they have suffered.

The purpose is reaching a conclusion on this initial hypothesis: that the European Union lacks a coherent and effective system of legal protection, scrutiny and remedies for human rights violations committed by itself. This hypothesis is based on the fact that there is a remedies deficit for the violations of human rights by the EU.

The EU is not a party to any multilateral human rights treaty apart from the United Nations Convention on the Rights of Persons with Disabilities, therefore there is a lack of scrutiny within the framework of international human rights law. This means that the EU does not have a clear status of an addressee of human rights obligations at an international level, which incapacitates rights holders from invoking such obligations against the Union, in international fora. The EU's proposed accession to the European Convention of Human Rights as envisaged by Article 6(2) TEU seems to unlikely to be achieved, ${ }^{9}$ excluding the EU from effective human rights monitoring by international bodies.

Secondly, while judicial review, or the action for annulment of an EU act on the basis of illegality under Article 263 TFEU is in principle the best suited procedure for establishing the responsibility of the Union for violations of its human rights obligations under its Treaties and thus eradicating the unlawful act, it is a procedure of severely limited effectiveness. In judicial review procedures, the locus standi of individuals for acts not addressed to them is excruciatingly difficult to establish. ${ }^{10}$ The case law of the Court of Justice in effect places high

\footnotetext{
${ }^{9}$ The EU's proposed accession to the European Convention on Human Rights was halted by the CJEU's Opinion 2/13 EU:C:2014:2454.

${ }^{10}$ See Chapter 2 of this Thesis, and also Case 25/62 Plaumann \& Co v. Commission [1963] ECR I-2343, Case C309/89 Codorniu v. Council [1994] ECR I-1853, Case C-50/00P UPA v. Council [2002] ECR I-6677, Case T177/01 Jégo Quéré v. Commission [2002] ECR II-2365, Case 40/64, Sgarlata v Commission [1965] E.C.R. 215,
} 
thresholds for individuals invoking human rights claims, thus hindering rights' holders from effectively claiming their rights.

These gaps are partially rectified by other legal procedures and legal doctrines. The doctrine of direct effect in combination with the procedure of preliminary references may lead to the invalidation of acts that violate human rights, but indirectly through national courts and individuals themselves do not challenge the EU. This indirect nature also characterises the plea of illegality under Article 277 TFEU, which is pleaded within the framework of another procedure, thus being a dependent, non-autonomous procedure. Specialist bodies scrutinising specific areas of EU action, such as the EULEX panel only form a partial solution and not a holistic approach.

\section{B. The role of this thesis and the academic discourse on the EU and Human Rights}

1. The first milestone of this thesis: identification of the necessity of a system of remedies for the EU vis-à-vis human rights

The significance of this research lies in the fact that while the Union claims to abide by human rights, ${ }^{11}$ and also passes legislation and acts that aim at the protection of human rights at a Member State level, ${ }^{12}$ the legal regime for remedies for human rights violations by the EU is insufficient, while at the same time the Union's competences expand to areas where human rights protection is of crucial importance.

227, Case C-345/00, FNAB v Council [2001] E.C.R. I-3811 and A. Kornezov, 'Locus standi of private parties in actions for annulment: has the gap been closed?' (2014) 73(1) CLJ 25-28, at 25, A. Albors-Llorens, 'Sealing the fate of private parties in annulment proceedings?' The General Court and the new standing test in article 263(4) TFEU' (2012)71(1) CLJ, 52-55.

${ }^{11}$ Articles 2 and 3(5) TEU.

12 Very indicatively, see the European Union Charter on Fundamental Rights which obliges Member States to respect it while applying EU law, the Council Framework Decision 2008/977/JHA of 27 November 2008 on the protection of personal data processed in the framework of police and judicial cooperation in criminal matters, Directive 2002/58/EC of the European Parliament and of the Council of 12 July 2002 concerning the processing of personal data and the protection of privacy in the electronic communications sector, Council Directive 2004/38/EC of 29 April 2004 on the right of citizens of the Union and their family members to move and reside freely within the territory of the Member States, Council Directive 2000/78/EC of 27 November 2000 establishing a general framework for equal treatment in employment and occupation, Council Directive 2000/43/EC of 29 June 2000 implementing the principle of equal treatment between persons irrespective of racial or ethnic origin. 
Therefore, it appears that the status of the Union as an addressee of human rights obligations is incoherent, thus offering crippled protection to rights holders who may be influenced by its action and restricted access to remedies for the harm they suffered. This contradiction has been noticed and arguments have been made that the Union is not a human rights organisation ${ }^{13}$ and that the EU's commitment to human rights is only rhetoric. ${ }^{14}$

It is of utmost importance to understand where and why the need for effective remedies arises and why rights holders moving in the ambit of EU action require the EU to really be a human rights obligations addressee. The complexity of answering the research question begins with the fact that the EU, as an international organisation, has to find a role in the spectrum of human rights law. The jurisprudential and philosophical concept of human rights law comprises rights holders, who are the parties enjoying the right, and an object, which is the thing or idea protected by that right. ${ }^{15}$ Human rights philosophy also encompasses addressees, who are the parties directed to do or refrain from an activity, in order to protect the right. ${ }^{16}$

This legal concept must apply to the European Union, in a structure where the Union acts as the addressee bearing the human right obligation, protecting the right holders who are persons that may be affected by Union acts. The rights holders in the case of the EU are persons whose lives, professions and activities may be influenced by the policies laid down by the EU's institutions and executed by all of its offices, servants, bodies and agencies, even possibly entities that belong to Member States. ${ }^{17}$ As such, these authorities and entities may be, by extent the addressees of the human rights obligations and engage Union responsibility; through them takes effect the realisation of Union policy.

First and foremost, accountability must be provided by the legal system of the Union itself, through the mechanisms that EU law provides for individual claims against Union action. The case law regarding the action for annulment provided for by Article 263 TFEU is unfortunately a

\footnotetext{
13 A. Von Bogdandy, 'The European Union as Human Rights Organization: Human Rights and the Core of the European Union' (2000) 37 CMLRev 1307, Rosas A., 'Is the EU a Human Rights Organization?', CLEER Working Paper 2011/1.

14 A. Williams, The Irony of Human Rights in the European Union (OUP 2004).

${ }^{15}$ K. Nickel and D. Reidy, 'Chapter 2 - Philosophy' in D. Moeckli, S. Sivakumaran and S. Shah, International Human Rights Law (OUP 2010) 41.

${ }^{16}$ Ibid.

${ }^{17}$ See Chapter 11, on the matter of attribution.
} 
legal remedy of limited effectiveness for individuals who wish to hold EU institutions accountable for the violation of their rights through their acts. The standing requirements are so stringent that individual applicants have little luck bringing forward human rights claims and arguing in favour of contemporary human rights notions. An example is the case of Inuit, ${ }^{18}$ where an action for annulment was brought on the basis that a Regulation of trade in seal products was at odds with the fundamental rights of an indigenous tribe and the application was dismissed for lack of standing of the tribe who needed to prove 'direct and individual concern.'

Non-accession to the European Convention of Human Rights (ECHR) also means that the remedies available in that legal order are unavailable to the individual whose rights have been violated by the EU, despite the latter being an organisation set up by states who are all parties to the ECHR. The proposed accession of the EU to the European Convention on Human Rights as provided for by Article 6(2) TEU would be a way to ensure all areas of EU action could be examined vis-à-vis their compatibility with human rights. The procedure was halted by the Court of Justice of the European Union in Opinion 2/13, ${ }^{19}$ because the proposed Accession Agreement was deemed incompatible with EU autonomy, thus maintaining the absence of external control.

The establishment and existence of bodies and agencies such as, the European Anti - Fraud Office $(\mathrm{OLAF})^{20}$ which collects personal information, FRONTEX ${ }^{21}$ which controls the Union's external borders in an era where the numbers of refugees and migrants rise considerably, or the European Union Agency for Law Enforcement Cooperation (EUROPOL), ${ }^{22}$ also calls out for an

\footnotetext{
${ }^{18}$ Case T-18/10 Inuit Tapiriit Kanatami v European Parliament [2011] E.C.R. II-5599, C-398/13 P Inuit Tapiriit Kanatami v European Commission EU:C:2015:535.

${ }^{19}$ Opinion 2/13 of the Court of Justice of the European Union, EU:C:2014:2454.

${ }^{20}$ September 2013 amending Decision 1999/352/EC, ECSC, Euratom establishing the European Anti-fraud Office and Commission Decision (EU) 2015/512 of 25 March 2015 amending Decision 1999/352/EC, ECSC, Euratom establishing the European Anti-fraud Office, of which the powers for investigation are laid down in Regulation (EU, Euratom) No 883/2013 of the European Parliament and of the Council of 11 September 2013 concerning investigations conducted by the European Anti-Fraud Office (OLAF) and repealing Regulation (EC) No 1073/1999 of the European Parliament and of the Council and Council Regulation (Euratom) No 1074/1999.

${ }^{21}$ Regulation (EU) 2016/1624 of the European Parliament and of the Council of 14 September 2016 on the European Border and Coast Guard and amending Regulation (EU) 2016/399 of the European Parliament and of the Council and repealing Regulation (EC) No 863/2007 of the European Parliament and of the Council, Council Regulation (EC) No 2007/2004 and Council Decision 2005/267/EC (OJ L 251, 16.09. 2016, p. 1).

${ }^{22}$ Regulation (EU) 2016/794 of the European Parliament and of the Council of 11 May 2016 on the European Union Agency for Law Enforcement Cooperation (Europol) and replacing and repealing Council Decisions 2009/371/JHA, 2009/934/JHA, 2009/935/JHA, 2009/936/JHA and 2009/968/JHA.
} 
inclusive system of procedures and remedies before the EU's institutions, where individuals who may be influenced by the acts of such bodies or agencies are able to obtain redress.

It is useful therefore to explore the fruitfulness of another procedure in EU law, often disregarded in academic literature and legal practice, which could prove a useful vehicle in both the establishment of legal responsibility and the substantive remedying of the violation of a human right: the non-contractual liability procedure under Article 340(2) TFEU. This, as it will be seen in Part II of this thesis is not free of encumbrances, particularly in the judicial interpretation area. In Arcelor $^{23}$, a company brought a claim for damages on the basis that a directive on greenhouse gas emissions restricted disproportionately the substance of its right to property and its freedom to pursue an economic activity because it required the applicant to operate its plants under economic conditions which were unsustainable. It was found that the applicants had not proved a sufficiently serious breach and grave disregard in the exercise of the discretion of the Union institution.

Beyond the interpretative problems which reveal the need for improvement, expansion of EU policies also demonstrates the need for a coherent system of remedies for human rights violations before the EU courts. For example, matters of human rights have been raised in litigation against the Union for economy - related measures imposed on Member States which have an effect on individuals. ${ }^{24}$ In these cases, the EU legal system has also demonstrated a lack of coherence and consistency when facing two actions which related to the Union's human rights responsibility within the European Stability Mechanism. The CJEU found the Union susceptible to judicial scrutiny in an action for damages, and immune to a judicial review application. In Konstantinos Mallis, ${ }^{25}$ regarding the decision for the direct levy from individual bank accounts, the CJEU found the Union's action within the framework of the ESM not to be reviewable in light of the fact that the ESM is a different organisation and declared the action inadmissible. For the very

${ }^{23}$ Case T-16/04 Arcelor SA v. European Parliament and Council, 2 Mar 2010.

${ }^{24}$ Joined Cases C-8/15 P to C-10/15 P Ledra Advertising Ltd and Others v European Commission and European Central Bank (ECB) Judgment of the Court (Grand Chamber) of 20 September 2016 ECLI:EU:C:2016:701, Joined Cases C-105/15 P to C-109/15 P Konstantinos Mallis and Others v European Commission and European Central Bank (ECB) Judgment of the Court (Grand Chamber) of 20 September 2016 ECLI:EU:C:2016:702. The first case involved an action for damages against austerity measures imposed by the Union where the Court found the Union's action capable for engaging non-contractual liability and the second one an action for annulment where the Court found that the Union's action could not be subject to review.

${ }^{25}$ Ibid. 
same act, in Ledra Advertising, ${ }^{26}$ the CJEU decided that it could engage Union responsibility but rejected the action for damages on the basis that no violation of the right to property was found.

The inability to have access to the remedies of the ECHR also opens up another important question; the one of responsibility of the EU as an international organisation and therefore the obtention of remedies for violations of human rights within the sphere of public international law. To this end it is useful to examine the interplay between public international law and the $\mathrm{EU}$, the EU's role as an international non-state actor as well as the possible application of international responsibility rules and remedies to the $\mathrm{EU}$ on the matter of human rights violations. As the EU's international activity broadens with each passing day, and its international features become more accentuated, it is necessary to examine how the EU may have obligations on the basis of international law and what their violations may entail.

It is consequently imperative to examine all the above issues in a holistic manner, as a unitary topic, since they are interlinked. These matters all give rise to the same question: how the Union may be held directly responsible for violating human rights in any of its fields of action, both within the Union's legal and judicial system and at an international level, in order for the victim of the violation to be able to obtain the necessary substantive redress.

2. Addressing the question and substantially contributing to the academic discourse on the EU and human rights

To date, academic discourse on the relationship between EU and human rights has concentrated on the role of human rights as a part of the EU legal order. Academic discourse has often avoided to address directly the question of the enforcement of those human rights norms vis-àvis the EU.

The concept of a unitary human rights policy became a subject of discussion as early as 1979 with the European Commission arguing that the EU should accede to the European Convention on Human Rights, ${ }^{27}$ while by the 1990 s the matter of a unitary human rights policy became a

\footnotetext{
${ }^{26}$ cf. Ledra Advertising (n.24).

${ }^{27}$ Commission of the European Communities 'Memorandum on the Accession of the European Communities to the Convention for the Protection of Human Rights and Fundamental Freedoms’ Bulletin Supplement.
} 
significant legal question for the growing Union, ${ }^{28}$ and it was strongly argued that the EU should acquire a human rights policy. ${ }^{29}$

A fundamental reform that was brought about was the introduction of the EU Charter of Fundamental Rights in 2000 and its binding force acquired following the Lisbon Treaty in 2009. Furthermore, Article 6(2) of the Treaty on the European Union today provides that the Union is obliged to accede to the European Convention on Human Rights. These developments are well known to scholars of EU law.

Along these developments in EU law, academic discussion on the protection of human rights within Union law also increased. Indeed, numerous pieces of academic writing have discussed the role of human rights law within EU law albeit in an abstract and fragmentised manner, with many references made to the Charter of Fundamental Rights, the incorporation of human rights law through the case law of the Court of Justice of the European Union and the inspiration drawn by the latter from the European Convention on Human Rights. ${ }^{30}$ Indeed, many academic writings have been devoted to the interaction between the Court of Justice of the Union and the European Court of Human Rights. ${ }^{31}$

${ }^{28}$ Opinion 2/94 Accession by the Community to the European Convention for the Protection of Human Rights and Fundamental Freedoms [1996] ECR I-1759.

${ }^{29}$ See A. Clapham, 'A Human Rights Policy for the European Community' (1990) Yearbook of European Law, 309, P. Alston and J.H.H. Weiler, 'The European Union and Human Rights: Final Project Report on an Agenda for the Year 2000', A. Cassese (ed) Leading by Example: A Human Rights Agenda for the European Union of the Year 2000 (Florence, European University Institute 1998) P. Alston (ed), The EU and Human Rights (Oxford University Press 1999).

${ }^{30}$ S. de Vries, U. Bernitz and S. Weatherill (eds), The Protection of Fundamental Rights in the EU after Lisbon (Hart Publishing 2013), S. Morano - Foadi and L. Vickers, Fundamental Rights in the EU - A matter of two courts (Hart 2015) G. di Federico (ed), The EU Charter of Fundamental Rights. From declaration to Binding Document (Dordrecht, Springer Netherlands 2011), S. Douglas Scott, 'A Tale of Two Courts: Luxembourg, Strasbourg and the Growing Human Rights Acquis' (2006) 43 CMLRev 629, J. Wetzel (ed), The EU as a 'Global Player' in Human Rights? (New York, Routledge, 2011), S. Iglesias Sanchez, 'The Court and the Charter: the Impact of the Entry into Force of the Lisbon Treaty on the ECJ's Approach to Fundamental Rights' (2012) 49 CMLRev 1565, S. Douglas Scott, 'The European Union and Human Rights after the Treaty of Lisbon'(2011) HRLR 1, P. Craig, 'The Financial Crisis, the EU Institutional Order and Constitutional Responsibility' in F. Fabbrini, E. Hirsch Ballin and H. Somsen (eds), What Form of Government for the European Union and the Eurozone? (Hart 2015), S. Peers, T. Hervey, J. Kenner and A. Ward, (eds), The EU Charter of Fundamental Rights, A Commentary (Hart Publishing 2014), C. Lebeck, 'The European Court of Human Rights on the Relation between ECHR and EC-Law: The Limits of Constitutionalisation of Public International Law' (2007) 62 Zeitschrift fur öffentliches Recht 195, C. Barnard, "The EU Charter of Fundamental Rights: Happy $10^{\text {th }}$ Birthday?" <http://www.law.cam.ac.uk/facultyresources/download/the-eu-charter-of-fundamental-rights-happy-10th-birthday/8348/pdf.> .

${ }^{31}$ Indicatively S. Douglas Scott, 'A Tale of Two Courts: Luxembourg, Strasbourg and the Growing Human Rights Acquis' (2006) 43 CMLRev 629, D. Simon, 'Des influences réciproques entre CJCE et CEDH: Je t'aime, moi non 
Certain commentators have looked at particular or specific aspects of EU accountability vis-à-vis human rights law. Such aspects include the Union's external action and its relationship with international human rights law. ${ }^{32}$ These writings have pointed out the unclear legal framework that surrounds the Union's activity as a global actor, and their role in expressing the need for a system of remedies at an international level is significant.

Over the years, numerous publications have also dealt with the EU's proposed accountability before the European Court of Human Rights through the potential accession of the EU to the European Convention on Human Rights. ${ }^{33}$ To a great extent, these significant contributions have analysed the effects of a potential accession and have critically assessed the proposed provisions for the EU's accountability before the European Court of Human Rights.

This thesis is not a general analysis of how human rights law has permeated the fabric of European Union law. It will not discuss the positive and negative aspects of a potential Accession of the EU to the European Convention on Human Rights. Neither will this research pick and choose to analyse specific areas of EU action where human rights violations may occur.

plus!' (2001) Pouvoirs 31, S. Morano - Foadi, 'Fundamental Rights in Europe: “Constitutional” Dialogue between the Court of Justice of the EU and the European Court of Human Rights' (2013) 5(1) Onati Journal of Emergent Socio-Legal Studies 64.

${ }^{32}$ B. van Vooren and R.A. Wessel, EU External Relations Law, Text, Cases and Materials (CUP 2014), Eeckhout P., U External Relations Law, (2 ${ }^{\text {nd }}$ edn, OUP 2011), P.J. Kuijper, 'The European Courts and the Law of Treaties: the Continuing Story' in E. Cannizzaro, (ed) The Law of Treaties beyond the Vienna Convention (OUP 2011), G. de Búrca, 'The Road not taken: The European Union as Global Human Rights Actor' (2011) 105 AJIL 649, F. Naert, International Law Aspects of the EU's Security and Defence Policy (Intersentia 2010), E. Papastavridis, 'EUNAVFOR Operation Atlanta off Somalia: the EU in unchartered legal waters?' (2015) 64(3) ICLQ 533-568, F. Hoffmeister, 'Litigating against the European Union and its Member States - who responds under the ILC's Draft Articles on international responsibility of international organizations?' (2010) 21(1) EJIL 723-747, A. Sari and R.A. Wessel (eds), Human Rights in EU Crisis Management Operations: A Duty to Respect and to Protect? (The Hague: CLEER Working Paper Series 2012/6). G. de Búrca, 'The European Court of Justice and the International Legal Order After Kadi', (2009) 51(1) Harv ILJ 1, 29, B. van Vooren, 'A Legal Institutional Perspective on the European External Action Service' (2011) 48 CMLRev 475-502.

${ }^{33}$ P. Craig, 'EU Accession to the ECHR: Competence, Procedure and Substance' (2013) 36 Fordham International Law Journal 1115, S.O. Johansen, 'The Reinterpretation of TFEU Article 344 in Opinion 2/13 and Its Potential Consequences [comments]' 16 German L.J. 169 (2015) 169-178, P. Gragl, 'Beyond Bosphorus: The European Court of Human Rights' Case law on the Responsibility of Member States of International Organisations under the European Convention on Human Rights' (2010) 10 HRLR 529, T. Lock, 'EU Accession to the ECHR: Implications For Judicial Review in Strasbourg' (2010) 35 ELR 777, B. de Witte and S. Imamovic, 'Opinion 2/13 on accession to the ECHR: defending the EU legal order against a foreign human rights court' (2015) ELR, 695 - 697, T. Lock, 'The ECJ and the ECtHR: the Future Relationship between the Two European Courts' (2009) 8 The Law and Practice of International Courts and Tribunals 375, T. Lock, 'Walking on a Tightrope: 'the Draft Accession Agreement and the Autonomy of the EU Legal Order' (2011) 48 CMLRev 1025, J.P. Jacqué, 'The Accession of the European Union to the European Convention on Human Rights and Fundamental Freedoms' (2011) 48 CMLRev 995. 
This thesis will take a deeper and at the same time more practical approach to the matter of accountability of EU law in relation to its human rights obligations. In particular, this research project will seek to comprehend how the EU may be held accountable for violations of human rights through procedures and remedies available to the individual who wishes to claim her rights against EU institutions. This thesis will scrutinise not only the interpretations of the Court of Justice of the European Union in human rights related cases but also the procedural aspects and obstacles of bringing a claim for human rights violations against the Union. This will not only lead to a deeper understanding of how human rights may be protected but also move further than the theoretical and academic context by providing an analysis of practical aspects of EU procedural law at the same time bringing forward important questions as to the extent that human rights obligations for the EU may be enforceable.

The research conducted in the area of non-contractual liability of the Union aims to contribute substantially in this area of EU law, on which both the case law and the literature are not as ample as in the area of judicial review and preliminary references. What is more, this Thesis adds further light to the usefulness and value of Article 340 TFEU - it demonstrates its relevance to the protection of human rights. It reminds that human rights claims are not only claims of vindication, declaration or acknowledgment but also claims following damage that has occurred. This forms the core of Part II of the present Thesis.

Similarly, Part III of the Thesis explores another legal area which is in need of attention: that is the accountability of the European Union as an international organisation, that is as a non-state, international actor. The status of non-state entities in international law is incoherent and these areas of law requires further development. Yet, the need of remedies persists and international law ought to contribute this, given that it is, par excellence, the legal system which advocates the protection of the individual's rights and her dignity. This thesis therefore not only explores this area but even more importantly, it points out the problems and voids left.

By analysing these procedures and remedies, this thesis will sketch the outline of a general system of EU accountability for human rights violations. These aspects will be explored through examples and cases that have arisen in relation to the EU's accountability for human rights, but by also making hypotheses as to potential challenges that will arise. Through this analysis, this 
research will seek to draw conclusions as to the effectiveness of legal and substantive remedies against the EU in relation to human rights, point out any deficiencies and propose developments that may be necessary for an effective regime of accountability.

The necessity for understanding how all Union acts, of internal or external effect, of a legislative, executive, implementing or enforcing nature, may engage Union responsibility and how the damage they cause may be remedied, is not merely of an academic or theoretical nature. It is imperative for the individual who is subject to Union action to comprehend her rights under European Union law and international law and the limits within which the Union must act. It is also important to understand the procedural and practical aspects of engaging the Union's responsibility.

By taking this pragmatic approach to the question of EU responsibility vis-a-vis human rights, this research project aspires to be, apart from a contribution to the academic discourse surrounding the relationship between the EU and human rights, a detailed and informed handbook for the individual or the advocate who in effect encounters the difficult challenge of bringing a claim against an EU organ for violating human rights.

\section{Terminology - human and fundamental rights}

The overarching theme in this thesis the protection of human rights. The theoretical premise of human rights is complex and its origins can be traced to concepts of legal theory and jurisprudence that have existed for millennia. It is important on that basis, to explain the rightsrelated terminology to be used in this thesis.

The terms 'fundamental rights', 'human rights' will be used interchangeably, depending on the context of discussion. The term 'fundamental rights' is a broad concept which has been developing for centuries and encompasses rights that are awarded not only to individuals but also to legal entities. The term itself arose as early as the seventeenth century, following the Treaty of Westphalia, with important scholars such as Grotius, Martens and de Vattel bringing forward the idea that fundamental rights must be guaranteed for moral persons, meaning natural individuals who abide by the laws of morality also known as natural law, and also collective entities such as 
states. These ideas were strongly influenced by the doctrine of natural law, which was a source of regulating both individual-state relations as well as inter-individual relations. ${ }^{34}$

These rights included equality, security and the freedom to conduct commerce. ${ }^{35}$ This notion may be seen as a precursor of human rights since it is a broader term which deals with a greater range of freedoms that are enjoyed by individuals and legal personalities alike, and that do not necessarily have at their core the protection of the human being. In the same spirit, the CJEU's case law introduced the concept of 'fundamental rights' ${ }^{36}$ in light of the fact that EU was more concerned with economic freedoms of entities and states rather than human dignity and the individual. Similarly, the Charter of Fundamental Rights of the European Union uses the term 'fundamental rights' as many of its provisions are not only aimed at the safeguarding of human dignity but also the freedoms of legal entities and the rights of the individual in relation to economic activities. ${ }^{37}$

The idea that individuals should be protected against arbitrary state action is also very old, perhaps the first concrete example being the Magna Carta of 1215. The theory also surfaced in the seventeenth century, when Locke stated that rulers should have as their priority the protection of their subjects. ${ }^{38}$ Subsequent significant expressions of such values, are the US Declaration of Independence of 1776 and the French Declaration of the Rights of Man of 1789. Nevertheless, the term 'human rights' arose at a later stage compared to fundamental rights. As it has been explained in the beginning of this introductory chapter, the need for protecting human dignity began becoming more imperative in the twentieth century, following the atrocities of the two World Wars. Indeed, human dignity is the cornerstone of the legal and ideological concept of human rights today ${ }^{39}$ and its protection features as the key objective in the Universal Declaration of Human Rights.

\footnotetext{
${ }^{34}$ S.M. Carbone and L. Schiano di Pepe, 'States, Fundamental Rights and Duties', (January 2009) MPEPIL. 35 Ibid.

${ }^{36}$ Case 11/70, Internationale Handelsgesellschaft v Einfuhr - und Vorratsstelle für Getreide und Futtermittel [1970] ECR 1125., Case 4/73, Nold v Commission [1974] ECR 491., Case 36/75, Rutili v Ministre de l'Intérieur, [1975] ECR 1219.

${ }^{37}$ See indicatively Article 13 on the freedom of the arts and sciences, Article 16 to conduct a business, Article 28 on the right of collective bargaining and action, Article 36 on access to services of general economic interest.

${ }^{38}$ J. Locke, Two Treatises of Government (1689).

${ }^{39}$ P. Nielsen, 'Human Dignity, International Protection', (October 2012) MPEPIL.
} 
The two terms have a great overlap. The EU Charter on Fundamental Rights corresponds to a significant extent, to the content of international human rights instruments as the European Convention on Human Rights. The term 'fundamental rights' will be used in reference to rights as recognised and developed in European Union law. ${ }^{40}$ The term 'human rights' will be used in reference to human rights norms and concepts within international law. Occasionally the single words 'right' or 'rights' will also be used in order to encompass both the concept of fundamental rights as developed in EU law and the more universal concept of human rights.

\section{Plan and Structure of this Thesis}

The objective of the first Part of this Thesis is to set forward and elaborate the hypothesis; that is that there is a significant deficit in the access to remedies for human rights violations that are committed by the EU. To this end, the first Chapter of Part I will analyse the complications that persist following the non-fulfilment of the EU's accession to the European Convention on Human Rights. Chapter 2 of Part I will be concerned with another significant legal problem in EU law which makes the remedies deficit more poignant; the limited effectiveness of the procedure of judicial review within EU law. Chapter 3 shall therefore delve into certain legal alternatives that may function as mechanisms for the attainment of remedies for violations of human rights; the doctrine of direct effect, preliminary references, the plea of illegality and the establishment of specialist bodies that examine complaints for specialised organs of the EU.

In light of the findings on the issue of the remedies' deficit, the Thesis will then turn to other potential routes and theoretical methods of obtaining remedies against the EU for human rights violations. The second Part will, for that purpose, research the interplay between human rights protection and the remedy provided by the principle of non-contractual liability as embodied in Article 340(2) TFEU. Chapter 4 will introduce and explain as a preliminary point the relationship between non-contractual liability and human rights issues. Then the criteria for the establishment of non-contractual liability will be examined vis-à-vis human rights cases. Those criteria are unlawfulness (Chapter 5) damage and causation (Chapter 6). The discussion on unlawfulness, damage and causation will be elaborated while concentrating on the application of

${ }^{40}$ See P. Gragl, The Accession of the European Union to the European Convention on Human Rights (Hart 2013) 12. 
these legal notions on human rights claims. For example, how finding unlawfulness in a human rights claim may have its specific interpretative rules or to what extent the violation of a human right constitutes a remediable damage per se to the point where even causation becomes redundant. This discussion will also include comparisons with national law and the jurisprudence of the ECtHR. The subject matter of Chapter 7 will be the relationship between the doctrine of non-contractual liability for lawful acts of the Union and human rights. Chapter 8 will assess the material scope of application of the principle of non-contractual liability and how this relates to the remedy's effectiveness for human rights violations.

The third Part of the thesis will explore the Union's obligations and accountability in general international law, with particular reference to the Articles on the Responsibility of International Organisations, customary law and jus cogens. Part III of the thesis will explore the external, international accountability of the Union in relation to human rights violations. It will delve into whether the Union may be held accountable for human rights violations in other international legal fora. This also requires an analysis of the remedies that are theoretically available within international law for such violations. This level of accountability is even less coherent and unchartered compared to the internal procedures of engaging Union responsibility within its own legal and judicial system. This is due to the lack of binding international human rights obligations of the Union in international law and the fact that the Union, despite its legal personality, ${ }^{41}$ as a global actor cannot be brought before other international tribunals that adjudicate the application of international human rights law. ${ }^{42}$ Chapter 9 will analyse precisely the significance of the EU's international legal personality and how this evolving international identity of the Union is in want of a set of obligations relating to the EU's action vis-à-vis human rights and a regime for the Union's responsibility on the international scene. Chapter 10 will be concerned with whether the EU can in theory breach any international human rights law obligation. Yet responsibility for such a breach would require attribution, which will be the subject matter of Chapter 11. Apart from acts within the framework of its foreign policy, it is also important to assess the interaction between EU policies and their implementation by a

\footnotetext{
${ }^{41}$ Article 47 TEU

${ }^{42}$ The EU is not a party to the European Convention on Human Rights (See Chapter 4), the International Covenant on Civil and Political Rights or the International Covenant on Social, Economic and Cultural Rights (See Chapter 3), while as a non-state actor it cannot be brought before the International Court of Justice for the purposes of breaching jus cogens.
} 
Member State in light of international human rights law, in Chapter 12. Given that the subject of remedies for human rights violations by the Union is the central research question of this Thesis, Chapter 13 of this Part will explore the potential application of remedies for violations of international law by international organisations, on the European Union. Chapter 14 will look at the final, practical question of procedure: the accountability of the EU before other international institutions which will be the vehicle for the obtaining of a legal or other remedy for the human right violation.

The Conclusion will contain the findings of the core research question - as to the existence and effectiveness of a system of procedures and remedies for the EU and its institutions in relation to human rights violations. These findings will be accompanied by suggestions as to the establishment of a sound and coherent regime whereby the Union will be truly bound and accountable and be required to remedy the harmed caused in cases where its conduct violates human rights. 



\section{Part I - The remedies deficit}

This Thesis has as its core research question the availability of substantive remedies for individual applicants, relating to breaches of fundamental and human rights by EU institutions. The basis of the hypothesis is that the substantive remedies available to individuals for human rights violations by the European Union are limited and ineffective, due to procedural obstacles.

This first Part, is dedicated to the explanation and analysis of this significant deficit in the protection of human rights within the espace juridique of the EU, by examining certain crucial and persistent juridical issues that give rise to the hypothesis of this thesis.

First and foremost, there is the notable absence of individual access to the remedies offered by the European Court of Human Rights (just satisfaction, general measures, restitution by the respondent state) as a result of the non - accession of EU to the European Convention of Human Rights. In essence, the lack of accession creates a deficit by hindering international human rights law and doctrine to effectively infiltrate internal EU law through the bindingness of ECtHR judgments. Furthermore, it means that it is impossible for individuals to hold the EU accountable before the most effective system of human rights protection and obtain the remedies to the violations of their rights, offered by this system. This will form the discussion of Chapter 1.

As a result of the lack of the scrutiny and the remedies provided for by the ECHR one has to turn to remedies provided by the EU legal system itself. The best suited procedure for the recognition of the violation of a person's rights is the action for annulment as provided by Article 263 TFEU. It is a direct attack by the individual applicant on the violating act which, if successful, means that the act is eradicated and its application is consequently suspended. This remedy is difficult to obtain. The standing criteria for individuals under this procedure are stringent. The scope of the CJEU's jurisdiction and the areas of EU action in which an individual may claim annulment are unclear. These factors constitute this remedy ineffective and not readily accessible to the victim of the human rights violation. This will form the discussion of Chapter 2.

Chapter 3 will examine certain 'alternatives' to the gaps left by the absence of accessibility to the remedies mentioned above. Firstly, the doctrine of direct effect, in combination with the procedure of preliminary references may lead to the invalidation of acts that violate human 
rights, although in an indirect fashion. This means that the individuals themselves do not challenge the EU directly on the basis of these rules. This indirect nature also characterises the plea of illegality under Article 277 TFEU. Finally, the gaps in the jurisdiction of the CJEU may be partially filled by creating specialist bodies scrutinising acts in specific areas of EU action, yet again this is a partial solution. 


\section{Chapter 1}

\section{The failure of EU Accession to the ECHR and the remedies deficit}

\section{A. Introduction}

This Chapter will explore how the development of the role of the ECHR in EU law has given rise to the necessity of establishing a system of effective remedies for human rights violations by EU institutions both within the EU legal system and beyond. This focuses on the need for accessibility to the ECHR remedies vis-à-vis Union acts.

EU law has developed historically to establish the ECHR as a standard of accountability for EU institutions for the protection of human rights (Section B) and afford it a constitutional status. However, while this standard of accountability exists, there is no formal way for the ECHR remedies to be available for human rights violations caused by EU institutions, with consequences on the ability of victims of human rights violations to effectively claim their rights (Sections C and D). It is therefore deduced that the historical relationship between EU law and the ECHR has developed to the point that the substantive remedies provided by the Convention are required for human rights violations by EU institutions, yet non-accession proves to be a thorn in establishing a coherent system of remedies for violations of human rights by the EU itself.

\section{B. The history of the ECHR in EU law}

The first attempt to establish a relationship between the EU and the ECHR was the 1952 European Political Community Treaty, which would have made the Convention part of Community law, but it was not adopted. The EU's respect for human rights and the ECHR developed instead through the "general principles" of EU law: rules and values developed by the ECJ which underpin EU law and guide its interpretation. ${ }^{1}$

\footnotetext{
${ }^{1}$ M. Horspool and M. Humphreys, European Union Law (6 $6^{\text {th }}$ edn OUP 2010) 136, 141.
} 
In 1965 the European Commission's President argued in favour of fundamental rights included in these general principles. $^{2}$ In Internationale Handelsgesellschaft ${ }^{3}$ the ECJ admitted that fundamental rights form an integral part of EU law. But this was not deemed sufficient protection of human rights within the legal order of the Union. In Solange the German Constitutional Court provided that as long as the Communities had no catalogue of human rights, the national courts should retain the power to review community acts as to their compatibility with human rights. ${ }^{4}$ This was the first demand for a human rights policy in the EU.

In time, the EU judiciary began to introduce the Convention to EU law. In Nold ${ }^{5}$ the ECJ held that international human rights instruments, including the ECHR and common constitutional traditions of the Member States were the two sources of inspiration of the general principles. In Rutili $^{6}$ the Convention was expressly mentioned as a source of rights invokable in EU courts. The CJEU repeatedly stated that the Convention had a 'special significance' within EU law. ${ }^{7}$

Article F of the Treaty on the European Union of 1992, stated that the Union should respect fundamental rights as guaranteed by the European Convention on Human Rights. However, even though the EU claimed to be a defender of fundamental rights, there was no holistic human rights policy in the EU. ${ }^{8}$ A substantial step towards such a policy was the EU's Charter of Fundamental Rights. Proclaimed in 2000, it is a codification of civil, political as well as social and cultural rights, ${ }^{9}$ which were already protected in the CJEU's jurisprudence. However, the Charter had no binding legal force. It was with the Lisbon Treaty that a breakthrough for the EU's commitment to human rights was made. Today, Article 2 TEU states that one of the founding values of the EU is human rights. Article 6(1) TEU gives the Charter the same binding force as the Treaties.

\footnotetext{
${ }^{2}$ See Remarks of Walter Hallstein, Eur. Parl. Deb, (79) (French edition) 17 June 1965) § 218-222.

${ }^{3}$ Case 11/70, Internationale Handelsgesellschaft v Einfuhr - und Vorratsstelle für Getreide und Futtermittel [1970] ECR 1125.

${ }^{4}$ Solange I BervfGE 37, 271 of 29.05.1974.

${ }^{5}$ Case 4/73, Nold v Commission [1974] ECR 491.

${ }^{6}$ Case 36/75, Rutili v Ministre de l'Intérieur, [1975] ECR 1219.

7 Cases C-402/05 and 415/05, P Yassin Abdullah Kadi and Al Barakaat International Foundation $v$ Council and Commission [2008] ECR I-6351.

8 P. Alston and J.H.H. Weiler, 'An 'Ever Closer Union' in Need of a Human Rights Policy: The European Union and Human Rights' in P. Alston (ed) The EU and Human Rights, (OUP 1999) 1.

9 C. Barnard, 'The EU Charter of Fundamental Rights: Happy $10^{\text {th }}$ Birthday?' < http://www.law.cam.ac.uk/facultyresources/download/the-eu-charter-of-fundamental-rights-happy-10th-birthday/8348/pdf.>
} 
The fact that the ECHR has served, and continues to serve as an indirect standard of human rights protection, becomes evident in the wording of the Charter. First, the role of the Charter is to bind the Union and the Member States when applying EU law, according to Article 51 of the Charter. Therefore, it functions as a standard of legality, violations of which may be invoked for judicial review procedures, preliminary references as well as for claiming damages against the Union. Article 52(3) of the Charter mentions that the rights contained in the Charter, which correspond to rights contained in the ECHR, have the same scope as the ones contained in the ECHR.

The ECHR plays a role in forming the scope of Charter rights, which in turn are expressly binding upon EU institutions. Article 53 of the Charter is also of importance, as it provides that the Charter should not be interpreted in way restrictive to the protection of rights protected by the ECHR. This provision effectively establishes that the interpretation of Charter rights is conditional upon the ECHR's provisions. This explains the academic commentary, from the initial introduction of the Charter, which identified the potential 'threat' that the Charter could have posed to EU law supremacy. ${ }^{10}$ In the case of multiple provisions of protection of human rights the Convention standard will prevail, while the general principles will never be interpreted in a way to contradict the Convention. ${ }^{11}$ Indeed, in Melloni, ${ }^{12}$ the Court referred to the jurisprudence of the ECtHR as a standard: if an EU measure is compatible with the interpretation of a right given by the ECtHR then the EU measure is deemed compliant with human rights.

The Convention has been invoked many times in cases before the CJEU, as in Kadi, ${ }^{13}$ where the Court recognised its role as a source of human rights obligations for EU institutions. After the binding nature afforded to the Charter after 2009, the Convention continues to be invoked before

\footnotetext{
${ }^{10}$ J. Bering Liisberg , 'Does the EU Charter of Fundamental Rights Threaten the Supremacy of Community Law?', (2001) 38 CMLRev 1171, L.F.M. Besselink, 'The Member States, the National Constitutions and the Scope of the Charter', (2001) 8 Maastricht Journal of European and Comparative Law 68, R. Alonso García, 'The General Provisions of the Charter of Fundamental Rights of the European Union', (2002) 8 ELJ 492, M. Pérez de Nanclares, 'Artículo 53', in A. Mangas Martín A (ed.), Carta de los Derechos Fundamentales de la Unión EuropeaComentario artículo por artículo (Fundación BBVA 2008).

${ }^{11} \mathrm{~W}$. Weiss , 'Human rights in the EU: rethinking the role of the European Convention on Human Rights after Lisbon’ (2011) 7(1) ECLR 64-95, 72.

${ }^{12}$ Case C-399/11 Melloni v Ministerio Fiscal EU:C:2013:107, para 50.

${ }^{13}$ Cases C-402/05 and 415/05, P Yassin Abdullah Kadi and Al Barakaat International Foundation $v$ Council and Commission [2008] ECR I-6351.
} 
the CJEU; an example is Ledra Advertising ${ }^{14}$ where Article 1 Protocol 1 to the ECHR protecting the right to property was invoked in parallel to the corresponding Article 17 of the Charter in an action for damages procedure.

Hierarchically the ECHR now has the value of a general principle of EU law, along with the Treaties and the EU Charter of Fundamental Rights. The EU has, instead of a constitution, the two Treaties that form the foundation of the entirety of its existence and legal system. On par with the Treaties and the Charter, there are general principles which must not be violated by any act of the European Union. These principles may be seen as 'interpretative aids' for Treaty provisions. ${ }^{15}$ The substance of these principles has been developed over the years by the Court of Justice of the European Union and its case law. Article 19 TEU states that the Court of Justice has the task of ensuring that the interpretation and application of the Treaties is duly observed by the EU institutions and the Member States.

This allowed the Court to elaborate a system of general principles for reviewing the legality of the Union's acts. ${ }^{16}$ They can be found spread across several articles of the Treaties and in the CJEU's case law. They include Proportionality, Fundamental rights, Legal Certainty, Legitimate Expectations, Equality, the Precautionary Principle, and Procedural Justice.

After primary law and the general principles come the legislative acts. ${ }^{17}$ As it has been explained above, these acts should be in pursuance of one of the aims set out in one of the Treaty provisions, and should be in the spirit of the general principles. Below the legislative acts we find delegated acts. ${ }^{18}$ Finally there are the implementing acts of the Commission to create homogeneous conditions for the application of legislative acts by the Union's member states.

To date, the rights included in the Convention are part of the 'general principles' of EU law, and are also included in the EU Charter of Fundamental Rights which is a part of primary EU law.

\footnotetext{
${ }^{14}$ Joined Cases C-8/15 P to C-10/15 P Ledra Advertising Ltd and Others v. European Commission and European Central Bank ECLI:EU:C:2016:701.

${ }^{15}$ P. Craig and G. de Búrca, EU Law Texts Cases and Materials (6 $6^{\text {th }}$ edn, OUP 2015) 551.

${ }^{16}$ Ibid.

${ }^{17}$ According to Article 289 TFEU, a legislative act may be a Regulation, a Directive or a Decision adopted jointly by the European Parliament and the Council of the European Union.

${ }^{18}$ According to Article 290 TFEU such acts are measures passed by the Commission if a legislative act provides for such a passage and delegates the power to the Commission, defining the objective, scope content and duration of the delegation.
} 
Today Article 6(3) TEU provides that fundamental rights as guaranteed by the European Convention for the Protection of Human Rights and Fundamental Freedoms, and as they result from the constitutional traditions common to the Member States shall constitute general principle of the Union's law.

The CJEU stated expressly that it has no jurisdiction to apply the ECHR directly. ${ }^{19}$ This means that the CJEU can in fact apply the Convention and interpret it in a flexible way ${ }^{20}$ which would serve the effet utile principle. $^{21}$ The CJEU has made many references to ECtHR case law and has even used the phrase 'as interpreted by the European Court of Human Rights', ${ }^{22}$ which has been characterised as 'borrowing towards appropriation'. ${ }^{23}$ The CJEU itself stated that the Convention expresses the nucleus of constitutionalisation of human rights in Europe. ${ }^{24}$ The CJEU should not only give weight to the decisions of the ECtHR but also implement the relevant ECtHR case law in order to attain the uniform protection of human rights in Europe. ${ }^{25}$

The reality is that the ECtHR's interpretation is authoritative upon the CJEU, ${ }^{26}$ while if the ECHR is to prevail in a case of a multitude of human rights protection systems in Europe ${ }^{27}$ its supremacy is substantially accepted. Uniform protection will be attained by the EU itself simply by complying with judgments of the ECtHR thereby affording the Convention a role of the highest level of norms by which all institutions in the EU - and potentially Europe - should abide. This in effect awards the ECHR a constitutional standing within the EU legal order.

The ECHR therefore possesses a high normative status within EU law, generating obligations for the EU institutions, yet indirectly. The question remains how individuals harmed by the EU's

${ }^{19}$ Case T - 347/94 Mayr - Melnhof v. Commission [1998] ECR II - 1751M $\$ \$ 9$ and 311, Case T-112/98 Mannesmannrohren -Werke v. Commission [2001] ECR II- 729, §59, Case T-99/04 AC - Treuhand AG v. Commission [2008] ECR - II 1501, §45.

20 J. Kühling, 'Grundrechte' in von Bogdandy A and Bast J., (eds) Europäisches Verfassungsrecht (Berlin Heidelberg, Springer 2009) 663.

${ }^{21}$ E. Klein, 'Das Verhaltins des Europäischen Gerichtshofs zum Gerichtshof fur Menschenrechte' in Mertin D. and Papier J (eds) Handbuch der Grundrechte in Deutschland und Europa, Band VI/1 Europäische Grundrechte I (Heidelberg, CG Muller 2010) 1276.

22 Case C-105/03 Criminal Proceedings against Maria Pupino [2005] ECR I - 5285, §60.

${ }^{23}$ D. Simon, 'Des influences réciproques entre CJCE et CEDH: Je t'aime, moi non plus!' (2001) Pouvoirs $31,37$.

24 Joined Cases 46/87 \& 227/88, Hoechst [1989] ECR 2859, §13.

25 Ibid.

26 cf. Weiss 'Human rights in the EU: rethinking the role of the European Convention on Human Rights after Lisbon' (n.11) 83-84, see also R. Alonso Garcia, 'The General Provisions of the Charter of Fundamental Rights of the EU', (2002) ELJ 493.

27 Ibid, Weiss. 
non-compliance with these obligations may obtain remedies for the violation of their rights. By extent, one has to examine how the judgments of the ECtHR could in fact compel the EU to rectify human rights violations for which it is responsible.

There is no formal way to allow potential victims to access ECHR remedies for the violations of the rights occurring from Union action. The only way of doing so would be the EU's accession to the ECHR, a concept which was growing gradually with the jurisprudential developments and legislative reforms described above. For this reason, Article 6(2) TEU today provides that the EU will accede to the ECHR. However, this provision has not so far been fulfilled.

Consequently, there remains a fundamental gap and deficit; the lack of formalisation of the status of the ECHR vis-à-vis EU law, not only as a standard of accountability but even more importantly as a system of remedies available for redress by the victim of human rights violations by the EU. The deficit left by the failed accession is only accentuated by the fact that, while the ECHR is afforded an effectively constitutional value within the Union's legal order, the remedies provided for by the Convention are unavailable to potential applicants wishing to challenge a Union deed which they believe violates their rights.

Accession to the ECHR would allow individual applicants bringing cases against the EU before the ECtHR and provide the opportunity to obtain substantive redress for the violations they have suffered. The objective of the Accession was to submit the EU to the external control of the ECtHR to ensure full accountability of the EU for Convention violations, including access to the remedies provided by the Strasbourg system. Following accession, the EU would have a status equal to any other party to the ECHR: ${ }^{28}$ it would have a judge in the ECtHR and its institutions would be responsible for violations of the Convention before the relevant bodies of the Council of Europe.

The objective and reasoning of an accession is evident in the several steps taken over the years in order for it to take place. In 2002, the president of the CJEU had supported accession, because it

\footnotetext{
${ }^{28}$ Report to the Committee of Ministers of the Council of Europe on the elaboration of legal instrument for the accession of the European Union to the European Convention on Human Rights, CDDH (2011)009 (Strasbourg, 14 October 2011), "Draft Explanatory report to the Agreement on the Accession of the European Union to the Convention for the Protection of Human Rights and Fundamental Freedoms" $\$ 7$. <http://www.statewatch.org/news/2011/oct/eu_cddh_Convention_report.pdf. $>$.
} 
would create uniformity in the protection of human rights in Europe. ${ }^{29}$ The Commission expressed its belief that accession would develop a common culture of fundamental rights in the EU, reinforce the credibility of the EU's human rights system and of EU external policy, demonstrate that the EU supports the ECHR and ensure a harmonious development of the jurisprudence of the CJEU and the ECtHR. ${ }^{30}$

The Parliamentary Assembly of the Council of Europe, in Resolution $1610^{31}$ and Recommendation $1834^{32}$ in 2008 also supported accession. In Resolution 1610 the Parliamentary Assembly underlined the contrast that, while accession to the ECHR is necessary for all candidate Members of the EU, the EU is not formally bound by the Convention. The lack of accession, according to the Assembly, precludes EU citizens from having recourse to the ECtHR where the Union violates Convention rights, since there is no external judicial control for such possible violations.

The Assembly also made an important point in paragraph 6.5 of this Resolution, where it stated that the execution of ECtHR judgments where EU matters are involved cannot be easily attained. This highlights the fundamental gap which is at the centre of the hypothesis - it is important for individuals to have effective recourse against the EU when they claim a violation of their rights, and that may only be done once the procedure they initiate allows them to obtain a substantive remedy for the violation. If a favourable judgment by the ECtHR is obtained but it is inexecutable because the measure emanates from a state's EU obligations, that vitiates the effort put by the individual applicant to go through all domestic legal remedies and prove their case in Strasbourg.

29 European Court of Human Rights Annual Report of 2001, Address given by Gil Carlos Rodriguez Iglesias, President of the Court of Justice of the European Communities, on the occasion of the Opening of the Judicial Year (Strasbourg, 31 January 2002) <http://www.cvce.eu/viewer/-/content/c201f6b4-21c4-408b-9a723b083048d5ec/en>.

30 Hearing of the European Parliament's Constitutional Affairs committee, Address by Viviane Reding, The EU's Accession to the European Convention on Human Rights: Towards a Stronger and more coherent protection of Human Rights in Europe (18 March 2010) < http://ec.europa.eu/commission_20102014/reding/pdf/speeches/speech_20100318_1_en.pdf>.

31 Council of Europe Parliamentary Assembly Resolution 1610 (2008) <http://assembly.coe.int/Main.asp?link=/Documents/AdoptedText/ta08/ERES1610.htm\#1>.

32 Council of Europe Parliamentary Assembly Recommendation 1834 (2008) <http://assembly.coe.int/Main.asp?link=/Documents/AdoptedText/ta08/EREC1834.htm>. 
A legal basis for accession within the Convention came with the $14^{\text {th }}$ Protocol to the Convention of 2010. Article 17 of the Protocol provides that Article 59(2) of the Convention will be amended to state that the "European Union may accede to the Convention". But since the EU is an international organisation with characteristics different to the other contracting parties, a special agreement would be needed. ${ }^{33}$ The EU Council asked the Commission to start accession negotiations in 2010. ${ }^{34}$ The Council of Europe asked the Steering Committee for Human Rights (CDDH) to elaborate an instrument for the accession. ${ }^{35}$ The final Draft Accession Agreement was presented to the Council of Europe's Committee of Ministers' deputies on the $14^{\text {th }}$ of October 2011.

After Accession, on the basis of Article 35 ECHR, an individual could bring a claim against the EU in the ECtHR for violating a Convention right. Under Article 46, a judgment finding the EU in violation of the Convention would be binding on it. If a claim were to be brought against the EU, all of the EU's judicial remedies must have first been exhausted before applying to Strasbourg. ${ }^{36}$

Apart from the possibility of directing a claim against both the EU and a Member State, the Draft Accession Agreement's co-respondent mechanism would both the EU and the Member States to be jointly responsible, if they voluntarily chose to participate when an EU rule is challenged. Both the EU and the Member State(s) would be jointly bound by a finding of violation. There are two ways for this mechanism to be triggered. The first is when the claim is brought against a Member State, and the EU chooses to join as a co-respondent. According to Article 3(2) of the Draft Agreement, this occurs when the Member State is fulfilling an EU obligation, and the claim would be avoided if the obligation was disregarded. The advantage is that since only EU institutions may amend their acts to remove the violation, ${ }^{37}$ their participation would hold them

33 cf. Draft Explanatory Report (n.28) §3.

34 X. Groussot, T. Lock and L. Pech, "EU Accession to the European Convention on Human Rights: a Legal Assessment of the Draft Accession Agreement of 14th October 2011" European Issues $\mathrm{n}^{\circ}$ 218, p.2 $\langle$ http://www.robert-schuman.eu/doc/questions europe/qe-218-en.pdf $>$.

35 Presidency, Council of the European Union, 'Accession of the EU to the Convention - State of play' (6 December 2011) §2 〈http://register.consilium.europa.eu/pdf/en/11/st18/st18117.en11.pdf〉 .

36 Article 35 ECHR.

37 Article 48 TEU. 
responsible to do so, since the judgment will be binding. ${ }^{38}$ In addition, the EU institutions will have an interest in defending their law. ${ }^{39}$

According to Article 3(3) of the Draft Agreement, when the original claim is against the EU, Member States may choose to become co-respondents when the question concerns the compatibility of the EU Treaties with the Convention. This in fact provides for the review of primary law. As only Member States may amend Treaties, ${ }^{40}$ they will have an interest in defending the law they have created, while the binding judgment will ensure amendment and compliance with the Convention. In essence - the sought aim was not to simply accede but rather implicate all parties in EU-related cases before the ECtHR so that the applicant could hope for a substantive remedy of the violation.

The history of the EU's accession came to an unceremonious halt with the delivery of Opinion 2/13 of the CJEU by virtue of Article 218(11) TFEU. The CJEU decided that the Draft Accession Agreement was not compatible with EU law, as it did not respect the autonomy of EU law. ${ }^{41}$ This decision of the CJEU can only come to confirm the core reasoning behind the Accession attempt: namely the creation of a uniform human rights regime in Europe, where the ECtHR would deliver judgments exercising scrutiny to EU action and that would be directly enforceable against EU institutions, thus allowing for the applicant to have access to substantive remedies. This decision also reveals an intimidation - if not hostility - that the CJEU feels at the idea of the EU's external accountability for human rights violations.

\footnotetext{
38 Article 216 TFEU and Article 46 ECHR.

39 cf. Groussot, Lock and Pech (n.34) 12.

40 Article 48 TEU.

41 For a detailed analysis of the reasoning of Opinion 2/2013 and its critique see B. de Witte and S. Imamovic, 'Opinion 2/13 on accession to the ECHR: defending the EU legal order against a foreign human rights court' (2015) ELR, 695 - 697, T. Lock, 'The future of the European Union's accession to the European Convention on Human Rights after Opinion 2/13: is it still possible and is it still desirable?' (2015) 11(2) ECLR 239, S. Lambrecht, 'The sting is in the tail: CJEU Opinion 2/13 objects to draft agreement on accession of the EU to the European Convention on Human Rights' (2015) EHRLR, 185, S.O. Johansen, 'The Reinterpretation of TFEU Article 344 in Opinion 2/13 and Its Potential Consequences [comments]' (2015) 16 German LJ 169, 169-178, 172, C. Rauchegger and S. Lambrecht, 'European Union: The EU's Attitude to the ECHR' in P. Popelier et al (eds.), Criticism of the European Court of Human Rights: Shifting the Convention System: Counter-Dynamics at the National and EU Level (Cambridge: Intersentia, 2016), L. Besselink, 'Acceding to the ECHR notwithstanding the Court of Justice Opinion 2/13' (December 23, 2014), http://www.verfassungsblog.de/en/acceding-echr-notwithstanding-courtjustice-opinion-213/\#.VNzHdPVm670, S. O' Leary, 'Courts, charters and conventions: making sense of fundamental rights in the EU' (2016) 56 Irish Jurist, 4-41.
} 
It is not within the remit of the present thesis to delve into potential solutions for non - accession or how accession may be achieved with the amendment of the relevant texts in order to fulfil Article 6(2) TEU. Nevertheless, non-accession marks a fundamental starting point. The nonaccession of the EU to the ECHR is a lost opportunity for individuals to have substantive redress against the EU. This compels the legal scholar to examine and research other methods for human rights victims to obtain substantive remedies. Before delving into that question, it is necessary to comprehend the repercussions on the remedies deficit, that are left behind by this lost opportunity.

\section{The effects of non-accession: no reform for remedies within the EU's legal system}

The ratification of the ECHR by the EU could have far reaching effects within the EU's legal system even on the remedies available before the EU courts. The basis for such a reform is the bindingness the Convention per se would have on the EU and its institutions.

Article 216 TFEU states that once signed, an international treaty binds the EU and all its institutions. Further to this, in Haegeman ${ }^{42}$ the CJEU held that the provisions of that treaty become part of EU law and have direct effect. The same rules will apply regarding the European Convention on Human Rights, should it be adopted. This initially appears to be a 'monist system' since it allows for international law to become binding immediately, and indeed commentators including Lenaerts support this approach. ${ }^{43}$

Secondly, the Convention could be directly invoked as an international obligation in judicial proceedings within the EU in a formal way. The CJEU has formulated specific circumstances where an international treaty is given effect. Per Intertanko ${ }^{44}$ the CJEU will examine whether the nature and broad logic of the treaty and whether the preamble and terms are such that it is possible to allow the treaty to be used as a standard of review of EU acts before the Courts under

42 Case 181/73 Haegeman [1974] ECR 449.

${ }^{43}$ K. Lenaerts, 'Droit International et Monisme de l'Ordre Juridique de l'Union' (2010) Revue de la Faculté de Droit de l'Université de Liège, 505.

${ }^{44}$ Case C-308/06, International Association of Independent Tanker Owners (Intertanko) and others $v$ Secretary of State for Transport [2008] ECR I-4057 $\$ 54$. 
Article 263 TFEU. The norm invoked must be unconditional and sufficiently precise to be used as a standard of review. ${ }^{45}$

Furthermore, EU measures may be subjected to a compatibility control with an international agreement, ${ }^{46}$ given that the agreement in question confers individual rights to persons influenced by the Union. This means that an international agreement is above secondary EU law because the latter can be tested for its validity with an international agreement because it is a 'rule of law relating to the application of the treaties.'

In order to be able to bring a claim on the compatibility of an EU measure with an international obligation, it is necessary for the agreement in question to confer rights to individuals and if this requirement is not satisfied, then the agreement is not invokable in EU or national courts. This is the reasoning of MOX Plant, ${ }^{47}$ Intertanko ${ }^{48}$, Biotechnology ${ }^{49}$ and Portugal $v$ Council. ${ }^{50}$

The Convention is evidently a rule of law which is intended to bind the institutions, should accession proceed. Since it is a human rights treaty, it is a clear example of individual rights conferral. The wording of the CJEU in Intertanko is that the international rule is invokable only where it confers individuals, rights and freedoms capable of being relied upon against states, a wording which described perfectly the ECHR and any other international human rights instrument. Therefore, it can be invoked in the Union's courts as a ground for review of secondary legislation, something which is already done as the Convention's rights form part of the general principles as indicated by the preceding analysis.

After the Accession, on the basis of Article 216 TFEU and the CJEU's case law on the incorporation of international obligations, the ECHR would become a document which would indeed bind the EU and therefore a set of rules relating to the application of the Treaties. Following accession, the ECHR would be officially hierarchically above the EU's secondary

\footnotetext{
${ }^{45}$ Case C-366/10 Air Transport Association of America and Others ECLI:EU:C:2011:864 \$74.

${ }^{46}$ Cases C- 21-24/72 International Fruit Company v Produktschap voor Groenten en Fruit [1972] ECR 1219 \$127.

${ }^{47}$ C-459/03 Commission v. Ireland [2006] ECR I-345 pp. 64-65.

${ }^{48}$ cf. Intertanko (n.44).

${ }^{49}$ Case C-377/98 Netherlands v Council [2001] ECR I -7079.

${ }^{50}$ Case C-149/96 Portugal v Council [1999] ECR I-8395.
} 
legislation because its incorporation in EU law may form a reason for the review of the legality of secondary legislation, which is an act of the institutions.

Another interesting aspect of this incorporation of the ECHR in EU law is the one of claims under Article 340 TFEU. This procedure allows for claims for damages when EU law provisions are violated by EU institutions. When international agreements become obligations binding the EU violations of them may be a cause of action under this Article. ${ }^{51}$ This would also be in accordance with the idea that the ECHR requires states to have legal mechanisms for the provision of monetary and non-monetary compensation in cases of violations of ECHR provisions. Article 340 could therefore function as the mechanism for monetary compensation after the Accession. Articles 263 and 340 TFEU both deal with EU administrative acts and secondary legislation but do not come to scrutinise the Treaties in any way but only apply them.

But the accession could allow for a review of the EU's primary law by the ECtHR, for which there is no procedure provided for within the EU's judiciary. EU primary law follows the traditional model of a treaty whereby the signatories of the treaty (the Member States) are the only ones able to amend it. This is provided for by Article 48 TEU. When accession was discussed, some were against the potential review of primary law, particularly the French Government, because that could place the Convention hierarchically above all EU law. ${ }^{52}$ Furthermore, as primary law can only be amended by the Member States, it would not be reasonable to hold the institutions responsible. ${ }^{53}$

However, the ECtHR usually reviews constitutional provisions for compatibility with human rights. ${ }^{54}$ In Matthews $^{55}$ the Court examined a case where the implementation of the primary EU law obligation caused an issue with ECHR rights. In this case the ECtHR held that the Member

51 cf. Craig and de Búrca (n.15) 367.

52 French Senate, "Communication de Robert Badinter sur le mandat de négociation” (E 5248) (25 May 2010), <www.senat.fr/europe/r25052010.html\#tocl> .

53M. Köngeter "Völkerrechtliche und innerstaatliche Probleme eines Beitritts der Europäischen Union zur EMRK" in J. Bast (ed), Die Europäische Verfassung - Verfassungen in Europa (Baden-Baden 2005) 230, 245.

54 cf. Groussot, Lock and Pech (n.34) 4, also see the judgment of the ECtHR in Sejdic and Finci v Bosnia and Herzegovina (App. No. 27996/06) ECtHR 22 December 2009 [2009] ECHR 2122.

55 Matthews v. United Kingdom (App. No. 24833/94) 18 February 1999 (1999) 28 EHRR 361, see also T. Lock, 'Walking on a Tightrope: the Draft Accession Agreement and the Autonomy of the EU Legal Order', (2011) 48 CMLRev 1025, 1038. 
State may be held responsible because the obligation is 'an international agreement freely entered into by the Member State'. Therefore, the ECtHR may find a Member State responsible for a violation and perform an indirect - albeit clear - critique of EU primary law.

The Draft Agreement expressly allowed for the review of primary law: Member States may be brought as co-respondents regarding obligations of EU institutions arising from primary law as they are its authors. ${ }^{56}$ After accession, a case arising from EU courts instead of national courts will involve acts of the institutions of the EU and will therefore bring into question the way that the Union courts have interpreted the Treaty obligations.

The Convention may be the grounds for review of the application and interpretation of Treaty articles by EU institutions with human rights. Therefore, human rights would acquire an optimum position with EU law hierarchy, forming the boundaries for any EU institutional action. In addition, the ECtHR would acquire the power to assess EU Treaty provisions as to their legality, something which is not even done by the Union's Courts. Article 267 TFEU provides that the CJEU has jurisdiction to rule on the interpretation of the Treaties or the validity and interpretation of acts of the institutions of the Union but unambiguously confers no power whatsoever for the Union's judiciary to annul, invalidate or assess the legality of any primary law provision. Indeed, it is very unlikely that the Member States intended to create an organ which could annul or invalidate the treaties concluded among them. ${ }^{57}$

The absence of accession means therefore that none of the above potential breakthroughs will take place. While the Accession could have far-reaching effects by improving the remedies and procedures for victims of human rights violations within the EU's judicial system, the possibility of these effects taking places has been eradicated.

\section{The effects of non-accession: continuing inaccessibility to ECtHR remedies}

1. Binding judgments of international tribunals and the CJEU

\footnotetext{
${ }^{56}$ Article 3(3) Draft Agreement.

${ }^{57}$ P. Gragl, The Accession of the European Union to the European Convention on Human Rights, (Hart 2013) 126.
} 
The greatest legal challenge presented by the EU's accession to the European Convention on Human Rights is the EU's submission to an external judicial control, namely the European Court of Human Rights. The presumption is that the judgments of the ECtHR, which have binding force, would allow potential claimants to have access to effective redress against the EU.

Starting with its earliest cases, the CJEU declared that EU law is an autonomous legal system, independent and different from other norms of international law. In Van Gend en $\operatorname{Loos}^{58}$ the CJEU - then known as the Court of Justice of the European Communities - stated that EU law forms a 'new legal order of international law, for the benefit of which, the states have limited their sovereign rights'. This means that the Member States have passed some of their lawmaking powers to the institutions of the EU.

On the basis of this rationale, in Costa $v E N E L^{59}$ the CJEU held that EU law is autonomous, since, as the Member States have passed some of their law-making powers to the EU institutions, it is for the EU institutions to develop, implement and interpret the according law. ${ }^{60}$ In this line, Article 19(1) TEU confers exclusive jurisdiction to the CJEU ensure the observation of the Treaties and interpret them, ensuring that the CJEU remains unconditionally the ultimate authority on the interpretation of EU law. ${ }^{61}$

According to Article 216(2) TFEU, any international treaty that the EU enters into, is binding upon the EU and its Member States. There is a body of jurisprudence in which the CJEU has hindered the conclusion of international treaties where such a treaty would jeopardise its exclusivity in interpreting EU law. For example, in Opinion 1/91 the issue concerned the proposed EEA Agreement where there was possibility of an EEA Court composed of EFTA and ECJ judges that would have the exclusive interpretation of the relevant Agreement. In this Opinion the ECJ ruled out the Agreement on the basis that it would introduce new rules into EU

58 Case 26/62 Van Gend en Loos v Nederlandse Administratie der Belastingen [1963] ECR -1.

59 Case 6/64 Costa v ENEL [1964] ECR 585.

${ }^{60}$ For further analysis see B. de Witte, 'European Union Law: How Autonomous is its Legal Order?' (2010) 65 Zeitschrift fur öffentliches Recht 141, 142, T. Schilling, 'The Autonomy of the Community Legal Order: An Analysis of Possible Foundations' (1996) 37 Harvard International Law Journal 389, 304.

${ }^{61}$ H.C. Kruger, 'Reflections Concerning Accession of the European Communities to the European Convention on Human rights' (2002) 21 Penn State International Law Review 89, 95, F.C. Mayer, 'Art 19 EUV' in E. Grabitz, M. Hilf and M. Nettesheim (eds) Das Recht der Europäischen Union Band I (Munich Beck 2010), 33, Y. Shany, The Competing Jurisdictions of International Courts and Tribunals (OUP 2003) 180. 
law, where the EU had already legislated similarly worded rules, and this would bring about a confusion of how the two sets of rules should be interpreted, with the possibility of divergent interpretations by the ECJ and the proposed Court.

In Opinion $1 / 91,{ }^{62}$ the ECJ held that when an international agreement that the EU enters into provides for its own judicial system, its decisions will be binding on the EU. The same is provided by Article 216 TFEU. However, in the same Opinion it was also stated that the interpretation of EU law by a court of another organisation in a binding manner would be a violation of the above autonomy, as the interpretation of EU law would be bound by another Treaty. This ensures interpretative autonomy: only the institutions of a particular legal order are entitled to interpret bindingly its rules. ${ }^{63}$

In Opinion $1 / 100^{64}$ the CJEU held that the creation of a European patents court with exclusive jurisdiction over European patent issues would deprive the ECJ of its ability to give preliminary rulings regarding EU patents law. In the same Opinion the ECJ held that when the EU acts concludes an international agreement, two elements are necessary for its autonomy to be preserved. First, the powers of the institutions must not be altered. Secondly, no institution outside the EU should interpret EU law in a binding manner. Only the CJEU has the ability to interpret EU law in a binding manner.

To avoid this, Article 344 TFEU comes in to provide that Member States may not submit any questions of interpretation of the Treaties to any other international dispute settlement procedure other than the General Court of the EU and the CJEU, which should have the last word on the issue. The ECHR has similar provisions, with Article 35 and 55 of the Convention requiring any dispute between the parties should not be brought first before other international investigation authorities or tribunals.

The Accession Agreement provided in Article 5 that procedures of the CJEU cannot be seen as international dispute settlement procedures as understood in the above two Articles, therefore allowing the CJEU to be the first to examine a dispute regarding the compatibility of EU law

\footnotetext{
${ }^{62}$ Opinion 1/91, [1991] ECR I-6079.

${ }^{63}$ cf. Groussot, Lock and Pech, (n.34) 5.

${ }^{64}$ Opinion 1/00 [2002] ECR I-3493.
} 
with the Convention. Although this seemingly respects the provision of Article 344 TFEU, it may also be read as a provision which establishes a clear hierarchy with the ECtHR being a supervising body which will judge on the issue after the CJEU and therefore be able to criticise its take on the legal problem, while the CJEU seems to take the status of a domestic court under review. This is of importance because the binding force of the ECtHR judgments will inevitably require a true and effective execution of the judgment within the EU, as it will be discussed immediately below.

2. Inability to access substantive remedies and achieve execution of ECtHR judgments

i. $\quad$ Substantive remedies within the framework of the ECHR

The ECHR differs from other agreements to which the EU is party, due to the method of adjudication and interpretation that the ECtHR uses. First of all, the ECtHR is a human rights court which is primarily concerned with how the parties to the Convention respect human rights within their legislative and administrative acts and not with disputes between the parties themselves. Secondly, unlike other human rights monitoring bodies, the ECtHR judgments have a full binding effect and need to be enforced. Finally, the ECtHR's method of interpretation of its treaty as a 'living instrument' often pushes for reforms of the domestic law.

The European Convention on Human Rights is the most effective system of protection of human rights at an international level. ${ }^{65}$ This effectiveness owes to the force and influence that the judgments of the European Court of Human Rights have on the law of the High Contracting Parties to the Convention. The systematic and rigorous implementation of the judgments delivered by the ECtHR is a part of the system without which the Convention would have little impact on the legal systems of the parties.

The foundation of this effectiveness is the Convention's provision that the Court's judgments are binding inter partes, ${ }^{66}$ therefore the respondent party in a case must comply with the Court's

\footnotetext{
${ }^{65}$ M. Marmo, 'The Execution of Judgments of the European Court of Human Rights - A political Battle' (2008) 15 MJECL 235, 236.

66 Article 46(1) ECHR. As judgments are binding inter partes, they bind, in principle, only the state party to the relevant proceedings, without generating any precedent. However, the jurisprudence of the Court combined with the
} 
decision and take steps to remedy the violation of the human right in question. In principle, the judgment binds only the state party to the case, and does not generate any precedent.

Nevertheless, the case law of the ECtHR is seen as an integral part of the Convention and by extent it has a binding force on all member states. ${ }^{67}$ The ECtHR held that according to the obligations of the Parties under Article 1 of the Convention, the jurisprudence of the Court should be taken into account by all Parties, which should streamline their domestic law with ECtHR case law. ${ }^{68}$ The Court itself has invited the Member States to comply with its judgments and adjust their legal systems, in order to remove the obstacles that prevent their citizens from accessing their rights. ${ }^{69}$

This renders the protection offered by the Convention of a higher quality compared to that offered by other international human rights instruments, such as the International Covenant on Civil and Political Rights or the International Covenant on Economic, Social and Cultural Rights, of which the supervising bodies merely have the power to make declarations simply of persuasive authority. It is also an international court of compulsory rather than optional jurisdiction, as opposed to the International Court of Justice. ${ }^{70}$

Furthermore, the Court's review is not limited to a judicial declaration on whether there has been a violation of the Convention right by the respondent state. While the judgment has a declaratory character, it is the secondary obligation, to make good the violation found, that gives substance to the breach of the Convention. ${ }^{71}$

remedies required after a judgment, influence the interpretation of the Convention's provisions by the ECtHR and domestic courts alike.

67 Resolution 1226/2000, Execution of judgments of the European Court of Human Rights, Parliamentary Assembly (30 ${ }^{\text {th }}$ Sitting), Council of Europe, para 3.

${ }^{68}$ Maestri v Italy (App. No 39748/98) ECtHR 17 February 2004 (2004) 39 EHRR 38 § 47.

${ }^{69}$ A. Mowbray, 'The creativity of the European Court of Human Rights', 5 HRLR 57 (2005), 72-78.

${ }^{70}$ G. Ress, 'The Effect of Decisions and Judgments of the European Court of Human Rights in the Domestic Legal Order' (2008) 40 Texas International Law Journal, 359-384, 363.

71 C. Tomuschat, 'What is 'Breach' of the European Convention on Human Rights?' in The Dynamics of the Protection of Human Rights in Europe: Essays in Honour of Henry G. Schermers, (Rick Lawson \& Matthijs de Blois ed, 2004) 315, 320-326. 
It is also notable, that the ECtHR has taken to giving instructions as to the measures to be taken by the State to rectify the breach, ${ }^{72}$ and therefore the Court can actually give instructions for individual measures. ${ }^{73}$ For example in Ilaşcu v. Moldova, ${ }^{74}$ the court held in its operative part of the judgment:

"The Court reiterates that, in the context of the execution of judgments in accordance with Article 46 of the Convention, a judgment in which it finds a breach imposes on the respondent State a legal obligation under that provision to put an end to the breach and to make reparation for its consequences in such a way as to restore as far as possible the situation existing before the breach.

22. Holds unanimously that the respondent States are to take all necessary measures to put an end to the arbitrary detention of the applicants still imprisoned and secure their immediate release"

This obligation which burdens the respondent State embodies the principle of restitutio in integrum. The Court with its judgment requires the situation to be restored in the status quo ante, meaning the situation which existed before the violation. The obligation to provide this remedy is inherent with every judgment of the ECtHR which finds a violation and derives from Article 46 of the Convention. The obligation to establish a situation ex-ante is a direct result of the delivery of a judgment which finds a violation. ${ }^{75}$

\footnotetext{
${ }^{72}$ M. Breuer, Zur Anordnung konkreter Abhilfemaßnahmen durch den EGMR: Der Gerichtshof betritt neue Wege im Fall Asanidse gegen Georgien, 31 (2004) Europäische Grundrechte Zeitschrift 257, Assanidze v. Georgia (merits and just satisfaction) (App No. 71503/01) ECtHR 8 April 2004 para. 203, Ilaşcu v. Moldova (Application No. 48787/99) ECtHR 8 July 2004 [GC] (2005) 40 EHRR 46, para. 490.

${ }^{73}$ M. de Salvia, 'La satisfaction équitable au titre des mesures individuelles et la pratique des organes de la Convention européenne des droits de l'homme : qu'en est - il du principe de sécurité juridique ?' in H. Hartig (ed) Trente ans de droit européen des droits de l'homme: études à la mémoire de Wolfgang Strasser (Brussels : Bryland, 2007) 46.

74 (2005) 40 EHRR 46.

${ }^{75}$ L. Loucaides, 'Reparation for violations of human rights under the European Convention and restitutio in integrum' (2008) EHRLR 2, 182-192, 189.
} 
Individual measures are relevant only to the applicant. ${ }^{76}$ The ECtHR 'provides' this remedy by making a suggestion as to the method of re-establishing the status quo ante. For example, in a series of cases against Turkey, regarding the right to a fair trial before an independent and impartial tribunal as provided for by Article 6 of the Convention, the Court decided that the most appropriate remedy would be the reopening of the judicial proceedings. ${ }^{77}$ In these particular cases, the Court took into account the specific facts and circumstances of the case, such as the lengthy imprisonment sentences that were imposed. ${ }^{78}$ The Court also held that in relation to complaints for unlawful taking of properties in the former communist regimes, the return of the property to the applicants would be the most appropriate form of restitutio in integrum. ${ }^{79}$

The Court may also include an injunction in the operative part of its judgments. The first case where this occurred was Assanidze ${ }^{80}$ where the ECtHR found violations of Article 5, paragraphs 1 and 3 regarding the lawful detention of the applicant and included an express order for the respondent state to proceed to the immediate release of the applicant. This option has proven to be useful for the remedying of the violation. ${ }^{81}$

Restitution is the most significant substantive remedy a victim of a human rights violation may receive. It allows for the violation to be eradicated; and this remedy is inherent in every judgment of the ECtHR. The absence of accession of the EU to the ECHR precludes potential applicants from obtaining this substantive remedy.

Beyond these individual measures, the objective of the Strasbourg Court is frequently not just the remedying of the specific violation in question but the passage of 'general measures' - legal reforms aimed at deterring further violations of human rights by the respondent party. Important

\footnotetext{
${ }^{76}$ O. Ichim, Just Satisfaction under the European Convention on Human Rights (CUP 2015) 206.

${ }_{77}$ Gencel v. Turkey (App. No. 53431/99) ECtHR 23 October 2003, Peker v. Turkey (App. No 53014/99) ECtHR 23 October 2003, Eren v. Turkey (App No. 46105/98) ECtHR 23 October 2003.

${ }^{78}$ L. Caflisch, La mise en ouvre des arrêts de la Cour: Nouvelles tendances' in F. Salerno (ed) La nouvelle procédure devant la Cour européenne des droits de l'homme après le Protocole no.14: actes du colloque tenu a Ferrara les 29 et 30 avril 2005 (Brussels: Bruylant 2007).

${ }^{79}$ Strain and Others v. Romania (App no. 57001/00) ECtHR 15 December 2005 ECHR 2005-VII, Olimpia - Maria Teodorescu v. Romania (App. No 43774/02) ECtHR 4 November 2008.

${ }^{80}$ Assanidze v. Georgia (merits and just satisfaction) (App No. 71503/01) ECtHR 8 April 2004.

81 cf. Ichim (n.76) and also joint concurring opinion of Judges Spielmann and Malinverni in Vladimir Romanov $v$. Russia App no. 41461/02, ECtHR 24 July 2008, concurring opinion of Judge Spielmann in Polufakin and Chernyshev v. Russia (App. No. 30997/02) ECtHR 25 September 2008, the joint concurring opinion of judges Rozakis, Spielmann, Ziemele and Lazarova-Trajkovska in Salduz v. Turkey (App. No. 36391/02) ECtHR 27 November [GC] (2008) 49 EHRR 421.
} 
changes have been brought about in several states, for example the decriminalisation of homosexual acts in private in Cyprus after the Modinos v Cyprus $^{82}$ judgment. This therefore requires legislative reforms and a different interpretation of the law in question by the competent judicial organs.

The first occasion on which the ECtHR required general measures explicitly is Broniowski. ${ }^{83}$ In this case the applicant's case related to property in the 'territories beyond the Bug River' in Poland. A part of the population had abandoned their properties in those areas following the Second World War, after which the borders had shifted. The reparation of that population was regulated by national law which the Court found as malfunctioning, noting that not only was the applicant's ability to claim compensation impaired but that that there could be numerous potential applicants in the same situation. The case therefore regarded a systematic violation and in the operative part of its judgment, the Court included an order requiring legal measures and administrative practices to ensure the implementation of the right to property.

In Scordino, ${ }^{84}$ the Court ordered the Italian government to take general measures to rectify the unjustified hindrance in obtaining reasonable compensation as well as the length of proceedings. In Dybeku, ${ }^{85}$ the Court ordered that the government take measures to secure appropriate conditions of detention and sufficient medical treatment for prisoners who require special medical attention.

The Court may also grant compensation known as just satisfaction, ${ }^{86}$ which means monetary compensation for the damage suffered by the victim of the violation as per Article 41 of the ECHR. That is considered to be a secondary form of reparation when restitution is not possible. ${ }^{87}$ Article 41 of the ECtHR provides that just satisfaction may be claimed by the applicant where the domestic legal system only allows for partial reparation of the violation.

82 Modinos v Cyprus (App. No. 15070/89) ECtHR 22 April 1993, Series A. 259 (1994) 16 EHRR 485.

${ }^{83}$ Broniowski v. Poland (App. No. 31443/96) ECtHR 22 June 2004 [GC] ECHR 2004-V.

${ }^{84}$ Scordino v. Italy (no.1) (App. No. 36813/97) [GC] ECHR 2006-V.

${ }^{85}$ Dybeku v. Albania (App. No. 41153/06) ECtHR 18 December 2007 [2007] ECHR 1109.

86 This is provided for by Article 41 of the Convention.

${ }^{87}$ M. de Salvia, 'Le principe de l'octroi subsidiaire des dommages-intérêts: d'une morale des droits de l'homme une orale simplement indemnitaire ?' in J-F Flauss and E. Lambert Abdelgawad (eds) La pratique d'indemnisation par la Cour européenne des droits de l'homme (Brussels: Bruylant 2011) 18. 
For just satisfaction to be granted, it is a prerequisite for a violation of the ECHR to have been found on the judgment on the merits. As a second prerequisite, the consequences of the violation must only be capable of being eradicated partially at the national level, therefore restitution on the basis of the obligation of the State to comply with the decision on the merits must not be possible. Thirdly, there must exist an injured party. Finally, there must be the estimation by the ECtHR that just satisfaction is necessary. ${ }^{88}$ The first two requirements are in essence admissibility requirements and the other two are the conditions for the compensation to be granted. ${ }^{89}$

Just satisfaction may be offered as a form of compensation for moral harm ${ }^{90}$ as well as material ${ }^{91}$ and pecuniary harm. ${ }^{92}$ For such an award, the Court requires a causal link, including where the victim claims a specific moral harm even if the moral suffering is inherent in every violation of a human right. ${ }^{93}$ The applicants must establish a direct causal link between the breach and the alleged damage. ${ }^{94}$ An example of such compensation is Loizidou ${ }^{95}$. The case regarded the inability of the applicant to return to her family home due to the ongoing military occupation of territory in the northern part of Cyprus by Turkey, which had to pay for the loss of property in north Cyprus.

Therefore, the EU could potentially be obliged to offer monetary compensation to an individual, should an act of its bodies violate the Convention's provisions. Given the unique system of protection offered by the ECHR, and the unique nature of the EU as an international organisation, the protection offered to the individual through the accession seems to be very farreaching, to the point of questioning where - if at all - it can be realistically implemented.

\footnotetext{
${ }^{88}$ De Wilde, Ooms and Versyp v. Belgium (just satisfaction) (App. no. 2832/66; 2835/66; 2899/66) ECtHR 10 March 1972, [1972] ECHR 1 Series A no. 14.

${ }^{89}$ E. Enrich Mas, 'Right to Compensation under Article 50' in J. Mcdonald, F. Matscher and H. Petzold (eds) The European System for the Protection of Human Rights (Dordrecht: Martinus Nijhoff, 1993), 779-84. See also P. Vegleris, 'Modes de redressement des violations de la Convention européenne des droits de l'homme: esquisse d'une classification' in Mélanges offerts a Polys Modinos: problèmes des droits de l'homme et de l'unification européenne (Paris: Pedone 1968).

${ }^{90}$ Halford v. the United Kingdom, 25 June 1997, Reports of Judgments and Decisions 1997-III para 76.

${ }^{91}$ Kadikis v. Latvia (no.2) (App. No. 62393/00) ECtHR 4 May 2006paragraph 67.

${ }_{92}$ Barbera, Messegué and Jabardo v. Spain (App. No. 10588/1983) (Article 50) ECtHR 13 June 1994, Series A no. 285-C Çakici v. Turkey (App No. 23657/94) ECtHR 8 July 1999 [GC] 31 EHRR 133. Salman v. Turkey [GC] (App. No. 21986/93) ECHR 2000-VII, Ertak v. Turkey (App no. 20764/92) ECtHR 9 May 2000, ECHR 2000-V.

${ }^{93}$ cf. Ichim (n.76) 22.

${ }^{94}$ Matthew v. the Netherlands (App. No. 24919/03) ECtHR 29 September 2005, Paras 223-4.

95 Loizidouv Turkey (Just Satisfaction) (App. No. 16318/89) ECtHR 28 July 1998, ECHR 1998-IV.
} 
The system of remedies in the ECtHR is complimented by the option of a friendly settlement. Article 39 of the ECHR allows the Court to place itself at the disposal of the parties with a view to securing friendly settlement. This avoids a win-lose situation at the end of a long procedure, ${ }^{96}$ while it also allows the victim to obtain a remedy without a judicial declaration of a violation, thus avoiding the creation of precedent for the respondent state. ${ }^{97}$

This procedure, drawing from the concept of the peaceful settlement of disputes in international law allows the parties to negotiate among them a financial award which will bring a settlement without proceeding to a judgment, as well as individual measures. ${ }^{98}$ For example in Broniowski, the respondent state assumed responsibility to effect legislative changes in the domestic legal system to ensure that there would be redress for individuals in comparable situations as the applicant. ${ }^{99}$ The Grand Chamber in this particular case scrutinised the extent and the length of the scope of the changes proposed to be effected. It is also possible for the Court, through its Registry, to suggest or propose the terms of the friendly settlement. ${ }^{100}$

\section{ii. Execution of judgments within the ECHR framework}

Following the issuance ECtHR's judgments, there are additional mechanisms of the Convention which provide for the supervision of the execution of the judgments and the substantial remedying of the violation by the respondent state, including restitution in integrum. Therefore, the Convention not only demands commitment, but also practical enforcement.

The supervision of the execution of judgments is a task undertaken by the Committee of Ministers. ${ }^{101}$ The Committee calls the respondent state to explain what has been done on its part

\footnotetext{
96 cf. Ichim (n.76) 181.

97 A. Kiss, 'Conciliation' in J. Mcdonald, F. Matscher and H. Petzold (eds) The European System for the Protection of Human Rights (Dordrecht: Martinus Nijhoff, 1993), 703.

98 Bulus v. Sweden (Application no. 93390/81) Comisssion's report of 8 December 1984, Ahmed v. Sweden (Application no. 9886/05) Commission's report 22 February 2007, Jager v. Switzerland (App. No 13467/87) Commission's report of 11 December 1989, Nagel v. Austria (App. No 7614/76) Commission's report of 2 May 1978, Zimmerman v. Austria App. No. 8490/79, Commission's report of 6 July 1982.

${ }^{99}$ Broniowski v. Poland (friendly settlement) (App no. 31443/96) ECtHR 28 September 2005 [GC] ECHR 2005-IX.

${ }^{100}$ V. Berger, 'Le règlement amiable devant la Cour' in L-E Pettiti, E. Decaux and P-H Imbert (eds) La Convention européenne des droits de l'homme. Commentaire article par article (Paris: Economica, 1999), I. Cabral Barreto, 'Le règlement amiable devant la Cour européenne des droits de l'homme' (2002) Bulletin des droits de l'homme 10.

101 Article 46(2) and Article 54 ECHR.
} 
to remedy the situation if a violation has been found, ${ }^{102}$ therefore fulfilling further the task of ensuring restitution of the victim. ${ }^{103}$

It has been stated that the Convention relies for its enforcement on a combination of binding legal obligation and the traditional good faith required of the signatories to an international agreement. ${ }^{104}$ The Committee of Ministers' conviction depends on political pressure, since in itself the Committee is composed of the Ministers of Foreign Affairs of the Contracting Parties. ${ }^{105}$ There is, therefore, no absolute guarantee that the respondent party will comply with the judgment, while the measures taken by the respondent party to comply are left to its own discretion. $^{106}$

The pressure exercised by the Strasbourg institutions is considerable. The Committee of Ministers has to be persuaded that the Party has taken all possible measures to abide by the judgment before adopting a resolution declaring that the party has fulfilled its obligations. ${ }^{107}$ If the respondent party has not taken the appropriate individual or general measures to rectify the breach, the case will be brought before the Committee every six months. Furthermore, the prospect of sanctions, should the respondent fail to comply, demands a high level of commitment on the part of the contracting parties, to obey the decisions of the Strasbourg institutions.

After the EU's accession, this would have to be reconciled with the notion of 'exclusive interpretation' by the CJEU. The CJEU claims to be the sole interpreter of EU law provisions, but this may change given that after a case against the EU in Strasbourg a re-interpretation of the law as well as administrative action may be demanded, having in mind the decision of the Strasbourg Court.

Another method of execution of judgments are sanctions, that are used by international organisations to push the States parties to them to comply with the rules of the relevant

\footnotetext{
102 Rule 3 of the Rules of Procedure (May 2006). See also Jacobs, White and Ovey, The European Convention on Human Rights (7th edn, OUP, 2017) 57-63.

${ }^{103}$ cf. Ichim (n.76) 33.

104 R. Ryssdal, Lecture Given at Masaryk University, March 1996.

105 cf. Marmo (n.65) 246.

106 Application Nos. 5947/72, 6205/73, 7052/75, 7061/75, 7107/75, 7113/75 and 7136/75, [1983] ECHR 5, para. $113(\mathrm{~d})$.

107 Rule 17 of the Rules of Procedure.
} 
organisation. In the Council of Europe such sanctions are limited. The Committee may sometimes address the State concerned directly, either through bilateral letters from its chairman to the relevant government or the use of interim resolutions by the Committee of Ministers which are made to the state authorities responsible for the violations. The only extensive sanction is the expulsion of a party from the Council of Europe under Articles 3 and 8 of the Statute of the Council of Europe. This may prove to be counterproductive, given that the relevant party will no longer be under the obligation to respect human rights.

iii. The EU, substantive remedies and execution of judgments of the ECHR

Returning to the question of the lack of remedies against the EU due to the non-accession to the ECHR, one has to take into account the above points. The EU law's 'independence' of other international obligations seems to be limited once it enters into an agreement with such developed system of remedies, adjudication and legal interpretation as the one of the ECHR. It becomes clear however, that given the developed system of remedies of the ECHR, the nonaccession contributes to a deficit by not allowing individuals to have an opportunity to claim this redress against violations of human rights by the EU.

The existence of possible remedies and the supervision of the Committee of Ministers demonstrate the extent to which EU law may be influenced by the possible external responsibility of the EU before the ECtHR. The remedy of restitution is therefore unavailable for the applicant wishing to obtain substantive redress against the EU given that this does not exist within the fabric of EU law. The possibility of general measures is the most permeating concept which may force the EU to alter its own legislation to fit the protection of human rights standards envisaged by the ECHR.

The system of enforcement and remedies under the ECHR has been characterised as one that gradually changes the sphere of state sovereignty. ${ }^{108}$ If the EU is subjected to these, there is no doubt that its own sovereignty will also be gradually changed. Yet, the persons who may be influenced by EU action would gain the ability to have access to these substantial and rigorous remedies where their rights are violated.

\footnotetext{
108 cf. Ress (n.70) 364.
} 


\section{E. Conclusion}

The absence of accession of the European Union to the European Convention on Human Rights has left the significant problem of lack of accountability and accessibility to remedies in relation to human rights violations by the EU unresolved. The dismissal of the Accession Agreement has rejected the most evident therapy to heal this open wound in European human rights law.

Initially, Article 6(2) TEU which provides for accession of the EU to the European Convention on Human Rights remains unfulfilled following the CJEU's reasoning, which makes the provision of the Treaty dormant, if not obsolete. This effectually means that persons who believe their rights have been infringed cannot have access to the remedies provided by the European Court of Human Rights. Those include both the recognition of a human right violation but perhaps more importantly the access to substantive remedies such as just satisfaction, restitution and general measures that lead to the reform of the legal regime that has allowed the violation. The person who wishes to obtain substantive redress against violations of her rights by the EU is left to hope to find the solution within the provisions of EU law, before the EU judicature. Even more theoretically a potential victim of a human rights violations of the EU may risk to engage the EU's international legal responsibility as an international organisation. This will form the discussion of the subsequent Chapters.

This lack of accession is significant given that while the EU pledges to respect the ECHR there is no formal way to hold the EU accountable for its violations given that it is not formally part of EU law. Consequently, persons whose rights may be violated by the EU are deprived of the possibility of accessing the remedies of the most rigorous system of human rights protection worldwide. 


\section{Chapter 2}

\section{The action for annulment - an inaccessible internal remedy}

\section{A. Introduction}

The present Chapter will address one of the most controversial problems of EU law and its repercussions for human rights violations. That is the action for annulment - or judicial review procedure which is provided for by Article 263 of the Treaty on the Functioning of the European Union.

The procedure envisaged by Article 263 is the most relevant legal procedure ratione materiae, where an individual claims their rights have been violated by the EU. It allows for the annulment of an EU by the CJEU, due to its illegality. As it will be demonstrated along this Chapter, a violation of a human rights norm is in itself an illegality - a ground for judicial review and annulment - that may lead to the eradication of the EU act, thus functioning as a legal remedy.

There is, however, one persistent problem which renders the remedy of annulment ineffective and of limited value to human rights protection. This drawback are the strict standing criteria set by the CJEU's case law, that have left individual applicants severely handicapped to apply for annulment for measures not directed specifically at them. This problem is deteriorated by limitations in the material scope of application of the procedure in all areas of EU law and action.

\section{B. A potentially effective remedy}

1. The relationship between annulment and human rights

The action for annulment, as provided for by Article 263 TFEU, is a procedure by which an EU legislative or executive act may be challenged and annulled by the EU's court. It sits at the core of judicial protection in the EU because it is a direct challenge of legality and the CJEU retains 
the exclusive jurisdiction to declare an EU act void. ${ }^{1}$ The present section will examine the function of the remedy of annulment in the protection of human rights. The hypothesis of this section is that the remedy of annulment is significant for human rights protections because it allows the violating act to be eradicated, but it is not effective in that individual applicants encounter debilitating obstacles in accessing the remedy.

According to Article 263(1), the CJEU may review the legality of legislative acts, of acts of the Council, of the Commission and of the European Central Bank, other than recommendations and Opinions, and of acts of the Parliament and of the European Council, intended to produce legal effects vis-à-vis third parties. The CJEU has held that the action for annulment must be available in the case of all measures adopted by the institutions regardless of nature or form, provided they are intended to have legal effect. ${ }^{2}$

In order for an act to be reviewable certain criteria must exist: the act must be the outcome of an internal procedure laid down by law, of a power provided for by law and must be intended to produce legal effects. ${ }^{3}$ According to Lenaerts et $a l^{4}$ the challenged measure must have a legitimate legal basis, reflect the definitive position of a Union institution, body, office or agency and be intended to have legal effects. Legal effects are produced where the act affects the interests of the applicant by bringing about a change in her legal position or restricting her rights. ${ }^{5}$ Therefore, the relationship between rights and the judicial review procedure becomes evident: the procedure is indeed designed to challenge acts that affect the legal position of individuals - which includes the restriction of legally conferred rights.

2. Two rights - related grounds of review

The essence of annulment as a remedy for human rights violations by the EU flows from two of the grounds of review referred to in Article 263(2) TFEU. The grounds on which one may claim annulment are the lack of competence, the infringement of an essential procedural requirement, an infringement of the treaties or any rule relating to their application, or the misuse of powers.

\footnotetext{
${ }^{1}$ K. Lenaerts, I. Maselis, K. Gutman, and J.T. Nowak, EU Procedural Law (OUP 2014) 254.

2 Case 22/70 Commission v. Council [1971] ECR 263, para 42.

${ }^{3}$ Case 182/80 Gauff v. Commission [1982] ECR 799, para. 18.

${ }^{4}$ cf. Lenaerts et al (n.1) 261

${ }^{5}$ Ibid, 268 and also Case T-554/93 Saint and Murray v. Council and Commission [1997] ECR II-563, para 41.
} 
Of these grounds, two of these are directly related to human rights violations, because they are concerned with the result that the act has had on individuals. These are the infringement of an essential procedural requirement or an infringement of the treaties or any rule relating to their application.

\section{i. Essential procedural requirements}

The provisions related to essential procedural requirements in EU law today are contained Chapter V of the Charter, with the title 'Citizens' Rights', which undoubtedly highlights the relationship between procedural requirements and rights. Article 41 of the EU Charter establishes the right to good administration which in the Union signifies the right of citizens to have one's affairs handled impartially, fairly and within a reasonable time by Union administrative or executive bodies.

Article 41(2) breaks this right down into three parts. Firstly, each person has the right to be heard before a measure affecting her is taken. Secondly, each person must have access to his or her file when such a measure is to be taken. Thirdly, the administration is under an obligation to give reasons for the decisions it takes. Beyond the primary law provisions, ${ }^{6}$ decisions in the EU Courts expressly accept these as essential procedural requirements that should be respected by EU institutions and refer to the three parts of Article 41(2) as such. ${ }^{7}$

The rights that are enumerated in Article 41(2) of the Charter are not necessarily exhaustive and they may include further sub-rights within them which may be developed by the jurisprudence of the CJEU, since the right to good administration was also initially conceived as a principle by the Court's jurisprudence. ${ }^{8}$ The Explanations on the Charter of Fundamental Rights essentially state that Article 41 is a codification of the general principle of good administration found in EU case law. ${ }^{9}$ The explanations on Article 41 state that the wording is inspired by certain cases,

\footnotetext{
${ }^{6}$ Articles 41 and 42 of the Charter, Articles 11 and 13 TEU Article 15 TFEU

${ }^{7}$ Case C-348/12 P. Council of the European Union v Manufacturing Support \& Procurement Kala Naft Co., Tehran [2013] ECR -00000 see paragraphs 66, 67, 68, Joined Cases C-584/10 P, C-593/10 P and C-595/10 P Commission and Others v Kadi [2013] ECR, 'Kadi II', § 97, Case C-49./88 Al-Jubail Fertilizer v. Council [1991] ECR I-3187, $\S 15$, Case T-192/08, Transnational company 'Kazchrome’ AO v. Council [2011] ECR II-7449, § 110.

${ }^{8}$ M. V. Kristjánsdóttir, 'Good Administration as a Fundamental Right' (2013) 9(1) Icelandic Review of Politics and Administration, 237-255, 240.

${ }^{9}$ Explanations Relating to the Charter of Fundamental Rights [2007] OJ C303/28.
} 
specifically Heylens ${ }^{10}$ where the Court stated that where the protection of a fundamental right is at stake the individual must be able to defend that right and have the possibility of deciding, with full knowledge of the relevant facts, whether there is any point in their applying to the courts.

According to the Explanations, this reasoning on the principle was further accepted in cases such as TU München, ${ }^{11}$ Lisretal $^{12}$ and Nölle. ${ }^{13}$ Procedural rights are also related to the right to effective judicial protection, which is of great importance for persons who wish to claim their rights have been infringed. Indeed, in Kadi (2013) ${ }^{14}$ the CJEU stated that the right to effective judicial protection embodied in Article 47 of the Charter encloses within it the duty of the relevant institution to provide reasons and the right of the affected person to make their view known - something also found within Article 41 of the Charter. Furthermore, the rights of the defence, according to EU case law, are of extreme importance in the particular cases when the Union institution takes action which involves a penalty or sanction. ${ }^{15}$ These rights include the right to be heard, access to one's file and the duty to give reasons for the decisions taken.

Article 41(2) of the Charter states that, "every person has the right to be heard, before any individual measure which would affect him or her, adversely is taken". This provision roughly adopts the approach of the CJEU and the Advocate General in Transocean. ${ }^{16}$

While the case law remains adamant on the expression of this general rule, in a more detailed explanation the CJEU has held that the right guaranteed in Article 41(2) of the Charter

\footnotetext{
${ }^{10}$ Case 222/86 Union nationale des entraîneurs et cadres techniques professionnels du football (Unectef) v Georges Heylens and others ECR 1987 -04097

11 Case C-269/90 TU München [1991] ECR I-5469

${ }^{12}$ Case T-450/93 Lisrestal [1994] ECR II-117

${ }^{13}$ Case T-167/94 Nölle [1995] ECR II-2589

${ }^{14}$ In Joined Cases C-584/10 P, C-593/10 P and C-595/10 P European Commission and Others $v$ Yassin Abdullah Kadi ECLI:EU:C:2013:518 the CJEU had stated that Article 47 of the Charter which is the right to effective judicial protection encloses the right to have reasons for the decision and to make one's view known, which are procedural requirements. See also Case C-300/11 ZZv Secretary of State for the Home Department ECLI:EU:C:2013:363, where it was stated that giving reasons for administrative decisions is allows effective judicial review.

15 Case T-655/11 FSL Holdings, Firma Léon Van Parys and Pacific Fruit Company Italy SpA v European Commission. Judgment of the General Court (Second Chamber) of 16 June 2015, § 47 where the GCEU stated that "it must be recalled that it is settled case-law that the rights of the defence in any proceedings in which penalties, especially fines or penalty payments, may be imposed, such as those provided for in Regulation No 1/2003, are fundamental rights forming an integral part of the general principles of law, whose observance the EU judicature ensures (see Almamet v Commission, paragraph 42 above, paragraph 21 and the case-law cited)."

16 Case C 17-74 Transocean Marine Paint Association v. Commission of the European Communities ECLI:EU:C:1974:106.
} 
guarantees every person the opportunity to make his views known effectively during an administrative procedure and before the adoption of any decision liable to affect his interests adversely. ${ }^{17}$ The observance of these rights, also contributes to transparency, openness and the respect on behalf of the Union, for the rights of natural or legal persons that may be influenced by its acts. Therefore, persons influenced by Union action know of their ability to challenge it, thereby further enhancing effective judicial protection, the access to a remedy and fair trial. ${ }^{18}$

The Court of Justice may find legislative acts and policy measures to be illegal because they limit one of the procedural requirements found in Article 41(2), as well as acts of the institutions during their legislative activity, such as refusing access to documents or consultation. Preparatory acts adopted by the institutions while legislating, are not legislative activity in themselves - that does not mean that because they may not be contrary to human or fundamental rights. What must be proven in these cases is that the challenged act is binding, ${ }^{19}$ it must be the outcome of the exercise of a power, upon the conclusion of an internal procedure laid down by law, intended to produce legal effect. ${ }^{20}$ The meaning of 'legal effect', in this context, has been defined early in the case law of the ECJ as the capability of affecting the interests of the applicant by bringing about a distinct change in her legal position ${ }^{21}$ or adversely affect her legal position by restricting her rights. ${ }^{22}$

The significance of this is that in terms of the respect of essential procedural requirements, the Courts expand their understanding of the concept of a reviewable act to preparatory measures. This enhances the protection of procedural rights and by extent the fundamental rights contained within procedural rights, not only after an act is finally adopted but also during its preparation. This is an effort to ensure that the end result of a decision-making process will respect the rights of persons affected by it and as such it is an ex ante or anticipatory remedy to human rights violations.

17 Case C - 277/11, M.M. v. Minister for Justice, Equality and Law Reform, Ireland and Attorney General [2012] ECR 00000

${ }^{18}$ In Joined Cases C-584/10 P, C-593/10 P and C-595/10 P European Commission and Others $v$ Yassin Abdullah Kadi ECLI:EU:C:2013:518

19 Joined Cases 1/57 and 14/57 Société des Usines à Tubes de la Sarre v. High Authority [1957] ECR 105.

${ }^{20}$ Case 182/80 Gauff v. Commission [1982] ECR 799, §18.

${ }^{21}$ Case 60/81 IBM v. Commission [1981] ECR 2639, §9.

22 Case T-541/93 Connaughton and Others v. Council [1997] ECR II- 549. 
Another significant feature of this ground of review is that it may be invoked by the Court itself, in its very early case law the Court of Justice raised on its own motion the question of whether an act is compliant with essential procedural requirements. ${ }^{23}$ Today, essential procedural requirements have been converted into fundamental rights in EU law that may be protected by the Courts irrespective of whether they are expressly relied upon as a ground for review in the application.

The current approach found in the case law is, that whether the Court may raise a point on its own motion depends on whether the review is related to the internal or external legality of an act. The external legality is concerned with the method employed for the adoption of the act. External legality regards the question of whether the relevant institution had the competence to take the measure or whether an essential procedural requirement has been infringed (the first and second grounds of review in Article 263(2)). The internal legality concerns the act's compatibility with legal norms, such as the general principles, the Treaties themselves and the misuse of powers. ${ }^{24}$ Therefore, the grounds related to internal legality are the infringement of the Treaties, a rule relating to their application or the misuse of powers (the third, fourth and fifth grounds of Article $263(2)) .^{25}$

The Courts have the obligation to raise a point on their own motion where the claim relates to the external legality of the contested act, ${ }^{26}$ while where the plea relates to the internal legality questions stated above, the Court may only examine it if it has been raised by the applicant, since the applicant must point out clearly which provisions are said to be violated. ${ }^{27}$ So while the inclusion of fundamental rights in procedural requirements may lead to raising a plea motu proprio, as Corthaut states, fundamental rights are not in general invoked as matters of public policy. ${ }^{28}$ Raising a matter of procedural requirements motu propio has a role in the protection of fundamental rights vis-à-vis Union acts. Given that essential procedural requirements contain fundamental rights and their respect also ensures respect for fundamental rights, this ability of

${ }^{23}$ Case 1/54 France v. High Authority [1954 to 1956] E.C.R. 1, point 15.

${ }^{24} \mathrm{cf}$. Lenaerts et al (n.1) 365.

${ }^{25}$ Case C-367/95 P Commission v. Systraval and Brink's France [1998] I-1719, § 67.

${ }^{26}$ cf. Lenaerts et al (n.1) 364-5.

${ }^{27}$ Case T-349/03 Corsica Ferries France v. Commission [2005] ECR II-2197.

${ }^{28}$ T. Corthaut, EU Ordre Public, (Kluwer Law International 2012) 186. 
the Union courts may contribute to the effective protection of fundamental rights within the EU legal order.

\section{ii. Infringement of the Treaties and any Rule Relating to their Application}

Article 263(2) provides that a separate ground of judicial review of an EU act is the violation of the Treaties or "any rule relating to their application". The EU's Treaties are the Treaty on the European Union, and the Treaty on the Functioning of the European Union. Rules that relate to their application include the Charter of Fundamental Rights of the EU and the general principles of EU law. All these sets of rules provide for human rights that are to be protected. This section will examine to what extent this ground of review functions as a vehicle for protecting human rights within the Union's legal system.

The Treaties themselves contain fundamental rights obligations for the Union. ${ }^{29}$ Part One, Title II of the TFEU is a good example of a set of such provisions. Within this Title, Article 10 obliges the Union to protect equality and combat discrimination. Article 13 refers to cultural rights and natural heritage. Article 16 embodies the right to privacy through the protection of personal data and gives the Union competence to lay down rules relating to the protection of such personal data. Article 17 provides that the Union must specifically respect religious organisations and churches as well as philosophical and non-confessional organisations, thus obliging the Union to respect the freedoms of religion, thought, conscience and association. There is, even to date, no case law to give guidance on these provisions as regards to claims against EU institutions, but Article 263(2) provides that any Treaty provision could be a ground for the review of legality.

The EU Charter on Fundamental Rights today has the same legal value as the treaties. ${ }^{30}$ This means that an Article 263 TFEU action may be based on a claim that an EU act is violating a Charter provision. According to Lenaerts, the importance of the Charter is that it should function

\footnotetext{
${ }^{29}$ General human rights obligations for the Union are found in Article 2 TEU stating that the Union is founded on the values for the respect of human dignity and human rights, Article 3 TEU whereby the Union shall uphold and promote the protection of human rights and the rights of the child, Article 6 TEU by which the EU recognises the rights contained in the Charter of Fundamental Rights, Articles 9 and 10 by virtue of which the Union must observe the equality of its citizens and ensure that citizens participate in the democratic life of the Union.

${ }^{30}$ Article 6(1) TEU, Article 51 EUCFR.
} 
as a frame for the activity of both the EU legislature as well as the judges of the EU Courts. ${ }^{31}$ Indeed, the EU Courts have occasionally annulled measures on the basis of their incompatibility with the Charter. ${ }^{32}$ The binding force of the Charter is significant in making the action for annulment procedure - in principle - a useful tool for obtaining a remedy in case of a human or fundamental right violation. Many of the rights included in the Charter have a broader scope than the ones that are guaranteed in the European Convention on Human Rights and others are so called third-generation rights which are not found in the Convention. For example, Article 37 of the Charter refers to sustainable development as part of the principles that ought to be included in the Union's policies. Article 34 of the Charter guarantees the right to social security, Article 17 talks of the right to asylum and Article 22 of the right to linguistic and cultural diversity. Therefore, there is a greater variety of rights which may serve as grounds for judicial review of EU action than what is available to the ECtHR when it reviews the compatibility of State conduct with human rights under the Convention.

The phrase "a rule relating to the application of the Treaties" found in Article 263(2) TFEU has been widely interpreted by Union courts. This refers to a set of jurisprudential creations called the 'general principles of EU law'. These jurisprudential fictions function as an aid for the interpretation of the object and purpose of the Treaties.

Fundamental rights became part of these general principles of EU law early on in the case law of the CJEU. ${ }^{33}$ In Nold $^{34}$ the ECJ held that international human rights instruments and common constitutional traditions of the Member States were the two sources of inspiration for the general principle. After the Lisbon reforms, Article 2 TEU states that one of the founding values of the EU is human rights. Article 6 TEU lists three sources of human rights law within the EU legal order: the Charter, the general principles and the European Convention on Human Rights.

\footnotetext{
${ }^{31}$ K. Lenaerts and J.A. Gutiérrez-Fons, 'The Place of the Charter in the EU Constitutional Edifice', in S. Peers, T. Hervey, J. Kenner and A. Ward (eds), The EU Charter of Fundamental Rights, (Hart Publishing, 2014) 1560.

${ }^{32}$ Cases C-402 and 415/2005 P Kadi and Al Barakaat International Foundation [2008] ECR I-6351, Cases 75 and 117/82 Razzouk and Beydoun v. Commission [1984] ECR 1509, Case 20/71 Sabbatini [1972] ECR 345. The Courts have struck down measures most notably in the area of sanctions, see Case T-228/02 Organisation des Modjahedines du Peuple d'Iran (OMPI) v. Council [2006] ECR II-4665, Case T-318/01 Othman v. Council and Commission EU:T:2009:187, Case T-253/04 KONGRA-GEL v. Council [2008] ECR II-46, Cases C-399 and 403/06 P Hassan and Aydi v. Council and Commission [2009] ECR I-11393.

${ }^{33}$ Case 11/70, Internationale Handelsgesellschaft v. Einfuhr - und Vorratsstelle für Getreide und Futtermittel [1970] ECR 1125.

${ }^{34}$ Case 4/73, Nold v. Commission [1974] ECR 491.
} 
Following the reforms of the Lisbon Treaty, human rights have moved beyond being part of the general principles underpinning the application of EU law. Given the above analysis, human rights have been codified in several EU law provisions, including the Charter and the two founding Treaties. The EU also draws significant inspiration from the European Convention on Human Rights and the European Court of Human Rights' case law. These may be seen as rules 'relating to the application of the treaties' given that they are not yet formally part of EU law.

Certain principles are found in both the treaties and the general principles. For example, the principle of proportionality, while being also included in the Treaties, is indeed a general principle underpinning EU law. Article 52 of the Charter explicitly states that where the Union passes a measure, any limitation of fundamental rights must respect principle of proportionality. Any limitation must be necessary and genuinely meet objectives of general interest recognised by the Union or the need to protect the rights and freedoms of others. Other principles are legal certainty, ${ }^{35}$ transparency and access to documents and the Courts. ${ }^{36}$

Additionally, the flexibility the Courts have to interpret EU law on the basis of these principles is important in the protection of fundamental rights because the Courts are given the opportunity to generate their own human rights case law. ${ }^{37}$ For example in Front Polisario, ${ }^{38}$ the application was filed by the organisation that represented the Sahrawi people of Western Sahara. The application concerned an Association Agreement with the Kingdom of Morocco regarding the liberalisation of trade between the Union and Morocco. The Agreement affected Western Sahara through Morocco's occupation of the territory, and the applicant's position was that it disrespected the Sahrawi's rights to development, self-determination, their rights to the natural resources as well as their rights to be heard, to have their affairs handled fairly. The CJEU set aside the first instance judgment of annulment by finding that the Association Agreement of the

\footnotetext{
${ }^{35}$ Case 98/78 Firma A Racke v. Hauptzollamt Mainz [1979] ECR 69, Joined Cases 53/63 and 54/63 Lemmerz-Werke $v$ High Authority [1963] ECR 23, Cases T-229 and 276/11 Lord Inglewood v. European Parliament EU:T:2013:127.

${ }^{36}$ Case C-266/05 P José Maria Sison v. Council [2007] ECR I-1233.

${ }^{37}$ To this end see W. Weiss, 'Is the CJEU Turning into a Human Rights Court?' in S. Morano Foadi and L. Vickers, Fundamental Rights in the EU - A matter of Two Courts (Hart, 2015) 75 and Joined cases C-92/09 and C93/09 Völker and Markus Schecke and Eifert [2010] ECR I-11063 where the CJEU conducted an intense review on the basis of proportionality and found that the EU legislator had not properly balanced the public interest for transparency against the applicants' rights to private life.

${ }^{38}$ Case C-104/16 P Council of the European Union v. Front populaire pour la libération de la saguia-el-hamra et du rio de oro (Front Polisario) ECLI:EU:C:2016:973.
} 
EU with Morocco, simply did not apply to Western Sahara. ${ }^{39}$ This finding was reached while the CJEU recognised that the people of Western Sahara were a self-governing people according to the principle of self-determination, thus allowing the CJEU, even if not providing an effective remedy, to put forward its thoughts on developing human rights concepts.

The general principles of EU law that have been developed by the jurisprudence of the Court have a very close relationship with human rights. They are the forerunners of fundamental rights as they are found today in the Charter and thus have played a crucial role in developing human rights as a reason for which EU acts may be annulled. It is because of this crucial relationship that the action for annulment has the potential to be an effective remedy.

\section{Standing - an insurmountable obstacle?}

Substantial remedies such as annulment lose their raison d'être when they become unattainable or inaccessible. This section examines how the standing criteria for judicial review in EU law hinder judicial review from providing an effective substantive remedy for human rights violations by EU institutions.

As per Article 263(2) TFEU, the European Parliament, the Council, the Member States or the Commission have the right to bring an action, without criteria being set. These bodies are therefore considered privileged applicants and always have standing. ${ }^{40}$ The obstacle to the effectiveness of this potential remedy for individuals is found in Article 263(4) TFEU, which deals with the rights of natural persons or non-institutional and non-governmental legal persons to bring an action against an EU act. Article 263(4) makes a distinction between addressees of the measure and parties who may be affected by the measure. Where the applicant is the addressee, they have standing. Where the applicant is a person affected by the measure but they are not the addressee, according to Article 263(4), the applicant must prove 'direct and individual concern' unless the measure is a regulatory act that does not require implementing measures in which case the applicant must only show 'direct concern'.

\footnotetext{
${ }^{39}$ Ibid, paragraphs 97-100.

${ }^{40}$ P. Craig and G. de Búrca, EU Law Texts Cases and Materials (6 $6^{\text {th }}$ edn OUP 2015) 514.
} 
This is a key issue in EU fundamental rights law, as it is directly related to the ability of natural and legal persons to claim their rights. The nature of the act challenged is important and necessary to be identified first, before the application of the standing criteria. Whether the challenged act is legislative or not, is decisive for which test for legal standing will be used by the Courts in judicial review procedures. According to Article 289 TFEU, the ordinary legislative procedure is the joint adoption of a Regulation, Directive or Decision by the European Parliament and the Council after a proposal by the Commission. These are considered to be the three types of legislative acts in EU law. In its third paragraph the provision mentions that 'legal acts adopted by legislative procedure shall constitute legislative acts'.

There are three other characterisations of 'acts' other than legislative that appear in Treaty provisions. ${ }^{41}$ First, Article 290 TFEU mentions that the Commission has the power to adopt 'delegated acts' if a legislative act so authorises. Such 'delegated acts' are non-legislative acts of general application aiming at the supplement or amendment of the main legislative act. ${ }^{42}$ Second, Article 291 introduces 'implementing acts': where there is the need for uniform conditions for the implementation of a legally binding act, this legally binding act may confer to the Commission the power to implement it. Third, Article 263(4) TFEU mentions the concept of 'regulatory act without need for further implementation', as a type of act that is subject to a different test for locus standi. However, the question is whether a regulatory act is synonymous to delegated and implementing acts will be dealt with in detail in Section III of this Chapter which also deals with standing.

The concept of a regulatory act is not yet well defined ${ }^{43}$ and it is unclear whether it is a new category of act, ${ }^{44}$ an umbrella term for implementing and delegated acts, or even a term which may include an act which may fall under any of the three existing categories but which requires

\footnotetext{
${ }^{41}$ For further analysis see Christiansen $\mathrm{T}$ and Dobbels $\mathrm{M}$ 'Non-legislative Rule Making after the Lisbon Treaty : Implementing the New System of Comitology and Delegated Acts' (2013) ELJ 42, Bergstrom and Ritleng D. (eds) Rulemaking by the Commission: The New System (OUP 2015).

${ }^{42}$ P. Craig, EU Administrative Law (2 $2^{\text {nd }}$ edn, OUP 2012), P. Craig, The Lisbon Treaty: Law, Politics and Treaty Reform (OUP 2010) 48-66 and B. Driessen, 'Delegated Legislation after the Treaty of Lisbon: An analysis of Article 290 TFEU' (2010) 35 ELR 837.

${ }^{43}$ M. Jaeger, 'L'accès des personnes physiques ou morales à la justice: les premières interprétations par le Tribunal des nouvelles dispositions de l'Article 263, quatrième alinéa, TFUE' in Weitzel L. (ed) L'Europe des droits fondamentaux : mélanges en hommage à Albert Weitzel (Zutphen Paris Legal Publishers, 2013).

${ }^{44}$ See also P. Stanley, 'The fine distinction between regulatory acts and acts that regulate' (2013) S.J. 157(40), 27.
} 
no further implementation. In cases such as Inuit ${ }^{45}$ and Microban ${ }^{46}$ the GCEU's approach on the matter was that a regulatory act is not a new type of act but rather a term which includes implementing and delegated acts.

Direct concern exists where the measure directly affects the legal situation of the applicant and leaves no discretion to the addressees of the measure who are entrusted with its implementation, ${ }^{47}$ without the interception of intermediate rules ${ }^{48}$ - therefore that would be a Decision or a Regulation, although it is not always clear whether there is some exercise of discretion between the original decision and its implementation. ${ }^{49}$ Individual concern in the sense of Article 263(4) TFEU has been a more complex notion. In 1963, the ECJ defined this criterion in Plaumann ${ }^{50}$ :

'Persons other than those to whom a decision is addressed may only claim to be individually concerned if that decision affects them by reason of certain attributes which are peculiar to them and distinguishes them from all other persons just as in the case of the person addressed.'

The test included the concepts of 'closed' and 'open' categories. In order to limit the standing and close the floodgates for indiscriminate claims, the ECJ held that when the measure was not directed at the applicant, the applicant should have been a member of a "closed category with fixed membership at the time of the decision", meaning a closed category with very specific attributes.

\footnotetext{
${ }^{45}$ Case C-583/11 P Inuit Tapiriit Kanatami and others $v$ European Parliament and Council of the European Union [2014] 1 CMLR 54.

${ }^{46}$ Case T-262/10 Microban International Ltd v European Commission [2011] E.C.R. II-7697.

${ }^{47} \mathrm{cf}$. Craig and de Búrca (n.40) 515.

${ }^{48}$ Case C-386-96, Société Louis Dreyfus \& Cie v. Commission [1998] ECR I-2309, Case C-486-01 P National Front v. European Parliament [2004] ECR I-6289, Case T-95/10 Cindu Chemicals BV v. European Chemicals Agency (ECHA) EU:T:2013:108, Case T-16/04 Arcelor SA v. European Parliament and Council [2010] ECR II-211.

${ }^{49}$ Case T-12/93 Comité Central d'Entreprise de la Société Anonyme Vittel v. Commission [1995] ECR II-1247, Case T-96/92 Comité Central d'Entreprise de la Société Générale des Grands Sources v. Commission [1995] ECR II1213, Case T-509/93 Richco Commodities Ltd v. Commission [1996] ECR II-1181,Cases T-172, 175 and 177/98 Salamander v. European Parliament and Council [2000] ECR II-2487.

${ }^{50}$ Case 25/62 Plaumann \& Co v. Commission [1963] ECR I-2343.
} 
In Calpak $^{51}$ the Court observed that an individual may challenge a regulation which is directed at another group of natural or legal persons, if in reality it was not a true regulation but a decision. This required considering the substance and the character of the challenged norm and whether it applied to "objectively determined situations and produced legal effects with regard to categories of persons described in a generalised and abstract manner'" In Codorniu ${ }^{52}$ the ECJ concluded that "the fact that the contested provision had a general application does not prevent from being of individual concern". Then one still had to satisfy the Plaumann criteria. Calls for relaxation of the locus standi criteria were made, most notably by Advocate General Jacobs in $U P A^{53}$ and by the GCEU (then CFI) in Jego Quere ${ }^{54}$ but the ECJ did not change its mind.

The Plaumann test has been therefore surviving since 1963, proving one of the most contentious issues in EU law as it is perceived by academics as highly formalistic to the point that it adversely affects fundamental rights and judicial protection, proving an insurmountable obstacle for individual applicants. ${ }^{55}$ Already in 1965, two years after the Plaumann decision, the applicants in Sgarlata $^{56}$ raised the point that the restrictive application of Article 263 (then Article 173 EEC Treaty) would in fact deprive individuals of effective judicial protection. The Court dismissed this argument stating that the wording of the provision is clearly restrictive. The Court not only refused the challenge to the criteria but stated expressly that a concern in relation to the effective judicial protection of individuals cannot override the wording of the Treaty provision.

In $F N A B,{ }^{57}$ the applicants challenged a Regulation on the basis of an infringement of a procedural requirement. The position of FNAB was that the Regulation was adopted by the Council without the proper consultation with Parliament, thereby infringing a procedural

\footnotetext{
${ }^{51}$ Joined Cases C-789/79 and C-790/69 Calpak SpA and Società Emiliana Lavorazione Frutta SpA v Commission of the European Communities [1980] ECR -01949

${ }^{52}$ Case C-309/89 Codorniu v. Council [1994] ECR I-1853.

${ }^{53}$ Case C-50/00P UPA v. Council [2002] ECR I-6677.

${ }^{54}$ Case T-177/01 Jégo Quéré v. Commission [2002] ECR II-2365

55 A. Albors-Llorens, 'Remedies against EU institutions after Lisbon - an era of opportunity?' Cambridge Law Journal 2012, 71(3), 532-33, cf. Craig and De Búrca (n.40) 519, A. Kornezov, 'Locus standi of private parties in actions for annulment: has the gap been closed?' (2014) 73(1) CLJ 25-28, 25, C.F. Bergstrom 'Defending restricted standing for individuals to bring direct actions against "legislative" measures' (2014) 10(3) ECLR 481-499, 481, cf. Lenaerts et al (n.1) 331, Case 487/06 P British Aggregates Association v. Commission [2008] ECR I-10515.

${ }^{56}$ Case 40/64, Sgarlata v Commission [1965] ECR 215, 227

${ }^{57}$ Case C-345/00, FNAB v Council [2001] ECR I-3811.
} 
requirement fundamental for democracy. The argument of the applicants was that the severe consequences for the fundamental rights of individuals constituted the application admissible. ${ }^{58}$ The Court dismissed this position stating that the seriousness of the alleged infringement by the institution concerned, or the extent of its adverse impact on the observance of fundamental rights could not, in any event, give rise to non-application of the rules for admissibility expressly laid down by the Treaty. ${ }^{59}$ What is more, the Court underlined that even where the Court has the right to raise an issue on its own motion the standing criteria must have been met, while they must also be met even when a serious infringement is being claimed.

This raises the rather disconcerting question of whether by this time the CJEU was not only rendering the judicial review procedure ineffective as a vehicle for human and fundamental rights protection, but also whether it was in fact contradicting the EU's adherence to human rights protection. As such, the criteria themselves may be seen as violating fundamental rights.

The Lisbon Treaty reforms did not make annulment proceedings a more prosperous forum for applicants who want to challenge EU measures, but Article 263(4) introduced the notion of regulatory acts that do not require implementation. The GCEU in Microban $^{60}$ and Inuit $^{61}$ dealt with this new notion of regulatory act.

In Microban ${ }^{62}$ the GCEU accepted as a regulatory act a decision by the Commission which was passed as part of its implementing rather than its legislative powers. In Inuit $^{63}$ an indigenous people who live in Canada, brought an action related to an EU Regulation which prohibited the trade of seal products. Among their claims was the breach of fundamental rights as an indigenous tribe and they also claimed that the Regulation was an act that required no further implementation. The GCEU defined 'regulatory act' as including general measures of nonlegislative nature, which in reality leaves only delegated and implementing acts under Articles 290 and 291 TFEU. $^{64}$

\footnotetext{
${ }^{58}$ Ibid, $\$ 37$.

${ }^{59} \mathrm{Ibid}, \S 40$.

${ }^{60} \mathrm{cf.}$ Microban (n.46).

${ }^{61}$ Case T-18/10 Inuit Tapiriit Kanatami v European Parliament [2011] E.C.R. II-5599.

${ }^{62}$ Ibid.

${ }^{63}$ Ibid.

${ }^{64}$ cf. Albors-Llorens (n.55).
} 
The decision of the GCEU in Inuit was upheld upon appeal by the Court of Justice in $2013 .{ }^{65}$ The arguments of the appellants included that the interpretation of the GCEU was contrary to the right to effective judicial protection under Article 47 of the Charter and that the GCEU had misinterpreted the meaning of Article 263(4). The Court of Justice dismissed these claims, and stated quite pointedly that Article 47 does not require that an individual should have an unconditional entitlement to bring an action for annulment and that neither that fundamental right nor Article 19(1) TEU require that an individual should be entitled to bring such actions before national courts and tribunals.

In the appeal, the Court also upheld the interpretation of 'regulatory act' as given by the General Court and did not attempt any further interpretation. The CJEU also referred to the travaux preparatoires of the Lisbon Treaty, claiming that it was never the intention of the treaty-makers to alter the standing criteria in terms of legislative acts.

Considering this decision, the remedy of annulment seems very distant for individuals who claim their rights have been infringed. The Court in this case interpreted the appellants' argument in a fashion which is substantially different from the argument's intentions, by stating that the appellants had claimed unconditional entitlement to bring an action for annulment of legislative acts - in order to reach a conclusion by which the appellants' arguments is rejected. This example of judicial activism by the CJEU can only be characterised as unfortunate.

Another post - Lisbon case that ought to be considered in this context is Front Polisario. ${ }^{66}$ The case concerned the Front Polisario, an organisation representing the Sahrawi people of Western Sahara, a disputed territory in Africa, where Morocco maintains illegal occupation. The act in question was an Agreement in the form of an Exchange of Letters between the European Union and Morocco (the Liberalisation Agreement) for the purposes of the reciprocal liberalisation of agricultural products, processed agricultural products, fish and fishery products between the EU and Morocco, by amending an already existing Association Agreement with Morocco. The applicants claimed that this conclusion of the Liberalisation Agreement was illegal because the

\footnotetext{
65 cf. Inuit (2013) (n.45).

${ }^{66}$ Case T-512/12 Front populaire pour la libération de la saguia-el-hamra et du rio de oro (Front Polisario) $v$ Council of the European Union ECLI:EU:T:2015:953
} 
Council did not take into account the status of Western Sahara as an occupied territory, and also violated the Sahrawi people's freedom and their rights to self-determination and development.

At first instance, the General Court considered the Liberalisation Agreement to be a legislative act and its position was that Front Polisario had standing because the Liberalisation Agreement covered products coming from Western Sahara, and also because the Front Polisario is the organisation that participates in the negotiations for the determination of the status of Western Sahara. ${ }^{67}$ It also found that the Liberalisation Agreement applied to Western Sahara since Morocco was applying the terms of the initial Association Agreement to Western Sahara.

Nevertheless, the faint ray of hope let by the first instance judgment of the GCEU disappeared with the judgment of the CJEU upon appeal. ${ }^{68}$ The CJEU accepted the Council and the Commission's appeal and dismissed the judicial review claim. In fact, it found that the Liberalisation Agreement did not apply to Western Sahara and therefore it excluded the possibility of standing without further assessment. The CJEU found that the GCEU had wrongly interpreted Article 31(3)(c) on the Vienna Convention on the Law of Treaties whereby a treaty must be interpreted in light of the relevant rules of international law that govern the relations between the parties. The CJEU identified three such rules.

First of all, the CJEU found that such an applicable rule was the principle of self-determination. The Court found that Western Sahara is a distinct territory from Morocco, which is awarded selfdetermination by virtue of the UN General Assembly Resolutions on it and the ICJ's Advisory Opinion on Western Sahara while it is also listed since 1963 in the self-governing territories by virtue of Article 73 of the UN Charter. ${ }^{69}$ Secondly, the CJEU referred to the rule in Article 29 of the Vienna Convention on the Law of Treaties which provides that a treaty only applies within the territory of the parties that agree to it unless there is another intention. The CJEU found that the GCEU wrongly concluded that the Association Agreement was tacitly accepted to apply to Western Sahara and that in the absence of an explicit provision for such application, Western Sahara was excluded from the application of the Association Agreement, falling outside the

\footnotetext{
${ }^{67}$ Ibid, paragraphs 109-114.

${ }^{68}$ Case C-104/16 P Council of the European Union v Front populaire pour la libération de la saguia-el-hamra et du rio de oro (Front Polisario) ECLI:EU:C:2016:973.

${ }^{69}$ Ibid, paragraphs 88-92.
} 
territory of Morocco. ${ }^{70}$ Third, the CJEU found that another principle applicable in this case was that of the relevant effect of treaties, as per Article 34 of the Vienna Convention on the Law of Treaties: treaties are not binding upon third parties except where there is the third party's consent. The CJEU found that the people of Western Sahara had not expressed such consent. ${ }^{71}$

Therefore, the CJEU again avoided a substantive analysis on standing criteria, in a case which raised important human rights issues. The CJEU's ruling confirms the restricted access that individuals may have to the Union's judiciary for human rights - related actions for judicial review. There is also an oxymoron in this particular judgment. That lies in the fact that the CJEU is adamant about the Western Sahara people's right to self-determination, which is an important statement, but at the same time, it uses this as a vehicle for the rejection of the judicial review action thereby avoiding substantive assessment of how the rights of the Western Saharan people may have been compromised given that the previous Liberalisation Agreement applied there.

On the basis of the above analysis, the standing criteria constitute the judicial review procedure an ineffective remedy for human rights claims against EU institutions. This gives rise to a broader judicial policy question, which is identified in the arguments of the parties' in the Inuit decision of the Court. This is whether the strictness of the criteria as formulated by the EU courts defeats in reality the point of the judicial review procedure. There is an important obstacle in such cases. The act may be legislative in nature but no national implementing measures have been taken. This means that it will not be possible to challenge the act at a domestic level, given that the state has had no discretion, while the potential applicant will face all these significant difficulties at the EU level. ${ }^{72}$ This inevitably reveals a lack of effective judicial protection. This means that the interpretation of the Court hinders the proper application of Article 47 of the Charter: effective judicial protection. ${ }^{73}$

\footnotetext{
${ }^{70}$ Ibid, paragraphs $97-100$.

${ }^{71}$ Ibid, paragraph 106.

${ }^{72}$ S. Peers and M. Costa 'Judicial Review of EU acts after the Treaty of Lisbon' (2012) 8(1) ECLR 82-104, 100.

${ }^{73}$ A. Kornezov, 'Shaping the new architecture of the EU system of judicial remedies: comment on Inuit' (2014) ELR 39(2), 251-263, P. van Malleghem and N. Baeten 'Before the law stands a gatekeeper - or what is a regulatory act in art.263(4) TFEU? Inuit Tapiriit Kanatami v European Parliament (C-583/11 P)' (2014) 51(4) CMLRev 1187-1216, J. Jones, 'Standing space only in the CJEU: comment on Inuit Tapiriit Kanatami v European Parliament and Council' (2014) 19(1) JR 65-72.
} 
This may only take us back to the reasoning of AG Jacobs in UPA. ${ }^{74}$ AG Jacobs was particularly critical of the Court's view that since individuals may trigger the preliminary ruling procedure, they have full and effective judicial protection against general measures:

"I consider, for all of those reasons, that the case-law on the locus standi of individual applicants as re-considered in the judgment in Greenpeace, whichever way that judgment is understood, is incompatible with the principle of effective judicial protection. While review of Community measures through proceedings before national courts may be appropriate where a case raises mixed issues of interpretation and validity of Community law, proceedings before the Court of First Instance under the fourth paragraph of Article 230 EC are clearly more appropriate where a case concerns exclusively the validity of a Community measure. Since such cases will by definition raise questions of law, the possibility of an appeal on points of law provided by Article 225 EC would ensure that the Court of Justice could exercise effective ultimate control over the decisions adopted by the Court of First Instance"

Advocate General Jacobs proposed that a solution for giving effective judicial protection is to recognise that an applicant is individually concerned by the measure where the measure has or is liable to have a substantial, adverse effect on their interests. This, according to Jacobs would give true direct access to a court and removed the 'anomaly' which is found in the case law. The same concerns and points continue to be raised since this Opinion until today, as the general view is that the criteria are overly strict and that there is need for relaxation of the criteria. ${ }^{75}$

${ }^{74}$ cf. $U P A(n .53)$.

75 C.F. Bergstrom 'Defending restricted standing for individuals to bring direct actions against "legislative" measures' (2014) 10(3) ECLR 481-499, 481, A. Kornezov, 'Shaping the new architecture of the EU system of judicial remedies: comment on Inuit' (2014) 39(2) ELR 251-263, A. Albors-Llorens, 'Sealing the Fate of Private Parties in Annulment Proceedings?: the General Court and the New Standing Test in Article 263(4) TFEU' (2012) 71 CLJ 52; S. Peers and M. Costa, 'Judicial Review of EU Acts after the Treaty of Lisbon: Order of 6 September 2011, Case T-18/10 Inuit Tapiriit Kanatami and Others v. Commission and judgment of 25 October 2011, Case T262/10 Microban v. Commission' (2012) 8(1) ECLR 82, P. Craig and G. de Búrca EU Law Texts Cases and Materials (2015) OUP 535, A. Creus, 'Commentaire des decisions du Tribunal dans les affaires T-18/10-Inuit et T262/10-Microban' (2011) 3 Cahiers de droit européen 659, A. Kornezov, 'Locus standi of private parties in actions for annulment: has the gap been closed?' (2014) 73(1) CLJ 23-28, A. Arnull, 'April Shower for Jégo-Quéré' (2004) 29 ELR 287, C. Koch, 'Locus Standi of Private Applicants under the EU Constitution: Preserving Gaps in the Protection of Individuals' Right to an Effective Remedy' (2005) 30 ELR 511, K. Lenaerts, 'The Rule of Law and the Coherence of the Judicial System of the European Union" (2007) 4 CMLRev 1625, T. Corthaut, 'Case CFI May 3, 2002, Jégo-Quéré v. Commission T-177/01 and C-50/00 P ECJ July 25, 2002, Unión de Pequeños Agricultores v 


\section{Limited scope for access to the remedy of annulment}

In order for a remedy to be attainable and by extent effective, it is necessary for it to be truly available. The action for annulment can only provide the channel for the substantive remedy for annulling the violating act if the procedure is available for acts that cover the areas of competence and action where human rights violations are most likely to occur. That is unfortunately not the case. The following analysis will explain why the scope of the judicial review action is unsatisfactory to the point that it cripples the ability of individuals to obtain substantive redress.

\section{Competence Areas where Judicial Review may occur}

The EU's competence areas are found in Articles 3 to 6 TFEU and include the customs union, monetary policy, competition, environment, social policy, internal market rules, consumer protection and energy. ${ }^{76}$ The policies passed in such a vast array of competence areas may affect human rights, as it happens with any legislative or administrative act. Indeed, the CJEU has heard judicial review cases for acts within the framework of the internal market, ${ }^{77}$ custom cases ${ }^{78}$ environmental policies, ${ }^{79}$ competition ${ }^{80}$ to mention only a few areas where judicial

Council' (2002) Columbia Journal of European Law 141; V. Kronenberg and P. Dejmek, 'Locus Standi of Individuals before Community Courts under Article 230(4) EC: Illusions and Disillusions after the Jégo-Quéré (T177/01) and Unión de Pequeños Agricultores v Council (C-50/00 P) judgments' (2002) 4 European Legal Forum 257; J. Schwarze, "The Legal Protection of the Individual against Regulations in European Union Law" (2004).

${ }^{76}$ Article 3 of the TFEU provides that the Union has exclusive competence in the areas of customs union, the establishing of the competition rules necessary for the functioning of the internal market; monetary policy for the Member States whose currency is the euro; the conservation of marine biological resources under the common fisheries policy and common commercial policy. The same article provides that the Union shall have exlcusive competence to conclude and international agreement where that is provided by a Union legislative act or where it is necessary for the exercise of the Union's internal competence. Article 4 TFEU provides that the Union has shared competence with Member States internal market; social policy, for the aspects defined in this Treaty; economic, social and territorial cohesion; agriculture and fisheries, excluding the conservation of marine biological resources; environment; consumer protection; transport; trans-European networks; energy; area of freedom, security and justice; common safety concerns in public health matters, for the aspects defined in this Treaty, while it also gives the Union competence in the areas of technology, research, space, development and humanitarian aid without compromising the competences of Member States exercising their respective competences in those areas. Article 5 TFEU gives the Union the competence to coordinate Member States in their economic, employment and social policies. Article 6 TFEU gives the Union competence, in the sense that measures passed are to support the Member States' policies, in the areas of protection and improvement of human health; industry; culture; tourism; education, vocational training, youth and sport; civil protection; administrative cooperation.

${ }^{77}$ cf. UPA (n.53).

${ }^{78}$ Cases T-187/97, T-190/97 to 192/97, T-210/97, T-211/97, T-216/97 to 218/97, T-279/97. T-280/97, T-191/97 and T-147/99 Kaufring and Others v. Commission [2001] ECR II-1337. 
review applications were filed. However, the CJEU cannot review all acts in every competence area and there are certain exemptions.

Before the Lisbon Treaty, the EU was based on three pillars by virtue of the 1992 version of the Treaty on the European Union: the European Community, the Police and Judicial Cooperation in Criminal Matters pillar and the Common Foreign and Security Policy. The two last competence areas were fully outside the jurisdiction of the CJEU. In the Lisbon Treaty, the Area of Freedom, Security and Justice (formerly Police and Judicial Cooperation in Criminal Matters), has been brought under the jurisdiction of the CJEU. ${ }^{81}$ This competence area contained in Title V of the TFEU, covers the external borders of the Union and asylum, ${ }^{82}$ judicial cooperation in civil ${ }^{83}$ and criminal $^{84}$ matters and police cooperation. ${ }^{85}$ Within this scope of competence, the Union has founded the agency for the monitoring of its external borders (FRONTEX), ${ }^{86}$ passed the Framework Decision on the European Arrest Warrant ${ }^{87}$ and established EUROPOL. ${ }^{88}$ The CJEU may hear judicial review actions on measures taken by the Union within these areas.

Indeed, law enforcement is a matter which gives rise to human rights problems - police operations may trigger violations of the right to life, the right to liberty and security or the prohibition on inhuman and degrading treatment. In these specific areas of judicial cooperation in criminal matters and police cooperation, the CJEU has no jurisdiction according to Article 276 TFEU to judge on the validity or proportionality of law enforcement authorities' acts. ${ }^{89}$ As the implementation of policies in these areas is primarily in the hands of national authorities, such as police, it is for the corresponding national authorities and courts to review them.

79 Case T-16/04 Arcelor SA v. European Parliament and Council [2010] ECR II-211 [97]. Case T-646/13 Bürgerausschuss für die Bürgerinitiative Minority SafePack - one million signatures for diversity in Europe $v$ European Commission ECLI:EU:T:2017:59.

${ }^{80}$ Case C-109/10 P Solvay v. Commission [2011] ECR 1-10329, Case C-413/06 P Bertelsmann and Sony Corporation of America v. Impala [2008].

${ }^{81}$ Articles 67-89 TFEU.

82 Title V, Chapter 2 of the TFEU.

83 Title V, Chapter 3 of the TFEU

${ }^{84}$ Title V, Chapter 4 of the TFEU.

85 Title V, Chapter 5 of the TFEU.

${ }^{86}$ Council Regulation (EC) 2007/2004 repealed by Council Regulation (EC) 2016/1624.

87 2002/584/JHA Council Framework Decision of 13 June 2002 on the European arrest warrant and the surrender procedures between Member States.

${ }^{88}$ Regulation (EU) 2016/794.

${ }^{89}$ Article 276 TFEU. 
For example, the Framework Decision on the European Arrest Warrant provides that the rights of a requested person, the arrest and detention procedures are determined on the basis of domestic law. ${ }^{90}$ Therefore, the proportionality of force in an arrest, police investigations and criminal proceedings are matters of domestic law that are to be reviewed vis-à-vis domestic human rights law and constitutional provisions, by domestic courts.

Another example of a non-reviewable act according to the case law is the EU's action taken within the European Stability Mechanism, which cannot produce an act that is considered to stem from EU action. In Konstantinos Mallis ${ }^{91}$ the case involved the adoption of a Memorandum of Understanding between the European Stability Mechanism, in which the Commission and ECB participated and Cyprus, for a direct levy from private bank accounts to secure economic stability. In Mallis the applicants claimed that the Commission's and the ECB's actions were in infringement of their right to property and thus sought annulment. The CJEU held that the role of the Commission and the ECB is limited as per the ESM Treaty and an action for annulment is not available against them since they do not adopt EU law acts in the context of their participation in ESM.

This decision may be contrasted with Ledra Advertising ${ }^{92}$ where the same actions were held to be subject to scrutiny regarding the Union's non-contractual liability (Part II). Therefore, this case demonstrates that as the EU's activities are expanding, the CJEU plays an important role in defining which of the EU's acts may in fact be reviewed.

It appears, therefore that there are indeed certain important exemptions from the jurisdiction of the Courts in relation to judicial review procedure. This undoubtedly cripples the effectiveness of this procedure as a means of protecting human rights. Another important exemption from the scrutiny of the CJEU is the EU's Common Foreign and Security Policy, examined immediately below.

2. The Jurisdiction of the CJEU in CFSP Matters and human rights

\footnotetext{
${ }^{90}$ Articles 11, 1213 of the Framework Decision.

91 C-109/15 P. Konstantinos Mallis and Others v European Commission and European Central Bank (ECB) Judgment of the Court (Grand Chamber) of 20 September 2016 ECLI identifier: ECLI:EU:C:2016:702

92 Joined Cases C-8/15 P to C-10/15 P Ledra Advertising Ltd and Others $v$ European Commission and European Central Bank (ECB) Judgment of the Court (Grand Chamber) of 20 September 2016 ECLI:EU:C:2016:701.
} 
The CJEU has a restricted jurisdiction over acts in the area of Common Foreign and Security Policy. Since the ratification of the Lisbon Treaty in 2009, the CJEU has the possibility to review an EU act in the CFSP field in two situations: first in order to review it in relation to matters of competence, ${ }^{93}$ and second, where the act imposes restrictive measures on natural or legal persons. ${ }^{94}$ This second exception is particularly important in relation to human rights protection.

The Court does not scrutinise either the decision-making procedure or the legal basis of the CFSP measure. ${ }^{95}$ The CJEU also lacks general jurisdiction to rule on whether the CFSP acts respect human rights. ${ }^{96}$ In addition, international agreements concluded by the Union within the context of the CFSP may be challenged through Article 263 TFEU for their compatibility with the Treaties and the Charter. ${ }^{97}$

As will be examined in Part III of the Thesis on the international human rights obligations of the European Union, acts by the EU in the CFSP area may interact with human rights, particularly where the Union undertakes military action or is involved in peacekeeping and capacity building. Articles 42 and 43 TEU give competence to the Union under the CFSP to conduct military and peacekeeping operations. According to Article 28 TEU these operations must be authorised by Council Decisions. Other aspects of the CFSP include the formulation of a common commercial policy, ${ }^{98}$ economic, financial and technical cooperation with third countries, ${ }^{99}$ the conclusion of international treaties by the Union, ${ }^{100}$ as well as the imposition of restrictive measures on states and natural or legal persons. ${ }^{101}$

\footnotetext{
${ }^{93}$ Article 40 TEU.

${ }^{94}$ Article 275 TFEU.

${ }_{95}^{95}$ B. van Vooren and R.A. Wessel, EU External Relations Law - Texts, Cases and Materials (CUP 2014) 379.

${ }^{96}$ M. Brkan, 'The Role of the European Court of Justice in the Field of Foreign and Security Policy after the Treaty of Lisbon: New Challenges for the Future', in P.J. Cardwell (ed), EU External Relations Law and Policy in the PostLisbon Era (The Hague: T.M.C. Asser Press, 2012) 100.

97 Case C-122/95 Germany v. Council [1989] ECR I-973, Case C-612/13 P ClientEarth v. Commission ECLI:EU:C:2015:486.

${ }^{98}$ Article 207, TFEU.

${ }^{99}$ Article 212 TFEU

${ }^{100}$ Article 216 TFEU.

${ }^{101}$ Article 215 TFEU.
} 
Action under the CFSP heading has long stayed outside the CJEU's jurisdiction, ${ }^{102}$ until the passage of the Lisbon Treaty in 2009. The Kadi ${ }^{103}$ litigation played a key role in this particular development. In $\mathrm{Kadi}^{104}$ the EU's judiciary faced a judicial review action for sanctions imposed on a person within the framework of the CFSP. The legal question in these cases concerned the compatibility of EU measures applying UN sanctions on individuals with human rights - the applicants' position was that the acts should have been annulled as incompatible with the EU's human rights principles and obligations. Indeed, the CJEU in a groundbreaking decision found that the relevant Regulation was incompatible with the right to effective judicial protection as it imposed restrictions on the applicants without having previously allowed them to be heard or to exercise their rights to the defence.

The decision in Kadi has been instrumental in taking the fundamental rights jurisprudence within the Union's legal system to another level. With this decision, it became evident that EU acts are directly reviewable vis-à-vis their compatibility with international standards of human rights. These cases were also the first step in introducing, at least partially, the CFSP into the jurisdiction of the CFSP.

Indeed, following Kadi, ${ }^{105}$ the gap in the CJEU's jurisdiction was partially rectified by the Lisbon Treaty with the provisions of Article 275 TFEU. The CJEU now has jurisdiction in respect of CFSP to ensure that it remains distinct from other EU policies (Article 40 TEU) and for judicial review under Article 263 if the measure at stake is of a restrictive effect on a natural or legal person.

The CJEU has since found several CFSP measures to be incompatible with human rights. In Bank Mellat ${ }^{106}$ at first instance, the GCEU decided a judicial review claim brought by a bank of which the assets and funds were frozen following a series of Council decisions and Regulations

\footnotetext{
${ }^{102}$ S. Griller, 'The Court of Justice and the Common Foreign and Security Policy', in A. Rosas, E. Levits and Y. Bot (eds), Court of Justice of the European Union - Cour de Justice de l' Union Européenne, The Court of Justice and the Construction of Europe: Analyses and Perspectives on Sixty Years of Case-Law - La Cour de Justice et la Construction Européenne: Analyses et Perspectives de Soixante Ans de Jurisprudence (The Hague TMC Asser Press, 2013), 675-692.

103 Joined Cases C-584/10 P, C-593/10 P and C-595/10 P Commission and Others v Kadi [2013] ECR, Case C402/05 P and C-415/05 P Kadi v Council [2008] E.C.R. I-6351.

104 Ibid.

105 Ibid.

${ }^{106}$ Case T-496/10 Bank Mellat v Council January 29, 2013.
} 
that placed the bank on a list of entities involved in Iranian nuclear proliferation. The bank's claim included the arguments that the Council had not given any reasons for its decision, that there was an error in the assessment of whether the bank should have been included in the list and that the Bank's right to property was disproportionately restricted. The GCEU annulled the relevant act as far as the applicant was concerned since there were no reasons given by the Council and the Council had not supported its decision with any evidence. The GCEU also stated that the principle of effective judicial protection must be applied within the CFSP framework as a safeguard for fundamental rights. This decision was upheld by the CJEU upon appeal which made direct reference to Article 47 of the EU Charter of Fundamental Rights regarding the right to effective judicial protection and held that:

"it must be borne in mind that the effectiveness of the judicial review guaranteed by Article 47 of the Charter of Fundamental Rights of the European Union requires, in particular, that the Courts of the European Union ensure that the decision, which affects that person or entity concerned individually, is taken on a sufficiently solid factual basis."107

With the submission of the CFSP action to the CJEU's scrutiny, there is a developing jurisprudence of the CJEU on the relation of fundamental rights with the CFSP. Fundamental rights concerns as to the restrictive measures have been accepted as reasonable grounds of review. ${ }^{108}$ In Tomana ${ }^{109}$ the GCEU assessed the legality of a Council Decision on freezing the funds of persons in view of the situation in Zimbabwe on the basis of the well-established proportionality test ${ }^{110}$ and found that the measures were justified given the concern that EU

\footnotetext{
${ }^{107}$ Case C-176/13 P Council of the European Union v. Bank Mellat ECLI:EU:C:2016:96

${ }^{108}$ Case T-187/11 Trabelsi and Others v Council [2013] ECR 0.

${ }^{109}$ Case T-190/12 Johannes Tomana and other v. Council (2013), Judgment of the General Court (Eighth Chamber) 22 April 2015.

${ }^{110}$ Proportionality is a general principle of EU law recognised explicitly in Article 5(4) TEU which provides that Union action should not go beyond what is necessary to achieve the objective of the Treaties, a principle which must be respected by all EU institutions by virtue of Protocol (No 2) on the Application of the Principles of Subsidiarity and Proportionality. According to the landmark case on this issue Case C-331/88 R v. Minister for Agriculture, Fisheries and Food, ex parte Fedesa [1990] ECR I-4023, the restrictive measure must be appropriate and necessary in order to achieve the objectives legitimately pursued by the act, the act must be the least restrictive available to the institution and the disadvantages caused must not be disproportionate to the objective pursued. According to Article 52 of the Charter of Fundamental Rights, any limitation of fundamental rights must also respect this principle of proportionality, in that they must be necessary and genuinely meet objectives of general interest recognised by the Union or the need to protect the rights and freedoms of others.
} 
institutions had on the situation in Zimbabwe and also having in mind that the measures were temporary. The applicants appealed this decision, but the CJEU found their claim inadmissible including their invoked ground of appeal for violation of the proportionality principle by the GCEU. ${ }^{111}$

These indicative examples of case law demonstrate the increased ability of individuals to bring claims against EU institutions before the CJEU for CFSP measures for incompatibility with human rights following the Lisbon Treaty, even if the assessment of finding a violation may not always be positive. This is undoubtedly an important step forward for the protection of human and fundamental rights within the legal and judicial system of the Union.

The developments in the Treaties and case law alike have not, however, given full access to justice to individuals, in relation to challenging CFSP measures vis-à-vis human rights. The Court does not scrutinise either the decision-making procedure or the legal basis of the CFSP measure. ${ }^{112}$ The CJEU can only review acts in the CFSP field as to their compatibility with human rights when those are classified as 'restrictive measures' as per the case law above, and as such it lacks general jurisdiction to rule on whether the CFSP acts respect human rights. ${ }^{113}$

One more issue related to the EU's human rights responsibilities regarding the CFSP and its accountability under the judicial review procedure, is whether the European External Action Service is an institution of the EU which is in any case accountable before the EU Courts (the topic of the EU as an international legal actor and its relationship with international human rights law is examined in further detail in Part III). ${ }^{114}$

The European External Action Service is a body established to assist the High Representative of the Union for Foreign Affairs and Security Policy. It was established with a Council decision in 2010 and its key role is the assistance to the EU's High Representative in the fulfilment of her

\footnotetext{
${ }^{111}$ Case C-330/15 P Johannes Tomana v. Council ECLI:EU:C:2016:96.

112 B. van Vooren and R.A. Wessel, EU External Relations Law - Texts, Cases and Materials (CUP 2014) 379.

${ }^{113}$ M. Brkan, 'The Role of the European Court of Justice in the Field of Foreign and Security Policy after the Treaty of Lisbon: New Challenges for the Future', in P.J. Cardwell (ed), EU External Relations Law and Policy in the PostLisbon Era (The Hague: T.M.C. Asser Press, 2012) 100.

${ }^{114}$ M. Gatti, 'Diplomats at the Bar: the European External Action Service before EU courts' (2014) 39(5) ELR 664681, 667.
} 
tasks in external and diplomatic policy. ${ }^{115}$ The EEAS is functionally autonomous, separate from the Council and the Commission with the 'legal capacity necessary to perform its tasks and attain its objectives', 116 while it is under the control of the High Representative who in turn is accountable to the EU's institutions. ${ }^{117}$ The EEAS is also instrumental in the activities within the Permanent Structured Cooperation (PESCO), forming part of the secretariat related to it. Within the PESCO framework under Article 42(6) TEU member states participate in a form of permanent structured cooperation in the field of defence by sharing capabilities for common goals and they adhere to binding commitments. ${ }^{118}$ According to Article 7 of the Decision ${ }^{119}$ establishing PESCO, the EEAS contributes in the assessment of PESCO projects.

Indeed, the legal nature of the EEAS has been described as sui generis ${ }^{120}$ in the sense that its legal status and position within the spectrum of EU law is not clearly defined as it is formally dissimilar from the rest of EU institutions and bodies. ${ }^{121}$ This lack of clarity creates a further obstacle to the accountability of the EU in relations to its CFSP action.

While CFSP has now to some extent been brought under the ambit of scrutiny by the EU courts, after the introduction of Article 275 TFEU, the truth is that such scrutiny can only be applied to 'restrictive measures'. These are sanctions related measures against natural or legal persons for the purposes of a common foreign policy. ${ }^{122}$

There is no general procedural vehicle for the challenge of CFSP action vis-à-vis human rights while the status of the EEAS also remains insufficiently defined. This evidently leaves an important gap, given the human rights related risks entailed within CFSP/CSDP action, such as

${ }^{115}$ Council Decision 2010/427/EU of 26 July 2010 establishing the organisation and functioning of the European External Action Service, OJ 2010, No. L201/30.

${ }_{116}$ Article 1(2) of Council Decision 2010/427/EU.

117 B. van Vooren and R. Wessel, EU External Relations Law (CUP 2014) 21.

118 COUNCIL DECISION (CFSP) 2017/2315 of 11 December 2017 establishing permanent structured cooperation (PESCO) and determining the list of participating Member States.

${ }^{119}$ Ibid.

${ }^{120}$ Missiroli A., 'The New EU Foreign Policy System after Lisbon: A work in Progress' (2010) 15 European Foreign Affairs Review, 427-452.

${ }^{121}$ Van Vooren B., 'A Legal Institutional Perspective on the European External Action Service' (2011) 48 CMLRev, 475-502, 500-501.

${ }^{122}$ Restrictive measures are not explained in greater detail in the wording of the Treaties beyond measures taken through Council Decisions by a qualified majority proposed by the High Representative against natural or legal persons, groups and non-state actors for the purposes of foreign policy as per Article 215 TFEU and so far the case law has concentrated on sanction-related measures. 
peacekeeping operations and diplomatic missions, which remain fully outside the ambit of judicial review. The 'restrictive measures' exception also does not go any further than in fact codifying the rule laid down in Kadi for sanctions and the construction of the Treaties' provisions leave little room for an expansive interpretation by the Courts for the term 'restrictive measures. Therefore, there is a need for further expansion of the Courts' competence to judge on matters of CFSP as to their compatibility with human rights, particularly within the review of legality procedure, while it would also be desirable for the Courts to expand the limit of the term 'restrictive measures', to measures with other objectives beyond sanctions in order to establish the judicial review procedure as a mechanism for the protection of human rights against violations by EU institutions.

\section{Geographical scope of judicial review and human rights}

Where the Union is acting as an international legal actor, something which is further examined in Part III, the Union may act well beyond its territorial borders. The question which arises is whether the judicial review procedure is available to challenge action taken by the EU outside its territorial borders as an international actor based on Article 21 of the TEU, vis-à-vis human rights violations that may arise.

In Commune de Champagne ${ }^{123}$ the ECJ held that an act of the institutions cannot create rights and obligations outside the territory of the Union, as defined at the time in Article 299 TEC and as it is defined today in Article 52 TEU and Article 355 TFEU. That does not mean that no person located outside the Union can bring a claim. If a person is outside the EU geographical scope, they may still bring an action against a Union institution. In Tomana the General Court stated that where the applicant is a person not located in the EU, it is required that the measure challenged have effects on the applicant's situation within the Union, for an action to be admissible. ${ }^{124}$

\footnotetext{
${ }^{123}$ Case T-212/02, Commune de Champagne [2007] ECR II-2023.
}

124 cf. Tomana (n.109). 
In Salemink ${ }^{125}$ the CJEU was of the view that EU law applies where the Member State has sovereignty. This case regarded a request for a preliminary ruling, on whether the EU legislation applied to the Netherlands' continental shelf, where the Netherlands had functional sovereignty based on Article 80 of the United Nations' Convention on the Law of the Sea. In the same case, the Advocate General's Opinion ${ }^{126}$ had elaborated on the question of the application of EU law and by extent, of obligations deriving from EU law, from another viewpoint. The Opinion of the Advocate General refers to 'lawful exercise of competence' as opposed to 'sovereignty'.

What follows from this decision, is that states are obliged to enforce EU law where they have sovereignty according to international law. However, neither the CJEU's decision, nor the AG's Opinion dealt with the question of the obligations of the EU institutions themselves, as the case concerned state obligations to apply EU law.

Furthermore, one may compare the judgment and the Opinion in Salemink with the approach taken by the ECtHR regarding the application of the ECHR outside the territorial scope of the Contracting Parties. The matter of extraterritoriality in the ECHR has been examined Loizidou. ${ }^{127}$ The ECtHR made an important deliberation as to ascertaining whether a contracting party is bound by ECHR obligations outside its own territory: the decisive factor is whether the contracting party has effective control on the territory in question. If such effective control exists, then the relevant state is bound by the ECHR.

The Loizidou decision is significant for setting down the doctrine of extraterritoriality. Extraterritoriality and 'effective control' have not been given a narrow meaning within the case law of the ECtHR. In Al Skeini, ${ }^{128}$ for example, the ECtHR went a step further than effective control on a territory as such. It held that when the contracting party is exercising physical control through apprehension or detention. In this case, the ECtHR found that the Convention still applied to the UK's extraterritorially in Iraq, following the detention of the applicants. ${ }^{129}$

125 Case C-347/10 Salemink v Raad van Bestuur van het Uitvoeringsinstituut Werknemersverzekeringen [2012] 2 CMLR 6

${ }^{126}$ Ibid, $\$ 55$ of the Advocate General's Opinion.

${ }^{127}$ Loizidou v. Turkey (Preliminary Objections) (App no. 16318/89) ECtHR 24 October 1995 (1995) 20 EHRR 99.

${ }^{128}$ Al-Skeini v United Kingdom (merits and just satisfaction) (App No. 55721/07) ECtHR 7 July 2011 [GC] (2011) 53 EHRR 18.

129 These criteria were also reaffirmed by the ECtHR in Chagos Islanders $v$ United Kingdom (Admissibility) (App No. 35622/04) ECtHR 11 December 2012 (2013) 56 EHRR SE15. 
Therefore in comparison to the ECtHR, which holds parties accountable where they have effective control over a territory, even illegally, the EU has so far only accepted the application of its treaties where the Member States exercise lawful sovereignty. On a theoretical level, the distinction between the two lies in the different criteria set down by the case law of the two Courts - the CJEU looking for de jure sovereignty, be it partial or limited, and the ECtHR requiring de facto control. In practice, the distinction lies in the fact that the ECtHR as such expands the scope of application of the Convention thus allowing more claims to be brought before it, while the CJEU remains more formalistic and as such limiting access to it.

The judgment and Advisory Opinion in Salemink as well as the case law also leave a grey area in cases where sovereignty is not exercised de jure. Furthermore, the case law has also not yet addressed the situation where the EU institutions are taking direct action. This therefore raises the question of whether the EU's institutions are bound by EU law when they take measures which affect people who are not within the EU's territory. The question of extraterritorial obligations of the EU itself, and particularly whether the judicial review procedure is applicable to acts that have external effect remains unresolved. ${ }^{130}$

In Parliament v. Council (Al Qaeda), ${ }^{131}$ the CJEU examined an action for annulment by the Parliament claiming that Regulation (EU) No 1286/2009, which was passed for the purposes of combating terrorism should have been passed under Article 75 TFEU and not Article 215 TFEU. Acts that relate to the combating of terrorism fall under the CFSP heading, and the CJEU made the following observation:

"It is to be noted that the duty to respect fundamental rights is imposed, in accordance with Article 51(1) of the Charter of Fundamental Rights of the European Union, on all the institutions and bodies of the Union. In addition, under both Article 75 TFEU and Article 215(3) TFEU, the acts referred to in those articles are to include necessary provisions on legal safeguards."

\footnotetext{
${ }^{130}$ L. Bartels, 'The EU's human rights obligations in relation to policies with extraterritorial effects' (2014) 25(4) EJIL, 1071-1091, 1089.

${ }^{131}$ Case C-130/10 Parliament v. Council (Al Qaeda) ECLI:EU:C:2012:472.
} 
Bartels mentions that the CJEU had general CFSP measures in mind, while since CFSP measures also have extraterritorial application, the obligations of the EU institutions when applying such measures are binding extraterritorially. ${ }^{132}$ Nevertheless, the position voiced by the CJEU in this case may also be seen as a repetition of the commitment of the EU to human rights when acting internationally, as it is expressly laid down in Article 21 TEU, without necessarily establishing the reviewability of general CFSP measures.

Therefore, the CJEU's statements on the matter have not been clarifying. The CJEU's stance regarding the submission of extraterritorial action to the process of judicial review may be compared with its stance regarding the effects of extraterritorial action under the action for damages procedure provided for by Article 340 TFEU.

Conclusively, the exact scope of application of the procedure of judicial review is unclear thus allowing institutions and competence areas to slip out of the CJEU's scrutiny vis-à-vis human rights. Certain bodies and institutions of the Union, such as the European External Action Service remain in a grey area as to their status and their accountability. Similarly, as it was demonstrated with the case of Mallis, ${ }^{133}$ acts of the Union within the European Stability Mechanism are not subject to review. Therefore, the CJEU has a crucial role in ascertaining in which areas of EU action the judicial review procedure may function as a remedy.

In addition, the criteria for the locations where Union law and the human rights related obligations of EU institutions stemming from EU law may apply have not been set. This is of utmost importance in the relationship between judicial review and human rights. The case law of the CJEU does not clarify how human rights obligations may apply to the EU beyond its own territory. The case law does not address the need for a coherent legal framework as the Union's activities at the international legal level grow. The conclusive observation for this Section is that there is the need for both the CJEU and other EU institutions to define the scope of application of Article 263 vis-à-vis human rights violations. This could institute a proper legal regime where Union acts that have both an internal effect within the Union and an external effect reaching beyond the Union's borders may scrutinised by the CJEU. This must be done in an inclusive and

\footnotetext{
132 cf. Bartels (n.130) 1076.

133 cf. Konstantinos Mallis (n.91).
} 
open - rather than a restrictive - way so that the Union's judiciary may function as a true and effective forum for the protection of human rights.

\section{E. Conclusion}

The use of the action for annulment as a remedy for human rights violations by the EU is a complicated matter with limited success for individual applicants. This is supported by the following findings.

Given the finding of the significant gap left by the non-accession, it is necessary to turn to the EU's legal system to examine how human rights victims may claim redress against the EU. The first remedy that ought to be examined in this framework is the one provided by an action for annulment. Firstly, because the action of annulment is directly related to fundamental rights $-\mathrm{a}$ violation of a fundamental right protected by EU law constitutes an act illegal and subject to annulment. Secondly, annulment is the direct, immediate path of attacking the violating act with the purpose of rendering it annulled and ineffective, as if it has never existed.

This relevance of the procedure of judicial review and the remedy of annulment is undermined by two problems. The standing requirements have been interpreted so very strictly by the CJEU to the point that individual applicants can rarely fulfil them where the measure in question is not directly addressed to them. This is against the principle of effective judicial protection; the strict interpretation renders the remedy inaccessible thus making the protection of human rights offered by EU law fall short of the standard required for effective judicial protection.

On a second level the procedure of judicial review is not applicable to all areas of EU action, something that would be the case if the EU were to succeed to the ECtHR. Most importantly the gap is noticed in the area of the Common Foreign and Security Policy where the CJEU may review acts only in terms of competence or where they are restrictive measures against individuals. No general jurisdiction exists over the CFSP. That is regrettable given that this area of EU action has an intensive interplay with human rights given that it concerns acts taken in areas under conflict, with vulnerable populations. 


\section{Chapter 3}

\section{Alternatives to the ECHR and the Judicial Review Remedies}

\section{A. Introduction}

The present Chapter will close the first Part of the thesis of which the subject matter is the remedies deficit for human rights violations by the EU through its institutions, bodies and agencies.

The Sections to follow explore certain existent 'alternatives' to obtain scrutiny and remedies for human rights violations by the Union, given the absence of accession to the ECHR and the severe shortcomings of the judicial review procedure and the remedy of annulment. As a first alternative, this Chapter will explore the use of the doctrine of direct effect and the preliminary reference procedure as an alternative route to annulment in order to achieve the remedying of a human rights violation by the EU. Secondly, Section $\mathrm{C}$ of the present Chapter will explore the use of the procedure of the plea of illegality as an alternative means to access remedies for human rights violations before the EU courts.

Section D will explore some existent mechanisms which may be viewed as alternative to the legal problems posed by non-accession to the European Convention on Human Rights and the ineffectiveness of the judicial preview procedure. More specifically Section D will consider two specific bodies set up for the purposes of safeguarding human rights vis-à-vis specific areas of EU action the Complaints Mechanism and the Fundamental Rights Officer of Frontex and the EULEX Panel in Kosovo.

\section{B. The indirect remedies provided by direct effect and preliminary references}

As it has been mentioned by the Court in $U P A,{ }^{1}$ the existence of the preliminary reference procedure is an alternative which may be used to make up for some shortcomings of the judicial review procedure in the effectiveness of judicial protection within EU law, particularly the problems posed by standing as described above.

${ }^{1}$ Case C-50/00P UPA v. Council [2002] ECR I-6677. 
The question which concerns the present section is whether the doctrine of direct effect in combination with preliminary references may indeed function as an alternative remedy to judicial review or the ECHR remedies, where an individual feel that their rights have been violated by the EU. The hypothesis is that indeed the doctrine and the procedure may be used in that way. Nevertheless, it must be kept in mind that the preliminary reference procedure is not a panacea for the flaws of other procedures, and it must not be perceived as such. The indirect nature of the procedure underlines that it is not a remedy that the individual may readily use, and it is not meant to be used as a direct attack on the act an individual purport has violated her rights.

Article 267(1) provides that the CJEU has jurisdiction to give preliminary rulings on the interpretation of the Treaties or on the validity of the act of Union acts, bodies, agencies and institutions. Such preliminary rulings are requested by national courts, when a question regarding the interpretation or validity of Union law is raised before them, before they rule on the dispute. ${ }^{2}$ Where the national court's decision is not subject to judicial remedy the court must make a preliminary ruling request, while if it is an inferior national court, the procedure is optional. ${ }^{3}$ The nature of the act is irrelevant when it comes to a review of validity within the framework of a preliminary reference and all acts regardless of bindingness may be reviewed. ${ }^{4}$

The practical aspect of the preliminary reference procedure is rooted on the doctrine of direct effect. The first landmark case of the CJEU Van Gen den Loos, ${ }^{5}$ marks the beginning of the formation of the role of direct effect in the protection of individual rights within the scope of EU law. The Court said that Article 177 of the EEC Treaty (now Article 267 TFEU) has as its object the uniform interpretation of the Treaty by national courts and tribunals. This confirms that EU law is an authority which can be invoked by nationals before those courts and tribunals. Van Gend en Loos is probably the most famous of all the CJEU's rulings undoubtedly because of the

\footnotetext{
2 Article 267(2) TFEU.

3 Article 267(3) TFEU.

${ }^{4}$ Case C-491/01 British American Tobacco (Investments) and Imperial Tobacco [2002] ECR I - 11453, Case C343/09 Afton Chemical [2010] I-7023.

${ }^{5}$ Case 26/62 NV Algemene Transport-en Expeditie Onderneming van Gend en Loos v. Nederlandse Administratie der Belastingen [1963] ECR 1.
} 
breakthrough it brought in the creation of the EU legal order. ${ }^{6}$ Direct effect means that EU law permeates the national legal system to the effect that individuals are conferred rights by that law. ${ }^{7}$

Therefore, it is possible for an individual, while in litigation before a national court, to contest that a measure taken by the Member State, which in turn implements or applies an EU measure is in contradiction of a human or fundamental right protected by EU law. In that case, the norm of EU law invoked must be sufficiently clear, precise and unconditional to be invoked by an individual $^{8}$ and it can be relied on by an individual where it sets out an obligation in unconditional and unequivocal terms. ${ }^{9}$ Certain general principles of EU law, related fundamental and human rights, such as the principle of equal treatment have been awarded direct effect, both in vertical situations of public law litigation and horizontal situations of private law litigation. ${ }^{10}$ The provisions of the Charter of Fundamental Rights have been invoked to challenge EU or domestic law without the CJEU having expressly referred to the matter of direct effect. ${ }^{11}$

The number and the nature of proceedings before national courts in which EU law is implicated is impossible to ascertain, due to the different approaches and procedures available in domestic laws. The question of compatibility of the EU act applied by the state with human rights can also

\footnotetext{
${ }^{6}$ M. Rasmussen, 'Revolutionizing European Law: A History of the Van Gend en Loos judgment' (2014) 12 ICON 136, J.H.H. Weiler, 'Van Gen den Loos: The Individual as Subject and Object and the Dilemma of European Legitimacy' (2014) 12 ICON 94.

${ }^{7}$ K. Lenaerts and T. Corthaut T 'Of Birds and Hedges: the Role of Primacy in Invoking Norms in EU law' (2006) 31 ELR 287, S. Robin - Olivier, 'The Evolution of Direct Effect in the EU: Stocktaking, Problems, Projections' (2014) 12 ICON 165.

${ }^{8}$ Ibid, Lenaerts and Corthaut, 311 and P. Pescatore, 'The Doctrine of 'Direct Effect': An infant disease of Community law' (1983) 8 ELR 155, 176-177.

${ }^{9}$ Cases C-246-249/94 Cooperative Agricola Zootecnica S Antonio v. Amministrazione delle Finanze dello Stato [1996] ECR I-4373, Case C-317/05 Phol Boskamp GmbH \& Co KG v. Gemeinsamer Bundesausschuss [2006] ECR I-10611, C-194/08 Gassmayr v. Bundesminister für Wissenschaft und Forschung EU:C:2010:386.

${ }^{10}$ Case C-144/04 Mangold v. Rudiger Helm [2005] ECR I-9981, Case C-555/07 Kucukdeveci v. Swedex \& Co KG EU:C:2010:365. There are conflicting views as to whether the extension of direct effect of general principles is a positive step in EU law or a cause of legal uncertainty. See P. Cabral and R. Neves, 'General Principles of EU law and Direct Effect' (2011) 17 EPL 437, S. Robin - Olivier, 'The Evolution of Direct Effect in the EU: Stocktaking, Problems, Projections' (2014) 12 ICON 165, M. de Mol, 'The Novel Approach of the CJEU on the Horizontal Effect of the Principle of Non-Discrimination' (2011) 18 MJECL 109.

${ }^{11}$ See for example, Case C-617/10 Alkagaren v. Hans Akerberg Fransson EU:C:2013:105.
} 
be appear in innumerable and varied proceedings across the EU Member States. ${ }^{12}$ It is therefore beyond the purposes of this thesis to identify these procedures.

Nevertheless, it is certain that where there are doubts as to the validity of an EU act vis-à-vis a fundamental rights rule with direct effect the national courts will stumble upon the issue of jurisdiction. This will force the national courts to refer the matter to the CJEU if they believe there is indeed a question of invalidity. In Foto -Frost ${ }^{13}$ it was clarified that under Article 267 TFEU the CJEU has exclusive jurisdiction to declare an act invalid where the validity of a Union act is challenged before national courts.

National courts may only be confined to the review of national measures. For example, a case arose before the German Courts in relation to the CSDP Operation Atalanta, ${ }^{14}$ where German personnel had arrested, detained and transferred nine suspects of piracy. The matter reached the Administrative Appeal Court of North Rhine - Westfalia (Obervelwaltungsgericht NordrheinWestfalen). The court accepted that the EU was responsible for the operation yet held that the acts in question were attributable to Germany. A violation of Article 3 of the ECHR was found due to the surrender of the suspects by Germany to Kenyan authorities. In this case, the measure which was invalidated and found unlawful was a national measure even though it derived from a measure of the EU. ${ }^{15}$

This leads to one conclusion or assumption in relation to the substantive remedies available for violations of human rights by EU acts. Direct effect does not allow individuals to obtain remedies directly against the EU institutions before national courts. Although direct effect means that national courts effectively act as EU courts, the institutions of the EU are not brought before justice and the remedy is not obtained directly from the EU institution. It is the national authority which is found liable with the EU staying safely outside the reach of the judgment's

\footnotetext{
${ }^{12}$ For example, in English law, it may arise under a matter of incompatibility of a national action with the ECHR pursuant to Section 6 of the Human Rights Act 1998. In Cyprus, human rights have a horizontal effect and may form a cause of action in private law, whereas the compatibility of a legal rule with the Constitution which contains both provisions on human rights and an express provision for the supremacy of EU law may be invoked at any stage of any proceedings and any court may rule on the matter.

${ }^{13}$ Case C 314/85 Firma Foto - Frost v. Hauptzollamt Lubek -Ost [1987] ECR 4199.

${ }^{14}$ Council Joint Action 2008/851/CFSP on a European Union military operation to contribute to the deterrence, prevention and repression of acts of piracy and armed robbery off the Somali coast [2008] OJ L 301/33.

15 J. Heliskoski, 'Responsibility and Liability in CSDP Operations' in S. Blockmans and P. Koutrakos (eds), Research Handbook on CFSP/CSDP (Elgar Publishing 2016).
} 
repercussions. Holding the national authority liable cannot make up for direct challenges against EU institutions or rectify completely the fact that annulment based on Article 263 TFEU is a remedy which has stringent requirements and limited scope. Similarly, it cannot substitute the scrutiny of EU action that accession to the ECHR would entail, or the important substantial remedies offered by the ECHR system which would have political ramifications within the EU's legal order.

Despite the above, direct effect creates another means of indirect access for individuals to EU courts. That is in order to obtain a declaration of invalidity, through Article 267 TFEU. The EU Courts have accepted this as an alternative to Article 263 because the standing test does not apply. In $\mathrm{Rau}^{16}{ }^{16}$ the Court said that where the applicant seeks to contest the legality of a measure in national courts and use the preliminary ruling procedure in due course without needing to clarify whether they would have standing under the action for annulment. However, where the applicant could have standing under Article 263, the validity of the Union act will not be examined by the Courts, ${ }^{17}$ and even more so Article 267 cannot function as an alternative where the applicant has missed the two-month deadline dictated by Article 263(4). ${ }^{18}$

The Court's view is that Article 267, along with Article 277 compliment the judicial review procedure by providing a complete system of judicial protection. In Inuit, ${ }^{19}$ the Court stated:

"To that end, the FEU Treaty has established, by Articles 263 and 277, on the one hand, and Article 267, on the other, a complete system of legal remedies and procedures designed to ensure judicial review of the legality of European Union acts, and has entrusted such review to the Courts of the European Union (see Case 294/83 Les Verts v

16 Cases C-133-136/85 Walter Rau Lebensmittelwerke v. Bundesanstalt für Landwirtschaftliche Marktordnung [1987] ECR 2289.

${ }^{17}$ Case C-188/92 TWD Textilwerke Deggendorf GmbH v. Germany [1994] ECR I-833.

${ }^{18}$ Case C-178/95 Wiljo, EU:C:1997:46, paragraphs 15 to 25; of 15 February 2001, Nachi Europe, C-239/99, EU:C:2001:101, paragraphs 29 to 40; and of 22 October 2002, National Farmers' Union, C-241/01, EU:C:2002:604, paragraphs 34 to 39). In numerous other cases, the Court has held that it was not established that the action would unquestionably have been admissible (see, inter alia, to that effect, judgments of 23 February 2006, Atzeni and Others, C-346/03 and C-529/03, EU:C:2006:130, paragraphs 30 to 34; of 8 March 2007, Roquette Frères, C-441/05, EU:C:2007:150, paragraphs 35 to 48; of 29 June 2010 , E and F, C-550/09, EU:C:2010:382, paragraphs 37 to 52; of 18 September 2014, Valimar, C-374/12, EU:C:2014:2231, paragraphs 24 to 38; and of 5 March 2015, Banco Privado Português and Massa Insolvente do Banco Privado Português, C-667/13, EU:C:2015:151, paragraphs 27 to 32

${ }^{19}$ C-398/13 P Inuit Tapiriit Kanatami v European Commission EU:C:2015:535. 
Parliament [1986] ECR 1339, paragraph 23; Unión de Pequeños Agricultores v Council, paragraph 40; Reynolds Tobacco and Others v Commission, paragraph 80; and Case C-59/11 Association Kokopelli [2012] ECR, paragraph 34).”

The preliminary rulings procedure has been used to invalidate EU acts on fundamental rights grounds. In Test-Achats ${ }^{20}$, a preliminary ruling was given by the EU regarding the validity of Directive 113/2004. This insurance-related directive aimed at the elimination of unequal treatment between men and women in insurance schemes, but in its Article 5(2) it allowed an indefinite transition period for the Member States. The Court found that this ran the risk of perpetuating the inequalities between men and women and thus partially annulled the Directive as incompatible with Articles 21 and 23 of the Charter which provide for equality between men and women.

In Digital Rights Ireland $^{21}$ the CJEU annulled the Data Retention Directive aimed at the harmonisation of Member States' rules on the retention of data. This Directive provided that electronic communications and public communication providers should retain traffic and location data for counter-terrorism purposes, which according to the CJEU was found contrary to the rights of private life and personal data found in Articles 7 and 8 of the Charter respectively. This was because the Directive did not follow the proportionality principle - there was no objective criterion by which the authorities' interference with personal data would be limited to serious crimes.

The preliminary ruling procedure has been useful in both invalidating as well as interpreting EU acts and their conformity with fundamental rights. ${ }^{22}$ It has been characterised as the most effective tool for the guarantee of effective judicial protection. ${ }^{23}$ Nevertheless, one must bear in mind that according to the provision of the Article 267, only Courts not subject to further judicial

${ }^{20}$ Case C-236/09 Association Belge des Consommateurs Test-Achats ASBL and Others $v$ Conseil des ministres [2011] ECR I-00773

${ }_{21}$ Joined Cases C-293/12 and C- 594/12 Digital Rights Ireland Ltd v Minister for Communications, Marine and Natural Resources and Others and Kärntner Landesregierung and Others. Requests for a preliminary ruling from the High Court (Ireland) and the Verfassungsgerichtshof. ECLI:EU:C:2014:238.

${ }^{22}$ D. Dusterhaus 'Procedural primary and effective judicial protection: a trilogue', (2016) 23(2) Maastricht Journal of European and Comparative Law, 317-331, 326.

${ }^{23}$ M. Safjan and D. Dusterhaus, 'A union of effective judicial protection: Addressing a multi-level challenge through the lens of Article 47 CFREU', 33 YEL (2014) 3-40, 38. 
remedy are obliged to make a preliminary reference. This means that the preliminary ruling procedure is not triggered without any qualifications as a simple alternative to the judicial review process, while individuals have no option of challenging the failure of a national court not to make a request for a preliminary ruling. ${ }^{24}$ This therefore reduces the role of individuals and their ability to challenge EU acts and rather renders national courts responsible for guarding the principle of effective judicial protection in the EU. ${ }^{25}$

The preliminary ruling procedure consequently cannot substitute the role of judicial review and it is not considered a direct remedy to be sought by individual applicants against the EU for human rights violations. Firstly, this procedure is not readily available to individual applicants. The initiative for triggering the procedure comes from the national court adjudicating the matter. ${ }^{26}$ While the litigants before the national court may file applications for the case to be referred to the CJEU, it is impossible for the litigants themselves to oblige the national court to raise the preliminary question. ${ }^{27}$ The preliminary ruling procedure is therefore not a means for individual applicants to obtain redress within the framework of a dispute that may be pending before a national court given that the CJEU will not be able to rule on the validity of a Union act, even if a question has been raised before the national court unless the national court submits the question before the CJEU. ${ }^{28}$

Where the national litigation involves claims against a Member State, the Member State may avoid the preliminary reference by simply accepting the individual's claim against it. ${ }^{29}$ In litigation at a national level, a high level of effort must be made, for the individual applicant to formulate the case in a way to 'induce' the national court to refer the matter to the CJEU. ${ }^{30}$ This would require tactics as to the structure of the case, for example ensuring there is no right of

\footnotetext{
${ }^{24}$ Case C-213/13 Impresa Pizzarotti EU:C:2014:2067

${ }^{25}$ C. Lacchi, 'Multilevel judicial protection in the EU and preliminary references' (2016) CMLRev 53(3) 679-707, 687.

${ }^{26}$ K. Lenaerts, I. Maselis, K. Gutman and J.T. Nowak, EU Procedural Law (OUP 2014) 468.

${ }^{27}$ Case 44/65 Singer [1965] E.C.R. 965, 970.

${ }^{28}$ Joined Cases C-276/05 and C-377/05 A. Brunsteinder and Autohaus Hilgert [2006] ECR I - 11383, Joined Cases C-188/10 and C-189/10 Melki and Abdeli [2010] ECR I - 5665.

${ }^{29}$ M. Broberg, 'Preliminary References as a Means for Enforcing EU law' in Jakab A. and Kochenov D., The Enforcement of EU law and values, (OUP 2016), 100.

${ }^{30} \mathrm{Ibid}, 105$.
} 
appeal from the national court seized, or formulating the case to argue that a reference is necessary so as to depart from a clear ruling previously established by the Union judicature. ${ }^{31}$

The declaration of nullity means that the act annulled is considered never to have existed because it is a direct attack on the act. The declaration of invalidity renders the act inapplicable or inoperative, without annulling or eradicating its existence, but rather ceasing its operation. As Lenaerts et al point out ${ }^{32}$ both the declaration of invalidity and the declaration of nullity have erga omnes and ex tunc effect, going back to the date that the act took effect, however through the latter declaration the Court does not proceed to the eradication of the act. The difference is formal rather than substantial. However, the action for annulment as per Article 263(4) requires the application to be brought within two months of the publication of the measure or when the applicant takes knowledge of it. This means that in the event of annulment, the duration of application of the measure in question will be relatively limited or at least the damage caused to individuals will be more easily identifiable within a known timespan.

A preliminary reference may be made at any time given that it is subject to the existence of a domestic law dispute. As a declaration of invalidity is erga omnes and ex tunc, it is unclear how far in the past go the effects of the invalidation - for that reason the CJEU may limit the temporal effects of the invalidation on the basis of the particular circumstances of the case, for the purposes of legal certainty. ${ }^{33}$ Persons who were not parties to the procedure from which the ruling has emanated may rely on the invalidity of the act if they have pending proceedings against actions based on the invalidated act before the declaration of invalidity. ${ }^{34}$

However, a declaration of invalidity cannot, for reasons of legal certainty, change previous results of national court procedures and neither can it rectify any damage caused to individuals who have not resorted to justice. Actual damage caused by an act violating human rights norms which can only be effectively rectified by an effective application for an action for damages (See Part II), where the applicant will claim remedies for the damage caused to their rights by the unlawful act. This role is not something that can be fulfilled by this procedure. For that reason,

\footnotetext{
31 Ibid.

32 cf. Lenaerts et al (n.26) 476

${ }^{33}$ Ibid, 476, 477. See particularly Case C-333/07 Société Régie Networks [2007] ECR I-10807.

${ }^{34}$ Case C-228/92 Roquette Frères ]1994] ECR I-4445.
} 
the preliminary reference procedure cannot be perceived as an effective remedy for human rights violations by EU institutions.

The material scope of Article 267 is also limited in a way very similar to the judicial review procedure. It has been explained in detail in the section dealing with the scope of judicial review in matters of Common Foreign and Security Policy, that Article 275 TFEU precludes the CJEU from having jurisdiction on acts adopted on the basis of the CFSP. ${ }^{35}$ The only express exception is Article 263 proceedings that relate to restrictive measures against natural or legal persons. The CJEU has the jurisdiction to rule on the interpretation of international agreements concluded by the EU which form part of the CFSP ${ }^{36}$ and their validity. ${ }^{37}$ The question that arises is therefore whether the review of validity under Article 267 TFEU may be subject to the same exemption. Before any traces of case law, it was speculated that the wording of Article 275 was quite strict and unequivocal given that it mentions only actions for annulment under Article 263 TFEU to be a possible forum for the review of the legality of CFSP acts. ${ }^{38}$

However, a breakthrough came with the Grand Chamber's decision in PJSC Rosneft Oil Company v Her Majesty's Treasury and Others, ${ }^{39}$ in March 2017. The applicants in the present case were a Russian company which contested restrictive measures that affected it. It did so on a multitude of levels, including an action under Article 263 as well as judicial review proceedings in English law. The High Court of England and Wales, while adjudicating the judicial review proceedings vis-à-vis the national measures implementing the said CFSP actions referred the question to the CJEU as to the legality of the measures. The application involved arguments of fundamental rights violations, with the applicant supporting that certain provisions of Regulation No 833/2014 are not clear and precise means that individuals are not in a position to ascertain unequivocally what their rights and obligations are, while the Member States are obliged to adopt criminal penalties to implement the restrictive measures. That, they maintained, was in breach of the principle of legal certainty and the principle of nulla poena sine lege certa, as

\footnotetext{
${ }^{35}$ See M. Brkan, 'The Role of the European Court of Justice in the Field of Foreign and Security Policy after the Treaty of Lisbon: New Challenges for the Future', in P.J. Cardwell (ed), EU External Relations Law and Policy in the Post-Lisbon Era (The Hague: T.M.C. Asser Press, 2012) 100.

${ }^{36}$ See P. Eeckhout, EU External Relations Law (2 ${ }^{\text {nd }}$ edition, OUP 2011), 498.

${ }^{37}$ Case C-327/91 France v. Commission [1994] ECR I-3641.

38 cf. Lenaerts et al (n.26) 458.

${ }^{39}$ ECLI:EU:C:2017:236.
} 
embodied in Article 7 of the ECHR and Article 49 of the EU Charter of Fundamental Rights. The matter of jurisdiction was raised in relation to the application's admissibility, which the court handled in the following way:

"75 Since the purpose of the procedure that enables the Court to give preliminary rulings is to ensure that in the interpretation and application of the Treaties the law is observed, in accordance with the duty assigned to the Court under Article 19(1) TEU, it would be contrary to the objectives of that provision and to the principle of effective judicial protection to adopt a strict interpretation of the jurisdiction conferred on the Court by the second paragraph of Article 275 TFEU, to which reference is made by Article 24(1) TEU (see, by analogy, judgments of 27 February 2007, Gestoras Pro Amnistía and Others v Council, C 354/04 P, EU:C:2007:115, paragraph 53; of 27 February 2007, Segi and Others v Council, C 355/04 P, EU:C:2007:116, paragraph 53; of 24 June 2014, Parliament v Council, C 658/11, EU:C:2014:2025, paragraph 70; of 12 November 2015, Elitaliana v Eulex Kosovo, C 439/13 P, EU:C:2015:753, paragraph 42, and of 19 July 2016, H v Council and Commission, C 455/14 P, EU:C:2016:569, paragraph 40).

76 In those circumstances, provided that the Court has, under Article 24(1) TEU and the second paragraph of Article 275 TFEU, jurisdiction ex ratione materiae to rule on the validity of European Union acts, that is, in particular, where such acts relate to restrictive measures against natural or legal persons, it would be inconsistent with the system of effective judicial protection established by the Treaties to interpret the latter provision as excluding the possibility that the courts and tribunals of Member States may refer questions to the Court on the validity of Council decisions prescribing the adoption of such measures."

The jurisdiction of the CJEU within Article 267 for the review of validity therefore expands to restrictive measures. However, again this does not mean that the CJEU may rule on the validity of every CFSP measure but rather it should be read in the restrictive way that the exemption of Article 275 puts it for the purposes of judicial review. This development is indeed of importance 
because it is yet another step to bringing CFSP action under review and consequently under the rule of law. ${ }^{40}$

As per Koutrakos, ${ }^{41}$ the first argument of the court was contextual; there is a complementary nature of annulment procedures and preliminary references, in that they form part of an integral system of remedies. Secondly, the argument of the CJEU was textual in that the express reference to Article 263 in Article 275 TFEU did not mean that all other procedures or the preliminary reference procedure were excluded. Thirdly the CJEU held that CFSP acts must be subject to review within the framework of national procedures given that the Member States are encumbered with the application of CFSP measures, while the national courts cannot rule on the validity of Union measures. The general principle of effective judicial protection embodied in Article 47 of the Charter was also invoked, in that it precluded the strict interpretation of the jurisdiction of the CJEU under Article 275. This is followed by the clear position that the CJEU is the only competent court to rule on the validity of the CFSP measure and that national courts have no jurisdiction over such a matter. ${ }^{42}$

The above argumentation as developed by the CJEU has been characterised as integrationist ${ }^{43}$ as it puts forward the idea that within the EU there must be a cohesive system of judicial remedies. There are arguments that the above decision undermines the role of national courts. Koutrakos argues that the implementation of CFSP measures is so dependent on Member State action that will not fall in any case within the jurisdiction of the CJEU. This argument is based on the Opinion of Advocate General's Kokott in Opinion 2/13, ${ }^{44}$ that there is no express provision that CFSP measures can only be reviewed by the CJEU. Furthermore, as per Advocate General Wahl in $H,{ }^{45}$ a national court could suspend the applicability of the measure in question and award damages.

\footnotetext{
${ }^{40}$ S. Poli, 'The Common Foreign Security policy after Rosneft: still imperfect but gradually subject to the rule of law' (2017) 54(6) CMLRev 1799-1834, C. Beaucillon 'Opening up the horizon: the ECJ's new take on country sanctions' (2018) 55(2) CMLRev 387-415.

${ }^{41}$ P. Koutrakos, 'Judicial review in the EU's common foreign and security policy' (2018) 67(1) ICLQ 1-35.

${ }^{42}$ cf. Rosneft (n.39) para 78.

${ }^{43} \mathrm{cf}$. Koutrakos (n.41)

${ }^{44}$ Opinion 2/13 ECLI:EU:C:2014:2475, para 100.

${ }^{45}$ Opinion in Case C-455/14 H P ECLI:EU:C:2016:212, para 103.
} 
There is however a drawback - that while national authorities may be held liable or responsible, the individual applicant will not have obtained redress directly from the EU institutions. It is of importance that the relevant EU institutions face the responsibilities of acts that may not be compatible with human rights and remedy the victims of any violations. The provision of remedies for individuals and the pressure that this may put upon the institutions that form the policy from which the violations have occurred is important so as to ensure that EU policy becomes consistent with the human rights the EU declares to respect. As Advocate General Whal states in his opinion in $\mathrm{H}^{46}$ where the national courts suspends the applicability of the measure, it would then be for the EU institution responsible for the act to draw the necessary inferences from the decision of the national court; by repealing or amending the act whose application vis-a-vis the applicant has been suspended given that the decision of the national court on the lawfulness of an EU act does not, conversely, have effects erga omnes. This may also lead to the disapplication of CFSP measures in different legal orders under different procedures, thus creating a risk in the uniform judicial protection. ${ }^{47}$

Because of the above, the preliminary reference procedure may be a useful alternative to judicial review where the standing requirements become an obstacle. The recent developments in the CJEU's case law have been characterised as level the Article 267 and 263 procedures by breaking the isolation of the CFSP and gradually bringing it into the light of CJEU control. ${ }^{48}$

However, the reality is that the preliminary reference procedure is not a panacea for the flaws of other procedures, and it must not be perceived as such. The inherently indirect nature of Article 267 makes the accessibility to the remedy of invalidation dependent on the Courts which must assess whether there is a matter of EU law at stake, while the fact that only the supreme jurisdiction is obliged to make a reference means that a considerable amount of time may pass before the violation is identified and remedies by the CJEU through the invalidation, which may cause further violations. Therefore, the preliminary ruling procedure as per Article 267 is not in itself an effective remedy for individual applicants.

\footnotetext{
46 Ibid.

47 cf. Koutrakos (n.41) 33

${ }^{48} \mathrm{G}$. Butler, 'The coming of age of the court's jurisdiction in the common foreign and security policy' (2017) 13(4) ECLR 673-703, 701.
} 


\title{
C. The Plea of Illegality: another alternative for fundamental rights protection to Article 263 TFEU?
}

According to Article 277 TFEU, when a case involves an act of general application of a body, institution, office or agency of the Union, a party to that case may raise an issue of legality of that act on the basis of one of the illegality grounds found in Article 263 TFEU. This procedure, according to the Court itself, is used where the applicant would otherwise have no locus standi under the mainstream judicial review procedure. According to the Court in Simmenthal: ${ }^{49}$

\begin{abstract}
"This wide interpretation of [Article 277] derives from the need to provide those persons who are precluded by the second paragraph of Article 173 from instituting proceedings directly in respect of general acts with the benefit of judicial review of them at the time when they are affected by implementing decisions which are of direct and individual concern to them"
\end{abstract}

This provision is important although it is not an autonomous cause of action. ${ }^{50}$ It is indeed important that this provision has led at least to questions of illegality of measures in relation to fundamental rights to be assessed by the Courts. In Health Food Manufacturers, ${ }^{51}$ the applicants claimed that Regulation 1924/2006 regarding health foods infringed their right to be heard, which the General Court dismissed as there had been previous consultation.

In Inuit, ${ }^{52}$ the supplementary plea of illegality went through both the General Court and the CJEU, in addition to the action for annulment, but the CJEU's viewpoint was again that Article 19 of the UN Declaration on Indigenous Peoples was not binding on the Union and that the applicants failed to prove infringement of specific and concrete fundamental rights protected in the Union's legal order. This demonstrates Article 277 does not necessarily mean that the circumvention of the standing criteria will result in a successful claim of illegality ${ }^{53}$ and it

\footnotetext{
${ }^{49}$ Case 92/78 Simmenthal SpA v. Commission [1979] ECR 777, paragraph 41.

50 Case 33/80 Albini v. Council [1981] ECR 2141; Case T-154/94 Comité de Salines de France v. Commission [1996] ECR II-1377.

51 Case T-296/12. The Health Food Manufacturers' Association and Others $v$ European Commission ECLI:EU:T:2015:375

${ }^{52}$ C-398/13 P Inuit Tapiriit Kanatami v European Commission EU:C:2015:535.

53 A. Kornezov, 'Locus standi of private parties in actions for annulment: has the gap been closed?' (2014) 73(1) CLJ 23-28, 26.
} 
certainty does not guarantee effective judicial protection. ${ }^{54}$ This accentuates the role of the Courts' discretion in developing a true and inclusive fundamental rights jurisprudence.

\section{Existent alternatives to the ECHR remedies beyond the EU's legal system}

Another alternative to judicial review is the institution of mechanisms that deal with human rights related complaints within the context of particular agencies or activities. An example is the EULEX the establishment of the Human Rights Review Panel of EULEX, the EU's mission in Kosovo, which examines complaints regarding human rights against the mission. ${ }^{55}$ The role of EULEX in Kosovo is to assist Kosovo's judicial authorities and law enforcement agencies ${ }^{56}$ in light of the fact that Kosovo is still a newly established state in an area of Europe that has been reforming. The objective is to ensure that Kosovo's institutions are impartial and free from political interference. The mission has its mandate until June 2020 with the possibility of renewal. $^{57}$

This panel has been very active and issued several decisions. Each year it issues an Annual Report. Until 2015, the Panel made a finding of a violation in fifteen out of the 152 cases brought before it, ${ }^{58}$ and by 2019 the number of cases has increased considerably. ${ }^{59}$ In light of the absence of general jurisdiction of the EU courts over CFSP/CSDP acts and the problems of extraterritoriality, the establishment of the Human Rights Panel is indeed an effective alternative to the judicial review procedure in terms of ensuring accountability for EU acts that may affect human rights. It must function as an example for the establishment of more such mechanisms for the purposes of ensuring the protection of human rights vis-à-vis EU action that may fall outside the jurisdiction of the CJEU for the review of legality (see more detailed discussion in Part III, Chapter 14).

\footnotetext{
${ }^{54}$ Ibid.

${ }^{55}$ Human Rights Review Panel <http://www.hrrp.eu/relevant-rights.php>

${ }^{56}$ Article 2, Council Joint Action 2008/124/CFSP of 4 February 2008, on the European Union Rule of Law Mission in Kosovo, EULEX Kosovo, as amended by Council Decision (CFSP) 2018/856 of 8 June 2018 amending Joint Action 2008/124/CFSP on the European Union Rule of Law Mission in Kosovo.

${ }^{57}$ EULEX Kosovo <http://www.eulex-kosovo.eu/?page=2,16>

58 Human Rights Review Panel for EULEX, Annual Report for 2015 $\langle$ http://hrrp.eu/docs/HRRP\%20Annual\%20Report\%202015.pdf $>$

59 Human Rights Review Panel for EULEX, Annual Report for 2019 <https://hrrp.eu/docs/HRRP\%20Annual\%20Report\%202019.pdf>
} 
Another example of an alternative is the Complaints Mechanism ${ }^{60}$ and the Fundamental Rights Officer of Frontex. ${ }^{61}$ The Fundamental Rights Officer monitors human and fundamental rights matters that may arise within the context of Frontex activity. The complaints mechanism, which is monitored by the Fundamental Rights Officer, allows complaints for fundamental rights violations occurring during Frontex activity. If such violations are related to Frontex officers, disciplinary measures are taken, ${ }^{62}$ whereas when it relates to the acts of a Member State guard that is followed up with national authorities. ${ }^{63}$ These procedures however, as envisaged by the relevant Regulation, do not expressly provide for a substantive remedy of the violation.

Nevertheless, these procedures may pave the way for establishing a system of accountability for EU acts and violations of human rights caused by such acts, in the absence of a clear scope of application of Article 263 TFEU and the difficulties posed by the action for annulment. They should be further developed and form the example for other areas of EU action.

\section{E. Conclusion}

By consequence of the findings in Chapters 1 and 2 in relation to the remedies deficit, one must turn to other alternatives for challenging the legality of a Union action vis-à-vis human rights.

The preliminary reference procedure and the plea of illegality may be ways to bypass the problems posed by the stringent standing prerequisites. The preliminary reference procedure allows for a national court to require a ruling by the CJEU on the validity of a Union act. However, the preliminary reference procedure is not an action brought directly by a person but is instead dependent on the decision of the national court. The plea of illegality is not an autonomous cause of action and therefore applicants are precluded from using it unless they are involved in another dispute before the CJEU, which is not always the case.

As an alternative for the lack of jurisdiction of the CJEU over CFSP actions as well as the gap left behind by non-accession one can consider specialised bodies such as the EULEX Human Rights Panel in Kosovo and the Fundamental Rights Officer in FRONTEX. While these

\footnotetext{
${ }^{60}$ Regulation (EU) 2016/794, Article 72.

${ }^{61}$ Regulation (EU) 2016/794, Article 71.

${ }^{62}$ Regulation (EU) 2016/794, Article 72(6).

${ }^{63}$ Regulation (EU) 2016/794, Article 72(7).
} 
mechanisms are very significant, they are not courts. Furthermore, they offer piecemeal protection in very specific cases and cannot possibly make up for the shortcomings identified above.

In conclusion, the problems identified in the provision of remedies because of the lack of accession to the ECHR and the problems associated with the judicial review procedure urge us to examine other possible solutions for individuals to have genuine access to substantive remedies for the violations of their human rights by the EU.

Possible solutions to these problems are the use of the damages procedure envisaged in Article 340 TFEU (Part II of the Thesis) and the engagement of the EU's responsibility within the sphere of public international law (Part III of the Thesis). 


\section{Part II}

\section{Non-contractual Liability of the European Union and the Protection of Human Rights}

The central question of this Part is to explore the relationship between the principle of noncontractual liability of the Union and the protection of human rights. The objective of this Part of the thesis is to examine the conditions under which the principle of non-contractual liability may serve the protection of human rights vis-à-vis Union action and provide a substantive remedy for human rights violations committed by the EU.

National legal systems ${ }^{1}$ provide for a procedure through which public authorities may be held liable for and compensate damage they cause through their decisions. The significance of such a procedure is that it takes a different path than the judicial control over public authorities' decisions found in administrative law but rather it allows an injured party to claim redress in order to vindicate her rights. Within the EU's legal system, this protection is afforded by the principle of non-contractual liability of the EU laid down in Article 340 TFEU.

The premise in this Part of the thesis is that non-contractual liability is an important aspect of EU human rights law as it allows the victim of a violation of a human right by a Union act to claim a remedy which will relieve her. The EU's actions are now extending far beyond their

\footnotetext{
${ }^{1}$ In France, according to the rule in the Blanco case (TC 8 February 1873), public authority liability is brought under administrative law and in administrative Courts. While there is no legislative provision, the Conseil Constitutionnel has constitutionalised the principle found in Article 1382 of the Civil Code that a claimant must be given a fair opportunity to bring their claim (Cons Const 13 December 1985, Rec. cons. Const 780) while the Conseil d'État has interpreted as general principles of law the right to be compensated for moral damages (CE 24 November 1961) Letisserand, Rec. CE 1961, 661 GAJA), or to bring a claim for the deceased (CE 29 March 2000 (Assistance publique, Hôpitaux de Paris) D. 2000, 563.) In Germany $§ 839$ of the Bürgerliches Gesetzbuch provides that a civil servant is personally liable for the damage they cause breaching their official duty, while Article 34 of the Basic Law shifts the liability to the state where the public official has exercised state power. In English law, public authorities may be held to be liable via the common law duty of care, if the decision is deemed justiciable - this determined by whether the decision was of an operational or policy nature, with policy decisions being less justiciable, as in X (Minors) v. Bedfordshire County Council [1995] 2 AC 633. For a detailed analysis of these systems see C. van Dam, European Tort Law (2 $2^{\text {nd }}$ edition, OUP, 2013) 531-559. International law also establishes responsibility for international organisations for damage their officials cause as per Difference Relating to Immunity from Legal Process of a Special Rapporteur of the Commission on Human Rights ICJ Reports 1999, pp. 88-89, para. 66 and Article 31 of the Articles on the Responsibility of International Organisations (for further analysis of the relationship between this rule and the Union's responsibility for human rights violations, see Chapter 3 of this thesis) and also for states in Article 31 of the Articles on the Reponsibility of States for Internationally Wrongful Acts.
} 
original reach. Its bodies and agencies act, inter alia in law enforcement, ${ }^{2}$ data collection, ${ }^{3}$ and defence, ${ }^{4}$ which may give rise to human rights questions involving individual rights and freedoms such as private life, fair trial, liberty and security and even the right to life. Violations of rights may entail moral, corporal, material or financial harm. It is therefore imperative that victims of violations have the opportunity to claim effective redress in order to make good the damage caused to them.

The purpose of non-contractual liability is not simply to challenge the lawfulness of the relevant act, but also to remedy the damage caused. A claim for non-contractual liability differs from a procedure for judicial review in this respect. It is not part of an administrative law procedure of annulling an act passed by the relevant institution but its aim is to compensate the damage that has been suffered by an applicant, in the same way that domestic civil or tort law establishes civil liability of public bodies. Early in the EU case law, this was already held in Schöppenstedt ${ }^{5}$ where the Court specifically highlighted the 'autonomous nature' of Article 340 vis-à-vis Article 263 on judicial review. Therefore, Article 340 is not dependent of an action for annulment and may be brought separately of such an action. The criteria for standing applying in Article 263 play no role in the procedure for non-contractual liability. ${ }^{6}$

The procedure of non-contractual liability is modelled after civil liability rules, which require unlawful conduct, damage and a causal link between the unlawful conduct and the damage. Non-

\footnotetext{
${ }^{2}$ Regulation (EU) 2016/794 of the European Parliament and of the Council of 11 May 2016 on the European Union Agency for Law Enforcement Cooperation (Europol) and replacing and repealing Council Decisions 2009/371/JHA, 2009/934/JHA, 2009/935/JHA, 2009/936/JHA and 2009/968/JHA, Article 49 of this Regulation makes EUROPOL accountable before the EU's judiciary in relation to any damage caused during its activities.

${ }^{3}$ Data Collection is one of the key methods used by the European Anti-Fraud Office (OLAF), as part of the fight against fraud provided by Article 325 TFEU. This was established by as amended by Commission Decision of 27 September 2013 amending Decision 1999/352/EC, ECSC, Euratom establishing the European Anti-fraud Office and Commission Decision (EU) 2015/512 of 25 March 2015 amending Decision 1999/352/EC, ECSC, Euratom establishing the European Anti-fraud Office, of which the powers for investigation are laid down in Regulation (EU, Euratom) No 883/2013 of the European Parliament and of the Council of 11 September 2013 concerning investigations conducted by the European Anti-Fraud Office (OLAF) and repealing Regulation (EC) No 1073/1999 of the European Parliament and of the Council and Council Regulation (Euratom) No 1074/1999.

${ }^{4}$ Articles 42 and 43 TEU.

${ }^{5}$ Case 5/71 Aktien-Zuckerfabrik Schöppenstedt v. Council [1971] ECR 975.

${ }^{6}$ Case C-390/95 P Antillean Rice Mills NV v. Commission [1999] ECR I-769, where the CJEU noted in paragraph 62 '[I]t must be stated that the fact they are individually concerned has no effect on the character of the measure in the context of an action for damages since that action is an independent remedy...'
} 
contractual liability is also distinguished from the Union's contractual liability as it does not require a contractual relationship with the applicant. ${ }^{7}$

Contractual liability in any case falls under the jurisdiction of national courts, according to Article 274 TFEU, unless an arbitration clause is included in the relevant contract which confers jurisdiction to the Union's judicature based on Article 272 TFEU. Another distinctive feature of the action for damages is that the Union's Courts have jurisdiction without any need for the parties in the dispute to express their consent thereto. ${ }^{8}$

The link between the existence of the action for damages and human rights is crucial for the discussion that will follow. Above all, the existence of this procedure comes in to fulfil one of the most important fundamental rights guarantees, which is the right of every person to have an effective remedy before a tribunal - an obligation which is imposed onto the EU's institutions and judicature in Article 47 of the EU Charter of Fundamental Rights. Therefore, where an individual believes that her fundamental rights were not respected by Union action is entitled to seek an effective remedy by having access to the EU's courts - and this entitlement is at least in principle, protected through the action for damages.

Chapter 4 will introduce and explain as a preliminary point the relationship between noncontractual liability and human rights issues. Then the criteria for the establishment of noncontractual liability will be examined vis-à-vis human rights cases. Those criteria are unlawfulness (Chapter 5) damage and causation (Chapter 6). The subject matter of Chapter 7 will be the relationship between the doctrine of non-contractual liability for lawful acts of the Union and human rights. Finally, Chapter 8 will assess the material scope of application of the principle of non-contractual liability and how this relates to the remedy's effectiveness for human rights violations.

\footnotetext{
${ }^{7}$ Case C-103/11 P Commission v. Systran and Systran Luxembourg (judgment of 18 April 2013, not yet reported) §76. Case T-367 Technoprocess v. Commission [2011] ECR II-209.

${ }^{8}$ K. Lenaerts, I. Maselis, K. Gutman and J.T. Nowak, (ed) EU Procedural Law (OUP 2014) 484.
} 


\section{Chapter 4}

\section{Introducing the relationship between non-contractual liability and human rights claims}

\section{A. Introduction}

The objective of this Chapter is to demonstrate, as the basis of this Part, the relationship of the principle of non-contractual liability in EU law with rights-based claims. It will introduce the basic legal provisions laying down the principle of non-contractual liability in Section (B). Section (C) will be an introduction to the essential criteria and elements required for a claim of non-contractual liability to be successful, as they have been formulated by the case law. Section (D) will discuss the importance of the existence of interim relief within the framework of noncontractual liability for the protection of human rights. Section (E) will give certain examples where non-contractual liability has been invoked in rights-based claims in order to demonstrate the use of the principle for the protection of rights within the Union.

\section{B. The legal provisions and theoretical underpinning of non-contractual liability}

The key provision for the non-contractual liability of EU institutions under EU law is Article 340(2) TFEU, which provides:

"In the case of non-contractual liability, the Union shall, in accordance with the general principles common to the laws of the Member States, make good any damage caused by its institutions or by its servants in the performance of their duties."

This is complemented by Article 268 TFEU, which grants exclusive jurisdiction to the Union's judiciary for damages claims. In essence, the procedure envisaged is a form of 'public authority liability' ${ }^{1}$ so that the Union's authorities must compensate for any damage, be it material, financial or moral, they may have caused through their action or omission.

As it will be examined in more detail below Chapter 5, Section (B), non-contractual liability requires as a starting point, the infringement of a legal rule conferring rights to individuals. With

\footnotetext{
${ }^{1}$ C. van Dam, European Tort Law (OUP 2013) 559-568, where non-contractual liability of the Union is analysed in the Chapter in relation to 'Liability of Public Bodies'.
} 
fundamental rights being part of primary EU law through their inclusion in the EU Charter of Fundamental Rights and their incorporation in several provisions of the Treaties, ${ }^{2}$ they may be invoked as the legal rule which has been violated. The meaning of a superior rule of law includes the Treaties, fundamental rights, ${ }^{3}$ the general principles of EU law ${ }^{4}$ or even superior secondary legislation. ${ }^{5}$

A particular feature of such rights-conferring legal provisions is that they often include the definition of the scope of the right protected. This means that where the Courts examine the unlawfulness of Union action vis-à-vis a legally recognised right, the Courts have to examine the Union's action against that prescribed scope of the right in question. For example, Article 15 of the Charter which guarantees the freedom to choose an occupation, limits the scope of the freedom to seek employment, work or establishment in any Member State to Union citizens, while it gives third-country nationals the right to have equal working conditions as Union citizens. As such, the Court will assess to what extent the relevant Union act has violated the EU citizen's freedom to seek employment, work or establishment in any other Member State, and in the case of a third country national, the right to have equal working conditions - that determines the unlawfulness of the measure.

Rights conferring rules may include the scope of enjoyment of the right as well as outline the situations where this right may be limited, without being considered as violated. An example, that for the purposes of demonstrating how rights-conferring rules define the scope of the right contained therein, is Article 17 of the Charter:

\footnotetext{
${ }^{2}$ Examples include but are not limited to Article 2 TEU enumerating human dignity and respect for human rights as a founding value of the Union, Article 6 TEU which gives binding force to the EU Charter of Fundamental Rights and recognizes Fundamental Rights as a principle of Union law, Article 8 TFEU obliges the Union to promote equality, Article 16 TFEU recognises the protection of personal data, Article 17 TFEU that states that the Union respects philosophical and religious groups.

${ }^{3}$ Joined Cases C 120/06 and C121/06 FIAMM and Others v. Council and Commission [2008] ECR I-06513.

${ }^{4}$ Case T-16/04 Arcelor SA v. European Parliament and Council, 2 Mar 2010.

${ }^{5}$ For example, certain legislative acts within the Union's legal order may be passed by virtue of other, hierarchically superior legislative acts - this is a common method in the Common Agricultural Policy. See Case 74/74 Comptoir National Technique Agricole (CNTA) SA v. Commission [1975] ECR 533, and P. Craig and G. de Búrca, EU Law Texts, Cases and Materials (6 ${ }^{\text {th }}$ edition, OUP 2015) 586.
} 


\section{Figure 1:}

Article 17 Right to property

1. Everyone has the right to own, use, dispose of and bequeath his or her lawfully acquired possessions. No one may be deprived of his or her possessions, except in the public interest and in the cases and under the conditions provided for by law, subject to fair compensation being paid in good time for their loss. The use of property may be regulated by law in so far as is necessary for the general interest.

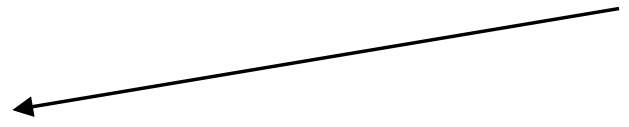

$\underline{\text { Scope of Enjoyment }}$

1. Own property

2. Use property

3. Dispose property

4. Bequeath property

5. Intellectual property is also protected

\section{Condition for Enjoyment}

Property must be

lawfully acquired

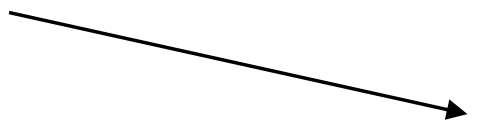

$\underline{\text { Possible Limitations }}$

1. Deprivation of property

2. Regulation of use of property

Conditions for Limitations
1. Deprivation:
a. existence of a public interest
b. deprivation is conducted under conditions
provided for by law
c. there must be fair compensation paid in good
time for the loss of property
2. Regulation of use:
a. the regulation must be by law
b. it must be necessary for the general interest


The Court must examine whether there has been a limitation of the right to use, own, dispose or bequeath the property, given that it is lawfully acquired. If that limitation is deprivation, it must be done for the public interest, under conditions provided by law and the authority depriving the person of her property must provide compensation. If it is regulation of the use, it must be according to law as well as necessary for the general interest. Therefore, when a fundamental right violation is the alleged 'infringement of a legal rule' then the infringement must be understood in the context of the scope provided for by the relevant EU law provisions that confer the right to the individual.

Consequently, the basis of non-contractual liability in EU law is the existence of a rule which confers rights to individuals, as conceived initially in German law, which inevitably includes human rights norms. This is of utmost importance; the fact that non-contractual liability is engaged by the breach of a rights-conferring rule constitutes Article 340 a tool for the protection of human and fundamental rights. Above all, it provides the CJEU with the possibility of developing jurisprudence in relation to the obligations of the Union vis-à-vis human rights rules as well as the scope and interpretation of human rights rules applicable on the EU.

\section{Introducing the criteria of Article 340 TFEU}

The pre-requisites for claiming damages against EU institutions are the triptych of unlawful action - damage - causation. The Court of Justice in one of its earliest authoritative cases on the issue, Schöppenstedt ${ }^{6}$ stated that:

'11... the non-contractual liability of the Community presupposes at the very least the unlawful nature of the act alleged to be the cause of damage...'

Therefore, according to Schöppenstedt, ${ }^{7}$ the act which is being challenged must be the cause of the damage claimed, and it must also be established to be unlawful (Chapter 6 below). In a more elaborate description, the Court held in FIAMM: ${ }^{8}$

\footnotetext{
${ }^{6}$ Case 5/71 Aktien-Zuckerfabrik Schöppenstedt v. Council [1971] ECR 975

7 Ibid.

${ }^{8}$ Joined Cases C 120/06 and C121/06 FIAMM and Others v. Council and Commission [2008] ECR I-06513.
} 
"The Court has consistently interpreted the second paragraph of Article [340] as meaning that the non-contractual liability of the Community and the exercise of the right to compensation for damage suffered depend on the satisfaction of a number of conditions, relating to the unlawfulness of the conduct of which the institutions are accused, the fact of damage and the existence of a causal link between that conduct and the damage complained of (see, inter alia, Case 26/81 Oleifici Mediterranei v EEC [1982] ECR 3057, paragraph 16, and Case C-146/91 KYDEP v Council and Commission [1994] ECR I-4199, paragraph 19).”

This definition enumerates the three requirements for success in a non-contractual liability procedure: the unlawfulness of the challenged action, a damage that has been suffered by the applicant and a causal link between the unlawfulness and the damage. These three conditions must exist cumulatively and if one of these is absent, the claim will fail. ${ }^{9}$

Once the unlawfulness of the act is established, the applicant ought to prove that she suffered damage which is certain, ${ }^{10}$ specific, ${ }^{11}$ proven $^{12}$ and quantifiable, ${ }^{13}$ and that there was a causal link between the unlawful act and the damage sustained. ${ }^{14}$ The concepts of damage and causation within the damages action and their relation to human rights will be analysed in further detail in Chapter 6 below.

In terms of procedural law, it must be borne in mind that Article 46 of the Statute of the Court of Justice provides that there is a five-year limitation period for such actions. The Court has interpreted this as meaning five years from the point where the three requirements establishing non-contractual liability have materialised, and when it comes to legislative measures from the point when the injurious effects have been produced. ${ }^{15}$

\footnotetext{
${ }^{9}$ Case T-291/04 Enviro Tech Europe Ltd and others v European Commission [2012] 2 CMLR 2, para. 123.

${ }^{10}$ Cases 56-60/74 Kampffmeyer v. Commission and Council [1976] ECR 711,

${ }^{11}$ Ibid.

12 Case Fux v. Commission [1969] ECR 145.

${ }^{13}$ See AG's Capotorti Opinion in Case 238/78 Ireks-Arkady v. Council and Commission [1979] ECR 2955.

${ }_{14}$ Cases 64, 113/76, 167, 27, 28, and 45/79 Dumortier Freres SA v. Council [1979] ECR 3091.

${ }^{15}$ Case T-138/03 É. R. and Others $v$ Council of the European Union and Commission of the European Communities [2006] ECR II-04923. Case C-282/05 P, Holcim, 2007] ECR I-2941 para 29. For detailed discussion, see T. Heukels and A. McDonnell, 'Limitation of the action for damages against the Community: Considerations and new developments', in T. Heukels and A. McDonnell, The Action for Damages in Community Law (Kluwer 1997) 217241, M. Broberg, 'The calculation of the period of limitation in claims against the EuropeanCommunity for noncontractual liability', (2001) 26 ELR 275-290.
} 


\section{Significance of interim relief for the protection of rights within the action for damages procedure}

An applicant claiming damages caused by Union action is undoubtedly interested in protecting their rights throughout the procedure. For such protection, interim measures are provided for by EU law, although applicants are rarely successful in obtaining them. ${ }^{16}$ Article 278 TFEU provides that in the case of a contested act the Court may suspend it, should it judge that the circumstances so require. Article 279 TFEU also provides that the CJEU may prescribe any other necessary interim measures.

Article 160(3) of the CJEU's Rules of Procedure and Article 104(2) of the GCEU's Rules of Procedure state that in an application for interim measures, the applicant must prove that they have a prima facie case and that there is an urgency due to a risk of irreparable damage which justifies the interim relief applied for, in order to prevent irreparable damage to the applicant's interests. ${ }^{17}$ Another factor, according to the case law, is the balancing of interests between the interests of the applicant and the EU institution party or even public interest. ${ }^{18}$

Where the interim measures application requests the suspension of the act, that act must be 'enforceable'. ${ }^{19}$ Therefore acts of a 'negative nature' such as an omission cannot be suspended, as they are not enforceable, unless there is a change in the applicant's legal position. ${ }^{20}$ Interim relief is an important tool at the disposal of the Court in cases where human rights are concerned, as it may prevent further violations and deprive the applicant of a future opportunity to claim her rights.

Individual applicants who claim their rights have been violated have sought to suspend measures

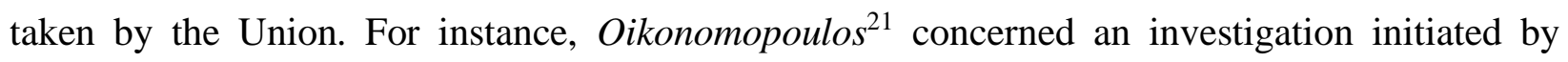
OLAF (European Anti - Fraud Office) where the applicant was named as a person against whom

\footnotetext{
${ }^{16}$ M. Clough, 'Potential legal challenges to EU sanctions' ITLR 27-37, 33.

${ }^{17}$ K. Lenaerts, I. Maselis, K. Gutman and J.T. Nowak, (ed) EU Procedural Law (OUP 2014) 570.

${ }^{18}$ Case C-445/00 R Austria v Council [2001] ECR I-1461, paragraph 73, Case C-644/11 P(R) Qualitest v. Council (Order of the President of 14 June 2012), not yet reported, where the applicant's interests did not outweigh the public interest of protection from terrorism.

${ }^{19}$ Case T-19/91 R Vichy v. Commission [1991] ECR II-265.

${ }^{20}$ Case 76/88 R La Terza v. Court of Justice [1988] ECR 1741.

${ }^{21}$ Case T-483/13 R. Oikonomopoulos v Commission, Order of the President of the General Court of 27 November 2013.
} 
the Union had grounds for believing that he was engaged in criminal conduct against the interests of the Union. The applicant brought a claim against the OLAF for damages on the basis that his private life and reputation were violated and also asked for a suspension of the measures taken by the OLAF and their further transmission to national authorities, by way of an injunction. The Court rejected the granting of such measures as the damage claimed could not be regarded as irreparable.

The General Court of the EU in Trabelsi stated that within the context of Article 340(2), granting interim measures is exceptional. ${ }^{22}$ One of the reasons of difficulty is that there must be concordance between the subject matter of the action and the measures sought - and as the subject matter of the damages action is not the annulment of the act, claiming the act's suspension through an application for interim measures may be difficult to succeed. ${ }^{23}$ As the aim of an action for annulment is to cease the effects of the contested act, suspending and thus by freezing the effects of the contested act will preserve the status quo so as to guarantee the effectiveness of a judgment annulling the act. The action for damages does not aim to annul and withdraw the relevant act but rather the granting of compensation - this means that the objective of interim relief is to prevent further damage from occurring.

It has been held that the right to effective judicial protection of individuals before the EU courts precludes an absolute prohibition of interim measures in damages' cases - such interim measures may include even the provisional payment of the compensation sought. In Antonissen, ${ }^{24}$ the President of the Court stated the following:

"An absolute prohibition, irrespective of the circumstances of the case, on obtaining in the context of an interim application a measure granting (by way of advance) a part of the compensation claimed, on the basis of Article 178 and the second paragraph of Article 215 of the Treaty, in the main proceedings, and with a view to protecting the applicant's interests until judgment is delivered in those proceedings, would not be compatible with the right of individuals to complete and effective judicial protection under Community law, which implies in particular that interim protection be available to them if it is

\footnotetext{
${ }^{22}$ Case T-187/11 R Trabelsi and Others v. Council [2011] ECR II-235, §50.

23 cf. Lenaerts et al (n.17) 570.

${ }^{24}$ Case C-393/96 P (R) Antonissen v. Council and Commission [1997] ECR I-441, §6.
} 
necessary for the full effectiveness of the definitive future decision. It is therefore not possible to rule out in advance, in a general and abstract manner, that payment, by way of an advance, even of an amount corresponding to that sought in the main application, may be necessary in order to ensure the practical effect of the judgment in the main action and may, in certain cases, appear justified with regard to the interests involved."

Therefore, as the deliberations of the Court demonstrate, provisional measures protect the right to effective judicial protection, also within the action for damages procedure. Through guaranteeing the right to effective judicial protection, the further violation of the rights claimed to have been violated may also be prevented. However, the stringent criteria applied by the Courts in granting interim relief within the context of Article 340(2) and the Court's position that such granting is exceptional, undermine the true effectiveness that interim relief may have in terms of protecting human rights.

\section{E. Applicability of non-contractual liability to human rights violations}

The procedure of claiming damages against the EU functions as a legal remedy within the EU's judicial system, when an individual has her rights infringed by the Union. It has already been discussed in detail above, that the theoretical foundation of non-contractual liability the violation of a rule which protects one or more persons. An example of a successful claim which involved such human rights considerations is the case of Nikolaou v. Commission. ${ }^{25}$ In this dispute, the applicant was a Member of the Court of Auditors, whose actions while in office were being investigated by the European Anti-Fraud Office (OLAF). The OLAF had published a press release and an Annual Report with information regarding the inquiry and also let out information which included personal data.

The applicant brought an action for non-contractual liability claiming, among other things, a violation of the protection of personal data, ${ }^{26}$ and also that her private and family life had been disturbed by the leaking of information. The applicant sought compensation for the damage she had suffered, which included damages to the applicant's health and 'moral damage'. The Court of First Instance partially allowed the claim and granted the applicant the amount of $€ 3,000$. It

${ }^{25}$ Case T-259/03 Kalliopi Nikolaou v. Commission [2007] ECR II-00099.

${ }^{26}$ Today this is protected under Article 8 of the Charter, which at the time was not yet binding. 
must be borne in mind that at the time of this judgment, the Charter was not binding on EU institutions, but the latter still had an obligation to respect fundamental rights as part of the general principles that underpin EU law.

Nevertheless, this case serves to understand the importance and use of this procedure for the protection of human rights and the remedying of their violation. A body of the European Union, the OLAF, had taken action against a natural person, during which it committed acts that violated her privacy. Privacy is a fundamental right which is also part of the general principles of EU law thus obliging the Union to respect the privacy of persons (detailed analysis of the general principles of EU law may be found in Part I of this Thesis). According to the applicant, she suffered both physical and moral damage and as the CFI agreed with the applicant, it accordingly ordered her compensation.

As the EU's institutional structure is constantly expanding, human rights are far more likely to be violated by institutions and authorities that take action or impose measures that have a restrictive or detrimental effect on individuals. Therefore, the procedure for engaging the Union's noncontractual liability is a valuable tool for the individual who believes that the Union has acted contrary to her rights.

The binding nature of the Charter on the institutions of the Union is even more important today the infringement of a Charter right has been expressly recognised by the CJEU as a ground for claiming damages for non-contractual liability. ${ }^{27}$ Article 51(1) of the Charter specifically states that the provisions of the Charter are addressed to the institutions, bodies, offices and agencies of the Union and that these shall respect the rights and principles of the Charter. The imperative character of this provision makes it clear that where the EU's institutions, bodies, offices and agencies of the Union do not respect the Charter's provisions they violate their legal obligations and therefore that the Charter provisions are rules of law establishing duties for the institutions and rights for the individuals.

It is evident, by virtue of this provision, that an applicant may base their non-contractual liability claim on rights contained in the Charter. This possibility was highlighted by the CJEU in Groupe

${ }^{27}$ Case C-58/12 P Groupe Gascogne SA v European Commission [2014] 4 CMLR 14 and Case C-40/12 Gascogne Sack Deutschland GmbH v European Commission [2014] 4 CMLR 12. 
Gascogne SA v European Commission ${ }^{28}$ and the GCEU in Gascogne Sack Deutschland GmbH v European Commission, ${ }^{29}$ where identical words were used, in relation to an alleged violation of a Charter right by the EU's judiciary:

"It is therefore appropriate for the Court of Justice to rule that the sanction for a breach, by a Court of the European Union, of its obligation under the second paragraph of Article 47 of the Charter to adjudicate on the cases before it within a reasonable time must be an action for damages brought before the General Court, since such an action constitutes an effective remedy."

There are, however limitations. The case law demonstrates an increased difficulty in bringing a successful claim for non-contractual liability due to the complex notions developed over the years by the Court's case law, and the restrictive approach that the Court has followed. ${ }^{30}$

It must be taken into account that not all damages actions based on rights violations are successful; in Ledra Advertising, ${ }^{31}$ for example, the claimants brought an action for damages against the Commission and the European Central Bank for the Memorandum of Understanding adopted in 2013, which imposed a direct cuts from individuals' deposits in Cypriot banks in order to stabilise the country's banking sector. The claimants' position was that this MoU was in violation of Article 17(1) of the Charter, protecting the right to property. The CJEU's decision was that the restrictions of the right were proportional to the aim to be achieved; the latter being the avoidance of a spill-over effect to other banks or even the economies of other Member States. As such, the claim was dismissed as the restriction was deemed lawful.

28 Ibid.

${ }^{29}$ Ibid.

30 A. Albors-Llorens, 'Remedies against EU institutions after Lisbon - an era of opportunity?' (2012) 71(3) CLJ 532-33, J. Wakefield 'Retrench and Reform: The Action for Damages' (2009) 28 YEL 390, 432-434.

31 Joined Cases C-8/15 P to C-10/15 P Ledra Advertising Ltd and Others v European Commission and European Central Bank (ECB) Judgment of the Court (Grand Chamber) of 20 September 2016 ECLI:EU:C:2016:701 this decision can be contrasted to Joined Cases C-105/15 P to C-109/15 P. Konstantinos Mallis and Others $v$ European Commission and European Central Bank (ECB) Judgment of the Court (Grand Chamber) of 20 September 2016 ECLI identifier: ECLI:EU:C:2016:702 which was issued on the same date with the same subject matter, but concerned an annulment procedure under Article 263 TFEU, where the Court decided that the actions of the Commission within the framework of the ESM are not reviewable EU acts. 
While this case is an example of the use of this principle as a path towards claiming one's rights, the position of the CJEU in essence brings forward the idea that the core of the EU's objective is the protection of economic interests.

After this preliminary analysis of the core topic of this Part, it is necessary to understand the significance of this procedure and each of the criteria established by the Court, as regards possible claims that will be relevant for the protection of human rights. 


\section{Chapter 5}

\section{Non -contractual liability: the Concept of Unlawfulness and Human Rights}

\section{A. Introduction}

As per Schöppenstedt, ${ }^{1}$ there needs to be at the very least, a conduct of unlawful nature on behalf of a Union body, official or institution, for a damages action to be successful. Nevertheless, as it will be analysed in this Chapter, the meaning of 'unlawfulness' within the context of an action for damages has been the subject of extensive judicial interpretation. This concept of unlawfulness within damages actions based on rights violations, is also interpreted in its own unique way.

This Chapter will deal with this interpretation of unlawfulness within damages actions and in particular where these actions relate to rights claims. The essence is that where the action concerns a human, or fundamental rights 'unlawfulness' is not determined by the usual standards of unlawfulness developed by the Court's case law, but on the basis of the scope of the right in question.

It has been discussed in Chapter 4 above that the fundament of non-contractual liability is the violation of a rule conferring rights to individuals and by extent duties to the respondent institution. A rights-conferring rule may define the scope of the right and its limitations, and therefore unlawfulness ought to be determined purely on human rights terms.

Section (B) constitutes an introduction to the definition of 'unlawfulness', with particular reference to the similarities and differences between the notion of unlawfulness in damages procedures and annulment procedures and to how the case law has interpreted unlawfulness in cases involving discretionary and non-discretionary acts, as in the latter case a different threshold of 'grave disregard to the institution's discretion' is set. Section (C) will continue to develop on that topic by attempting to position the concept of 'sufficiently serious breach' where the damage action is concerned with a rights-based claim. Section (D) will examine whether, in light of the Courts' interpretation of 'sufficiently serious breach' in rights-based cases, the distinction of the

\footnotetext{
${ }^{1}$ Case 5/71 Aktien-Zuckerfabrik Schöppenstedt v. Council [1971] ECR 975.
} 
nature of the breach used by the Court for discretionary and non-discretionary acts, is a useful and effective distinction. Section (E) will conclude this Chapter with some observations on the case law, and how this has shaped the relationship of the notions relative to unlawfulness and human rights cases.

\section{B. Unlawfulness in Damages Actions and the Protection of Rights}

The first requirement for a successful application under Article 340 TFEU is the finding of unlawfulness that taints the act contested by the applicant (See Chapter 4, Section (C), above). The Court in Schöppenstedt stated that there needs to be a 'sufficiently flagrant violation of a superior rule of law for the protection of the individual ${ }^{2}$ to lead to a finding of unlawfulness.

The meaning of 'flagrant' has developed over the years through the case law of the Union's judiciary. Initially, it was interpreted as requiring a demonstration of serious effects of the relevant breach, such as an exceptional gravity of the damage which was suffered by the applicant. ${ }^{3}$ In Bergaderm ${ }^{4}$ the CJEU reformulated the test to a 'sufficiently serious breach' and stated:

"40. The system of rules which the Court has worked out with regard to [Article 215] takes into account, inter alia, the complexity of the situations to be regulated, difficulties in the application or interpretation of the texts and more particularly, the margin of discretion available to the author of the act in question. (Brasserie du Pêcheur, para. 43)"

The CJEU therefore adopted the approach that was followed in Brasserie du Pêcheur ${ }^{5}$ for Member State liability and laid down certain guidelines for a finding of unlawfulness which concerned with the clarity of the relevant rule, the difficulty or the complexity of the subject matter of the act and also the extent of the discretion enjoyed by the institution. Indeed, Eeckhout characterises the criteria for state liability and non-contractual liability of the Union as "two sides

\footnotetext{
${ }^{2}$ Ibid.

3 See Cases 83,94/76, 4, 15 and 40/77 Bayerische HNL Vermehrungbetriebe GmbH \& Co KG v. Council and Commission [1978] ECR 1209 and Amylum NV and Tunnel Refineries Ltd v. Council and Commission [1979] ECR 3497.

${ }^{4}$ Case C-352/98 P Laboratoires Pharmaceutiques Bergaderm SA and Goupil v. Commission [2000] ECR I - 5291.

${ }^{5}$ Cases C-46 and 48/93, Brasserie du Pêcheur SA v. Germany, $R$ v. Secretary of State for Transport ex $p$ Factortame Ltd [1996] ECR I-1029.
} 
of the same coin," that coin being the protection of the individual. The two procedures are indeed closely linked due to the same case law they are founded on. ${ }^{7}$

It is important to note that the Courts of the EU apply two different tests to satisfy the criterion of the "sufficiently serious breach" depending on whether the commission of the challenged act involved the use of the institution's discretion. Where the case is concerned with an action not involving the use of discretion any infringement of a rule conferring rights on individuals can constitute unlawfulness and be considered a sufficiently serious breach ${ }^{8}$ and the applicant then has to establish that some damage was caused due to this violation. ${ }^{9}$ Where the act concerned has been enacted following the exercise of discretion the Court requires a grave disregard to the limits of that discretion. ${ }^{10}$ In Bergaderm ${ }^{11}$ the Court held that the nature of the act (legislative or non-legislative, general or individual) is not a decisive factor as to whether it is characterised as 'discretionary'. The decisive criterion is whether the provision, on which the challenged measure is based, requires the relevant institution to make a policy choice. ${ }^{12}$

It has been claimed that when an action for annulment and an action for damages are brought in parallel and the applicant has failed to show the existence of unlawful conduct in the context of proceedings for annulment, the claim for damages will also be rejected since the first condition for non-contractual liability will not have been met. ${ }^{13}$ In fact, CJEU in its earlier case law took the view point that an action for damages required first a finding of unlawfulness. In Plaumann ${ }^{14}$ the Court had said that no administrative act could be declared unlawful within the context of an action for damages, if it had not first been annulled.

\footnotetext{
${ }^{6}$ P. Eeckhout, 'Liability of Member States in damages and the Community system of remedies', in J. Beatson and T. Tridimas (eds.), New Directions in European Public Law (Hart, 1998), 63-73, at 64.

${ }^{7}$ K. Gutman, 'The Evolution of the Action for Damages against the European Union and its Position in the System of Effective Judicial Protection' (2011) CMLRev 48, 695-750, 709.

${ }^{8}$ Cases T-79/96, 260/97 and 117/98 Camar Srl and Tico Srl v. Commission [2000] ECR II-2193, para. 205.

${ }^{9}$ Cases 44-51/77 Union Malt v. Commission [1978] ECR 57.

${ }^{10}$ cf. Bergaderm (n.4).

${ }^{11}$ Ibid.

12 K. Lenaerts, I. Maselis, K. Gutman and J.T. Nowak, EU Procedural Law (OUP 2014), and Case T-155/99 Dieckmann \& Hansen v. Commission [2001] ECR II-3143.

${ }^{13}$ S. L. Kaleda, 'Claims for damages in EU procurement and effective protection of individual rights' (2014) 39(2) ELR 193-209, 205.

${ }^{14}$ Case 25/62 Plaumann v. Commission [1963] ECR 95, §108.
} 
While this is not the judicial understanding of unlawfulness today, if the applicant has established an infringement of a rule of law in the context of the action for annulment, this will suffice in most cases to prove unlawful conduct in the context of the claim for damages. ${ }^{15}$ Therefore, even though the purposes of these two provisions are distinct, they still share a foundation in that there needs to be a finding of unlawfulness. In 2013 the General Court held in Evropaiki Dynamiki ${ }^{16}$

"72 In the present case, in the context of the application for annulment of the contested decision insofar as it concerns Lot 2, it has been held that that decision was not vitiated by unlawfulness.

73 As the condition relating to the unlawfulness of the conduct alleged against the Commission has not been fulfilled, the claim for damages must be rejected as unfounded and, therefore, the application must be dismissed in its entirety."

As Lenaerts points out ${ }^{17}$ unlawfulness in the action for damages procedure differs from the unlawfulness in an action for annulment. This was also the position taken by Mead in the late 1990s, ${ }^{18}$ and in 2011 by Gutmann. ${ }^{19}$ EU case law also takes the stance that the judicial assessment of unlawfulness in the two procedures is different. ${ }^{20}$ The criteria for unlawfulness are indeed different in the two procedures, ${ }^{21}$ given that the grounds of review set out in Article 263(4) include primary law, the general principles, misuse of powers, lack of competence and essential procedural requirements, while Article 340 examines the legality in relation with potentially any legal rule conferring rights on individuals. ${ }^{22}$ The case law has encompassed

\footnotetext{
15 Ibid.

16 Case T-9/10 Evropaïki Dynamiki - Proigmena Systimata Tilepikoinonion Pliroforikis kai Tilematikis AE v European Commission [2013] ECR 0.

${ }^{17}$ K. Lenaerts, I. Maselis, K. Gutman and J.T. Nowak, EU Procedural Law (OUP 2014) 490.

${ }^{18} \mathrm{P}$. Mead, 'The relationship between an action for damages and an action for annulment: The return of Plaumann', in T. Heukels and A. McDonnell, (Eds.), The Action for Damages in Community Law (Kluwer 1997), $243-258$.

19 cf. Gutman K. (n.7) 703.

20 See e.g. Case T-212/03, MyTravel Group plc v. Commission, [2008] ECR II-1967, para85; Case T-429/05, Artegodan GmbH v. Commission, judgment of 3 March 2010, nyr, paras. 50-51.

${ }^{21}$ cf. Lenaerts et al (n.17) 490.

${ }^{22}$ Case T-364/03 Medici Grimm v. Council [2006] ECR II-79 §\$61-62.
} 
provisions of the Treaties, fundamental rights, ${ }^{23}$ the general principles of EU law $^{24}$ and superior secondary legislation, but for example, not the duty to give reasons. ${ }^{25}$

The concept of the superior rule of law conferring rights to individuals derives from the doctrine of the Schutznorm, in German law. Article 34 of the German Basic Law (Grundgesetz) provides that:

"If any person, in the exercise of a public office entrusted to him, violates his official duty to a third party, liability shall rest principally with the state or public body that employs him. In the event of intentional wrongdoing or gross negligence, the right of recourse against the individual officer shall be preserved. The ordinary courts shall not be closed to claims for compensation or indemnity"

In the Advocate General's Opinion in Hedley Lomas ${ }^{26}$ specific reference was made to the Schutznormtheorie and explains that the concept of a superior rule of law protecting the individual is seen as an application of the Schutznorm contained in Article 34 of the German Basic Law. ${ }^{27}$ Article 34 of the German Basic Law specifically provides for a duty to third persons - and the German Bundesgerichtshof has understood this to mean that liability presupposes the existence of the duty towards a person or a group of persons. ${ }^{28}$ The Advocate General proceeded by adding that liability for the breach of a rule protecting an individual right occurs when the individual claiming the right falls within a group that is protected by the relevant superior rule of law. ${ }^{29}$

${ }^{23}$ Joined Cases C 120/06 and C121/06 FIAMM and Others v. Council and Commission [2008] ECR I-06513

${ }^{24}$ Case T-16/04 Arcelor SA v. European Parliament and Council [2010] ECR II-211.

${ }^{25}$ Cases T-64 and 65/01 Afrikanische Frucht-Compagnie GmbH v. Council and Commission [2004] ECR II-521.

${ }^{26}$ Opinion of A.G. Leger in Case C-5/94 Hedley Lomas [1996] ECR I-2553

${ }^{27}$ The Advocate General's Opinion mentions that this viewpoint is taken by academic literature and refers to the authoritative publication W. Van Gerven, 'Non-contractual Liability of Member States, Community Institutions and Individuals for Breaches of Community Law with a View to a Common Law for Europe', Maastricht Journal, 1, 1994, which in turn refers to W. van Gerven, 'De niet-contractuele aansprakelijkbeid van de Gemeenschap wegens normatievehandelingen', S.E.W. (1976), 2, at 21-2, and T. Heukels, 'De nietcontractueleaansprakelijkheid van de Gemeenschap ex art. 215, lid 2 EEG: Dynamiek en continuiteit (1983-1991)', SEW (1992), 151 et seq. and 317 et seq., at 326 , paras 21 and 22 .

${ }^{28}$ See the judgment of 12 March 1987 of the Bundesgerichtshof, Juristen Zeitung, 1987, p. 1024. See also BGHZ 100, p. 136, and BGHZ 102, p. 350.

${ }^{29}$ cf. Opinion of A.G. Leger in Hedley Lomas (n.26), point 133, 516 and see also W. van Gerven, 'Bridging the unbridgeable: Community and national tort laws after Francovich and Brasserie' (1996) 45(3) ICLQ 507-544. 
Before the establishment of damage or causation, the first issue to be ascertained is whether the applicant can identify a rule of law which has been set down to protect the individual, much like the schutznorm or schutzgesetz. The rule of law for the protection of the individual has been confirmed to include fundamental rights in FIAMM, ${ }^{30}$ thereby crystallising the role of the principle of non-contractual liability in the protection of fundamental rights. The Court held in 2008 that:

"Also, a Community legislative measure whose application leads to restrictions of fundamental rights, such as the right to property and the freedom to pursue a trade or profession, that impair the very substance of those rights in a disproportionate and intolerable manner, perhaps precisely because no provision has been made for compensation calculated to avoid or remedy that impairment, could give rise to non-contractual liability on the part of the Community."

FIAMM establishes that damages may be claimed when a legislative measure is disproportionately limiting a fundamental right. This decision in FIAMM adds another important consideration as regards human rights claims. Whether a human right is violated is determined on the basis of the justifiable restrictions that are allowed by law to be imposed on that right. As it was explained in Chapter 4, Section (B), rights-conferring rules are self-referential as to the scope of the protected right. Legislation frequently refers to exemptions or reservations having in mind other legal rules, to which they accord precedence or regard as lex specialis. In the case of rights-related rules, the provision itself outlines the cases where the right may be limited. Therefore, there is no need to resort to any other type of unlawfulness, other than the inappropriate, or disproportional restriction of the right. For example, the right to private life may be restricted for the protection of a public interest, in a proportional manner. Absolute equality may also be restricted on the basis of positive discrimination or public interests. ${ }^{31}$ This is distinct from other legal rules of which the scope and application is dependent on other rules which may have superiority or which are regarded as lex specialis. Rights conferring provisions expressly outline the cases where the right may be limited.

\footnotetext{
${ }^{30}$ cf. FIAMM (n.23).

${ }^{31}$ See for example, Article 14(2) of the Recast Equal Treatment Directive, Article 4(1) of the Framework Directive 2000/78/EC, Article 52 of the Charter of Fundamental Rights.
} 


\section{The need for sufficiently serious breach - the human rights perspective}

Once the right-conferring rule is identified, the claimant must prove a "sufficiently serious breach" of that rule. This notion has also been subject to extensive interpretation and the meaning of "sufficiently serious breach" in rights-based cases is interpreted differently, which is the premise of this particular subsection.

Where the applicant is seeking compensation caused by an act adopted after the use of discretion, it is necessary to prove a "grave disregard of the limits of the discretion", ${ }^{32}$ for the breach to be judged as sufficiently serious. For non-discretionary acts, a mere infringement of the rightconferring rule may suffice to establish a "sufficiently serious breach". This subsection will specifically examine how the notion of "sufficiently serious breach" has been interpreted in human rights-related cases.

Arcelor $\mathrm{SA}^{33}$ is an important decision in this respect, because it unfolds the different meanings that 'sufficiently serious breach' may have, in particular as regards to human rights. The case included a claim that the provisions of a Directive concerned with greenhouse gasses emissions infringed the applicant's right to property, ${ }^{34}$ their freedom to pursue an economic activity ${ }^{35}$ and the principle of equal treatment. ${ }^{36}$

The Directive established national allocation plans of greenhouse gas emissions. The Member States would allocate allowances to private operators and there was also an emissions trading scheme for operators of installations, like the applicants. At the time, Arcelor was the largest steel producer worldwide. It initiated both an annulment action and an action for damages. In its claim for damages, Arcelor claimed that the Directive disproportionately restricted the substance of its right to property and its freedom to pursue an economic activity because it required the

32 cf. Bergaderm (n.4).

${ }^{33}$ cf. Arcelor (n.24).

${ }^{34}$ Today this is protected in Article 17 of the EU Charter of Fundamental Rights, although at the time the applicants based their application on the relevant constitutional and general principle of EU law as the Charter was not yet binding.

${ }^{35}$ Today this is protected in Article 16 of the EU Charter of Fundamental Rights, although at the time the applicants based their application on the relevant constitutional and general principle of EU law as the Charter was not yet binding.

${ }^{36}$ Today this is protected in Articles 20, 21 and 23 of the EU Charter of Fundamental Rights, although at the time the applicants based their application on the relevant constitutional and general principle of EU law as the Charter was not yet binding. 
applicant to operate its plants under economic conditions which were unsustainable. The applicants also claimed that the principle of equality was infringed because the Directive distinguished between steel producers and aluminum producers, while it also excluded the nonferrous metals and chemical products sectors despite these two emitting higher carbon dioxide rates than other producers.

As a starting point, the CFI took the following position on the meaning of a sufficiently serious breach:

$141 \ldots$ In relation to the requirement that there must be a sufficiently serious breach, the decisive criterion for establishing that a breach of Community law is sufficiently serious is whether the Community institution concerned manifestly and gravely disregarded the limits on its discretion. It is solely where that institution has only considerably reduced, or even no, discretion, that the mere infringement of Community law may suffice to establish the existence of a sufficiently serious breach (Case C-312/00 P Commission v Camar and Tico [2002] ECR I-11355, paragraph 54; Joined Cases T-198/95, T-171/96, T-230/97, T-174/98 and T-225/99 Comafrica and Dole Fresh Fruit Europe v Commission [2001] ECR II-1975, paragraph 134; Abad Pérez and Others v Council and Commission, cited in paragraph 132 above, paragraph 98; and É.R. and Others v Council and Commission, cited in paragraph 132 above, paragraph 100).”

Therefore, the CFI followed verbatim the interpretation laid down by Bergaderm, ${ }^{37}$ that a sufficiently serious breach is the grave disregard of the limits of the institution's discretion. However, the meaning of sufficiently serious breach takes a different hue in the subsequent paragraphs of the judgment where the alleged violations for the right to property, the freedom to pursue an economic activity and the principle of equal treatment were considered. The CFI rejected the applicant's arguments regarding the right to property on the basis that they had not proven that the action taken was disproportionate. More specifically, the CFI stated:

"153 It should be noted, at the outset, that, although the right to property and the freedom to pursue an economic activity form part of the general principles of Community

\footnotetext{
${ }^{37}$ cf. Bergaderm (n.4).
} 
law, those principles do not constitute absolute prerogatives, but must be viewed in relation to their social function. Consequently, the exercise of the right to property and the right to pursue a trade or profession freely may be restricted, provided that those restrictions in fact correspond to objectives of general interest pursued by the Community and that they do not constitute, with regard to the aim pursued, a disproportionate and intolerable interference which infringes upon the very substance of the rights guaranteed (see, to that effect, Case C-295/03 P Alessandrini and Others v Commission [2005] ECR I-5673, paragraph 86 and the case-law cited therein, and Chiquita Brands and Others v Commission, cited in paragraph 132 above, paragraph 220).

154 More specifically, in relation to the alleged infringement of the right to property, it should be noted that, apart from the very general claim that the contested provisions give rise to a situation in which the applicant is no longer able to exploit, in a profitable manner, its steel-production installations established within the internal market, the applicant has not made it clear to what extent its right to property in relation to certain tangible or intangible assets involved in its production process is actually affected or rendered meaningless as a result of the application or transposition into national law of those provisions. The applicant has also failed to indicate which production installations would be particularly affected by the contested provisions and why exactly those installations would be affected in the light of the individual situation of each of those installations in the territory within which they are established and in the light of the relevant NAP. In that regard, the applicant has merely stated, in vague terms, that it would not be able to close certain inefficient and non-profitable installations so as not to lose the emission allowances allocated to them, but it has failed to explain to what extent that lack of efficiency or profitability and the resulting economic difficulties are specifically attributable to the application of the contested provisions as such. According to its own assertions, those economic difficulties already existed well before the 2001 merger (see paragraph 30 above) and was one of the economic reasons behind that merger.

155 In addition, as regards the alleged violation of the right to property and the freedom to pursue an economic activity, taken together, the applicant has failed in both its written 
pleadings and at the hearing to explain in a plausible and substantiated manner how and to what extent, by reason of the implementation of the contested directive, it was likely to become a 'net purchaser of emissions allowances' unable to pass on its costs to its customers. The applicant did not claim that, during the first allocation period, which ended in 2007, it was obliged to purchase additional emissions allowances because of a possible allowance shortage in one of its production installations established in the internal market. On the contrary, at the hearing, in response to a question put by the Court, the applicant acknowledged that, in 2006, it had sold surplus allowances on the exchange market and made a profit of EUR 101 million, which was noted in the minutes of the hearing. Therefore, it cannot reasonably be claimed that, taken together, the contested provisions necessarily give rise to negative financial consequences which adversely affect the applicant's right to property and its freedom to pursue an economic activity.

156 In addition, it should be noted that the applicant has not claimed, within the context of its application for damages, that some of its production installations within the internal market had suffered losses due to the application of the contested provisions and it failed to produce precise figures in relation to the changes in the profitability of those installations since the allowance trading scheme became operational. The applicant also failed to provide information, first, on the way in which each of those installations had adapted to the different objectives of reducing emissions in the Member States concerned, some of which, such as the Kingdom of Spain, even have the possibility of increasing emissions in accordance with Decision 2002/358 and the burden-sharing agreement, and, second, on the question whether the emissions allowance quota to which it was entitled for those installations on the basis of the various NAPs was sufficient or not. Finally, even assuming that the various NAPs and the national reduction objectives are liable to infringe the applicant's rights, the latter has neither claimed nor shown that that infringement was attributable to the contested provisions as such and not to the national legislation which the Member States adopted in the exercise of their discretion with regard to the implementation of the contested directive under the third paragraph of Article 249 EC. 
157 As regards the applicant's argument that steel producers are unable, for technical and economic reasons, to reduce their $\mathrm{CO}_{2}$ emissions any further, it is sufficient to state that criterion 3 of Annex III to the contested directive requires the Member States, when determining the quantities of allowances to be allocated, to take account of the potential, including the technological potential, of activities covered by the allowance trading scheme to reduce emissions (see, to that effect, the Opinion of Advocate General Poiares Maduro in Arcelor Atlantique et Lorraine and Others, cited in paragraph 42 above, at point 57). It follows that, when allocating allowances to the various industrial sectors and to operators of installations within those sectors, the Member States have to take account of the reduction potential of all those sectors and operators, including that of the steel sector and of pig iron and steel producers. In addition, under criterion 7 of Annex III to the contested directive '[t]he [NAP] may accommodate early action [to reduce emissions]', with the result that the Member States have at least the possibility of taking account of efforts to reduce emissions which have already been made within the sector and by the operators at issue. Consequently, the possible failure on the part of the Member State to take sufficient account of that reduction capacity in its legislation transposing the contested directive cannot be attributed to the contested provisions.

158 In those circumstances, it appears that the contested provisions cannot infringe the applicant's right to property and its freedom to pursue a professional activity, or even that that alleged infringement is capable of causing it damage. It must therefore be concluded that the applicant has established neither a sufficiently serious breach or disproportionate restriction of those rights by the contested provisions nor that that alleged infringement may be the cause of the damage which it claims to have suffered."

Furthermore, this case also included a claim that the principle of equality was disregarded. The CFI referred to the earlier decision of the CJEU in Arcelor Atlantique in $2008 .^{38}$ It followed the decision of the CJEU in that the difference in treatment between two different sectors was justified on the basis of a substantial difference in the greenhouse gas emissions. The CFI therefore concluded that there was no infringement of the principle of equality.

\footnotetext{
${ }^{38}$ Case C-127/07 Arcelor Atlantique et Lorraine and Others [2008] ECR I-9895.
} 
This judgment demonstrates that the finding of unlawfulness was determined on pure human and fundamental rights terms - the arguments of the applicants for violations of the right to property and freedom to pursue a professional activity were rejected because there was no evidence of there being a disproportional limitation of those rights. Similarly, the issue of equality was determined on the basis that substantial differences justify differential treatment.

Another case, where the notion of a 'sufficiently serious breach' was interpreted to mean a disproportionate restriction in the context of a right-related action for damages is Ledra Advertising. ${ }^{39}$ The applicants (who included both a company as well as a number of natural persons) contended that their right to property ${ }^{40}$ was violated by the Commission and the ECB due to the Memorandum of Understanding that was adopted for the banking crisis in Cyprus, which resulted in a direct levy from the bank deposits of private individuals in order to help stabilising the banks. The General Court decided that the actions of the Commission and the ECB could not be subject to an action for damages since decisions within the framework of the European Stability Mechanism (ESM) fall outside the EU legal order, ${ }^{41}$ and this position was also supported by the Advocate's General Opinion during the appeal. ${ }^{42}$

The CJEU's judgment ${ }^{43}$ overruled the first instance decision saying that the framework of the ESM only excluded judicial scrutiny within the judicial review procedure but that it could not exclude non-contractual liability of the institutions. This confirms the approach taken that the non-contractual liability procedure is distinct to the judicial review procedure, ${ }^{44}$ as this procedure does not aim at the annulment of the act in question, but compensation. ${ }^{45}$ Nevertheless, no infringement of the right to property was found and as such the case failed in relation to the unlawfulness criterion:

\footnotetext{
39 Joined Cases C-8/15 P to C-10/15 P Ledra Advertising Ltd and Others $v$ European Commission and European Central Bank (ECB) Judgment of the Court (Grand Chamber) of 20 September 2016 ECLI:EU:C:2016:701.

${ }^{40}$ Article 17(1) of the EU Charter.

41 T-289/13, Ledra Advertising v Commission and ECB (EU:T:2014:981), of 10 November 2014, Eleftheriou and Papachristofi v Commission and ECB (T-291/13, not published, EU:T:2014:978), and of 10 November 2014, Theophilou v Commission and ECB (T-293/13, not published, EU:T:2014:979)

42 cf. Ledra Advertising (n.39).

${ }^{43}$ Ibid.

44 Joined Cases 197/80 to 200/80, 243/80, 245/80 and 247/80 Ludwigshafener Walzmühle Erling and Others v Council and Commission [1981] ECR 3211, paragraph 4; see also, to this effect, Case 175/84 Krohn Import-Export v Commission [1986] ECR 753, paragraph 32.

45 Joined Cases T-3/00 and T-337/04 Pitsiorlas v Council and ECB [2007] ECR II-4779, paragraph 283
} 
"68 It should therefore be examined whether the Commission contributed to a sufficiently serious breach of the appellants' right to property, within the meaning of Article 17(1) of the Charter, in the context of the adoption of the Memorandum of Understanding of 26 April 2013.

69 It must be remembered that the right to property guaranteed by that provision of the Charter is not absolute and that its exercise may be subject to restrictions justified by objectives of general interest pursued by the European Union (see judgments of 16 November 2011, Bank Melli Iran v Council, C-548/09 P, EU:C:2011:735, paragraph 113, and of 12 May 2016, Bank of Industry and Mine v Council, C-358/15 P, EU:C:2016:338, paragraph 55).

70 Consequently, as is apparent from Article 52(1) of the Charter, restrictions may be imposed on the exercise of the right to property, provided that the restrictions genuinely meet objectives of general interest and do not constitute, in relation to the aim pursued, a disproportionate and intolerable interference, impairing the very substance of the right guaranteed (see, to that effect, judgments of 16 November 2011, Bank Melli Iran v Council, C-548/09 P, EU:C:2011:735, paragraph 114, and of 12 May 2016, Bank of Industry and Mine v Council, C-358/15 P, EU:C:2016:338, paragraph 56).

71 As is apparent from Article 12 of the ESM Treaty, the adoption of a memorandum of understanding such as that resulting from the negotiations between the Cypriot authorities and, in particular, the Commission corresponds to an objective of general interest pursued by the European Union, namely the objective of ensuring the stability of the banking system of the euro area as a whole.

72 Indeed, financial services play a central role in the economy of the European Union. Banks and credit institutions are an essential source of funding for businesses that are active in the various markets. In addition, the banks are often interconnected and certain of their number operate internationally. That is why the failure of one or more banks is liable to spread rapidly to other banks, either in the Member State concerned or in other Member States. That is liable, in turn, to produce negative spill-over effects in 
other sectors of the economy (judgment of 19 July 2016, Kotnik and Others, C-526/14, EU:C:2016:570, paragraph 50).

73 In this instance, the measures identified in the disputed paragraphs provide in particular for the taking over, by Bank of Cyprus, of Cyprus Popular Bank's insured deposits, for the conversion of 37.5\% of Bank of Cyprus's uninsured deposits into shares with full voting and dividend rights, and for the temporary freezing of another part of those uninsured deposits, whilst it is stated that, should Bank of Cyprus be found to be overcapitalised relative to the core tier one target of $9 \%$ under stress, a buy-back of shares will be undertaken to refund holders of uninsured deposits by the amount of the overcapitalisation.

74 In view of the objective of ensuring the stability of the banking system in the euro area, and having regard to the imminent risk of financial losses to which depositors with the two banks concerned would have been exposed if the latter had failed, such measures do not constitute a disproportionate and intolerable interference impairing the very substance of the appellants' right to property. Consequently, they cannot be regarded as unjustified restrictions on that right (see, by analogy, judgment of 10 July 2003, Booker Aquaculture and Hydro Seafood, C-20/00 and C-64/00, EU:C:2003:397, paragraphs 79 to 86).

75 In the light of those factors, the Commission cannot be considered, by dint of having permitted the adoption of the disputed paragraphs, to have contributed to a breach of the appellants' right to property guaranteed by Article 17(1) of the Charter.

76 It follows that the first condition for establishing non-contractual liability of the European Union is not satisfied in this instance, so that the appellants' claims for compensation must be dismissed as lacking any foundation in law."

As such, in this case as well, the CJEU used the proportionality test as it is provided for by Article 52 of the EU Charter of Fundamental rights rather than the grave disregard to the limits of the institution's discretion in order to ascertain whether there has been a serious breach. It is clear and unequivocal from the CJEU's statement in paragraph 75 of the judgment that whether a 
breach has been committed by the Commission would be ascertained by whether its actions where within the prescribed general interests that can justify the restriction of the right to property. The CJEU went on to conduct the proportionality test to conclude that the stability of the economy of one Member State balanced the limitation of the individual's right to their deposits. The balancing exercise of the CJEU in this case was tilted towards economic interests rather than human rights. ${ }^{46}$

One could therefore observe that, where human rights cases are concerned, the test of "grave disregard of the limits of the discretion", which is mentioned in the case law, is to be interpreted on the basis of pure human rights terms - specifically the restrictions allowed by the legal norms which determine the scope of the right in question. This hypothesis is put forward in further detail in the Subsection D that follows, in relation to the distinction between discretionary and non-discretionary acts.

\section{Discretionary vs non- Discretionary acts - a redundant distinction for rights-based cases?}

Theoretically, there is a distinction between the test of discretionary and non-discretionary acts and the Courts ought to decide whether there is discretion in order to identify the applicable test. ${ }^{47}$ However, it appears that where the test of unlawfulness involves human rights, this distinction becomes blurred. Following the above analysis in Section $\mathrm{C}$, it is difficult to see, when rights claims are involved, what is the difference between the criterion 'mere infringement of a rule conferring rights to individual', used in cases where the action in question did not involve the use of discretion by the EU institution and 'a sufficiently serious breach of the rule conferring rights of the individual', used in cases where the action in question involved discretion, in order to establish the unlawfulness of that measure or action.

The Court that attempts to determine whether there is a violation of a right found in within the juridical order of the EU will use the same test - the one of disproportionate or unjustified limitation of a right, regardless of whether the challenged act is of a discretionary nature.

\footnotetext{
${ }^{46}$ P. Delmine, 'The end of impunity? The legal duties of "borrowed" EU institutions under the European stability mechanism framework (Case Comment)' (2017) 13(2) ECLR 369 - 382.

${ }^{47}$ Case T-390/94 Aloys Schroder v. Commission [1997] ECR II-501, Cases T-458 and 523/93 ENU v. Commission [1995] ECR II 2459, Case C-390/95 P Antillean Rice Mills NV v. Commission [1999] ECR I-769.
} 
This is due to the fact that human rights have self-referring standards by which a violation is determined, as it has been explained in Sections B and C, above. For example, whether there is a violation of the right to equality is a subjective question which includes the assessment of several factors, including situations where positive discrimination is necessary. ${ }^{48}$ The ECtHR, for example, has held that the State could treat men and women differently for purposes of positive discrimination in order to 'correct factual inequalities between them' ${ }^{\text {, }}$ - and that is a ruling which allows the limitation within the prescribed limits of Article 14 of the ECHR.

The right to a fair trial is again a right which encloses many sub-rights such as the right of access to a court, ${ }^{50}$ or the right to an impartial tribunal, a violation of which is substantiated, at least in Strasbourg, by whether the party may have legitimate doubts as to the impartiality of the court. ${ }^{51}$ In the EU, Article 47 of the Charter refers to a "fair and public hearing in a reasonable time by an independent and impartial tribunal." These rights conferring provisions and the case law applying them are self-referential as to the criteria of reasonable time and impartiality but make no reference to limitations that may be prescribed by law. The finding of a violation in this situation is made on a case by case basis. ${ }^{52}$

On the other hand, inhuman, degrading treatment or punishment, as protected by Article 4 of the Charter, is absolutely protected in human rights law and no deviation from that obligation is allowed, under any circumstances. ${ }^{53}$

An example where the General Court dealt with a non-discretionary act and discussed the selfreferential nature of fundamental rights was Sison. ${ }^{54}$ In this case, the applicant, Jose Maria Sison was a Filipino activist living in the Netherlands, whose assets were frozen by the Council by virtue of Article 2(3) of Regulation No 2580/2001, read in conjunction with Article 1(4) of

\footnotetext{
${ }^{48}$ See for example, Article 14(2) of the Recast Equal Treatment Directive, Article 4(1) of the Framework Directive 2000/78/EC, Article 52 of the Charter of Fundamental Rights.

${ }^{49}$ Stec and others v. United Kingdom (Apps 65731/01 and 65900/01) ECtHR12 April 2006 [GC] (2006) 43 EHRR 1017.

${ }^{50}$ Golder v. United Kingdom (App No. 4451/70) ECtHR. 21 February 1975 (1975) 1 EHRR 524.

${ }^{51}$ Piersack v. Belgium (Article 50) (App. 8692/79) ECtHR 26 October 1984.

${ }^{52}$ For example, the ECtHR in Texeira de Castro v. Portugal (App. 25829/94) ECtHR 9 June 1998 (1999) 28 EHRR 101, ECHR 1998 - IV, stated whether evidence taken by inappropriate methods is admissible or not thus infringing Article 6 ECHR, depends on whether the abuse of process was fundamental.

${ }^{53}$ Chahal v. UK (Application No 22414/93) ECtHR 15 November 1996 (1997) 23 EHRR 413, Saadi v. Italy (App. 32701/06) ECtHR 28 February 2008 [GC] (2009) 49 EHRR 730.

${ }^{54}$ Case T-341/07 José Maria Sison v. Council [2011] ECR II-07915.
} 
Common Position 2001/931. The applicant had invoked among other things that his rights to property and to private life had been violated.

In paragraph 35 of the judgment, the General Court reaffirmed that where the respondent institution has little or no discretion, then a mere infringement of EU law may suffice to establish a sufficiently serious breach. The General Court additionally noted that the Council, under Article 2(3) of Regulation 2580/2001 and Article 1(4) of the Common Position 2001/931, had little or no discretion as to the application of freezing measures on the persons listed. The General Court found that the inclusion of the applicant on the list of persons whose assets would be frozen, did not respect the conditions listed in Article 2(3) of Regulation 2580/2001 and Article 1(4) of the Common Position 2001/931, ${ }^{55}$ which also provided that public authorities could interfere with individuals' fundamental rights lawfully within the limits prescribed by human rights instruments.

However, despite the absence of discretion and the establishment of a prima facie infringement of Article 2(3) of Regulation 2580/2001 and Article 1(4) of the Common Position 2001/931 in principle, the General Court found that the infringement was not sufficiently serious as it was justified by the general interest of combating terrorism. ${ }^{56}$ As to human and fundamental rights, the General Court held that again no sufficiently serious breach existed for the same reason while it pointedly noted that:

"1 It may be added here that neither the Charter of Fundamental Rights of the European Union nor the ECHR, which both guarantee the right to effective judicial protection, preclude that the Community's non-contractual liability be made subject, in circumstances such as those of this case, to the finding of a sufficiently serious breach of the fundamental rights invoked by the applicant. With more particular regard to the rights guaranteed by Protocol No 1 to the ECHR, the European Court of Human Rights has, furthermore, taken account of 'the various inherent limitations imposed by the elements of the action to be established' (Bosphorus Hava Yollari Turizm ve Ticaret Anonim

\footnotetext{
${ }^{55}$ Interlocutory judgment in Case T-341/07 José Maria Sison v. Council [2009] ECR II-3625.

${ }^{56} \mathrm{Ibid}$, paragraph 62.
} 
Sirketi v. Ireland, ECHR judgment of 30 June 2005, Reports of Judgments and Decisions, 2005-VI, §§ 88, 163 and 165).”

The General Court therefore used the reasoning of a general interest of combating terrorism to justify the limitation of the applicant's fundamental rights. The general or public interest is one of the reasons for which both the right to property, ${ }^{57}$ and private life may be limited,${ }^{58}$ while Article 52(2) of the EU Charter of Fundamental Rights provides it as reason for the limitation of any right contained in the Charter. This case demonstrates that even where no discretion is involved, the Court chose to proceed to an assessment of a 'sufficiently serious breach' on the basis of human rights terms, even if a prima facie infringement of the rule was found.

In cases where the right to a fair trial is at stake the standards used by the Courts are also specific to the particular right. In Kendrion $N V v$. The European Union, ${ }^{59}$ the applicants brought a claim for non-contractual liability and complained that the procedure of adjudication by the General Court was so long that it violated the second paragraph of Article 47 of the EU Charter of Fundamental rights, which protects the right to judgment within a reasonable time. ${ }^{60}$ Within the framework of the procedure for non-contractual liability, the General Court found that indeed that right had been violated. The General Court found a violation on the basis that there was a period of inactivity of twenty months that could not be attributed to the conduct of the parties or justified in any way by the complexity of the case or any interim measures or decisions. ${ }^{61}$ The matter of discretion - which is inherent during any judicial procedure - had not been mentioned at all as a factor determining the test to be used to ascertain a sufficiently serious breach. The absence of justification for the delay was sufficient to establish a sufficiently serious breach of Article 47(2) of the Charter.

\footnotetext{
${ }^{57}$ Articles 17 and 52 EU Charter of Fundamental Rights, Article 1 Protocol 1 of the European Convention on Human Rights.

${ }^{58}$ Articles 7 and 52 of the EU Charter of Fundamental Rights, Article 8 of the European Convention on Human Rights.

59 Case T-479/14 Kendrion NV v. The European Union ECLI:EU:T:2017:48

${ }^{60}$ Article 47(2) of the Charter specifically states: 'Everyone is entitled to a fair and public hearing within a reasonable time by an independent and impartial tribunal.

${ }^{61}$ cf. Kendrion (n.59) $§ § 59-63$.
} 
Identical reasoning was also used by the General Court in Gascogne Deutschland, ${ }^{62}$ that concerned identical facts, and where the General Court stated:

"74 Finally, the degree of factual, legal and procedural complexity in Cases T-72/06 and T-79/06 is no justification for longer proceedings in this instance. In that regard, it should be noted in particular that, between the end of the written part of the procedure and the opening of the oral part of the procedure in Cases T-72/06 and T-79/06, the procedure was neither interrupted nor delayed by the Court's adoption of any measure in respect of its organisation.

75 As regards the conduct of the parties and the occurrence of procedural incidents in Cases T-72/06 and T-79/06, the fact that, in October 2010, the applicants requested the reopening of the oral part of the procedure is no justification for the three years and eight months which had already elapsed since the rejoinder was lodged. Furthermore, the fact that the applicants were notified in December 2010 that a hearing would be held in February 2011 indicates that that incident can have had only minimal effect on the length of time between the end of the written part of the procedure and the opening of the oral part of the procedure in those cases.

76 Consequently, in the light of the circumstances of Cases T-72/06 and T-79/06, the fact that 46 months elapsed between the end of the written part of the procedure and the opening of the oral part of the procedure shows that there was a period of unjustified inactivity of 20 months in each of those cases.

78 It follows that the procedure followed in Cases T-72/06 and T-79/06, which culminated in the delivery of the judgments of 16 November 2011, Groupe Gascogne v Commission (T-72/06, not published, EU:T:2011:671), and of 16 November 2011, Sachsa Verpackung v Commission (T-79/06, not published, EU:T:2011:674), infringed the second paragraph of Article 47 of the Charter of Fundamental Rights in that it

${ }^{62}$ Case T-577/2014 Judgment of the General Court (Third Chamber, Extended Composition) of 10 January 2017. Gascogne Sack Deutschland GmbH and Gascogne v European Union. ECLI:EU:T:2017:1. 
exceeded by 20 months the reasonable time for adjudicating, which constitutes a sufficiently serious breach of a rule of EU law intended to confer rights on individuals."

In none of these cases did the Court delve into the matter of discretion of the Court as a factor which would determine the standard or method of assessment of the existence of a violation of the rule invoked - which was a rule conferring rights on individuals. The Court directly used the standard of 'a sufficiently serious breach'.

Therefore, human rights law and specific human rights provisions have self-referring standards by which a violation may be found. This is of great importance in damages claims given that human rights obligations of the EU are codified in the EU Charter, the provisions of which may be invoked as the legal rule that has been violated. The distinction between discretionary and non-discretionary acts in this situation is of more limited utility than in other cases. The CJEU will therefore have to align its jurisprudence to fit these new circumstances.

In order to afford human and fundamental rights the value accorded to them by the provisions of the Treaties and the Charter, the CJEU may adopt the interpretation that a violation of a human or fundamental right is always considered to be a 'sufficiently serious violation', and that when the claim involves a fundamental right as the rule that has been violated, the test will not differ regardless of whether the act challenged is discretionary or not.

\section{E. Conclusion}

The core question of this Chapter is how the criterion of unlawfulness is interpreted by the Courts when the principle of non-contractual liability functions as a vehicle for the protection of human rights.

On the basis of the case law discussed above, including Arcelor Atlantique, ${ }^{63}$ Ledra Advertising ${ }^{64}$, Arcelor ${ }^{65}$ and Sison $^{66}$ it is evident that a finding of unlawfulness in all human rights cases is determined on pure human rights terms. Regardless whether the act in question is taken

\footnotetext{
${ }^{63}$ cf. Arcelor Atlantique (n.38).

${ }^{64}$ cf. Ledra Advertising (n.39).

${ }^{65}$ cf. Arcelor (n.24).

${ }^{66}$ cf. Sison (n.54).
} 
after the exercise of discretion or not, the Courts will determine the unlawfulness on the basis of the prescribed scope of that right and on whether the limitation to the relevant right may be justified on human rights terms, such as proportionality and the protection of a public interest.

Following this conclusion, significant academic and legal questions points must be made. One question is whether the CJEU should remain within the boundaries of its own well-established interpretative methods, ${ }^{67}$ or whether it should adopt a new approach regarding human rights, which would be more in line with international human rights law (for further analysis, see Part III of this Thesis). Indeed, this is of crucial importance where the EU's procedures, such as the action for damages, are being used as means of protection of human rights, invoking rightsconferring rules. In Samba Diouf $f^{68}$ Advocate General Cruz Villalon's position was that:

"once [a right] is recognised and guaranteed by the European Union, that fundamental right goes on to acquire a content of its own, the definition of which is certainly shaped by the international instruments on which that right is based, including, first and foremost, the ECHR, but also by the constitutional traditions from which the right in question stems and, together with them, the conceptual universe within which the defining principles of a State governed by the rule of law operate. This is in no way to disregard the very tradition represented by the acquis of over half a century of European Union law, which, as a system of law, has given rise to the development of its own set of defining principles."

In a similar reasoning in Melloni $^{69}$ Advocate General Bot mentioned that the interpretation of the Charter rights must tend towards a level of protection which accords with EU law. This approach in effect supports a standard of protection of Charter rights that will not compromise the core objective of the EU which is the creation of a common market and economic freedom. This approach may lead to a submission of human rights to economic freedoms within the EU's juridical order and undermine the efforts that have been made to give human and fundamental rights a constitutional value through the Charter and Article 6 TEU.

\footnotetext{
${ }^{67}$ W. Weiss, 'The EU Human Rights Regime Post Lisbon: Turning the CJEU into a Human Rights Court?' in S. Morano-Foadi and L. Vickers, Fundamental Rights in the EU - A Matter of two Courts (Hart Publishing 2015$) 86$.

${ }^{68}$ Case C-69/10 Samba Diouf, ECLI:EU:C:2011:524, Opinion of AG Cruz Villalon, §39.

${ }^{69}$ Case C-399/11 Melloni, EU:C:2013:107 Opinion of AG Bot, §106.
} 
If the CJEU moved from these positions and went on to embrace a human-rights based approach to change, for example, the distinction between discretionary and non-discretionary acts in damages procedures when the claim involved a human rights violation, it may become an effective judicial forum for applicants wishing to claim their rights when they believe those have been violated by the EU. The procedures of direct challenge of EU action, those being judicial review (discussed Part I of this Thesis) and the action for damages analysed in this Part, will thereby become more accessible and effective as mechanisms for the protection of human rights from EU action.

It has been claimed that the bindingness of the Charter and the new role of human rights in the EU require constitutional and human rights discourse ${ }^{70}$ and that the CJEU should begin functioning as a human rights court. ${ }^{71}$ What is necessary, however, is not that the CJEU should become a human rights court but rather that it should also be a human rights court, particularly when Union action is at stake. Indeed, the CJEU's jurisprudence demonstrates that the CJEU is starting to function as a human rights Court both in terms of the nature of cases it adjudicates as well as its deliberations.

In $C H E Z,^{72}$ a preliminary reference on the matter of discrimination against Roma people was brought for the first time before the CJEU. In a Roma inhabited area of Bulgaria, the national authorities placed electricity meters very high on poles, in order to prevent them from being stolen and destroyed, but making it also hard for citizens in that area to check their electricity consumption. The CJEU confirmed that the Roma were an 'ethnic origin' protected under EU anti-discrimination law held that even though the combat of crime was a goal of the EU, national Courts should assess such action on the basis of proportionality and stated that the practice was of "offensive and stigmatising nature". This case has been claimed to emphasise the role of the

\footnotetext{
${ }^{70}$ S. Iglesias Sanchez, 'The Court and the Charter: The Impact of the Entry into Force of the Lisbon Treaty on the ECJ's Approach to Fundamental Rights' (2012) 49 CMLRev 1578.

${ }^{71}$ cf. Weiss (n.67) 88.

${ }^{72}$ Case C-83/14 CHEZ Razpredelenie Bulgaria AD v Komisia za zashtita ot diskriminatsia [2016] 1 CMLR 14
} 
CJEU as an alternative human rights court in Europe. ${ }^{73}$ Other commentators point to the fact that EU law and the CJEU's deliberations are now being referred to in Strasbourg. ${ }^{74}$

It may be that the CJEU is making indeed bold deliberations, in line with the fact that the EU claims to be a strong proponent of human rights. ${ }^{75}$ However, the crucial point here is not that the CJEU should become a human rights court which will function as an alternative to Strasbourg, when the EU Member States do not apply human-rights related EU law, or a Court enslaved to human rights discourse, losing its initial purpose.

Rather, the CJEU should modernise its interpretation and doctrine regarding traditional EU law procedures that concern the judicial scrutiny of the Union's own actions, such as the action for damages, or the action for annulment, in order to make the principles applied in these procedures respond effectively to the status of human rights within EU law. This is perhaps starting to happen, having in mind the fact that in cases such as Arcelor ${ }^{76}$ and Ledra Advertising ${ }^{77}$, unlawfulness was determined in pure human rights terms.

Nevertheless, these cases also prove that despite the intense human rights narrative employed by the Court where the Union's actions are not at stake, the finding of unlawfulness of Union action through the proportionality review, may serve the CJEU's persisting partiality to economic freedoms rather than rights. Within that discretion, for example, in Ledra Advertising, ${ }^{78}$ it found that the welfare of the economy prevailed over the property rights and thus justified the direct collection of individuals' life savings for the purposes of securing economic stability.

\footnotetext{
${ }^{73}$ A. Oliveira and S-J. King, 'A good chess opening: Luxembourg's first Roma case consolidates its role as a fundamental rights court (Case Comment)' (2016) 41(6) ELR 865-884, 880.

${ }^{74}$ T. Lock, 'The influence of EU law on Strasbourg doctrines' (2016) 41(6) ELR 804-825.

${ }^{75}$ Article 2 TEU, Article 3(5) TEU.

${ }^{76}$ cf. (n.24).

77 cf. (n.39).

${ }^{78}$ Ibid.
} 


\section{Chapter 6}

\section{Damage, causation and the principle of non-contractual liability of the EU vis-à-vis human rights claims}

\section{A. Introduction}

This Chapter will explore how the concepts of 'damage' and 'causation' within the principle of non-contractual liability interact with the protection of human rights in the EU. A central research question within this Section is the meaning of 'damage' when the case brought before the EU courts is concerned with the protection or violation of a right.

Section (B) will introduce the topic of damage in non-contractual liability procedures and particularly how damage related to human rights violations is treated in the case law. Section (C) will explore the concept of causation and, more specifically, the way the Courts have interpreted causation in non-contractual liability claims related to human rights. Section (D) will return to the concept of damage and examine how it may be related to the concept of unlawfulness when the non-contractual liability claim is rights-based. Following this analysis Section (E) will delve into the issue of declaratory judgments and nominal damages and how this could or should play a role for the protection of human rights within the non-contractual liability system. Section (F) will conclude with some observations and suggestions in relation to the jurisprudential approach to the relationship of the concepts of damage and causation to the protection of human rights.

\section{B. Remediable Damage and Human Rights}

When an applicant brings a claim for non-contractual liability of the Union, she must establish that she has suffered some form of damage. Therefore the burden of proof rests with the applicant - it is for the party seeking to establish the Union's liability to adduce conclusive proof as to the existence or extent of the damage. ${ }^{1}$ This is provided by Article 21 of the Statute of the

\footnotetext{
${ }^{1}$ Case T-271/04 Citymo SA v Commission of the European Communities [2007] ECR II-01375 Para. 159
} 
Court of Justice. ${ }^{2}$ No non-contractual liability claim may be successful unless the harm is clearly identified in the application. ${ }^{3}$ Once the unlawfulness of the action is established, the applicant should prove that she suffered damage which is certain, ${ }^{4}$ specific, ${ }^{5}$ proven ${ }^{6}$ and quantifiable, ${ }^{7}$ and that there was a causal link between the unlawful act and the damage sustained. ${ }^{8}$

Damage is certain if, according to the Court, it is foreseeable with sufficient certainty even if it cannot yet be precisely assessed. ${ }^{9}$ This means that as regards the requirement of damage the CJEU has taken an identical view as the French law of civil responsibility, whereby the Court may still decide to order compensation for damage which has not occurred at the time of the dispute, but which will unavoidably appear in the future. ${ }^{10}$ This approach was adopted also as to the nature of the damage that may be claimed. In Ireks - Arkady ${ }^{11}$ the court held that

“...the concept of 'damage' covers both a material loss stricto sensu, that is to say a reduction in a person's asset, and also the loss of an increase in those assets which would have occurred if the harmful act had not taken place (these two alternatives are known as damnum emergens and lucrum cessans)... The object of compensation is to restore the assets of the victim to the condition in which they would have been apart from the unlawful act"

Therefore, the Court has expressly accepted losses of future gains as a remediable damage.

\footnotetext{
2 Case T-19/01 Chiquita Brands and Others v Commission [2005] ECR II-315, paragraphs 64 and 65; Case T-279/03 Galileo International Technology and Others v Commission [2006] ECR II-1291, paragraphs 36 and 37 ; Case T-304/01 Abad Pérez and Others v Council and Commission [2006] ECR II-4857, paragraph 44; Case T-138/03 É.R. and Others v Council and Commission [2006] ECR II-4923.

${ }^{3}$ Joined Cases C-12/13 P and C-13/13 P Gérard Buono and Others v European Commission Judgment of the Court (Grand Chamber) of 14 October 2014, paras 35-39.

4 Cases 56-60/74 Kampffmeyer v. Commission and Council [1976] ECR 711,

5 Ibid.

6 Case Fux v. Commission [1969] ECR 145.

7 See AG's Capotorti Opinion in Case 238/78 Ireks-Arkady v. Council and Commission [1979] ECR 2955.

8 Cases 64, 113/76, 167, 27, 28, and 45/79 Dumortier Frères SA v. Council [1979] ECR 3091.

9 Ibid.

${ }^{10}$ See M. Fabre-Magnan, Droit Des Obligations 2 - Responsabilité civile et quasi-contrats (PUF 2édition, 2010) 132 «Un préjudice non encore survenu au moment de l'accident, ou plus précisément au moment où le juge statue, i.e. un préjudice futur, peut d'ores et déjà être réparé... dès lors qu'on est certain de sa survenance future, c'est-àdire qu'il n'est plus temps de l'éviter et qu'il va nécessairement apparaître."

${ }^{11}$ cf. Ireks-Arkady (n.7).
} 
An important challenge in human rights claims is that the damage claimed may be of a nonmaterial nature which cannot be measured in terms of assets. For example, there may be a claim by the relatives of a person who have suffered significant health damage. These applicants may claim that their private and family life has been compromised as a result of the first victim's injury. This raises some questions: to what extent the compromise of a right such as the one of private life is a quantifiable damage, but also to what extent there is a causal link between the initial loss suffered and the one claimed.

Where non-quantifiable damage that cannot be conclusively proven is concerned, the position of the case law expressed in SELEX Sistemi Integrati ${ }^{12}$ is that the applicant must at least provide evidence that the conduct is such so as to cause that damage:

"38. It is without error of law and with reasoning free of any contradiction, that in terms of the non-material damage the Court of First Instance decided that in substance, in points 33 and 36 of the order appealed against, that, if the presentation of evidence is not necessarily considered to be a condition of the recognition of such damage, it is still the duty of the applicant to establish that the conduct attributed to the institution concerned was of such nature so as to cause it such damage"

This approach has also been adopted by the General Court of the EU in Gascogne Deutschland ${ }^{13}$

"151 It follows from case-law that, where an applicant has put forward nothing to show the existence of its non-material damage or to establish its extent, it falls to it, at the very least, to prove that the conduct of which it complains was, by reason of its gravity, such as to cause it damage of that kind (see, t that effect, judgments of 16 July 2009, SELEX Sistemi Integrati v Commission, C-481/07 P, not published, EU:C:2009:461, paragraph 38; of 28 February 1999, BAI v Commission, T-230/95, EU:T:1999:11,

\footnotetext{
12 C-481/07 P, EU:C:2009:461 "De même, c'est sans commettre d'erreur de droit et par des motifs exempts de contradiction que, s'agissant du préjudice moral, le Tribunal a jugé en substance, aux points 33 et 36 de l'ordonnance attaquée, que, si la présentation d'une offre de preuve n'est pas nécessairement considérée comme une condition de la reconnaissance d'un tel préjudice, il incombe tout au moins à la partie requérante d'établir que le comportement reproché à l'institution concernée était de nature à lui causer un tel préjudice.»

${ }^{13}$ Case T-577/14 Gascogne Sack Deutschland GmbH and Gascogne v European Union ECLI:EU:T:2017:1
} 
paragraph 39; and of 16 October 2014, Evropaïki Dynamiki v Commission, T-297/12, not published, EU:T:2014:888, paragraphs 31, 46 and 63).”

This approach taken by the case law may be beneficial to human rights claims in light of the fact that non-material damage, where for example privacy or the right to equality have been violated, is difficult to be proven with quantifiable factors. However, the wording employed by the courts on both occasions is restrictive in that the applicant ought to prove at the very least that the conduct, by reason of its gravity was such as to cause it the damage of that kind.

Therefore, the concept of remediable damage is a relatively narrow notion which has been strictly construed by the courts. The fact that the violation of certain human rights, such as the right to equality, the freedom of expression or religion or the right to private life is not always followed by material or economic damage that may be quantifiable may limit the effectiveness of the action for damages procedure in protecting human and fundamental rights. This will be examined in further detail in sections (D) and (E) which delve into a detailed discussion of the relationship between the concepts of 'damage' and 'violation of a right' within the context of Article 340.

\section{Causation and human rights}

1. "Damage following directly or sufficiently directly"

Much like domestic civil responsibility systems, the proof of moral, material, economic or physical damage and the causal link between it and the challenged act may be hard to establish. Union Courts take a strict approach to the issue of causation. ${ }^{14}$ It is not enough that the damage would not have occurred but for the Union action (conditio sine qua non). ${ }^{15}$ The CFI in Atlantic Container Line ${ }^{16}$ had stated that the 'but for' test is too broad a definition to be applied in the context of an Article 340 action and that Union liability relates only to:

“... damage flowing directly, or sufficiently directly from the conduct of the institution concerned which is complained of, which in particular, precludes that

\footnotetext{
${ }^{14}$ van Dam C., European Tort Law (2 ${ }^{\text {nd }}$ edition, OUP, 2013) 322.

${ }^{15}$ Case T-478/93 Wafer Zoo v. Commission ECR 1995 II-1479.

16 Case T-113/04 Atlantic Container Line AB and Others v. Commission [2007] E.C.R II-171.
} 
liability from covering damage which arises only as a remote consequence of that conduct."

When it comes to moral damage which may be caused by the violation of a human right, the test as explained in Section (B) above is that at the very least the applicant must prove that the conduct of the institution concerned must be so grave as to cause the damage that the applicant claims. ${ }^{17}$ While this approach may seem broad, it yet requires the minimum threshold of proving that the conduct of the institution was so grave so as to cause the damage alleged. What perhaps could be concluded from this is that a grave violation of a right may be sufficient so as to prove damage and causation together. However, the criteria for determining the required gravity of the violation are not evident in the case law.

\section{Indirectly caused damage and human rights}

The Court has held that damage that an individual passes on to others, ${ }^{18}$ or that is indirectly caused to a person, is not eligible for compensation. Indirectly caused damage may appear in human rights cases, as the applicants will occasionally seek redress for an act that does not concern them directly or is not aimed at them, but which has had an impact on how they live their lives.

In Leussink, ${ }^{19}$ the case concerned the moral damage caused to one's relatives by an act that caused injury to the initial applicant. An official of the European Community was injured and his wife and children claimed compensation for the disturbance of their family life due to their respective husband's and father's change of personality. At the time, human rights formed part of the general principles of EU law, without being however, incorporated in the Charter. The Court held that it does not grant compensation for non-material damage which is indirectly caused by the unlawful action (indirect victims or victimes par ricochet in common law and civil law respectively).

\footnotetext{
${ }^{17}$ Ibid and cf (n.12) SELEX Sistemi Integrati.

${ }^{18}$ cf. Ireks Arkady (n.7).

${ }^{19}$ Cases 169/83 and 136/84 Gerhardus Leussink and others $v$ Commission of the European Communities. Officials [1986] ECR 1986-02801
} 
In Franchet ${ }^{20}$ Court came across a situation where some of the applicants claimed to have suffered damage due to moral damage suffered by the initial applicants. The Court of First Instance rejected that the leaking of confidential information during investigative procedures against Union officials could cause non-material damage to close relatives, while it accepted the claim for the individuals who were directly concerned. The CFI in this case held that the claim regarding the damage suffered by the close relatives of the directly affected individual could not succeed since they were not supported by any firm evidence of a link between the investigative or disciplinary procedures against the officials. ${ }^{21}$

In its judgment the CFI made reference to its earlier decision in Zavvos ${ }^{22}$ where it had also underlined the importance of the causal link between the damage claimed and the act of the Union, saying that no concrete piece of evidence links an act of the Union with the moral damage alleged by persons related to the initial applicant. However, it must be pointed out that this approach fails to take into account the rights of family members vis-à-vis action taken against their relatives.

With the same reasoning, the Court held in the mad cow disease case that non-contractual liability does not cover relatives who are indirectly affected by the unlawful conduct and did not recognise the fear of infection as a remediable damage. ${ }^{23}$ In FIAMM $^{24}$ the Court had stated:

" $185 \ldots .$. The Court has also stated that the guarantees accorded by the right to property or by the general principle safeguarding the freedom to pursue a trade or profession cannot be extended to protect mere commercial interests or opportunities, the uncertainties of which are part of the very essence of economic activity (Case 4/73 Nold v Commission [1974] ECR 491, paragraph 14)."

The case law described above, including the causation test but also the examples where claims were brought by persons close to the individuals affected demonstrate the Court's firm position

${ }^{20}$ Case T-48/05 Yves Franchet and Daniel Byk v Commission of the European Communities [2008] ECR II-01585.

${ }^{21}$ Ibid $\$ 411$.

${ }^{22}$ Case T-21/01 Zavvos v Commission [2002] ECR-SC I-A-101 and II-483,

${ }^{23}$ cf. É.R. (n.2)

${ }^{24}$ Joined Cases C 120/06 and C121/06 FIAMM and Others v. Council and Commission [2008] ECR I-06513. 
not to remedy damage which may be too remote from the unlawful act or conduct. ${ }^{25}$ This is a potential drawback under the new circumstances where fundamental rights are involved, which are undoubtedly broader notions compared to the traditional civil responsibility principles.

\section{Expansion of EU policies, causation and human rights}

Furthermore, expansion of EU policies has brought cases for non-contractual liability of various types before the Courts - including cases that involved human rights and the Union's external action. In $\mathrm{Zaoui}^{26}$ the applicants sought compensation for the damage caused by a terrorist act by Palestinian Hamas in Israel. Their action was directed against the EU (then Community) claiming that the EU contributed to the damage by granting financial aid to the Palestinian Authority for education, which in turn incited hatred and caused the attacks in question. The CJEU dismissed the case since there was no proven sufficient causal link between the EU's conduct and the damage caused.

In Mugraby ${ }^{27}$, the applicants' claim was that the EU failed to respect an Association Agreement with Lebanon which provided for dialogue between Lebanon and the EU on the basis of democratic principles to foster prosperity for the people of Lebanon. The applicant suffered a denial of justice in Lebanon, which according to him was known by the EU which did not take action, and that in turn was a violation of the agreement and an infringement of fundamental rights, for which he claimed damages. The GCEU held that such a claim was unfounded as it was not sufficiently precise and this position was upheld by the CJEU. ${ }^{28}$

The cases of Zaoui, ${ }^{29}$ and Mugraby, ${ }^{30}$ are an example of how the EU's international action may affect human rights and how international human rights responsibilities may have an interplay with internal EU procedures for liability (for a more detailed analysis of the international legal responsibility of the EU in relation to human rights, see Part III). A valid observation that has

${ }^{25}$ K. Lenaerts, I. Maselis, K. Gutman and J.T. Nowak, EU Procedural Law (OUP 2014) 541

${ }^{26}$ Case C-288/03 P Zaoui v. Commission Order of the Court, 14 October 2004.

${ }^{27}$ Case T-292/09, Mugraby [2011] ECR II-255 (Gen. Ct, Order, 6 Sept. 2011); Case C-581/11 P, Mugraby, not yet reported (Grand Chamber, Order, 12 July 2012).

${ }^{28}$ Ibid.

${ }^{29} \mathrm{cf}$ (n.26).

${ }^{30}$ cf. (n.27). 
been made is that with regard to external action, international organisations should be able to foresee the human rights implications that their actions in other countries may have. ${ }^{31}$

\section{D. 'Damage' and 'Unlawfulness' - may they be the same concept in fundamental rights claims?}

This Section will delve into the theoretical question of whether, within the context of noncontractual liability, the finding of the breach of a right may also be considered damage for the purposes of compensation. Something which ought to be considered here is whether, when the legal rule which is alleged to have been infringed concerns human rights, and the infringement is established as part of the tripartite test, it would be enough to say that the damage is established, as the violation of a right may be considered as remediable damage per se. What is evident thus far is that the traditional approach of the CJEU has been to distinguish between the concept of unlawfulness and damage per se. It may be necessary that the EU judicature starts to embrace new possible dimensions of the notion of 'damage' following the role that fundamental rights may play in an action for damages.

The traditional stance of the CJEU may be seen in Arcelor $S A^{32}$ and in FIAMM, ${ }^{33}$ where the claims were rejected at the point of proving unlawfulness, while in Nikolaou ${ }^{34}$ the Court accepted the claim for non-material damage.

The CJEU has so far treated the violation of a right and the damage arising, as two separate questions where the proof of one does not necessarily suffice for the other. The most traditional view is that there is no causation when the same result would have occurred even in the absence of a wrongful act or omission, and if the wrongful act or omission is only one of several circumstances, causation is not necessarily proven, either. ${ }^{35}$

\footnotetext{
${ }^{31}$ Bulterman M. in de Schutter O. and Alston P. (eds) Monitoring Fundamental Rights in the EU - The Contribution of the Fundamental Rights Agency (Hart Publishing 2005), 258.

${ }^{32}$ Case T-16/04 Arcelor SA v. European Parliament and Council [2010] ECR II-211 [97].

${ }_{33}^{33}$ Joined Cases C 120/06 and C121/06 FIAMM and Others v. Council and Commission [2008] ECR I-06513

${ }^{34}$ Case T-259/03 Kalliopi Nikolaou v. Commission [2007] ECR II-00099.

${ }^{35}$ A.G. Toth, 'The Concepts of Damage and Causality as Elements of Non-Contractual Liability', in T. Heukels and A. Mc Donnel (eds) The Action for Damages in Community Law (Kluwer 1997) 192.
} 
The damage must be proven by evidence, even if the action is established to be infringing fundamental rights. In Groupe Gascogne, ${ }^{36}$ the applicant had claimed, in their appeal from the GCEU to the CJEU that the lengthy proceedings in the GCEU violated the right to a fair trial as guaranteed by Article 47 of the Charter. The CJEU considered that this was subject to a separate procedure and should not be included in an appeal and that

"88 It will also be for the General Court to assess both the actual existence of the harm alleged and the causal connection between that harm and the excessive length of the legal proceedings in dispute by examining the evidence submitted for that purpose."

According to this perspective the concepts of damage and unlawfulness remain separate even where fundamental rights are involved. At this point it is necessary to underline that the CJEU does not grant nominal damages for the mere infringement of a legal right (see detailed discussion in section E below) ${ }^{37}$

In Roquette, ${ }^{38}$ the applicant had claimed that he was entitled to nominal damages since the wrongful act of the institution was in itself a form of damage suffered. The Court's response was that even where the applicant reduces the claim to nominal damages does not relieve the applicant of providing conclusive proof of the damage suffered. Nevertheless, the violation of one's family life, for example cannot always be fully proven by conclusive proof. Therefore, one can point out that the overly materialistic approach taken by the Court does not fit well with the more abstract nature of the damage that will be included in a potential fundamental rights claim.

Later case law, has demonstrated a shift by appreciating the gravity of a violation of a fundamental right, and showing an understanding of it being damage in itself. There are examples where the Courts have described the unlawfulness as enclosing or encompassing within it a form of damage. In Psarras, ${ }^{39}$ the Civil Service Tribunal, after ruling that the

36 Case C-58/12 P Groupe Gascogne SA v European Commission [2014] 4 CMLR 14.

${ }^{37}$ cf. van Dam (n.14) 360.

38 Case 26/74 Roquette v. Commission ECR 1976, 677, 688.

39 Case F-63/13 Aristidis Psarras v European Union Agency for Network and Information Security (ENISA), Judgment of the Civil Service Tribunal (First Chamber) of 2 July 2014, para 54 where the Tribunal stated «S'agissant des conclusions tendant à la condamnation de l'ENISA à réparer le préjudice moral résultant de l'illégalité de la décision du 4 septembre 2012, il convient de rappeler que, selon une jurisprudence constante, l'annulation d'un acte entaché d'illégalité peut constituer en elle-même la réparation adéquate et, en principe, 
procedural fundamental rights of the applicant under Article 41 of the Charter had been violated, held that the annulment of an unlawful act may be seen as a form of reparation for the moral harm suffered but that compensation will be granted where the applicant proves that the moral damage they have suffered can be 'separated' from the illegality of the decision which has been annulled. This approach, although not substantially deviating from the traditional viewpoint that damage must be conclusively proven beyond the finding of unlawfulness, reveals an understanding that unlawfulness - in specific the case of fundamental rights, a violation - is a form of moral damage.

The decision of the GCEU in Gascogne Sack Deutschland GmbH and Gascogne v European Union $^{40}$ further demonstrates an understanding by the EU's judiciary that the infringement of a fundamental right is moral damage in itself. In this case, following the decision of the CJEU in Groupe Gascogne ${ }^{41}$ that the matter of damage caused by unreasonable delays in adjudication by the General Court, contrary to Article 47 of the Charter, was a separate matter to be determined in an action for damages and not within the framework of an appeal; the applicants brought a new action for damages before the GCEU.

The applicants complained that the failure of the GCEU in Cases T-72/06 and T-79/06, involving the applicants, to deliver a judgment within a reasonable time was contrary to Article 47(2) of the EU Charter of Fundamental Rights which provides that everyone is entitled to a hearing within a reasonable time. The applicants claimed reparation, for they maintained that the delay caused them reputational damage and placed them in a position of uncertainty. Indeed, the GCEU found that Article 47(2) of the EU Charter of Fundamental Rights had been violated as the delivery of the relevant judgments exceeded by 20 months the average reasonable time for adjudication. $^{42}$

In terms of the damage claimed, the GCEU firstly pointed out that where the damage or its extent may not be precisely proven then the applicant must prove that the unlawful conduct is grave

suffisante de tout préjudice moral que cet acte peut avoir causé, à moins que le requérant ne démontre avoir subi un préjudice moral détachable de l'illégalité fondant l'annulation et insusceptible d'être intégralement réparé par cette annulation (voir arrêt CH/Parlement, EU:F:2013:203, point 64) ».

40 Case T-577/2014 Judgment of the General Court (Third Chamber, Extended Composition) of 10 January 2017.ECLI:EU:T:2017:1

${ }^{41} \mathrm{cf}$ (n.36).

42 Ibid, $\$ 78$. 
enough such as to cause damage of that kind claimed. ${ }^{43}$ This differs from the approach taken in Roquette, where the position expressed was that even where the applicant 'has reduced their claim to nominal damages, it does not relieve them from providing conclusive proof of the damage suffered.' 44

The GCEU found that the harm to reputation was not proven as the applicants had only referred to the harm to their reputation in an abstract way. Nevertheless, it linked the finding of unlawfulness to reputational damage by stating that the finding of the Court of an unjustified delay would make good any reputational damage. ${ }^{45}$ The precise terminology used by the Court was:

"153 Consequently, the applicants have not demonstrated that the breach of the obligation to adjudicate within a reasonable time in Cases T-72/06 and T-79/06 was such as to harm their reputation.

154 In any event, in the present case, the finding in paragraph 78 above that there has been a breach of the obligation to adjudicate within a reasonable time would, in the light of the gravity of that breach, be sufficient to make good the reputational harm alleged by the applicants."

The Court furthermore pointed out that the moral damage effectively suffered during the delay, namely the state of uncertainty that the delay plunged the applicants in, constituted moral damage worthy of actual compensation beyond the finding of a breach of the applicants' right:

"156 However, the proceedings in Cases T-72/06 and T-79/06, which lasted five years and nine months, were longer than the applicants could have anticipated that they would be, in particular at the time when they brought their actions. Furthermore, it is apparent from the proceedings in Cases T-72.06 and T-79/06 that a period of three years and 10 months elapsed between the end of the written part of the procedure and the opening of the oral part of the procedure. Those periods are not in any way justified by the adoption

\footnotetext{
${ }^{43}$ Ibid, $\$ 151$.

${ }^{44} \mathrm{cf}$ (n.38) point 24.

${ }^{45} \mathrm{Ibid}$, point 153.
} 
of measures of organisation of procedure or measures of inquiry or the occurrence of procedural incidents.

157 In those circumstances, the failure to adjudicate within a reasonable time in Cases T-72/06 and T-79/06 was such as to put the applicants in a position of uncertainty greater than that normally engendered by court proceedings. That prolonged state of uncertainty inevitably had an impact on decision-making and the running of those businesses and therefore constituted non-material damage.

158 In the third place, in the circumstances of the present case, the non-material damage suffered by the applicants as a result of the prolonged state of uncertainty in which they were placed is not fully compensated by the finding of a breach of the obligation to adjudicate within a reasonable time." 46

The case of Safa Nicu Sepahan, ${ }^{47}$ also reveals the approach taken by the EU's courts that the finding of unlawfulness per se may lead to compensation, but if it is deemed that the finding itself is not sufficient to compensate the non-material damage caused. At the level of the General Court, the applicants had claimed that their inclusion in the list of persons under restrictive measures infringed the safeguards of effective judicial protection included in Regulation No 961/10 and Regulation No 267/2012, embodying the rights contained in Articles 47 and 48 of the EU Charter. Their action sought two remedies: compensation by virtue of Article 340 TFEU and annulment on the basis of Article 263 TFEU. The General Court first dealt with the latter, finding a violation and annulling the act.

In their claim for compensation, the applicants sought compensation for non-material damage, specifically stating that the imposition of restrictive measures and their alleged association with nuclear activities infringed their personality rights. ${ }^{48}$ The General Court made an important observation as to this matter:

\footnotetext{
46 Ibid, 156. Identical reasoning was used by the General Court in Kendrion NV v. The European Union ECLI:EU:T:2017:48 §129.

${ }^{47}$ Case T-384/11 Safa Nicu Sepahan Co. v Council of the European Union ECLI:EU:T:2014:986.

${ }^{48} \mathrm{Ibid}, \S 78$.
} 
"88. It is apparent from the documents before the Court that the allegation that the applicant was involved in nuclear proliferation affected the way in which third parties, located for the most part outside the European Union, behaved towards it. Those effects, which lasted for almost three years and are the cause of the non-material damage suffered by the applicant, cannot be wholly offset by a subsequent finding that the contested acts are unlawful, given that the adoption of restrictive measures against an entity tends to attract more attention and provoke a greater reaction, in particular outside the European Union, than does their subsequent annulment.

89. It must also be observed, first, that the allegation levelled by the Council at the applicant is particularly serious inasmuch as it associates it with Iranian nuclear proliferation, in other words, an activity representing, in the Council's view, a threat to international peace and security.

$90 \mathrm{Next}$, as is clear from paragraphs 32 to 38 above, the allegation which the Council levels at the applicant has not been substantiated by any relevant information or evidence.

91 Finally, although the listing of the applicant's name, which was published in the Official Journal, could have been withdrawn by the Council at any time, it was maintained for almost three years despite the applicant's objections. In that regard, the file does not contain anything which suggests that the Council, either on its own initiative or in response to the applicant's objections, checked whether that allegation was well founded in order to limit the harmful consequences which it would entail for the applicant.

92 Accordingly, evaluating the non-material harm suffered by the applicant ex æquo et bono, the Court considers that an award of EUR 50000 would constitute appropriate compensation.

Therefore, the General Court found that the existence of an unlawful act is in itself something which may be deemed remediable: the Court gave emphasis to the fact that the allegation of 
nuclear proliferation was very serious and the Council's failure to ensure that their inclusion in the list for restrictive measures was duly justified so as to limit harmful consequences, was nonmaterial damage to be compensated. It must be, however, pointed out that the General Court made no express recognition of a violation of 'personality rights' despite the positive approach it took to associating the concepts of unlawfulness and damage. Upon appeal, the CJEU upheld and adopted the General Court's approach to the applicants' arguments. ${ }^{49}$

The essence of the case law discussed above is that although the EU's judiciary has not officially deviated from the principle that the requirements for finding non-contractual liability are three, it has shown to some extent an understanding that where the case involves fundamental rights, unlawfulness encompasses in itself a non-material damage to one's rights. A shift towards a stance that would expressly allow for compensation for a violation of a right would be a very positive development in the protection of human rights vis-à-vis action of EU institutions.

The need for a broader and a perhaps more anthropocentric approach by the CJEU in order to respond effectively to the human rights obligations of the Union's institutions is further accentuated if the approach of the CJEU regarding the issue of nominal damages and declaratory judgments, is compared to the one taken by national courts and the ECtHR.

\section{E. Comparing the CJEU's approach to damages for the vindication of a right per se with domestic law and European human rights law}

The connection between a person's legal rights and the right to compensation is highlighted by the fact that damages are indeed the recognition that the applicant, victim, or claimant has had her rights infringed. ${ }^{50}$ Law as a system is not only there to protect financial interests and priced possessions - its role expands to the satisfaction and comfort an individual obtains from the recognition that she was not treated as she ought to. This particular satisfaction is offered by the judicial protection of legal rights.

This subsection will compare the approach taken by the CJEU on the matter of nominal damages as a remedy which aims at recognising the violation of a right with the English and French legal

49 Case C-45/15 P Safa Nicu Sepahan Co. v Council of the European Union ECLI:EU:C:2017:402

50 cf. van Dam (n.14) 349. 
systems as well as the European Court of Human Rights. By drawing this comparison, one may assess to what extent the CJEU's approach on the matter of damages for the pure violation of a right is in line with European human rights law as well as the legal principles of the Member States, and whether the CJEU should make more progress in that area to substantively offer a remedy for human rights violations by EU institutions through the action for damages procedure.

\section{Domestic Legal Systems}

Several European domestic legal systems recognise the significance of compensating the infringement of a legal right per se. English law has nominal damages, a principle which demonstrates that the mere infringement of a right is also damage, even if it is not proven in material or financial terms. By the words of Halsbury, LJ:

"a technical phrase which means that you have negative anything like real damage, but that you are affirming by your nominal damages that there is an infraction of a legal right which, though it gives you no right to any real damages at all, yet gives you a right to the verdict or judgment because your legal right has been infringed.' 51

However, beyond this approach found in tort law, English law has introduced damages for violations of rights under the Human Rights Act of 1998. Section 8 of the Human Rights Act provides that the where an act of a public authority is found to be unlawful vis-à-vis the Human Rights Act, the courts may grant compensation where it is necessary to afford just satisfaction. ${ }^{52}$ This, as per the House of Lords in $R$ (Greenfield) v. Secretary of State for the Home Department, ${ }^{53}$ is deemed to be a different system of compensation modelled after the system offered by the European Court of Human Rights rather than domestic tort law. ${ }^{54}$ Indeed Section 8(4) of the Human Rights Act provides that the standards of Article 41 of the ECHR should be

\footnotetext{
51 The Mediana [1900] AC 113, 116 (HL).

52 Section 8(3) of the Human Rights Act.

53 [2005] UKHL 14; [2005] 1 W.L.R. 673.

54 This approach was also followed by the UK's Court of Appeal in Van Colle v. Chief Constable of the Hertfordshire Police [2007] EWCA Civ 325; [2007] 1 W.L.R. 1821.
} 
used in determining the necessity for the awarding of damages, as developments in English law should mirror the developments in Strasbourg. ${ }^{55}$

French law allows the so-called franc or euro symbolique; the decision of the court rectifies the suffered harm where that cannot be quantified, for example the violation of an intangible property right. ${ }^{56}$ In Ireland, the Supreme Court has ruled that constitutional rights may be invoked horizontally and damages are awarded for the violation of a constitutional right where there is an absence of a tort law or statutory cause of action. ${ }^{57}$

In Cyprus, the question of whether the violation of a constitutional right may be an autonomous cause of action was raised before the Supreme Court. ${ }^{58}$ The Supreme Court based its reasoning on Article 35 of the Constitution which requires judicial authorities to ensure the effective protection of the rights contained in the Constitution and stated:

"The matter of compensation for the violations of human rights per se, without these constituting torts, is not covered directly by any previous judgment of the Supreme Court. The universal character of the fundamental rights of the human, their significance for its existence and their substantive protection by the Constitution, tends to delineate the parameters for determining the matter of compensation. The effective application of human rights, as outlined by Article 35 of the Constitution, requires the awarding of compensation to the victim for any damage caused to its entity, as a natural and social being" 59

\footnotetext{
${ }^{55}$ J. Steele, 'Damages in tort and under the Human Rights Act: remedial or functional separation?' (2008) CLJ 606, 610-611,

56 Crim. 16 May 1974, D. 1974, 513; Civ 26 September 1984, JCP 1984 IV 327.

57 Meskell v CIE [1973] I.R. 121, Hanrahan v Merck Sharp and Dohme (Ireland) Ltd [1988] IESC 1, and McDonnell v Ireland [1998] 1 I.R. 134, see also Kane J., 'Civil liability for exploiting trafficking victims? A speculative application of Meskell v Cie?' (2015) Irish Jurist 57.

58 Takis Yiallouros v. Eugenios Nicolaou (2001) 1 CLR 558. The precedent set by the Supreme Court in this case was also followed in Republic via the Advocate General v. Argyris Georgiou (2003) 1 CLR 704, where a civil action for compensation against the state for the violation of the rights to equality, fair trial and an effective remedy, was deemed to disclose prima facie a good cause of action.

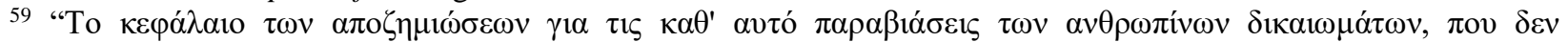

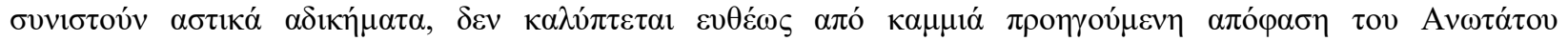

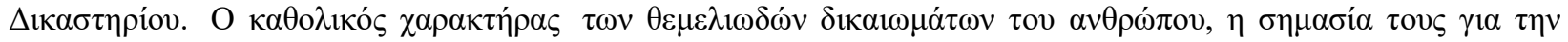

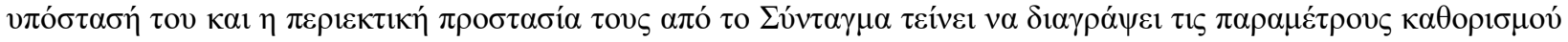

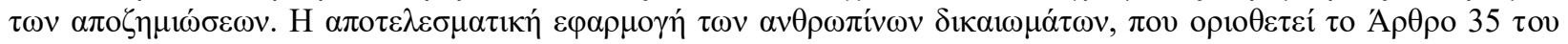


In this case the Supreme Court awarded 'general damages' whereby the claimant requests damages for the violation of a right, leaving however the judiciary to decide on the amount of compensation that is suitable for the violation found.

The existence of the above national law approaches to compensation for the violation of a human right per se demonstrates that human rights are of paramount importance in national law and therefore that all individuals must have the opportunity of being compensated in a substantive way for the violation of their rights. Secondly, it is evident that compensating human rights violations per se without specific damage being proven is a principle common to several Member States and that must be taken into account by the CJEU. Furthermore, the fact that such procedures are independent of other causes of action may also serve as an inspiration for the CJEU to develop different rules when it comes to damages actions relating to human rights.

These systems, as opposed to the rationale of the CJEU regarding the award of damages, give some satisfaction by delivering a judgment which satisfies the victim of the infraction and vindicates her right. The CJEU on the other hand, deprives this possible satisfaction by precluding any judgment in favour of a victim unless the damage is proven by concrete elements, with the only alternative of remedying the violation of the contested right, being the administrative law procedure under Article 263 TFEU for the annulment of the act. ${ }^{60}$

\section{The European Court of Human Rights}

Another, more topical comparison may be drawn in the context of the protection of human rights in Europe with the approach taken by the European Court of Human Rights. Article 41 of the Convention provides that the ECtHR may afford just satisfaction to the injured party should domestic law allow only a partial reparation. The award for just satisfaction has four criteria that were formulated in the Vagrancy cases. ${ }^{61}$ Firstly, there must exist a decision of the ECtHR that a national measure of a contracting state is in conflict with its obligations under the Conventions; that the consequences of the violation are only capable of being eradicated partially at the

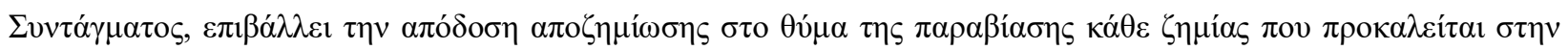

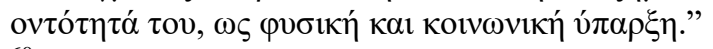

${ }^{60}$ See cf. Roquette (n.38) and cf. Zavvos (n.22).

${ }^{61}$ De Wilde, Ooms and Versyp v. Belgium (just satisfaction) (App. no. 2832/66; 2835/66; 2899/66) ECtHR 10 March 1972, [1972] ECHR 1 Series A no. 14. 
national level; the existence of an injured party; and the estimation by the ECtHR that just satisfaction is necessary. The first two requirements are in essence admissibility requirements and the other two are the conditions for the compensation to be granted. ${ }^{62}$

This provision has a similar role as the principle of non-contractual liability in EU law, as its main subject matter is the remedies available to the injured parties. The ECtHR's approach is surprisingly similar to the one found in the ECJ case law of non-contractual liability: it only awards damages for losses that are proven to have been caused by the violation. In Kingsley ${ }^{63}$ the ECtHR stated:

"The Court will award financial compensation under Article 41 only where it is satisfied that the loss or damage complained of was actually caused by the violation it has found (see the authorities cited in paragraph 43 below), since the State cannot be required to pay damages in respect of losses for which it is not responsible."

Therefore, the issue of proven damage and causal link between the unlawful behaviour is apparent in that legal system as well. It has been observed that the ECtHR does not award damages for non-pecuniary loss easily when the finding of a human rights violation and the legislative change which will be brought is expected to benefit the applicant - the finding of violation may be regarded as just satisfaction. ${ }^{64}$

Just satisfaction may be offered as a form of compensation for moral harm ${ }^{65}$ as well as material ${ }^{66}$ and pecuniary harm. ${ }^{67}$ For such an award, the applicants must establish a direct causal link between the breach and the alleged damage. ${ }^{68}$ For material harm, compensation may be granted for damnum emergens, which needs to be proven by submitting an expert report, which will

\footnotetext{
${ }^{62}$ Enrich Mas E., 'Right to Compensation under Article 50' in Mcdonald J, Matscher F and Petzold H (eds) The European System for the Protection of Human Rights (Dodtrecht: Martinus Nijhoff 1993), 779-84. Kingsley v. The United Kingdom (App No. 35605/97) ECtHR 28 May 2002 [GC] (2002) 35 EHRR 17763.

${ }^{64}$ Foster S., 'Case Comment Prisoners' rights - right to vote - European Court of Human Rights - just satisfaction' [2014] Coventry Law Journal, 78-81.

${ }^{65}$ Halford v. the United Kingdom, 25 June 1997, Reports of Judgments and Decisions 1997-III para 76.

${ }^{66}$ Kadikis v. Latvia (no.2) (App. No. 62393/00) ECtHR 4 May 2006, paragraph 67.

${ }^{67}$ Barbera, Messegué and Jabardo v. Spain (Application no. 10588/1983) (Article 50) ECtHR 13 June 1993, Series A no. 285-C Çakici v. Turkey (App No. 23657/94) ECtHR 8 July 1999 [GC] ECHR 1999-IV, Salman v. Turkey [GC] no. 21986/93 ECHR 2000-VII, Ertak v. Turkey (App no. 20764/92) ECtHR 9 May 2000, ECHR 2000-V.

${ }^{68}$ Matthew v. the Netherlands (App. No. 24919/03) ECtHR 29 September 2005, paragraphs 223-4.
} 
substantiate the claim for the loss sustained. ${ }^{69}$ The same applies where the claim regards lucrum cessans, that being the loss of a profit. ${ }^{70}$

Non-pecuniary or moral harm has been admitted to be reparable under the just satisfaction procedure since Ringeisen ${ }^{71}$ in 1972. Ichim argues that where the matter regards non-pecuniary harm, causation is evident to the point that the Court does not need to make an assessment in order to make the award, since moral suffering is inherent in every violation of a human right. ${ }^{72}$ Nevertheless where the victim claims a specific manifestation of the moral harm, a link of causation must be proven. ${ }^{73}$ That must be a link related to the specific violation that has been found to exist during the judgment on the merits. For example, in the Vagrancy cases ${ }^{74}$ the applicant's claim for just satisfaction failed because there was not sufficient link between the violation of Article 5(4) of the Convention and the damage they claimed; the applicants claimed that the moral damage they suffered was the deprivation of their liberty, while the violation found was the absence of a remedy to challenge the lawfulness of their detention.

There is a substantial difference between the procedures before the CJEU and the ECtHR. As opposed to the CJEU in the context of the action for damages, the ECtHR examines the matter of the violation and the damage separately, with two separate judgments. ${ }^{75}$ A judgment on just satisfaction presupposes a success in the procedural limb regarding the merits of the case. Therefore, before the ECtHR an applicant may be successful in obtaining a favourable decision on the merits, without just satisfaction, which is in itself a substantial remedy.

The ECtHR has stated that its judgments are primarily declaratory, and that the main objective is that the state violating the human right rectifies the breach through its repeal or a legislative

${ }^{69}$ Maria Violeta Lăzărescu v. Romania (Application no. 10636/06) ECtHR 23 February 2010 [2010] ECHR 237.

${ }^{70}$ Jersild v. Denmark (App. No. 15890/89) ECtHR 20 October 1994, (1994) 19 EHRR 1, Özturk v. Turkey (App. No. 22479/93) 23 September 2009 [GC] ECHR 1999-VI, Wizerkaniuk v. Poland, (App. No 18990/05) ECtHR 5 July 2011, Lahtonen v. Finland (App. No. 29576/09) ECtHR 17 January 2012 [2012] ECHR 44.

${ }^{71}$ Ringeisen v. Austria, (Article 50) (App. No. 2614/65) ECtHR 22 June 1972 1972] ECHR 2.

${ }^{72}$ Ichim O., Just Satisfaction under the European Convention on Human Rights (CUP 2015) 22.

${ }^{73}$ Ibid, 26.

${ }^{74}$ cf. De Wilde, Ooms and Versyp v. Belgium (n.61).

${ }^{75}$ The judgments on the merits and the just satisfaction may be delivered at the same time or with a time difference, according to whether the Court is ready to deliver a judgment on just satisfaction or reserve it or require further observations from the parties. The decisive factor is the complexity of the dispute. The procedural rule is Rule 60 of the Rules of Procedure of the ECtHR. See also cf. Ichim (n.72) 176-177. 
change, which is supervised by the Committee of Ministers, which is in fact a substantial remedy. In Verein gegen Tierfabriken Schweiz ${ }^{76}$ the ECtHR pointed out that

"61. The Court reiterates that findings of a violation in its judgments are essentially declaratory (see Marckx v. Belgium, 13 June 1979, § 58, Series A no. 31 ; Lyons and Others v. the United Kingdom (dec.), no. 15227/03, ECHR2003-IX ; and Krčmář and Others v. the Czech Republic (dec.), no. 69190/01, 30 March 2004 ) and that, by art.46 of the Convention, the High Contracting Parties undertook to abide by the final judgments of the Court in any case to which they were parties, execution being supervised by the Committee of Ministers (see, mutatis mutandis, Papamichalopoulos and Others v. Greece (art.50), 31 October 1995, § 34, Series A no. 330-B ).

In the case of Firth, ${ }^{77}$ the ECtHR denied compensation for non-pecuniary damage even if it found the ban on prisoner's right to vote contrary to Article 3 of Protocol 1. In this case, the Court referred to $\mathrm{Hirst}^{78}$ which ruled on the same subject matter that:

'it will be for the United Kingdom Government in due course to implement such measures as it considers appropriate to fulfil its obligations to secure the right to vote in compliance with the judgment, and that in the circumstances this may be regarded as providing the applicant with just satisfaction for the breach in this case ${ }^{79}$

The concept of legal satisfaction provided by a declaration or acknowledgment of the breach stems from international law. In the Corfu Channel Case, ${ }^{80}$ the International Court of Justice held that the finding of a violation of international law and the declaration made by the Court should in itself be considered as satisfaction. While nothing in the ECHR refers to declaratory judgments as satisfaction, the Court itself has accepted it as a form of satisfaction. ${ }^{81}$ The court

\footnotetext{
${ }^{76}$ Verein gegen Tierfabriken Schweiz (VGT) v Switzerland (App. No. 32772/02) ECtHR 30 June 2009 [GC] (2011) 52 EHRR 8.

77 Firth and others $v$ United Kingdom (Applications nos. 47784/09, 47806/09, 47812/09, 47818/09, 47829/09, 49001/09, 49007/09, 49018/09, 49033/09 and 49036/09) ECtHR 15 December 2014 (2014) ECHR 874.

${ }^{78}$ Hirst v United Kingdom (No. 2) (Application No. 74025/01) ECtHR 6 October 2005 (2006) 42 EHRR 41.

${ }^{79}$ For further analysis of these judgments see Foster S., 'Prisoners' rights - right to vote - European Court of Human Rights - just satisfaction' Coventry Law Journal 79.

${ }^{80}$ Corfu Channel, Merits ICJ Reports 1949, 35.

${ }^{81}$ Marckx v. Belgium (App. No. 6833/75) ECtHR 13 June 1979 (1979) 2 EHRR 330.
} 
considers its finding of a violation as a form of legal satisfaction for non-pecuniary damage which exists but is minimal, thus not deserving more than judicial recognition. ${ }^{82}$

In addition, what distinguishes Article 340(2) from just satisfaction procedures is that a judgment of the ECtHR declaring a violation generates an automatic obligation for rectification of the breach, that being restitutio in integrum, an element which does not appear in Article 340(2) cases.

The ECtHR from this viewpoint follows general public international law on the matter of restitution. More specifically, in Papamichalopoulos, ${ }^{83}$ the ECtHR made express reference to the decision of the Permanent Court of International Justice in the Factory at Chorzow. ${ }^{84}$ In this case it was held by the PCIJ that reparation must as far as possible, wipe out all the consequences of the illegal act and re-establish the situation which would in all probability have existed if that act had not been committed.

The ECtHR following that, went on to rule in Papamichalopoulos that where the nature of the breach allows for restitutio in integrum it is for the respondent state to effect it. The obligation to establish a situation ex-ante is a direct result of the delivery of a judgment which finds a violation. ${ }^{85}$ The Court may well indicate the measures to be taken in order to rectify the breach. ${ }^{86}$ This is later on supervised by the Committee of Ministers as per Article 46 of the Convention.

In fact, just satisfaction is considered to be a second or back-up option where the restitution envisaged by the judgment itself is proved to be insufficient or partial. Article 41 itself states that just satisfaction is only offered where the internal law of the state allows only partial reparation. That means that the Court must first inquire into what is available at a domestic level to rectify

\footnotetext{
82 cf. Ichim (n.72) 136.

${ }^{83}$ Papamichalopoulos and Others v. Greece (Article 50) (App. No. 14556/89) ECtHR 31 October 1995, Series A no. 330-B, 34 and 36.

${ }^{84}$ Factory at Chorzow (Merits) 1928 PCIJ, Series A, No. 17, at 47.

${ }^{85}$ L. Loucaides, 'Reparation for violations of human rights under the European Convention and restitutio in integrum' (2008) 2 EHRLR 182-192, 189.

${ }^{86}$ Ilaşcu v. Moldova (Application No. 48787/99) ECtHR 8 July 2004 [GC] (2005) 40 EHRR 46.
} 
the violation in order for a claim for just satisfaction to be admissible. ${ }^{87}$ This confirms the subsidiarity of the remedy of just satisfaction to restitutio in integrum. ${ }^{88}$

By analogy, the unlawfulness of an EU act is something that may be remedied, or extinguished per se through the Article 263 procedure for annulment rather than Article 340(2), as an infringement per se does not necessarily cause quantifiable damage. Article 340(2) is not a vehicle for legislative or administrative reform, as it does not annul the relevant act and in an action for damages the courts do not suggest legislative changes as a means of reparation of the damage in question.

What is evident nevertheless, is that the issue of finding a violation of a human right and the damage caused by a violation seem to be distinct issues in both the jurisprudence of the ECtHR and the CJEU. The pure finding of a violation of a fundamental right in EU law can be remedied through the review of legality found in Article 263(4) TFEU.

However, the ECtHR's interpretation of Article 41 of the Convention has broadened over the last years ${ }^{89}$ which may also indicate the same need within the EU law context of Article 340(2). In 2014, the ECtHR awarded a lump sum of $€ 90$ million in the inter-state case of Cyprus $v$. Turkey. ${ }^{90}$ What is the breakthrough from the earlier position of the ECtHR, is that in this case neither the damage could possibly be quantified, nor the number of possible victims. In this particular case, the claim was brought by the Republic of Cyprus on behalf of the relatives of the missing persons of the 1974 invasion and the enclaved residents in the part of the island that is occupied by the Turkish troops. In the case of the relatives it is impossible to know the precise number of possible descendants of the missing persons. This brings forward another question, whether damages in human rights claims may be one of punitive rather than nominal character, ${ }^{91}$ given that in this decision the punitive character of the award was highlighted by two of the judges as well. ${ }^{92}$

\footnotetext{
${ }^{87}$ cf. Ichim (n.72) 67.

88 Ibid.

${ }^{89}$ F. Kollmar and J.M. Hoffman, 'Fewer complaints, more satisfaction: Cyprus v Turkey (Case Comment)' (2014) 3(4) CJICL 1361-1375, 1363.

${ }^{90}$ Cyprus v. Turkey (just satisfaction) (App. No. 25781/94) ECtHR 12 May 2014.

${ }^{91}$ cf. Kollmar and Hoffman, (n.89) 1370.

92 Concurring Opinion of Judge Pinto de Albuquerque, joined by Judge Vučinić) para 13.
} 
The criterion of causation has also been applied in a more inclusive manner, being broadened in comparison to the earliest Vagrancy cases. For example, Sabah El Leil ${ }^{93}$ the Court awarded damages for a loss of opportunity and pecuniary damage that was flowed from a violation of the right to a fair trial. The applicant's employment contract in the Kuwaiti embassy in Paris was terminated and he sustained a violation of his right to access to a court. Prima facie, there is no direct link between the violation of the procedural right to access to a court and loss of opportunity or earnings, yet the Court found that the applicant had suffered a loss of opportunity and non-pecuniary damage.

In the similar case of Cudak v. Lithuania, ${ }^{94}$ the Court awarded the applicant ten thousand euro in the absence of a domestic judgment and also required a retrial. While the recovery of salaries would usually be directly linked to Article 1 of Protocol 1 protecting the right of property, the Court accepted the loss of property pertaining to a violation of a procedural trial right. This essentially means that the ECtHR has awarded compensation for the damage that was the subject matter of the domestic proceedings, creating a precedent for providing itself the compensation that was at stake in the national courts. ${ }^{95}$

\section{F. Conclusion}

Obtaining compensation for the violation of a fundamental right is neither easy nor direct: it requires the fulfilment of multiple requirements, which the courts of the EU construe strictly. Over the years, the CJEU has developed criteria for the satisfaction of a claim for damages that are stricter to those examined by national court in public authority liability cases. As it was analysed in detail above, the 'but for test' is not sufficient in damages actions against the Union. Therefore, although the immediate victim of the human right violation may be able to prove the material or non-material damage, Article 340 does not generally allow indirect claims. Furthermore, moral damage is another aspect of human rights claims that on the basis of the case law is difficult to be proven. ${ }^{96}$ Where the applicant requests compensation for moral, and thus non-quantifiable damage, the applicant must at the very least prove that the conduct in question

\footnotetext{
${ }^{93}$ Sabeh El Leil v. France (App no. 34869/05) ECtHR 29 June 2011 [GC] (2012) 54 EHRR 14.

${ }^{94}$ Cudak v. Lithuania (App. No. 15689/02) ECtHR 23 March 2010 [GC] (2010) 51 EHRR 15.

${ }^{95}$ cf. Ichim (n.72) 29.

${ }^{96}$ cf. SELEX Sistemi Integrati (n.12)
} 
was grave enough to cause that damage. While this in principle allows claims for moral damage which may exist in human rights-related cases, the wording of the CJEU is restrictive, thus limiting the procedure's effectiveness in protecting human rights.

Furthermore, the fact that the CJEU has traditionally taken a restrictive approach as to the nature of damage that may be claimed is also an important limitation in human rights claims where the damage is not always quantifiable or visible. The CJEU does not award nominal damages under the Article 340 procedures - this may be a drawback in the effective protection of fundamental rights given that often the compensation sought after in those cases is the mere recognition of a violation. The CJEU however, will not allow a non-contractual liability claim unless all three requirements of causation, damage and unlawfulness are fulfilled and neither will it issue declaratory judgments in this context. This may limit the role that Article 340 may have as an alternative an action of annulment, of which the criteria are also very stringent.

Nevertheless, the fact that the CJEU has in some cases recognised that the violation may be grave enough so as to require more than the declaration of unlawfulness in order to be compensated, ${ }^{97}$ is a positive development which may gradually shift the understanding of the EU judiciary so as to grant damages for the violation of the right per se. This would constitute the non-contractual liability procedure more effective as a vehicle for human rights claims.

By comparing the approach taken by the ECtHR and also domestic law, to the approach taken by the CJEU in the case law in Section (D) above, it is evident that the CJEU takes a restrictive approach compared to domestic law on awarding compensation for the violation of a right per se, requiring proof of damage in the Article 340 procedure, as opposed to nominal damages, the franc symbolique, and the cause of action for compensation under the Human Rights Act.

The approach taken by the CJEU resembles more the one of the ECtHR which requires proof of damage for just satisfaction, but it must be borne in mind that the ECtHR will have first issued a declaratory judgment of which the aim is to push for internal legal reforms in the respondent

\footnotetext{
${ }^{97}$ Case T-577/2014 Gascogne Sack Deutschland GmbH and Gascogne v European Union Judgment of the General Court (Third Chamber, Extended Composition) of 10 January 2017.ECLI:EU:T:2017:1, Case T-384/11 Safa Nicu Sepahan Co. $v$ Council of the European Union ECLI:EU:T:2014:986.
} 
state, that being a far-reaching effect of the judgment. This is not a feature of the action for damages procedure, where the action will fail in its entirety, even if unlawfulness is found.

The approach taken in English law, whereby any damages may be claimed on the basis of a violation of a human right under the HRA 1998, by public bodies, could be followed by the CJEU - in light of the fact that a violation of a human or fundamental right recognised in Union law by the Union itself, is substantiated in litigation, the CJEU could develop its case law so as to award compensation for that. This would improve and constitute the action for damages procedure a true vehicle of protection of fundamental rights in Union law. Although this has not yet come to be expressly accepted, certain developments in EU case law such as in Safa Nicu Sepahan, ${ }^{98}$ and in Gascogne Sack Deutschland GmbH and Gascogne v European Union ${ }^{99}$ (both discussed in Section D above), reveal an understanding by the EU judiciary that the violation of a right inherently contains moral damage worthy of compensation.

98 Ibid.

99 Ibid. 


\section{Chapter 7}

\section{EU non-contractual liability for lawful acts and rights-based claims}

\section{A. Introduction}

Where an act is judged unlawful and directly causes damage to the applicant a non-contractual liability claim will be successful. Certain legal systems compensate damage caused by a public authority even where the act is not strictly speaking contrary to the law. The present Chapter will explore the possibility of finding liability without the act being necessarily unlawful.

Within the framework of the discussion of non-contractual liability and human rights violations by the EU, this Chapter argues that the discussion for the creation of liability of the Union for lawful acts would not be useful vis-à-vis human rights claims against the EU on the basis of Article 340(2) TFEU.

\section{B. The liability for lawful acts in EU law and human rights}

So far, there has been no express acceptance of the possibility of liability for lawful acts in the EU Courts' jurisprudence. Lawful acts of state organs are not compensated for in all legal systems of Member States.

The possibility of finding liability for lawful acts essentially means that there is the possibility of strict liability for public bodies ${ }^{1}$ (in the case of the EU and EU institutions). This would fill the gap in cases where the wide margin of discretion enjoyed in policy matters renders finding fault liability difficult. ${ }^{2}$ Therefore while a finding of liability for an unlawful act requires the violation of a legal rule by a specific act, liability for lawful acts may serve where the institution's policy has caused damage without any identifiable breach of a legal rule.

The principle of égalité devant les charges publiques, which emanates from French civil law, is the best example of a doctrine which allows for compensation for lawful acts. This principle,

\footnotetext{
${ }^{1}$ C. Van Dam, 'Who's Afraid of Diversity? Cultural Diversity, European Co-Operation, and European Tort Law' (2009) 20 KLJ 281-308, 289.

${ }^{2}$ Ibid.
} 
also found in other civil law systems, such as Dutch and German law, allows private law to intervene in case administrative law cannot offer redress, for example through a finding of unlawfulness. $^{3}$

In these systems, remedies may be sought if the lawful action exceeds the normal social risks and affects the applicant disproportionately more than other individuals. ${ }^{4}$ Engelhard et al give the examples of construction of railways and airports, spatial planning or water management, where the people located near the infrastructure may suffer from noise pollution or cannot enjoy their property, while society in general benefits from such lawful works. ${ }^{5}$ This may therefore limit one's rights to enjoy their property and their private and family life.

As early as 1984 the question of liability for lawful acts permeated the case law of the CJEU. In Biovilac $^{6}$ was held that if the concept of liability without fault were to be accepted in European Union law, the principle that liability requires the existence of damage exceeding the limits of the economic risks inherent in operating in the sector concerned, would have to be applied a fortiori. On a theoretical or hypothetical basis, the CJEU in Dorsch Consult ${ }^{7}$ stated that should the doctrine of liability for lawful acts come to be accepted in EU law, the criteria would be whether the applicant has suffered a subsisting damage which affects a circle of economic operators disproportionately compared to others, exceeding the economic risks inherent in the relevant sector and the lawful measure is not justified by a general economic interest.

\footnotetext{
${ }^{3}$ E. Engelhard, B. van den Broek, F. de Jong, A. Keirse, E. de Kezel, 'Let's Think Twice before We Revise! 'Egalité' as the Foundation of Liability for Lawful Public Sector Acts', (2014) 8 Utrecht L Rev 55-88, 56.

${ }^{4}$ Administrative Jurisdiction Division of the Council of State (Afdeling bestuursrechtsproak van de Road van State, ABRS) 18 February 1997, AB 1997/143, note PvB (Beurskens) and Dutch Supreme Court (Hoge Road der Nederlanden, HR) 30 March 2001, NJ 2003/615, AB 2001/412 (the State v. Lavrijsen). In ABRS 6 May 1997, AB 1997/229 (Van Vlodrop), the Dutch ABRS recognised a right to compensation in cases of lawfully caused damage that'reasonably should not be borne by the individual who suffered the damage'. This is usually interpreted as 'disproportionate damage, exceeding the normal social risk, as referred to in the egalite principle'. In Germany it is considered that all state action should be capable of being challenged in Court, See W. Ritfnner, 'Basic Elements of German Law on State Liabiity in John Belland Anthony W Bradley (eds), Governmental Liability: A Comparative Study (UKNCCL, 1991) 252.

${ }^{5}$ cf. Engelhard et al (n.3), 58.

${ }^{6}$ Case 59/83, SA Biovilac NV [1984] ECR 4057, Para. 28.

${ }^{7}$ Case T-184/95 Dorsch Consult Ingenieurgesellschaft mbH v. Council and Commission [1998] ECR II-667, upheld in Case C-237/98 P [2000] ECR I- 4564.
} 
In $F I A M M{ }^{8}$ the Court of First Instance attempted to make a breakthrough by stating that as EU law is based on the general principles common to the laws of the Member States, and as the Member States legal systems recognise liability for lawful acts, it should also apply at a Union level. ${ }^{9}$ According to the CFI, a decisive criterion for the existence of non-contractual liability is the unusual or special damage suffered by the applicant. ${ }^{10}$ Consequently, where there occurs an unusual and special damage suffered by the applicant directly linked to the Union's action, then according to this formula, non-contractual liability would arise.

This case regarded the Regulation (EEC) No 404/93 on the common organisation of the market in bananas. This Regulation was deemed as incompatible with WTO law by the WTO Dispute Settlement Body. ${ }^{11}$ The EU passed no sufficient legislative acts to remedy this incompatibility and there was no agreement on compensation for the incompatibility and by consequence, WTO members were allowed to suspend concessions and other obligations to the EU (then the European Communities). ${ }^{12}$

Such retaliatory measures taken by the USA affected the applicants who exported batteries. The applicants therefore brought a claim for non-contractual liability of the Union. They claimed the measures caused a $96.5 \%$ increase in the import duty levied by the United States authorities on the applicants' imports of batteries into the United States. They claimed the costs incurred in respect of the setting up and the relocation of production units for those products which they were compelled to undertake in response to that trade retaliation measure. The applicants also claimed losses of turnover resulting from the reconversion of the production units in question.

The Court of First Instance, followed the test it formulated about non-contractual liability for lawful acts and rejected the claim on the basis that the applicants had not proven that the damage

${ }^{8}$ Case T-69/00 FIAMM v. Council and Commission [2005] ECR II-4549.

9 Ibid, paras 151-153.

${ }^{10}$ Ibid, para 160.

11 See for an overview of the Bananas and Hormones cases http://www.wto.org/english/tratop_e/dispu_e/cases_e/ds26_e.htm,http://www.wto.org/english/tratop_e/dispu_e/case s_e/ds48_e.htm and http://www.wto.org/english/tratop_e/dispu_e/cases_e/ds27_e.htm

${ }^{12}$ For detailed analysis see Thies A., 'The impact of general principles of EC law on its liability regime towards retaliation victims after FIAMM' (2009) ELR 889. 
they claimed exceeded the normal risk inherent in their export activities. ${ }^{13}$ This judgment was appealed against by the applicants.

During the appeal, Advocate General Poiares Maduro strongly argued in his Opinion in FIAMM ${ }^{14}$ that the principle of liability for lawful acts as found in the laws of the Member States should be incorporated in EU law. More specifically he stated:

"Establishing a principle of no-fault Community liability would make it possible, in the interests of justice, to offset the severity of the conditions for the incurring of fault-based Community liability, linked in particular to the need for a sufficiently serious breach of a rule of law protecting individuals, in order to give the victims of particularly serious damage suffered as a result of the conduct of the Community institutions the possibility of obtaining compensation. The appropriateness of such a solution no doubt explains why the Court has never ruled out the possibility of enshrining it in Community law. Moreover, although this legal solution is to be found only in some national legal systems, the concern it expresses and the protection it provides for legal interests are also taken into account in other legal systems, even if, as we shall see, different legal mechanisms are employed."

AG Poiares-Maduro's point of view was that the incorporation of such a principle in EU law would be in favour of good governance and that it made up for situations where the applicants could not possibly be successful in an annulment action, a preliminary ruling or in a damages action where they could not establish unlawfulness. The particular dispute in FIAMM related to the compatibility of EU action with WTO rules. AG Poiares Maduro made express reference to the corresponding French and German doctrines whereby public authorities must compensate for damage caused by them to an individual when the latter has been more severely affected by a measure than others. ${ }^{15}$

\footnotetext{
${ }^{13}$ Case T-69/00 FIAMM v. Council and Commission [2005] ECR II-4549, § 203.

14 Opinion of Advocate General Poiares Maduro before the ECJ 9 September 2008, Joined Cases C 120/06 and C121/06 FIAMM and Others v. Council and Commission [2008] ECR I-06513, §§ 56-61.

15 Ibid $\$ \$ 62-63$.
} 
In the judgment upon appeal ${ }^{16}$, the CJEU dismissed the appeals of the applicants, but took a different approach on the matter of non-contractual liability for lawful acts, by underlining that it was clear that this principle is not part of EU law. However, it also stated the following:

"184 It follows that a Community legislative measure whose application leads to restrictions of the right to property and the freedom to pursue a trade or profession that impair the very substance of those rights in a disproportionate and intolerable manner, perhaps precisely because no provision has been made for compensation calculated to avoid or remedy that impairment, could give rise to non-contractual liability on the part of the Community."

At the time of this decision, fundamental rights formed part of the general principles and this "obiter dictum" has been characterised as an important development for the application of the general principles in trade cases and the judicial protection of private entities and individuals. ${ }^{17}$ Nevertheless, the Court was still criticised for not going a step further. The fact that the noncontractual liability principle only applies to formally illegal acts rather than substantially illegal acts, is a problem. A solution such as creating a simple fault regime, ${ }^{18}$ could potentially ensure more concretely the right to effective judicial protection.

Despite the diverging opinions, this point in the judgment is indeed significant in order to demonstrate the relationship of human or fundamental rights with the action for damages. First, it is an express recognition that the violation of the right to property and the freedom to pursue a trade right may indeed be a ground for a damages action. Secondly, it raises the question of whether the violation of a right is an exception to the general requirements in an action for damages and becomes in itself a free-standing cause of action for damages, of which the existence will surpass the usual requirement of unlawfulness.

\footnotetext{
${ }^{16}$ Joined Cases C 120/06 and C121/06 FIAMM and Others v. Council and Commission [2008] ECR I-06513.

${ }^{17}$ M. Dani, 'Remedying European legal pluralism: the FIAMM and Fedon litigation and the judicial protection of international trade bystanders (Case Comment)' (2010) 21(2) EJIL 303-340, A. Thies, 'The impact of general principles of EC law on its liability regime towards retaliation victims after FIAMM' (2009) 34(6) ELR 889-913.

${ }_{18}$ P. Pecho, van A. Waeyenberge "Another victim of the "banana war": Some reflections on the status of the principle of liability in the absence of unlawful conduct in the community legal system' (2010) (Serial No.62) USChina Law Review No.1, 7.
} 
The Court in FIAMM $^{19}$ only mentioned two rights: property and the freedom to pursue a trade or profession, and also talked of the issue of proportionality. It is possible to infer from the above that the Court has indirectly recognised the possibility of non-contractual liability for lawful acts in those specific cases. ${ }^{20}$ It has also been claimed that the Court implied that questions of the infringement of fundamental rights by legislative action should be determined under the normal fault liability regime. ${ }^{21}$

\section{Is the exception in FIAMM useful for rights-based cases?}

The discussion of the FIAMM litigation above reveals that the Union's judiciary came for the first time across the question of whether the protection of fundamental rights could be a reason for which lawful acts may still trigger Union liability. This subsection will analyse to what extent the FIAMM litigation has made any contribution in the protection of fundamental rights via the non-contractual liability procedure.

In terms of the decision of the Court of First Instance, if that general rule were accepted, one could argue that human rights violations could be seen as special or unusual damage. Nevertheless, beyond the positive effect that this could possibly have on the protection of human rights in the Union - it could also open floodgates. This could make all Union conduct liable to be reviewed for compensation, ${ }^{22}$ which would be onerous. Nevertheless, the ability to file claims against any Union conduct for compensation vis-à-vis human rights claims would be consistent with the general principles of the Member States and it would fill the gap of having a true and effective cause of action for human rights violations by Union acts.

Where the matter at stake is the violation of a right, it is questionable whether the potential "exception" that was implied by the CJEU here is really an exception for lawful acts. In paragraph 179 of the FIAMM judgment, the CJEU stated that fundamental rights are an integral

\footnotetext{
${ }^{19}$ Ibid.

${ }^{20}$ G. Gattinara, 'WTO in Luxembourg: Inconsistencies and Perpsectives', (2008) Italian Yearbook of International Law 117-136, 121, and also K. Gutman, 'The Evolution of the Action for Damages against the European Union and its Place in the System of Judicial Protection' (2011) 48 CMLRev 743-744.

21 S. Thomas, 'Community Liability for Lawful Conduct: An Aborted Child? Some Comments on the FIAMM Judgment of the ECJ' (13 November 2009). Available at SSRN.

22 K. Arend, 'EC Liability in the Absence of Unlawfulness, The FIAMM Case' (2009) 1 Gottingen Journal of International Law 199-218, 200.
} 
part of the general principles of law. Therefore, finding a violation of a right is, in effect, equated to a finding of unlawfulness. Therefore, the distinction made between lawfulness and unlawfulness is not necessarily clear. The CJEU, in paragraph 184 of the judgment points out that the exception is needed for cases where the lawful measure restricts fundamental rights, but there is no other express deliberation providing for that unlawfulness.

However, fundamental rights also form part of EU constitutional law fabric today, therefore the exception may not be necessary in the first place, as their disproportionate restriction constitutes unlawful conduct, which would satisfy the first criterion for non-contractual liability. The two fundamental rights mentioned in the 'exception' provided for in FIAMM, along with many others, form part of the EU's primary law as part of the Charter and the TFEU. Establishing breach of the principle of proportionality is in reality a finding of unlawfulness given that these rights form part of legal rules, in the EU's case law and legislation.

\section{Conclusion}

It is difficult to place the Court's proposed exception in FIAMM in modern day EU law. The Court in FIAMM introduces these rights as something inherent in every legal or natural person regardless of any legal rules, which is a valid observation. However, given the post-Lisbon dimension of rights in EU law, these rights are not only inherent but indeed expressly recognised and create binding obligations upon EU institutions.

This comes at odds with the distinction between liability for lawful and unlawful acts. Liability for unlawful acts depends on the finding of a violation of a rule conferring rights to individuals. On the other hand liability for lawful acts as it is interpreted in national legal systems, ${ }^{23}$ does not depend on finding the violation of a legal rule but rather identifying a lawful activity which causes disproportional burden on the persons concerned, ${ }^{24}$ therefore facilitating finding liability for activity where the relevant respondent enjoys policy discretion. ${ }^{25}$ Consequently in FIAMM

\footnotetext{
${ }^{23}$ In ABRS 6 May 1997, AB 1997/229 (Van Vlodrop), the Dutch ABRS recognised a right to compensation in cases of lawfully caused damage that reasonably should not be borne by the individual who suffered the damage' and see also analysis in C. van Dam, European Tort Law (2013).

${ }^{24}$ cf. Engelhard et al (n.3), 58.

${ }^{25}$ C. Van Dam, 'Who's Afraid of Diversity? Cultural Diversity, European Co-Operation, and European Tort Law' (2009) 20 KLJ 281- 308, 289.
} 
the CJEU creates the illusion that there could potentially be an exception where lawful acts could establish liability. Nevertheless, in that "exception" the violation of a legal rule conferring rights is necessary for the liability for lawful acts. The Court therefore remains faithful to the application of non-contractual liability arising from unlawful acts and does not change, in any substantive way, its interpretation of non-contractual liability rules.

Nevertheless, this opens up a new perspective: the bindingness of human rights on the EU's institutions is even more important because it will allow applicants who, as in FIAMM or Dorsch would invoke the difficult claim of liability for lawful acts when they would be unable to identify a legal rule that binds EU institutions, to bring forward a rights-based claim of unlawfulness.

The disproportional restriction of a right can now be seen as unlawfulness since the EU's institutions are bound by fundamental rights obligations. It is possible that the Court's proposed exception in FIAMM is not even necessary to be developed today. The new dimension of rights in EU law partially makes up for this gap. This would be even more so should the EU also accede to the ECHR, which would establish the international human rights responsibility of the EU in a concrete manner, yet as it has already been discussed, this deficit remains. 


\section{Chapter 8}

\section{The scope of application of the principle of non-contractual liability and human rights}

\section{A. Introduction}

The CJEU has ruled that all claims against the Union for non-contractual liability fall under the exclusive jurisdiction of the Court of Justice. ${ }^{1}$ In Hassens ${ }^{2}$ the Court held that such matters cannot be brought before national Courts. However, this jurisdiction is not all-encompassing. Not all types of acts or Union bodies can fall under the Court's jurisdiction, given that certain EU bodies, institutions or agencies are not subject to the CJEU's jurisdiction and by extent their acts cannot be challenged before the Courts for non-contractual liability. This limits the possibility for the Union's Courts to offer redress for the violation of human rights by these bodies, institutions or agencies. Consequently, the objective of this Chapter is to examine how broad is the CJEU's jurisdiction over acts and bodies of the Union for non-contractual liability and in light of that, whether the scope of application of the principle of non-contractual liability is sufficient for the protection of human rights.

To this end, Section (B) will examine which acts may be contested for engaging the Union's non-contractual liability, Section (C) will explore what is the scope of the application of the principle in relation to the different actors within the EU, Section (D) will examine in what competence areas the principle applies and how this scope interacts with human rights protection and Section (E) will conclude with some observations on the effect of this scope of application on the protection of rights within the Union.

\section{B. Type of Acts Covered by Non-Contractual Liability and Human Rights}

The material scope of Article 340 covers not only legislative and administrative acts which originate from Union institutions, but also the liability of the Union which may be triggered by more traditional civil causes of action and factual acts, such as accidents of employees. ${ }^{3}$ The only

\footnotetext{
${ }^{1}$ Case C-377/09 Hanssens-Ensch v European Community [2011] 1 CMLR 13.

2 Ibid.

3 Cases 169/83 and 136/84 Gerhardus Leussink and others v Commission of the European Communities. Officials [1986] ECR 1986-02801.
} 
distinction which has been made as to the application of Article 340 is whether the challenged act is discretionary or not. ${ }^{4}$ The nature of the measure, whether it is legislative, administrative, general or individual has not made a difference as to how Article 340 is applied. $^{5}$

More recently, in Groupe Gascogne, ${ }^{6}$ the CJEU expressly admitted that judicial action, which can violate fair trial rights, is also subject to a non-contractual liability claim. In this case the applicant had claimed, in their appeal from the GCEU to the CJEU that the lengthy proceedings in the GCEU violated the right to a fair trial as it is guaranteed by Article 47 of the Charter. The CJEU recognised that

"83 It is therefore appropriate for the Court of Justice to rule that the sanction for a breach, by a Court of the European Union, of its obligation under the second paragraph of art.47 of the Charter to adjudicate on the cases before it within a reasonable time must be an action for damages brought before the General Court, since such an action constitutes an effective remedy."

Nevertheless, the CJEU also stated in this case that a fair trial-related claim for damages is not to be determined by an appeal on the substance of the dispute. It is a separate cause of action in Union law and as such must be ascertained in a separate procedure. ${ }^{7}$

This general breadth of the range of activities that can be subject to an action for damages may be a factor that constitutes this procedure a more fruitful one for the protection of rights in comparison to the stricter criteria set in the procedure for annulment of an act (see for more detail Chapter 2 of Part I). A good example would be the comparing and contrasting the decisions of the CJEU in Konstantinos Mallis $^{8}$ and Ledra Advertising. ${ }^{9}$

\footnotetext{
${ }^{4}$ S.L. Kaleda, 'Claims for damages in EU procurement and effective protection of individual rights' (2014) 39(2) ELR 193-209, 205.

${ }^{5}$ Case C-472/00 P Commission v. Fresh Marine A/S [2003] ECR I-7541, para 27, and more recently Arcelor cf. (n13).

${ }^{6}$ Case C-58/12 P Groupe Gascogne SA v European Commission [2014] 4 CMLR

${ }^{7}$ Ibid, paragraph 91.

${ }^{8}$ Joined Cases C-105/15 P to C-109/15 P Konstantinos Mallis and Others v European Commission and European Central Bank (ECB) Judgment of the Court (Grand Chamber) of 20 September 2016 ECLI identifier: ECLI:EU:C:2016:702.

${ }^{9}$ Joined Cases C-8/15 P to C-10/15 P Ledra Advertising Ltd and Others v European Commission and European Central Bank (ECB) Judgment of the Court (Grand Chamber) of 20 September 2016 ECLI:EU:C:2016:701.
} 
Both cases involved the same subject: the adoption of a Memorandum of Understanding between the European Stability Mechanism, in which the Commission and the ECB participated, for a direct levy from private bank accounts to secure economic stability. In Mallis the applicants claimed that the Commission's and the ECB's actions were an infringement of Article 263 TFEU. The Court Stated the following:

"53 In addition, it must be pointed out that the role of the Commission and the ECB as defined by Article 1 of Protocol No 14 on the Eurogroup cannot be wider than the role accorded to those institutions by the ESM Treaty. As noted by the General Court in paragraph 48 of the orders under appeal, it is apparent from paragraph 161 of the judgment of 27 November 2012, Pringle (C-370/12, EU:C:2012:756), that, whilst the ESM Treaty entrusts to the Commission and the ECB certain tasks relating to the attainment of the objectives of that Treaty, first, the duties conferred on the Commission and ECB within the ESM Treaty do not entail the exercise of any power to make decisions of their own and, secondly, the activities pursued by those two institutions within the ESM Treaty commit the ESM alone.”

In Ledra Advertising, ${ }^{10}$ which concerned the same activity of the Commission and the ECB within the framework of the ESM Treaty, the applicants brought both an action for annulment and for damages for the violation of the right to property. The CJEU took the same stance as to its power to annul the $\mathrm{MoU}$, but distinguished its jurisdiction over the two institutions' activities as part of the damages procedure:

"53 As the Court pointed out in paragraph 161 of the judgment of 27 November 2012, Pringle (C-370/12, EU:C:2012:756), the duties conferred on the Commission and the ECB within the ESM Treaty, important as they are, do not entail any power to make decisions of their own. Furthermore, the activities pursued by those two institutions within the ESM Treaty commit the ESM alone.

${ }^{10}$ Ibid. 
55 However, whilst such a finding is liable to have an effect in relation to the conditions governing the admissibility of an action for annulment that may be brought on the basis of Article 263 TFEU, it cannot prevent unlawful conduct linked, as the case may be, to the adoption of a memorandum of understanding on behalf of the ESM from being raised against the Commission and the ECB in an action for compensation under Article 268 TFEU and the second and third paragraphs of Article 340 TFEU.

59 Consequently, the Commission, as it itself acknowledged in reply to a question asked at the hearing, retains, within the framework of the ESM Treaty, its role of guardian of the Treaties as resulting from Article 17(1) TEU, so that it should refrain from signing a memorandum of understanding whose consistency with EU law it doubts.

60 It follows that the General Court erred in law in the interpretation and application of Article 268 TFEU and the second and third paragraphs of Article 340 TFEU by holding, in paragraphs 46 and 47 of the orders under appeal, on the basis merely of the finding that the adoption of the disputed paragraphs could not formally be imputed to the Commission or the ECB, that it did not have jurisdiction to consider an action for compensation based on the illegality of those paragraphs."

The CJEU therefore found that within the damages procedure, the liability of EU institutions may be triggered by acts within the framework of the ESM. The CJEU however found that there was no unlawfulness as the relevant decisions were justified by the general economic interests of the community which could be compromised if the banking sector in Cyprus collapsed. This is indeed an important deliberation which demonstrates the greater flexibility that the damages action has in relation to the annulment procedure. While this constitutes the damages action more approachable to private individuals for a variety of EU activities, it should always be borne in mind that the Court has a broad discretion to assess the alleged rights violations, as in this case where no violation of the right to property was found in favour of the protection of the economy.

\section{Institutions, bodies, agencies and organs subject to the principle and the protection of human rights}


Article 340, as opposed to Article 263, does not clarify which are the institutions whose acts may be challenged, apart from a direct reference to the European Central Bank, thus making it clear that non-contractual claims should be brought against the ECB specifically. ${ }^{11}$ While Article 263 refers also to 'bodies and agencies' of the Union, Article 340 does not do that - allowing any act of the Union's servants during the performance of their duties to engage the Union's noncontractual liability.

Nevertheless, it has been noted that agencies are vested with powers to take legally binding decisions intended to produce legal effects in relation to third parties. ${ }^{12}$ Therefore, an action stemming from an agency's or a body's action should be directed against that body or agency rather than the Union as a whole. The wording of Article 340 entails the possibility of taking action against bodies and agencies independently of the institutions. ${ }^{13}$

In Sogelma ${ }^{14}$ the General Court stated that as a general rule, actions must be directed against the body enacting the contested measure. This case involved a decision to cancel a tender procedure by the European Agency for Reconstruction. In this specific decision, the General Court made express reference to the issue of the decision-making process:

"51. In the present case, it is the EAR which took the decision to cancel the tender procedure, by virtue of the powers delegated by the Commission in accordance with Regulation No 2667/2000. The Commission played no part in the decision-making process. Accordingly, it is clear that the EAR is the body which enacted the contested measure. Consequently, the applicant may institute proceedings before the Court of First Instance against the EAR in that capacity."

The issue of non-contractual liability of Union agencies is indeed important and due to the lack of express reference to bodies or agencies in Article 340, EU law should be read in a holistic

\footnotetext{
${ }^{11}$ K. Lenaerts, I. Maselis, K. Gutman and J.T. Nowak, EU Procedural Law (OUP 2014) 481

12 Advocate General's Opinion in Case C-270/12 United Kingdom of Great Britain and Northern Ireland $v$ European Parliament and Council of the European Union (Re delegation of powers to ESMA) (Spain, France, Italy and European Commission, intervening) [2014] 2 CMLR 44.

${ }^{13}$ Case 5/71 Aktien -Zuckerfabrik Schöppenstedt v. Council [1971] ECR 975 and also Case T-209/00 Lamberts v Ombudsman [2002] ECR II-2203

14 Case T- 411/06Sogelma [2008] E.C.R. II-277
} 
manner in this area. It must be borne in mind that there may be specific legislative provisions providing for damages claims against specific agencies. ${ }^{15}$

In respect of human rights, an important example is the FRONTEX Regulation. ${ }^{16}$ FRONTEX is the specialized Agency of the EU which has the task of law enforcement in the Union's external borders. ${ }^{17}$ The Regulation contains in its Article 19(3) a provision which repeats the wording of Article 340 - the Agency should make good any damage caused by it or by its servants in the performance of their duties, on the basis of principles common to Member States. Article 19(4) confers the jurisdiction of such disputes to the Court of Justice of the EU. This specific provision is very topical, as the EU is taking a more active role in the policing of the external borders and the numbers of people penetrating the EU from third countries are rapidly increasing, there is also a foreseeable increased risk of human rights violations. As per Article 340(2) any acts of the FRONTEX staff may be considered as an act of a servant of the Union during the performance of their duties.

Similarly, other Agencies of which the activities may have impact on human rights are subjected to the equivalent provisions. ${ }^{18}$ For example, the Union's Agency for operational management of large-scale IT systems is subject to an identical clause, ${ }^{19}$ while it is also under the Data Protection Regulation ${ }^{20}$, due to the fact that it accumulates sensitive information which may result in privacy dispute.

Another important example is the European Police Office, better known as Europol, which was not under the jurisdiction of the CJEU until 2016. The Europol was made an EU agency through a Council decision in $2009 .{ }^{21}$ Article 53 of this Decision, establishes the liability of Europol for non-contractual activities and also allows injured parties to demand the ceasing of the challenged

\footnotetext{
${ }_{15}$ Article 24 Regulation No 1077/2011, Article 19(3) Council Regulation 2007/2004 (EC).

${ }^{16}$ Council Regulation 2007/2004 (EC) of 26 October 2004, establishing a European Agency for the Management of the Operational Cooperation at the External Borders of the Member States of the European Union.

$17<$ http://frontex.europa.eu/about-frontex/mission-and-tasks/>.

18 Article 27, Regulation (EU) No 526/2013 of the European Parliament and of the Council, of 21 May 2013 concerning the European Union Agency for Network and Information Security (ENISA) and repealing Regulation (EC) No 460/2004,

${ }^{19}$ See Article 24 Regulation No 1077/2011 of the European Parliament and of the Council of 25 October 2011 establishing a European Agency for the operational management of large-scale IT systems in the area of freedom, security and justice.

${ }^{20}$ Regulation 45/2001.

${ }^{21}$ Council Decision 2009/371/JHA of 6 April 2009establishing the European Police Office (Europol).
} 
action. However, according to Article 53(4), the jurisdiction on these matters remained with the Member States and is to be determined on the basis of national law.

This gap in EU law in terms of establishing the accountability of Europol before the EU's courts, has not passed by unnoticed. Article 88 TFEU provided for a Regulation that will be passed to replace the previous legal framework. A Regulation was proposed in May $2014,{ }^{22}$ passed in $2016^{23}$ and mentions in paragraph 56 of its Preamble that Europol should be subject to the general EU rules of contractual and non-contractual liability like any other EU agency. Article 49 of the new Regulation confers to the Court of Justice of the EU the jurisdiction for noncontractual liability of Europol and its servants. This is indeed a positive step to bring an agency of which the activity interacts strongly with individual freedoms, under the CJEU's jurisdiction, as the agency has been acquiring more powers and importance due to terrorism.

In September 2016, ${ }^{24}$ the EU Commission proposed to upgrade the European Counter Terrorism Centre within Europol and strengthen it by giving it access to EU databases, including the Visa Information System. The risk for human rights infractions seems greater, as action is taken to prevent crime and terrorism - along with these human rights infractions financial, material and moral damage is likely to occur, such as destruction of possessions and blocking of financial assets. As such, the need for a sound legal regime of compensation for any damage caused by the EU's agencies increases.

What must be pointed out is that perhaps a more holistic approach should also be applied to EU Common Foreign and Security Policy (CFSP) missions abroad and how remedies may be offered for potential human rights violations by them. Such missions may be military or civilian with the

\footnotetext{
${ }^{22}$ Proposal for a Regulation of the European Parliament and of the Council on the European Union Agency for Law Enforcement Cooperation and Training (Europol) and repealing Decisions 2009/371/JHA and 2005/681/JHA. 〈http://register.consilium.europa.eu/doc/srv?l=EN\&f=ST\%2010033\%202014\%20INIT> accessed 22 November 2015.

${ }^{23}$ Regulation (EU) 2016/794 of the European Parliament and of the Council of 11 May 2016 on the European Union Agency for Law Enforcement Cooperation (Europol) and replacing and repealing Council Decisions 2009/371/JHA, 2009/934/JHA, 2009/935/JHA, 2009/936/JHA and 2009/968/JHA.

${ }^{24}$ European Commission, Communication on Enhancing security in a world of mobility: improved information exchange in the fight against terrorism and stronger external borders, 12307/16, 19 September 2016, http://europeanmemoranda.cabinetoffice.gov.uk/files/2016/09/st12307.en16_.pdf
} 
aim of peacekeeping, conflict prevention ${ }^{25}$ in areas outside the EU which have been struck by crises.

For example, in Kosovo, the relevant EULEX mission has its own Human Rights Review Panel. Although it examines human rights complaints against EULEX officials, it cannot do more than make recommendations of a non-binding nature to the head of the Mission for remedial action, ${ }^{26}$ even where a breach of human rights is found to exist. ${ }^{27}$ As it will be seen in Section $\mathrm{D}$, the CJEU has, in principle, no jurisdiction over non-contractual liability claims in CFSP matters. ${ }^{28}$

\section{Competence areas covered}

A grey area in the provision of compensation for unlawful action - including human rights violations - is the CJEU's jurisdiction for non-contractual liability regarding the Union's external actions. Articles 42 and 43 TEU give competence to the Union under the CFSP/CSDP to conduct military and peace keeping operations. According to Article 28 TEU these operations are authorised by Council Decisions. An example given in academic writing is the EU's operation against piracy in Somalia, which includes the detention of suspected pirates. ${ }^{29}$ This clearly has potential human rights impact, in particular as regards the freedom of liberty and security (Article 6 of the Charter), the right to life (Article 2 of the Charter), the right to the integrity of the person (Article 3 of the Charter) and the prohibition of torture (Article 4 of the Charter). Papastavridis claims that the starting point for the responsibility of the EU within the EU's legal order would be Article 340(2) TFEU. ${ }^{30}$

Nevertheless, there is an obstacle to such a procedure. While Article 275 TFEU has improved the accountability of the EU's external action service by establishing that the CJEU may examine CFSP measures as to their compatibility with Article 40 TEU or if they are measures with restrictive effects on natural or legal persons as to their legality on the basis of Article 263, the CFSP remains largely outside the CJEU's jurisdiction regarding any other claim, which is

\footnotetext{
${ }^{25}$ See Articles 42 and 43 of the TEU.

26 Human Rights Review Panel, Rules of Procedure, Rule 34.

${ }^{27}$ Case No. 2012 - 14 Valbone Zahiti v. EULEX 4 February 2014, para 70.

28 cf. Lenaerts et al (n.11) 481.

${ }^{29}$ E. Papastavridis, 'EUNAVFOR Operation Atlanta off Somalia: the EU in unchartered legal waters?' (2015) 64(3) ICLQ 533-568.

30 Ibid.
} 
understood to also exclude non-contractual liability claims. This consequently leaves both a legislative and a jurisprudential gap, where there is no express provision that CFSP measures may trigger the Union's non-contractual liability. This is ever more important for human rights claims in light of the interplay that CFSP measures have with human rights. It has been claimed that this is made up by the fact that Article 19 TEU provides that the Member States also have the duty to provide remedies for fields covered by EU action. ${ }^{31}$ This however, does not rectify the fact that the CJEU is the most suitable judicial organ to rule on the lawfulness of Union action.

The CJEU position on this matter is not clear. In Mugraby ${ }^{32}$, the applicant claimed that the Union had breached his fundamental and human rights because it failed to take measures under the Association Agreement with Lebanon (for example suspending the Agreement) as such turning a blind eye to the infringements of rights in Lebanon. The Courts silently accepted that they had jurisdiction in that area with the GCEU reiterating the principle that international agreements become an integral part of EU law, ${ }^{33}$ and are binding upon it by virtue of Article 216(2). The question at hand - whether the EU failed to act vis-à-vis violations of human rights in another country under the Association Agreement has to do with the EU's activities as an international actor. The CJEU upheld the GCEU's position that the Council and the Commission have a wide margin of discretion in the management of the external relations of the Union and that the applicant did not establish the unlawfulness of the conduct and did not substantiate his claim, thus not proceeding to examine in detail the EU's omissions as an international actor.

In Zaoui ${ }^{34}$ the applicants' claim that the educational aid granted by the Union to Palestine incited hate that resulted in the deaths of the applicant's relatives was dismissed, not on the matter of jurisdiction but rather on the point of causation. Indeed, the responsibility of both states and international organisations to compensate for damage caused through their external action is

\footnotetext{
${ }^{31}$ F. Naert, 'The International Responsibility of the Union in the context of its CSDP Operations' in M. Evans, and P. Koutrakos (eds), The International Responsibility of the European Union (Hart Publishing 2013) $313,318$.

${ }^{32}$ Case C-581/11 P Mugraby, not yet reported (Grand Chamber, Order, 12 July 2012).

${ }^{33}$ Case T-292 Mugraby v. Commission and Council [2012] ECR II- 00255, see also Case 181/73 Haegeman [1974] ECR 449.

${ }^{34}$ Case C-288/03 P Zaoui v. Commission Order of the Court, 14 October 2004.
} 
an important matter, since there is the reasonable position that control creates responsibility, ${ }^{35}$ while international organisations should foresee the possible human rights implications of their actions in other countries. ${ }^{36}$

In Sison (see also Chapter 6 above) ${ }^{37}$ the applicant was a Filipino activist living in the Netherlands, whose assets were frozen by the Council by virtue of Article 2(3) of Regulation No 2580/2001, read in conjunction with Article 1(4) of Common Position 2001/931, therefore the action in question was falling under the CFSP umbrella. The applicant had invoked among other things that his rights to property and to private life had been violated. The Council in this case had not challenged the Court's jurisdiction in its pleadings and therefore the action continued without the Court raising the matter, dismissing it although due to the absence of a 'sufficiently serious breach'. This case is also evidence that the CJEU has accepted jurisdiction on CFSP matters within the context of Article 340, at least in a case where the measures taken were akin to the restrictive measures to individuals in judicial review cases.

More recently, in the context of the EU's proposed accession to the European Convention on Human Rights the Commission had made submissions that an action for non-contractual liability and damages is not excluded by Article 275 TFEU and that all measures of EU law are subject to the CJEU's jurisdiction if Articles 19(1) TEU Articles 275 and 340 TFEU and Article 1(4) of the Draft Accession Agreement were combined. ${ }^{38}$ This submission by the Commission was not accepted by the CJEU in its Opinion. Evidently, if the CJEU were found to have full jurisdiction over all measures of EU law then that would facilitate the EU's accession to the ECHR by ensuring that no dispute would reach Strasbourg before being first adjudicated in Luxembourg, something which would in theory safeguard the CJEU's exclusive jurisdiction over the interpretation of EU law. ${ }^{39}$

\footnotetext{
${ }^{35}$ R.A. Lawson, 'Life after Bankovic: On the Extraterritorial Application of the European Convention of Human Rights' in Commans F and Kamming MT. (eds) Extraterritorial Application of Human Rights Treaties (Antwerp, Intersentia, 2004), 83-125.

${ }^{36}$ M. Bulterman in O. de Schutter and P. Alston (eds) Monitoring Fundamental Rights in the EU - The Contribution of the Fundamental Rights Agency (Hart Publishing 2005), 258.

${ }^{37}$ Case T-341/07, José Maria Sison v. Council [2011] ECR II-07915

${ }^{38}$ Opinion 2/13: Opinion of the Court (Full Court) of 18 December 2014, para. 99.

39 The proposed accession provided that there should have been internal procedural rules to ensure that the CJEU would have first a say before any action against the Union would be brought before the Strasbourg Court. For more
} 
In its Opinion regarding the Accession the CJEU was careful in its wording. It pointed out that the matter of jurisdiction under Article 275 has not yet been subject to the CJEU's interpretation and did not attempt to interpret it in its Opinion, either. It instead held that:

"as EU law now stands, certain acts adopted in the context of the CFSP fall outside the ambit of judicial review by the Court of Justice... That situation is inherent to the way in which the Court's powers are structured by the Treaties, and, as such, can only be explained by reference to EU law alone". ${ }^{40}$

Therefore, the CJEU decided to stay within the restrictive wording of the Treaty and not attempt in any way to adopt an interpretation which would essentially extend its own competences. In the same context, an Advisory Opinion was also delivered by Advocate General Kokott, whose view on the Commission's arguments was more direct. Being of the opinion that the Accession was compatible with EU law and that the review of CFSP acts was something possible in national courts, she stated:

“89. First, the Commission's interpretation disregards the relationship between rule and exception that underpins Article 275 TFEU; the Commission turns the principle that the Courts of the EU have no jurisdiction in relation to the CFSP, as laid down in the sixth sentence of the second subparagraph of Article 24(1)TEU and the first paragraph of Article 275 TFEU, on its head. Secondly, in assuming that the Court of Justice has jurisdiction in preliminary ruling proceedings and actions for damages in the context of the CFSP, the Commission contravenes the clear wording of the second alternative in the second paragraph of Article 275 TFEU, which refers only to jurisdiction for actions for annulment brought by individuals in accordance with the fourth paragraph of Article 263 TFEU against restrictive measures, but not to any other subject-matter of an action or type of action, and certainly not to references from national courts or tribunals as provided for in Article 267 TFEU."

details see P. Gragl, The Accession of the European Union to the European Convention on Human Rights (Hart 2013) 272.

40 Ibid, paragraphs 249-253. 
This position regarding the scope of the CJEU's jurisdiction, despite the different conclusions of the CJEU and the Advocate General, seems to form common ground of understanding of the two.

The truth remains that the EU courts are not a forum for possible claims for damages caused by EU operations under the CFSP and this undermines the unity of remedies in EU law. It furthermore cripples in a significant way the usefulness of non-contractual liability. This need becomes more evident as the CFSP measures taken by the Union in light of the ongoing threat of terrorism which impose sanctions for persons become more and more common. ${ }^{41}$

\section{E. Conclusions}

The above analysis leads to the conclusion that apart from the restrictive approach followed by the CJEU for the satisfaction of the criteria for granting damages in a non-contractual liability claim, there is also a lack of uniformity in the jurisdiction of the CJEU. This should raise concerns as it appears that not all EU action may be subject to the same judicial or financial remedy.

The scope of application of the principle of non-contractual liability is unclear and this affects negatively the effectiveness of the principle as a means of protecting human rights against adversary Union action. Much depends on a case- by-case basis. In Ledra Advertising, ${ }^{42}$ the court was called upon to clarify whether the acts of the Commission and the ECB within the ESM could be subject to an action for damages, despite the general provision of Article 340(2) that the Union shall make good any damage caused by its institutions or by its servants. This was in light of the fact that the decision-making was made in tandem with other institutions not belonging to the EU. The examples of the FRONTEX and Europol Regulations discussed above may be significant developments in that they provide for bodies which may violate human rights to be accountable, yet they demonstrate the piecemeal approach taken by the Union in establishing the rules for liability of its institutions.

\footnotetext{
${ }^{41}$ With the development of the Islamic State, further sanctions on individuals are being implemented. For example, see the Council Regulation (EU) 2016/1686 imposing additional restrictive measures directed against ISIL (Da'esh) and Al-Qaeda and natural and legal persons, entities or bodies associated with them, 20 September 2016. 42 cf. (n.9).
} 
Similarly, there is no express provision in the Treaties or the case law whereby the CJEU is conferred jurisdiction to rule on matters of CFSP within the framework of the non-contractual liability procedure.

The above analysis reveals the lack of a holistic application of the obligation of the Union to provide effective judicial protection, which is part of fundamental rights. Article 47 of the Charter of Fundamental Rights provides that every person whose rights are violated is entitled to an effective remedy before a competent tribunal. This provision binds the Union in respect of its own activities and judicial system as well. It therefore appears that this gap in the jurisdiction of the Union judicature is not easily reconciled with this important obligation. 



\section{Part III}

\section{The European Union and International Human Rights Obligations}

The overarching question in Part III of this thesis is to examine the availability of remedies against the EU for human rights violations at the international legal level. This relates to general public international law, beyond the European Convention on Human Rights, to which the EU has long planned to accede.

The European Union has been gradually acquiring an important and central role in world affairs. Its international legal personality thus requires a set of rules through which it may function. As a preliminary topic, Chapter 9 will analyse precisely the significance of the EU's international legal personality and how this evolving international identity of the Union is in want of a set of obligations relating to the EU's action vis-à-vis human rights and a regime for the Union's responsibility on the international scene. The EU has not signed an international legal instrument which provides for the protection of a sufficient range of human rights, restricting its accession to conventions that provide protection for specific rights such as the Convention on the Rights of Persons with Disabilities.

The need for international human rights obligations for the EU is underlined by the fact that the EU's general principles as well as the Charter of Fundamental Rights are purely internal rules of the EU, serving the Union's purposes and setting the Union competences' limits but that do not extend to the scope covered by other international human rights treaties. ${ }^{1}$ In the absence of ratification of core human rights treaties, such as the International Covenant on Civil and Political Rights, the International Covenant of Social Economic and Cultural Rights or the Convention Against Torture, the EU's obligations regarding international human rights law remain within the ambit of customary international law, which may protect human rights at a minimum standard. This standard is guaranteed by jus cogens or peremptory norms which as it will be seen in detail further below, are norms which cannot be transgressed because they guarantee human dignity, as it will be seen in Chapter 10.

\footnotetext{
${ }^{1}$ European Regional Office of the United Nations' High Commissioner for Human Rights Report, 'The European Union and International Human Rights Law',

<http://www.europe.ohchr.org/Documents/Publications/EU_and_International_Law.pdf $>$.
} 
Chapter 11 will research the question of attribution. Where an international organisation is to be held responsible for the violation of an international obligation, the act in question must be attributed to that organisation. Therefore, this particular section will examine how the doctrine of attribution may be applicable to the EU in terms of its activities. Yet, beyond acts within the framework of its foreign policy, it is also important to assess the interaction between EU policies and their implementation by a Member State in light of international human rights law, as it will be seen in Chapter 12.

Given that the subject of remedies for human rights violations by the Union is the central research question of this Thesis, Chapter 13 of this Part will explore the potential application of remedies for violations of international law by international organisations on the European Union.

Chapter 14 will look at the final, practical question of procedure: the accountability of the EU before other international institutions which will be the vehicle for the obtaining of a legal or other remedy for the human right violation. In fact this Chapter will attempt to examine whether the EU may be held responsible before other international fora and how this may be complimented by alternatives. 


\section{Chapter 9}

\section{The EU and its Involvement in International Affairs}

\section{A. Introduction}

As European integration has progressed over the decades following the establishment of the European Communities, the European Union has gradually acquired powers to act in a number of fields of policy, some of which have an interaction with human rights questions. What is more, the EU has developed to a visible actor on the international stage, assuming international legal personality.

Section (B) will introduce the EU as an international, non-state actor. Section (C) will examine the particular question of the EU's common foreign and security policy and how this may influence human rights at an international level. Section (D), as a conclusion shall thereby delve into the question of necessity for a system of international human rights obligations for the EU by virtue of its international personality.

\section{B. The EU in the context of non-state actors in international law}

The early doctrine in international law is that international law only applied to states. One of the first academics to describe international law as applicable between states was one of the 'founding fathers' of international law - Hugo Grotius, in his De Jure Bellis ac Pacis. ${ }^{1}$ For Grotius a state was an association of free men made up of individuals with no separate identity. ${ }^{2}$ Before that, medieval legal discourse had developed the idea of jus gentium, an all-encompassing composition of legal rules that applied to rulers and individuals in the concept of a common religious, political and cultural unity in the western, Christian world. ${ }^{3}$

Vattel, in 1758 was clear in his Le Droit des Gens ou Principes de la Loi Naturelle, appliqués à la conduite aux affaires des Nations et des Souverains, that international law is a set of rules that apply to nations or states clearly, thus determining it to be inter-state law. Specifically, Vattel

\footnotetext{
${ }^{1}$ H. Grotius, De Jure Belli ac Pacis. Libri Tre (1625).

${ }^{2}$ P. Haggenmacher, Grotius et la Doctrine de la Guerre Juste (Paris : Presses Universitaires de France) 539-541.

3 S. Neff, 'A Short history of international Law' (ed) Evans M.D., International Law (OUP 2010) 35, R. Portmann, Legal Personality in International Law (Cambridge: Cambridge University Press 2010) 33.
} 
defined international law as 'the science of law that applies between the Nations, or States and the obligations that respond to this law'. ${ }^{4}$ This conception followed a wave of legal thought beginning in the seventeenth century which elaborated theories of the state having its own personality. ${ }^{5}$ The idea of the state being the only person involved in international law persisted well into the first half of the twentieth century. ${ }^{6}$

There is academic discussion as to whether non-state entities, such as corporations, are subjects of international law. For example, McCorquodale has stated that there is a shift of international human rights law that will lead to private, non-state actors being bound by international human rights norms. ${ }^{7}$ Certain commentators argue that international human rights law binds directly both state and non-state actors, such as Weissbrodt and Kruger, whose position, as early as 2005, was that the Universal Declaration of Human Rights creates binding legal obligations both for state as well as non-state actors. ${ }^{8}$ This is based on the statement in the preamble to the Declaration that every organ of society must strive for the protection of human rights, while Article 30 of the Declaration refers to 'every state, group or person' ${ }^{9}$ If this applies to private actors, it would not be a step too far to expect it to apply to international organisations as well.

Alston argues that international organisations are often neglected from the non-state actor discourse in international law discourse because they are not considered to be dramatically different from the state entities which make them up, ${ }^{10}$ that they have an intergovernmental nature. ${ }^{11}$ Yet legal challenges for the standing of non-state actors within the remit of international law persist in the case of international organisations as well, as it will become evident in the long run of this Chapter.

\footnotetext{
${ }^{4}$ G. Vattel, Le Droit des Gens, Préliminaires, p. 1, 'la science du droit qui a lieu entre les Nations, ou États, et des obligations qui répondent à ce droit.'

${ }^{5}$ T. Hobbes, Leviathan (1651), S. von Pufendorf De Jure Naturae et Gentium Libri Octo (1688), C. Wolff Jus Gentium, Book VII, Ch VI.

${ }^{6}$ T. Heinrich, 'Les Rapports entre le Droit Interne et le Droit International' (1923-I) 1 RCADI 77-121.

${ }^{7}$ R. McCorquodale International Law beyond the State: Essays on Sovereignty, Non-State Actors and Human Rights (Cameron May 2011) 200-22

${ }^{8}$ D. Weissbrodt and M. Kruger, 'Human Rights Responsibilities of Businesses as Non-State Actors' (2005) 13 NonState Actors and Human Rights 315, 329-30.

${ }^{9}$ C. Rose, 'The Limitations of a Human Rights Approach to Corruption' (2016) 65(2) ICLQ 404-438, 423

${ }^{10}$ P. Alston Non-state actors and human rights (OUP 2005) 29.

${ }^{11}$ Ibid.
} 
As subjects of international law, international organisations are bound by obligations upon them under general rules of international law, ${ }^{12}$ such as custom, general principles or jus cogens. The UN's committee on Economic, Social and Cultural Rights has stated in its General Comment no. 14 , in relation to the right to health, that international organisations have human rights obligations.

Reinisch points out that international organisations have gradually demonstrated the will to selfregulate their actions in relations to human rights, ${ }^{13}$ within a changing legal framework relating to the legal status of non-state actors within international human rights law. For example. The UN has voluntarily adopted its own rules for humanitarian law that apply to UN military operations by promulgating in 1999 the fundamental principles and rules of international humanitarian law applicable to United Nations forces conducting operations under United Nations command and control. ${ }^{14}$

The Parliamentary Assembly of the Council of Europe adopted in 2014 its Resolution 1979 regarding the Accountability of International Organisations for Human Rights Violations, in which it invited all the states members of the Council of Europe and the international organisations to which they are parties, to ensure that international organisations are bound by scrutiny mechanisms and that the decisions of these mechanisms are duly enforced. ${ }^{15}$ In paragraph 6 of this Resolution, the Parliamentary Assembly made specific reference to the European Stability Mechanism which is an ad-hoc body made up by the European Commission, the European Central Bank and the International Monetary Fund, and its absolute immunity which causes concerns to the Assembly. The problems that this action of the EU may cause from ensuring access to accountability mechanisms and remedies has already been discussed in

\footnotetext{
${ }^{12}$ ICJ, Interpretation of the Agreement of 25 March 1991, between the WHO and Egypt, Advisory Opinion [1980] ICJ Rep para 37, M. Shaw, International Law (4 $4^{\text {th }}$ edn 1997) 190.

${ }^{13}$ A. Reinisch, 'The Changing International Legal Framework' in cf. Alston Non-state actors and human rights (ed) (n.10) 47.

${ }_{14}$ Observance by United Nations forces of international humanitarian law, United Nations, Secretary - General's Bulletin ST/SGB/1999/13, 6 August 1999. See also Shraga D 'UN Peacekeeping Operations: Applicability of International Humanitarian Law and Responsibility for Operations - Related Damage' 94 AJIL (2000) 406.

15 Resolution 1979 (2014) Parliamentary Assembly of the Council of Europe <http://semanticpace.net/tools/pdf.aspx?doc=aHR0cDovL2Fzc2VtYmx5LmNvZS5pbnQvbncveG1sL1hSZWYvWDJILURXLWV4 dHIuYXNwP2ZpbGVpZD0yMDUxMCZsYW5nPUVO\&xsl=aHR0cDovL3NlbWFudGljcGFjZS5uZXQvWHNsdC 9QZGYvWFJIZi1XRC1BVC1YTUwyUERGLnhzbA==\&xsltparams=ZmlsZWlkPTIwNTEw>
} 
Chapter 2 with reference to Mallis, ${ }^{16}$ where the actions of the 'Troika' where held to be outside the CJEU's jurisdiction.

Although the EU is not a state, it is subject to the rules of international law when it wishes to participate on the global stage. ${ }^{17}$ Article 1 TEU is silent on whether the EU is an international organisation or something else. ${ }^{18}$ The EU is neither a state with full international powers nor a traditional international organisation bound by the will of its member states. ${ }^{19}$ The EU sometimes resembles a federated state in the sense that certain competences are reserved for the Member States while others for the EU's institutions - certain commentators have therefore attempted to characterise the EU as an international organisation with far reaching forms of cooperation and supranational features. ${ }^{20}$

Assuming that this description is a rather fitting one, it is important to mention that international organisations have a legal personality nonetheless, even if they do not fit the classical state entity profile. Article 2(a) of the International Law Commission's 2009 Articles on the Responsibility of International Organisations, which were endorsed by the UN General Assembly in December 2011, an international organisation is an organisation established by a treaty or other instrument governed by international law and possessing its own legal personality.

Therefore, according to this definition, an international organisation comes into existence where it is set up by a treaty, where it is under international law and where it has a legal personality. Indeed, the EU is set up by its two founding Treaties, while according to Article 47 the Union has its own legal personality - distinct of the one of its member states. Furthermore, Article 3(5) TEU states that the Union shall promote and uphold the strict observance of international law in its relations with the outer world. The fact that the EU is an organisation with a sui generis

\footnotetext{
${ }^{16}$ Konstantinos Mallis and Others $v$ European Commission and European Central Bank (ECB) Judgment of the Court (Grand Chamber) of 20 September 2016 ECLI identifier: ECLI:EU:C:2016:702. The first case involved an action for damages against austerity measures imposed by the Union where the Court found the Union's action capable for engaging non-contractual liability and the second one an action for annulment where the Court found that the Union's action could not be subject to review.

${ }^{17}$ B. van Vooren and R.A. Wessel, EU External Relations Law (CUP 2014) 2.

${ }^{18}$ Ibid 1,3

${ }^{19}$ Ibid, 7

${ }^{20}$ H.G. Schermers and N.M. Blokker, International Institutional Law: Unity in Diversity (Martinus Nijhoff Publishers 2011) 55, 57.
} 
structure does not eradicate its international organisation features. International organisations are diverse in nature and each is set up for specific functions that characterise its activities. ${ }^{21}$

The EU as an international organisation is a non-state actor. ${ }^{22}$ International organisations have an undisputed international legal status, distinct from that of their member states. ${ }^{23}$ As per Klabbers, as soon as an organisation performs an act which can only be explained on the basis of international legal personality, such an organisation will be presumed to be in possession of international legal personality. ${ }^{24}$

The international legal personality was recognised in the Reparations for Injuries Suffered in the Service of the United Nations. ${ }^{25}$ In this particular case the question was whether the United Nations could bring an international law claim before the ICJ for the assassination of the UN Secretary - General's envoy to Palestine and Israel by paramilitary units in Jerusalem. The Court held:

“... Throughout its history, the development of international law has been influenced by the requirements of international life, and the progressive increase in the collective activities of States has already given rise to instances of action upon the international plain by certain entities which are not States...

Accordingly, the Court has come to the conclusion that the Organisation is an international person. That is not the same thing as saying that it is a State, which it is certainly not, or that its legal personality and rights and duties are the same as those of a State. Still less is it the same thing as saying that it is a 'super-State' whatever that expression may bean. It does not even imply that all its rights and duties must be upon the international plane, any more than all the rights and duties of a State must be upon that

${ }^{21}$ G. Gaja, 'Articles on the Responsibility of International Organisations' United Nations Audiovisual Library of International Law, 3 http://legal.un.org/avl/pdf/ha/ario/ario_e.pdf (accessed 08 February 2016).

${ }^{22}$ The definition of a non-state actor in international law varies greatly see P. Alston (ed) Non-state actors and human rights (OUP 2005) 15, R. Higgot et al (eds) Non -State Actors and Authority in the Global System (2000), Bas Arts Non-State Actors in Global Governance: Three Faces of Power, Max Planck Project Group on Common Goods, Bonn, Working Paper 2003/4.

23 T. Gazzini, 'The Relationship between International Legal Personality and the Autonomy of International Organizations' in R. Collins and N.D. White (eds) International organizations and the idea of autonomy (Abingdon, Routledge 2011) 33-35.

${ }^{24}$ J. Klabbers, An Introduction to International Institutional Law (Cambridge: CUP $3^{\text {rd }}$ edn 2015) 48.

25 (Advisory Opinion) 1949 ICJ Reports 174. 
plane. What it does mean is that it is a subject of international law and capable of possessing international rights and duties and that it has the capacity to maintain its rights by brining international claims." 26

The Opinion of the ICJ has been subject to debate as demonstrating three possible conceptions of international personality. ${ }^{27}$ The first one, the "actor conception" is that the international personality did not depend on the Charter of the UN but rather on objective preconditions of customary international law. ${ }^{28}$ The formal conception is that the ICJ in fact stuck closely to the rules of the UN Charter and the rights, duties and competences that it provides. $^{29}$

Having an international legal personality, as per Wessel, essentially means that the organisation becomes subject of public international law. ${ }^{30}$ International or intergovernmental organisations have developed over the decades to become autonomous entities to the effect that their "nonstate' dimension is being highlighted rather than their composition of states. ${ }^{31}$ The third doctrine if the recognition conception according to which member states of the UN had already recognised the UN as an international legal person implicitly. ${ }^{32}$ In any situation, the ICJ's statement broke ground by opening the way for the UN to be an international legal person.

The International Law Association's Committee on the Accountability of International Organisations also published a report in 2004 in which it set out numerous practices of internal and external scrutiny and accountability of international organisations, proposing the respect of

${ }^{26} \mathrm{Ibid}, 179$.

${ }^{27}$ cf. Portmann (n.3) 102

28 A.P. Sereni Diritto Internazionale (II/2) (Milan Guiffre 1960), 843-50, F. Seyersted, 'United Nations Forces: Some Legal Problems' (1961) 37 BYIL 351-475, Sir G. Fitzmaurice 'The Law and Procedure of the International Court of Justice: International Organizations and Tribunals' (1952) 29 BYIL 1-62.

${ }^{29}$ This conception is said to follow Kelsen's theory on international law, as found in H. Kelsen, General Theory of Law and State (Cambridge (Mass.) Harvard University Press 1945), H. Kelsen, 'Théorie Générale du Droit International Public' (1932-IV) 42 RCADI 121-351.

${ }^{30}$ R.A. Wessel, 'Revisiting the international legal status of the EU' (2000) 5 European Foreign Affairs Review, 507537.

${ }^{31}$ H.G. Schermers and N. Blokker International institutional law: unity within diversity (Leiden: Martinus Nijhoff Publisher, $3^{\text {rd }}$ edn 2011) 728, R.A. Wessel 'IGOs as Non-State Actors' in M. Noorthmann, C. Ryngaert, A. Reinisch (eds), Non -state actors in international law (Hart 2015) 195.

${ }^{32}$ G. Schwarzenberger International Law: International Law As Applied by International Courts and Tribunals $\left(3^{\text {rd }}\right.$ edn Stevens and Sons 1957) 138, P. Reuter, Institutions Internationales (Paris: Presses Universitaires 1955) 316318, R. Bindschedler, 'Die Anerkennung im Völkerrecht' (1961-1962) 9 Archiv des Völkerrechts 377-97, H.G. Schermers and N. Blokker International institutional law: unity within diversity (Leiden: Martinus Nijhoff Publisher, $3^{\text {rd }}$ edn 2011) 979. 
international human rights law but also the prevention of damage to be caused by activities of international organisations. ${ }^{33}$

The most comprehensive text on the matter of accountability and remedies for violations of international law - by extent international human rights law - by international organisations are the International Law Commission's Draft Articles on the Responsibility of International Organisations. This non-binding, soft law document, draws from the International Law Commission's Articles on the International Responsibility of States and were concluded in $2011 .^{34}$ They are a result of the ILC's work which was deemed necessary in light of the everdeveloping nature and functions of international organisations. ${ }^{35}$ They deal with the matters of breach of international legal obligations, attribution and reparation and offer a comprehensive set of rules for engaging international organisations within international law and seeking remedies against them. Their specific provisions as well as application in the case of the EU is a core subject of discussion in the present Chapter, as it will be seen in all the sections to follow.

It therefore evident that there is an ongoing and developing discourse on the matter of the responsibility of international organisations as non-state actors in international law, the EU being also a subject matter of discussion in this context. It is imperative to understand therefore how it would be possible to engage the responsibility of the EU within international law with the ultimate goal of providing remedies for human rights violations it causes.

\section{The EU - an international organisation with a foreign and defence policy liable to breach human rights}

International action for the EU extends beyond the limits of the geographical boundaries set by the Member States' external borders. The EU furthermore uses its international legal personality

${ }^{33}$ Final Report, Accountability of International Organisations, International Law Association, Berlin Conference (2004).

${ }^{34}$ C. Ahlborn C., 'The Rules of International Organizations and the Law of International Responsibility', (2011) 8 International Organizations Law Review 397-482. C. Ahlborn, 'The Use of Analogies in Drafting the Articles on the Responsibility of International Organizations. An Appraisal of the 'Copy-Paste Approach"”, (2012) 9 International Organizations Law Review 53-66. C.F. Amerasinghe, 'Comments on the ILC's Draft Articles on the Responsibility of International Organizations' (2012) 9 International Organizations Law Review, 29-31. J. d'Aspremont, 'The Articles on the Responsibility of International Organizations: Magnifying the Fissures in the Law of International Responsibility' (2012) 9 International Organizations Law Review 15-28.

35 Draft Articles on the Responsibility of International Organisations, with Commentaries Yearbook of the International Law Commission, 2011, vol. II, Part Two, 46. 
to take action in international affairs, or even where it is adopting international policies that will be implemented within the territory of its Member States.

The prime example of the EU's involvement in world affairs is the Common Foreign and Security Policy. The Common Foreign and Security Policy (CFSP) is a broad area of competence of the EU which, according to Article 24(1) TEU, includes all areas of foreign policy and security including the framing of a common defence. The same provision of the TEU states that decisions in this area are to be taken by the European Commission and the Council of the European Union acting in unanimity, unless it is otherwise provided for in the Treaties. The policy making is passed through decisions and Article 24(1) TEU excludes any possible policymaking based on legislative acts.

The fact that the Union acts as a separate personality to the ones of its Member States is evident in several Treaty provisions related to the CFSP. Article 26 TEU provides that the European Council will determine the objectives and define the general guidelines of the CFSP, including matters of defence. This is also compatible with Article 15(1) which provides that the European Council shall provide the Union with the necessary impetus for its development and define the general political directions. As per Article 15(2), the European Council consists of the heads of state or government of the Member States along with the President of the European Council and the President of the Commission - the High Representative of the Union for Foreign Affairs and Security Policy shall also participate in its work. Article 15(6) TEU gives the President of the European Council the task of representation of the Union in CFSP matters ${ }^{36}$

Once the general directions or guidelines for the CFSP are outlined by the European Council, the Council of the European Union TEU shall frame the CFSP and take decisions based on the guidelines given by the European Council. ${ }^{37}$ The Council of Ministers is composed of the Foreign Affairs ministers of the Member States, thus it follows the directions of the hierarchically superior heads of states. It is chaired by the High Representative of the Union for Foreign Affairs and Security Policy, ${ }^{38}$ who has the task of representing the Union for CFSP

\footnotetext{
${ }^{36}$ According to Articles 15(5) TEU the president of the European Council, is elected by qualified majority for two and a half years, renewable once.

${ }^{37}$ Article 26(2) TEU.

${ }^{38}$ Article 27(1) TEU.
} 
matters in international organisations. The High Representative is supported by the European External Action Service (EEAS) in fulfilling these tasks.

The EEAS was set up by a Decision of the Council in $2010,{ }^{39}$ but it is yet unclear whether it is a body, an agency or an institution and whether it is autonomous or under the control of the High Representative- it has been described as a sui generis creation, as well. ${ }^{40}$ Another viewpoint is that the EEAS has no legal personality but functional legal capacity and is therefore characterised as having the same status as the Commission's Directorates General. ${ }^{41}$

The interplay of EU external action with human rights further become evident through the provisions of the Treaties that allow the Union to act in defence projects where the Member States provide the assets, and the Union is then to determine the policy and the actions. This is a specific branch of the Common Foreign and Security Policy referred to as Common Security and Defence Policy (CSDP), in Section 2 of Chapter Two of the Treaty on the European Union.

Article 42 TEU provides that the Member States shall provide the Union with an operational capacity drawing on their civilian and military assets. Article 42(1) specifically provides that the Union may use these assets on missions outside the Union for peace-keeping, conflict prevention and strengthening international security in accordance with the principles of the United Nations Charter. Article 42(4) provides that decisions under the CSDP heading shall be taken by the Council of the European Union acting unanimously after a proposal from the High Representative, or an initiative from the Member States.

Article 43 furthermore states that the Union's tasks shall include several tasks of military character such as joint disarmament, humanitarian and rescue tasks, tasks of combat forces in crisis management and also makes express provision for the combat of terrorism. Article 43 TEU also provides that the decisions regarding these tasks are to be taken by the Council and

\footnotetext{
${ }^{39}$ Council Decision 2010/427/EU, 26 July 2010, establishing the organization and functioning of the European External Action Service, OJ 2010, No. L201/30.

${ }^{40}$ A. Missiroli, 'The New EU Foreign Policy System after Lisbon: A Work in Progress' (2010) 15 European Foreign Affairs Review 427-452.

${ }^{41}$ B. van Vooren, 'A Legal Institutional Perspective on the European External Action Service' (2011) 48 CMLRev 475-502, 500 .
} 
coordinated by the High Representative under the authority of the Council and in cooperation with the Political and Security Committee. ${ }^{42}$

In return, the Union will use its assets to assist Member States in time of crisis. In the Treaty on the Functioning of the European Union, Article 222 is a solidarity clause which provides that the Union shall mobilise all the instruments at its disposal, including its military resources to assist a Member State under terrorist attack or suffering a natural or man-made disaster. Article 222(3) provides that such action will be taken by a decision adopted by the Council acting on a joint proposal by the Commission and the High Representative of the Union for Foreign Affairs and Security Policy. Furthermore, unanimity by the Council and the European Council in accordance with Article 31(1) TEU will be necessary where the action has defence implications.

The wording of the above provisions is of significance in the discussion of whether the EU may be responsible for possible human rights violations while acting in this field. It appears from the provisions that action is taken under the identity of the European Union, as not only will the missions be ordered by the Council but they will also be coordinated by a Union institution, the High Representative.

In addition, these provisions have led to the 'institutionalisation' of the CSDP by the creation of new organs, such as the EU Military Committee (the highest military body within the Council of Ministers) ${ }^{43}$ and the Political and Security Committee, referred to above.

\footnotetext{
${ }^{42}$ According to Article 38 TEU, the Political and Security Committee shall monitor the international situation in the areas covered by the Common Foreign and Security Policy. It is a Committee of the Council of the European Union and it is composed by ambassadors of the Member States of the Union. It contributes to the definition of policies by delivering opinions to the Council upon request by the High Commissioner or on its own initiative and it monitors the implementation of agreed policies. The Committee also has political control over crisis management operations. See < https://eeas.europa.eu/topics/common-security-and-defence-policy-csdp/5392/csdp-structure-instruments-andagencies_en $>$.

${ }^{43}$ A.E. Juncos and C. Reynolds, 'The Political and Security Committee: Governing in the Shadow' (2007) 12 European Affairs Review 127-147. The EU Military Committee was established by virtue of the Council Decision of 22 January 2001 and it is composed of the Chiefs of Defence of the Member States, who are regularly represented by their permanent Military Representatives and it provides the Political and Security Committee (PSC) with advice and recommendations on all military matters within the EU. The EU Military Committee has a permanent Chairman, selected by the Chiefs of Defence of the Member States and appointed by the Council for three years. See also $<$ https://eeas.europa.eu/headquarters/headquartershomepage_en/5428/European\%20Union\%20Military\%20Committee\%20(EUMC)>
} 
Further institutionalisation is promoted by new developments with permanent structured cooperation in defence, by virtue of Article 42(6) TEU and also Protocol 10 to the TEU. ${ }^{44}$ However, it must be noted that no general European Army has been set up by these provisions, as this would not be acceptable by some Member States. ${ }^{45}$

In 2017, 23 Member States signed the joint notification for the Permanent Structured Cooperation whereby they called upon the Council of the EU and the High Representative, to adopt a Decision establishing permanent structured cooperation in the field of defence pursuant to Protocol 10 to the Treaty on the European Union, which will ensure further investment in defence and development of the CSDP. In fact the Member States stated in Annex I of the Joint Notification, have mentioned that the adoption of such a legal framework would be a step towards a common defence, as a long term vision of PESCO 'could be to arrive at a coherent full spectrum force package -in complementarity with NATO'. ${ }^{46}$ On 11 December 2017, Council decision (CFSP) 2017/2315 of 11 December $2017^{47}$ formally established PESCO with 25 Member States participating. This permanent structured cooperation allows member states to develop and invest in shared capability projects, and enhance the operational readiness and contribution of their armed forces. The difference between PESCO and other forms of cooperation is the legally binding nature of the commitments undertaken by the participating Member States. ${ }^{48}$ Several projects are ongoing in the area of defence with the Council assessing the Member State's actions for the implementation of PESCO goals. ${ }^{49}$

Protocol 10 in its preamble also mentions that the common security and defence policy forms an integral part of the common foreign and security policy and redirects to Article 43 TEU, mentioning that the performance of tasks under the CSDP is to be undertaken by capabilities

\footnotetext{
${ }^{44}$ S. Biscop, 'Permanent Structure Cooperation and the Future of ESDP: Transformation and Integration' (2008) 13 European Affairs Review, 431-448.

45 cf. van Vooren and Wessel (n.17) 410.

46 Notification on Permanent Structured Cooperation of 13 November 2017 to the Council and the High Representative of the Union for Foreign Affairs and Security Policy < http://www.consilium.europa.eu/media/31511/171113-pesco-notification.pdf>

47 Council Decision (CFSP) 2017/2315 of 11 December 2017 establishing permanent structured cooperation (PESCO) and determining the list of participating Member States.

$48<$ https://pesco.europa.eu/about/ $>$

${ }^{49}<$ https://www.consilium.europa.eu/en/press/press-releases/2019/05/14/defence-cooperation-council-assessesprogress-made-in-the-framework-of-pesco-after-first-year-of-implementation/ >
} 
which may be provided by the Member States but they are in accordance with the principle of a single set of forces.

Indeed the European Union has set out missions, most of which are civilian, although there are some purely military or mixed. ${ }^{50}$ The EU gives high priority to the role of security and state police, some of these missions included rescue operations and enforcement as well. ${ }^{51}$ Consequently, the EU has been involved in state building by sending troops and police forces to help establish law and order as well as deploy civilian capacity to address rule of law and civilian security. ${ }^{52}$

For example, in the case of Palestine, the European Union set a civilian mission which facilitated the flow of people between Egypt and the Gaza Strip and it also established the European Union Police Co-ordination Office for Palestinian Police Support, which aims to assist the Palestinian Civil Police by mentoring and advising it, to co-ordinate and facilitate EU member financial assistance to the Palestinian Civil Police and to give advice on politically related Criminal Justice elements. ${ }^{53}$ This civilian mission may influence the rights of persons related within the scope of its activity, such as their right to liberty and security, ${ }^{54}$ punishment and sanctions for criminal offences ${ }^{55}$ and the right to a fair trial. ${ }^{56}$

There are several other such missions of which the areas of action may have a direct impact on human rights. The Council Joint Action 2005/889/CFSP of 12 December 2005 on establishing a European Union Border Assistance Mission for the Rafah Crossing Point, for example established a mission, with the task of monitoring the movement through the Rafah Crossing

\footnotetext{
${ }^{50}$ For example, the EU Military Operation in Bosnia and Herzegovina (BiH) (EUFOR-Althea), the EU Police Mission in Bosnia-Herzegovina (EUPM), the European Union rule of law mission in Kosovo (EULEX Kosovo), the EU Police Advisory Team in the Former Yugoslav Republic of Macedonia (EUPAT), the EU Military Operation in the former Yugoslav Republic of Macedonia (FYROM) (Concordia) and the EU Police Mission in FYROM (Proxima).

${ }^{51}$ A. Sari, 'Status of Forces and Status of Mission Agreements under the ESDP: The EU's Evolving Practice' (2008) 19 EJIL 67-100, 71.

${ }^{52}$ A. Berg 'The EU's Experience with Security Sector Governance', (2011) United States Institute of Peace Special Report 265, 8.

${ }^{53}$ Council Joint Action 2005/797/CFSP of 14 November 2005 on the European Union Police Mission for the Palestinian Territories OJ L 300.

${ }^{54}$ Article 6 of the EU Charter of Fundamental Rights, Article 5 ECHR.

${ }^{55}$ Article 7 ECHR, Article 50 of the EU Charter of Fundamental Rights.

${ }^{56}$ Article 6 ECHR, Articles 47 to 50 of the EU Charter of Fundamental Rights.
} 
Point. ${ }^{57}$ In this field of action it is possible that the EU's staff may limit a person's freedom and liberty to move and it is necessary that protection against potential disproportional limitations of rights be established. Other examples of operations that are related to human rights are operations launched in the Democratic Republic of the Congo and counter-piracy missions off the coast of Somalia, ${ }^{58}$ while the EU has also set up FRONTEX as an agency launching operations for the security of the EU's external borders. Any such action, which may involve the restriction of persons, ${ }^{59}$ or any use of force has immediate interaction with human rights and international law, particularly when it is taken outside the EU's territory of the Member States.

\section{Conclusion}

The role of the EU in the international scene is expanding and resembling more and more the role played by the United Nations or even NATO. Therefore, it is reasonable to argue that through its actions, the European Union willingly takes the risk of violating international human rights norms by establishing itself at the heart of the field of application of international law.

Internal Union law provides for the responsibility of the Union for its actions be they within the remit of the EU or outside it. For example, the Union may be responsible for acts for its institutions in the context of damages claims in Article 340(2) TFEU, in the context of judicial review as per Article 263 TFEU. This may also apply to external action and the CFSP. Article 51 of the Charter of Fundamental Rights, provides for the EU's responsibility for the respect of human rights. Similarly, the Union as an international actor ought to act in accordance with the principles and norms of international human rights or humanitarian law. ${ }^{60}$

57 Common Security and Defence Policy of the European Union: Missions and Operations Annual Report 2016, EEAS Publication 2016, <http://eupolcopps.eu/sites/default/files/newsletters/e_CSDP_Annual\%20Report.pdf>

58 K. Engberg, 'Ten Years of EU Military Operations $\langle$ http://www.iss.europa.eu/uploads/media/Brief 41_EU military operations.pdf > p 2.

${ }^{59}$ This may potentially lead to inhuman or degrading treatment prohibited by Article 3 of the ECHR and Article 4 of the EU Charter of Fundamental Rights and customary international law, and the deprivation of liberty and security against Article 7 of the EU Charter and Article 5 of the ECHR.

${ }^{60} \mathrm{G}$ de Búrca, 'The European Court of Justice and the International Legal Order After Kadi', (2009) 51(1) Harv ILJ 1, 29 and F. Naert, International Law Aspects of the EU's Security and Defence Policy (Intersentia 2010) 
In particular to the CSDP, its purpose is to also promote and protect human rights in its crisis management operations. ${ }^{61}$ Furthermore, Article 3(5) TEU reminds that 'in its relations with the wider world, the Union shall contribute to the strict observance and the development of international law'. It is argued that although these provisions concern varying matters of substantive and procedural law, they can be seen as embodying a broader principle of responsibility which transpires EU law. ${ }^{62}$

Yet, the conclusion to be drawn in this Chapter is that beyond the internal remedies, EU action should be effectively scrutinised on the basis of international human rights law when the EU is liable to breach it, externally. That means that there could also be a set of human rights obligations for the EU which will apply both in the application of EU law and measures within the Member States, but also in its action in the international sphere. This could lead to the obtention of remedies for human rights violations, beyond the ones provided by EU law per se.

${ }^{61}$ H. Hazelzet, 'Common Security and Defence Policy: What Nexus between Human Rights and Security?', in A. Sari, and R.A. Wessel (eds), Human Rights in EU Crisis Management Operations: A Duty to Respect and to Protect? (The Hague: CLEER Working Paper Series 2012/6).

${ }^{62}$ F. Hoffmeister, 'Litigating against the European Union and its Member States - who responds under the ILC's Draft Articles on international responsibility of international organizations?' (2010) 21(1) EJIL. 723-747, 740. 


\section{Chapter 10}

\section{Does the EU have international human rights obligations?}

\section{A. Introduction}

The activities of the European Union infiltrate situations where human rights are vulnerable, and its international legal personality allows the Union to act in an identity separate of its Member States when it is directing action with an international aspect, but also where it is implementing its policies.

In this particular Chapter, the topic of research is whether such responsibility may be engaged at the level of international law, beyond the Union's legal system for the purposes of obtaining the corresponding remedies for the harm caused by the violation of the human rights rule.

If the Union has an international legal personality and it is indeed acting in a manner which is contrary to human rights, no responsibility can possibly arise if there is no legal obligation that has been breached. This leads to the central question of this Chapter - whether the European Union is in any way bound by human rights obligations at the international level, beyond the sphere of its own territory and the fundamental rights principles that have been developed internally in its primary law and case law.

Firstly, this Chapter will deal with the question of the need for the existence of an international obligation for the EU as an international actor, in order for the victim of a human rights violation to be able to claim any remedy against the Union. Section $\mathrm{C}$ will then discuss the problem of absence of a binding legal instrument for human rights protection for the EU and the problems this poses on engaging the EU's international legal responsibility. Section D shall therefore explore whether the EU's responsibility may be engaged through 'indirect' international legal obligations flowing from the EU's member states.

On the basis of a lack of binding international human rights obligations for the EU, and depending only on possible indirect or informal obligations, one must seek whether it is possible for the EU to be bound by international human rights obligations flowing from customary 
international law (Section E). Section F will therefore conclude on the discussion regarding the existence of international human rights obligations for the EU.

\section{B. The conditions for the existence of an international obligation}

The Union is an international organisation. The topic of the responsibility of international organisations has developed as a separate academic and legal question in comparison to private entities, or NGOs. The problem which arises in the context of international organisations is that there are substantial obstacles to hold them accountable for human rights violations. ${ }^{1}$ At a national law level, the rule is that international organisations are usually exempted from the domestic legal system, and enjoy immunity due to their independent functioning. ${ }^{2}$ In international law, that would only be possible if the international organisation is to join an international human rights treaty which will generate obligations. ${ }^{3}$

The international legal responsibility of international organisations is a legal doctrine subject to ongoing development and interpretation. For guidance on the subject of international organisations, one may turn to the International Law Commission. The Commission has issued the Draft Articles on State Responsibility (henceforth "the ILC Articles"), while in the case of International Organisations, the ILC issued the Articles on the Responsibility of International Organisations (henceforth "the ARIO”).

For international legal responsibility in both cases, it is required that there is conduct, attributable to the relevant State/international organisation, and the subsequent breach, by that conduct, of an international legal obligation. ${ }^{4}$

The Articles on the Responsibility of International Organisations are a piece of evidence of acceptance by the UN that, at least in principle, international organisations ought to be subject to international law. As per Articles 4(2) and 10 of the ARIO, in order to establish a breach of an international obligation, there needs to be first a binding obligation. The second criterion for

\footnotetext{
${ }^{1}$ M. Nowak and K.M. Januzewski 'Non-State Actors and Human Rights' in Noorthmann M., Ryngaert C., Reinisch A., (eds). Non -state actors in international law (Hart 2015), 156.

${ }^{2}$ Reinisch A., International Organizations before National Courts (Cambridge, Cambridge University Press, 2000).

${ }^{3}$ cf. Nowak and Januzewski K.M. (n.1) 157.

${ }^{4}$ Article 2 of the ILC Articles and Article 4 ARIO.
} 
responsibility in Article 4(2), after attribution, is that the international organisation needs to have an obligation that has been breached. Article 10 provides that the international organisation is responsible only when the obligation in question was binding on it at the time of the alleged breach.

In terms of the European Union, therefore, the question is whether the EU actually has any binding international human rights obligations. International law obligations are binding upon the Union, where the Union concludes an international agreement. This was ruled relatively early in the history of the Union's jurisprudence by the CJEU in Haegeman. ${ }^{5}$ The CJEU held that where the Union enters into an international agreement, that agreement becomes an integral part of Union law. The CJEU has formulated specific circumstances where an international treaty is given effect. Per Intertanko 6 the CJEU will examine whether the nature and broad logic of the treaty and whether the preamble and terms are such that it is possible to allow the treaty to be used as a standard of review of EU acts before the Courts under Article 263 TFEU. The norm invoked must be unconditional and sufficiently precise to be used as a standard of review. ${ }^{7}$

Where the Union has acceded to an international agreement of which the enforcement is overseen by an international tribunal or monitoring body, it is possible to bring the Union before that body, such as in the EC-Hormone ${ }^{8}$ and EC-Bananas cases $^{9}$ at the WTO panel, discussed above, given that the European Union is a party to the WTO and as such bound by its treaties the Member States of the European Union are also parties to the WTO and the EU Commission is considered to represent them as well in the WTO, ${ }^{10}$ thus making any decisions on the EU binding on the Member States as well.

Article 3(5) TEU states that the EU shall uphold and promote strict observance and the development of international law and respect for the principles of the UN Charter. This includes the protection of human rights, in particular the rights of the child. However, this provision cannot be invoked outside the European Union judicature in international law - which is the

\footnotetext{
${ }^{5}$ Case 181/73 Haegeman v. Belgian State [1974] ECR 449.

${ }^{6}$ Case C-308/06, International Association of Independent Tanker Owners (Intertanko) and others $v$ Secretary of State for Transport [2008] ECR I-4057 $\$ 54$.

${ }^{7}$ Case C-366/10 Air Transport Association of America and Others ECLI:EU:C:2011:864 §74.

${ }^{8}$ EC - Measures Concerning Meat and Meat Products (Hormones), WT/DS26.

${ }^{9}$ EC - Regime for the Importation, Sale and Distribution of Bananas, WT/DS27.

10 <https://www.wto.org/english/thewto_e/countries_e/european_communities_e.htm>
} 
question examined here - as the general rule is that the agreements between third parties create neither rights nor obligations (pacta tertiis nec nocent nec prosunt). ${ }^{11}$

This means that an agreement that is entered into by two or more parties cannot be relied upon by a party outside those signatories to the agreement. In this case, the fact that the Union has made this pledge in its founding Treaties is not directly invokable at an international level - as the Treaties only create obligations for the EU and its Member States towards one another, and cannot be invoked by any third parties although it does carry considerable weight as a statement of principle. Therefore, one ought to examine to what extent the EU has a binding international obligation for the respect of human rights which stems from the fabric of international law.

\section{The necessity of accession to a multilateral international human rights instrument guaranteeing a sufficient range of human rights}

Whilst the EU is a party to various international agreements, the Union has neither signed nor ratified any multilateral international instrument that directly deals with the subject of human rights beyond the Convention on the Rights of Persons with Disabilities, which was ratified in 2010. This Convention is primarily concerned with the implementation of measures for the guarantee of non-discrimination of disabled people although it does create obligations for the parties to it to take measures to prevent inhuman and degrading treatment ${ }^{12}$ of disabled persons and action for the protection of persons with disabilities in humanitarian crises, ${ }^{13}$ which may potentially have an interplay with the EU's international action.

This is explained by Articles 10 and 19 TFEU which require the EU to take action combat discrimination based on sex, racial or ethnic origin, religion or belief, disability, age or sexual orientation. Indeed, the EU has laid down an extensive legal framework in the area of non-

\footnotetext{
${ }^{11}$ Article 34 Vienna Convention on the Law of Treaties.

12 Article 15: Freedom from torture or cruel, inhuman or degrading treatment or punishment 1 . No one shall be subjected to torture or to cruel, inhuman or degrading treatment or punishment. In particular, no one shall be subjected without his or her free consent to medical or scientific experimentation. 2. States Parties shall take all effective legislative, administrative, judicial or other measures to prevent persons with disabilities, on an equal basis with others, from being subjected to torture or cruel, inhuman or degrading treatment or punishment.

13 Article 11 States Parties shall take, in accordance with their obligations under international law, including international humanitarian law and international human rights law, all necessary measures to ensure the protection and safety of persons with disabilities in situations of risk, including situations of armed conflict, humanitarian emergencies and the occurrence of natural disasters.
} 
discrimination, ${ }^{14}$ and the EU's role in promoting equal treatment has been extremely important historically, with the foundations set by Article 119 of the EEC, later on Article 157 TFEU which provided for equal pay between men and women. This being the starting point of nondiscrimination policies, the CJEU broke ground in Defrenne v. Sabena, ${ }^{15}$ whereby it ruled that Article 119 had a direct effect on Member States which had to ensure that undertakings implemented the equal pay principle and that social objectives of the Community intend to ensure social progress and seek the constant improvement of the living and working conditions of its peoples.

As non-discrimination progressed to engulf many types of discrimination, the Council Directive 2000/78/EC established a general framework for equal treatment in employment and occupation with express references to sexual orientation, religious belief, age and disability. Indeed this has generated a large body of case law in the $\mathrm{CJEU},{ }^{16}$ where the protection against disability discrimination has been extended to persons who are caring for disabled people ${ }^{17}$ and illnesses which lead to physical, mental or psychological impairments. ${ }^{18}$ The adoption of this particular Convention has been argued to be the instigation of the proposed equal treatment directive. ${ }^{19}$

Therefore, the EU's own equality and non-discrimination policy is extensive and a field of rigorous activity, which demonstrates that the EU has so far only been confident enough to enter into a convention of which the obligations imposed on the EU are under relatively limited danger of being breached.

\footnotetext{
${ }^{14}$ Race Directive 2000/43, Framework Employment Directive 2000/78, EU Framework Decision 2008/913/JHA Combating racist and xenophobic expression, Directive 2006/54 known as the Recast Equal Treatment Directive, Directive $79 / 7$ on gender equality on social security, Directive 2004/113 on equality in the access to and supply of goods and services, Directive 2010/41 on the equality of treatment between self-employed men and women , Directives 92/85 on pregnancy and 2010/18 on parental leave.

${ }^{15}$ Case 43/75 [1976] ECR 455

16 For an overview, see C. O'Brien 'Equality's False Summits: New Varieties of Disability Discrimination, 'Excessive' Equal Treatment and Economically Constricted Horizons' (2011) ELR 26.

${ }^{17}$ Case C-303/06 Coleman v. Attridge Law [2008] ECR I-5603.

${ }^{18}$ Cases C-335 and 337/11 Ring and Skouboe Werge v. Dansk amennyttigt Boligselskab EU:C:2013:222.

${ }^{19}$ L. Waddington 'Future Prospects for EU Equality Law: Lessons to be Learnt from the Proposed Equal Treatment Directive' (2011) 36 ELR 163.
} 
However, even there the generation of obligations for the EU by the Convention has been challenged in this context in $Z,{ }^{20}$ the CJEU held that the CPRD's provisions were not considered unconditional and sufficiently precise and therefore they did not have a direct effect on European Union law, precluding the CPRD from being a standard of review of validity of EU acts, characterising the convention as 'programmatic'. This reveals the CJEU's wariness of accepting that the EU has human rights obligations stemming directly from international law, thus being inconsistent with the action of ratification of the Convention. What is more, the European Union has not signed or ratified the Convention's Optional protocol, which provides the Committee of the Convention on the Rights of Persons with Disabilities the competence to examine individual complaints against the parties to it, ${ }^{21}$ and proceed to recommendations to the parties for remedying the violation.

Furthermore, the Council of the European Union issued a decision providing for the accession of the Union to the Council of Europe's Istanbul Convention for the prevention of violence against women and the Convention was signed in 2017. ${ }^{22}$ Again this is a convention which provides protection in a specific area related to human rights, directed to specified categories of victims and violations of specific human rights and neither does it provide for individual complaints. ${ }^{23}$

In any case, the EU has so far not acceded to a multilateral international instrument which guarantees the wider spectrum of human rights, ${ }^{24}$ such as the International Covenant of Civil and Political Rights, the International Covenant on Economic, Social and Cultural Rights, or the European Convention on Human Rights.

\footnotetext{
${ }^{20}$ Case C-363/12 Z v. A Government Department EU:C:2014:159. In this case the CJEU held in $\S 88$ of its judgment "Therefore, as the Advocate General noted in point 114 of his Opinion, in so far as the obligations imposed by that Convention are addressed to Contracting Parties, that international agreement is 'programmatic'."

${ }^{21}$ Article 5 of the Optional Protocol provides that after examining an individual complaint it may make observations and recommendations to the party against which the complained was launched. It is also possible to have interim measures that may prevent further damage to be caused to the victim.

${ }^{22}$ Council Decision (EU) 2017/865 of 11 May 2017 on the signing, on behalf of the European Union, of the Council of Europe Convention on preventing and combating violence against women and domestic violence with regard to matters related to judicial cooperation in criminal matters.

23 <https://rm.coe.int/16806fcd9d>

${ }^{24}$ The European Union has signed and ratified international instruments which are of human rights concern, such as the United Nations Convention against Transnational Organized Crime and its Protocols on the Prevention on Trafficking of Human Beings especially Women and Children and the Prevention of Smuggling of Migrants, yet it has not acceded to any multilateral instrument concerning human rights per se other than the CRPD.
} 
The lack of a comprehensive international human rights commitment leaves the CJEU to have the exclusive task of adjudicating human rights questions regarding Union action, even where this action has extraterritorial effects, as in the framework of the CFSP and the CSDP. This entails the risk of the CJEU developing its own system of interpretation regarding human rights, which is not necessarily fully compatible with international human rights standards. The Regional Office of the United Nations High Commissioner for Human Rights ${ }^{25}$ has pointed to the fact that the EU has followed a restrictive approach regarding the human rights obligations which does not embrace the concept of positive human rights obligations, but rather the concepts of respecting and promoting human rights - which differ from the obligation to take positive steps to prevent, for example, institutions or Member States from infringing human rights.

The Report makes reference to the decision of the CJEU in Parliament $v$. Council ${ }^{26}$ regarding the Family Reunification Directive, which the Parliament found as contrary to the right to family life due to restrictions of 'integration' of the child, imposed on reunification as well as due to the requirement that the application be filed before the child reaches the age of fifteen. The question was whether in this way the EU was also directing Member States to act contrary to right to family life. The CJEU stated the following:

"It cannot be regarded as running counter to the fundamental right to respect for family life or to the obligation to have regard to the best interests of children, either in itself or in that it expressly or impliedly authorises the Member States to act in such a way.

In the final analysis, while the Directive leaves the Member States a margin of appreciation, it is sufficiently wide to enable them to apply the Directive's rules in a manner consistent with the requirements flowing from the protection of fundamental rights."

The European Regional Office of the UN High Commissioner for Human Rights has suggested that the EU could accede to UN human rights treaties if these are amended by an additional

\footnotetext{
${ }^{25}$ European Regional Office of the United Nations' High Commissioner for Human Rights Report, 'The European Union and International Human Rights Law', p. 13 <http://www.europe.ohchr.org/Documents/Publications/EU and_International_Law.pdf $>5$.

${ }^{26}$ Case C-540/03, Parliament v Council [2006] ECR I-5769, §§103-104
} 
protocol, as it has been done with the Convention on the Rights of People with Disabilities, ${ }^{27}$ and that the lack of accession to an international human rights treaty should not prevent the EU from acting unilaterally as if it had acceded.

The most notorious attempt to create concrete and precise human rights obligations for the Union as a whole at an international level is the proposed accession of the Union to the European Convention on Human Rights - a procedural step which has been discussed for decades and provided for in the Lisbon Treaty. This has come to at least a provisional halt due to the CJEU's prohibitive opinion. $^{28}$

\section{The alternative solution of indirect obligations and indirect review}

Even in situations where an international organisation's Member States are bound by a human rights instrument, this does not give jurisdiction to the corresponding monitoring body of that human right instrument to rule on the international organisation's conduct when that falls outside its jurisdiction, even if the acts took place in a member state. For example, in H.v.d.P. v. Netherlands $^{29}$ before the United Nations Human Rights Committee, a communication concerning the conduct of an international organisation, the European Patent Office, was held to be inadmissible, because that conduct could not:

"in any way, be construed as coming within the jurisdiction of the Netherlands or of any other State party to the International Covenant on Civil and Political Rights and the Optional Protocol thereto".

It is possible that where the State may be brought before a monitoring body or a court overseeing the enforcement of a human rights instrument, the EU's acts may be reviewed if they are considered to be acts of the State in question. Nevertheless, one should not expect unconditional willingness by one international institution to review the acts of another international organisation without the latter's express consent.

\footnotetext{
${ }^{27}$ B. van Vooren and R.A. Wessel, EU External Relations Law - Texts, Cases and Materials (CUP 2014) 15.

${ }^{28}$ Opinion 2/13: Opinion of the Court (Full Court) of 18 December $2014 \S 99$.

${ }^{29}$ H.v.d.P. v. Netherlands Communication No 217/1986, UN Doc CCPR/C/29/D/217/1986, IHRL 2500 (UNHRC 1987), 8th April 1987, Human Rights Committee [UNHRC].
} 
The best example is the ECtHR's decision in Bosphoros. ${ }^{30}$ This case regarded the seizing by the Irish authorities of a Turkish registered plane within the framework of Ireland's obligations under EC Council Regulation 990/93 which, in turn, had implemented the UN sanctions regime against the Federal Republic of Yugoslavia (Serbia and Montenegro). It held that a state's actions will be presumed compliant with the Convention when they fulfil international obligations, if the relevant organisation offers a system of human rights protection equivalent to that of the Convention, unless the protection offered in the particular claim was "manifestly deficient".

In that case the ECtHR retains the right to review the compatibility of the obligation with human rights. The ECtHR gave itself the competence to exercise an external control over EU acts through its Member States, while also showing respect to the EU through the "presumption". This case demonstrates a respect by one European organisation for the authority of another European Organisation. ${ }^{31}$

In the context of the European Social Charter, the European Committee on Social Rights conducted indirect review, albeit without referring specifically to the matter of reviewing the compatibility of an EU act with the ESC. The complaint Federation of employed pensioners of Greece (IKA-ETAM) v. Greece, ${ }^{32}$ regarded the reduction of pensions by the Greek government in the framework of austerity measures, imposed by Memoranda signed with the European Commission. The Committee's position was clear that these obligations could not waive Greece's obligations to respect social rights as safeguarded in the Charter:

"50. With regard to the observation made by the Government to the effect that the rights safeguarded under the 1961 Charter have been restricted pursuant to the Government's other international obligations, namely those it has under the loan arrangement with the EU institutions and the International Monetary Fund, the Committee considers that the fact that the contested provisions of domestic law seek to fulfil the requirements of other legal obligations does not remove them from the ambit of the Charter. It has previously concluded to this effect in relation to national provisions enacted by states parties to the Charter which

${ }^{30}$ Bosphoros Hava Yollari Turizm Ve Ticaret Anonim Sirketi v. Ireland (App No.45036/98) ECtHR 30 June 2005 (2006) 42 EHRR 1.

${ }^{31}$ S. Douglas-Scott, "A Tale of Two Courts: Luxembourg, Strasbourg and the Growing European Human Rights Acquis" (2011) 43 CMLRev 629, 640.

${ }^{32}$ Complaint No. 76/2012, Decision on the Merits, $7^{\text {th }}$ December 2012. 
were intended to implement European Union directives or other legal norms emanating from the European Union (see Confédération générale du travail (CGT) v. France; Complaint No. $55 / 2009$, decision on the merits of 23 June 2010, §32; Confédération Française de l'Encadrement (CFE-CGC) v. France, Complaint No. 16/2003, decision on the merits of 12 October 2004, §30).

51. In the same context, the Committee has held also that when states parties agree on binding measures, which relate to matters within the remit of the Charter, they should - both when preparing the text in question and when implementing it into national law - take full account of the commitments they have taken upon ratifying the European Social Charter. It is ultimately for the Committee to assess compliance of a national situation with the Charter, including when the implementation of the parallel international obligations into domestic law may interfere with the proper implementation of those emanating from the Charter (CGT v. France; Complaint No. 55/2009, referred to above, §33).”

By conducting indirect review, the European Social Rights Committee found a violation of Article 12(3) of the Charter. This is a significant example where an international human rights monitoring body has effectively conducted indirect review and engaged the state's responsibility for acts it has adopted pursuing its international obligations.

Nevertheless, such a bold presumption has not been taken beyond these institutions of the Council of Europe, therefore the more formalistic approach of the Human Rights Committee ${ }^{33}$ may also exist. Consequently, indirect review of the compatibility of acts of international organisations with human rights may be conducted through applications against states; this however depends on the institutional framework and it is not a universally accepted practice.

Some have gone far enough to suggest that the EU could also be considered as a regional organisation under the UN Charter, Chapter VIII, because it has assisted the UN many times in peace- related operations. This would constitute the EU's actions in that capacity subject to the obligations for the non-use of force and protection of human rights in the UN charter, although

${ }^{33}$ H.v.d.P. v. Netherlands Communication No 217/1986, UN Doc CCPR/C/29/D/217/1986, IHRL 2500 (UNHRC 1987), 8th April 1987, Human Rights Committee [UNHRC]. 
indirectly through the UN. ${ }^{34}$ This suggestion of course is further complicated by questions of attribution and responsibility of international organisations, as they will be discussed further below.

\title{
E. Obligations arising out of customary international law and jus cogens
}

International legal obligations are not limited to agreements, conventions or treaties. An important source of such obligations is customary international law. Customary international law is a form of unwritten or uncodified international legal rules that are held to be binding where, according to the ICJ in North Sea Continental Shelf, there is an established state practice and also a belief that the practice is compulsory due to a rule of law which requires it (opinio juris). The ICJ had specifically stated:

\begin{abstract}
"Not only must the acts concerned amount to a settled practice, but they must also be such, or be carried out in such a way, as to be evidence of a belief that this practice is rendered obligatory by the existence of a rule of law requiring it. The need for such a belief, ie, the existence of a subjective element, is implicit in the very notion of the opinion juris sive necessitatis" 35
\end{abstract}

In 1997, the CFI in Opel Austria ${ }^{36}$ made an express reference to the principle of customary international law which the Union ought to adhere to: the principle of good faith, and also referred to the recognition of this customary law principle by the International Court of Justice, ${ }^{37}$ stating that this amounted to also the Union being bound by this customary law principle. This is indeed important, as it is also recognition of the ICJ's jurisdiction over customary international law and the force of its decisions for the EU.

The recognition of the fact that customary international law binds the Union is of importance regarding human rights. Whether human rights obligations can be generated through customary

\footnotetext{
34 cf. van Vooren and Wessel (n.27) 434, see also White N.D. 'The EU as a Regional Security Actor within the International Legal Order in Trybus M. and White (eds) European Security Law' (OUP 2007).

${ }^{35}$ North Sea Continental Shelf, Judgment, ICJ Reports 1969, p. 3, para 77.

${ }^{36}$ Case T-115/94 Opel Austria v. Council [1997] ECR II-39.

37 The German Interests in Polish Upper Silesia, Judgment of 25 May 1926, CPJI, Series A, No 7, pp. 30 and 39
} 
law remains a controversy. ${ }^{38}$ Nevertheless, there are certain human rights that are indeed part of customary international law - the prohibition of slavery and inhuman an degrading treatment and therefore even if the Union has not acceded to any other international human rights instruments it is still bound by this minimum standard. ${ }^{39}$

Not all human rights are guaranteed by customary international law. The only human rights that are protected by customary international law are the ones contained in jus cogens or peremptory norms. The most important such customary law rules are jus cogens or peremptory norms - they are rules from which no derogation is permitted and which can only be amended by a new general norm of international law of the same value, a definition which derives from Article 53 of the Vienna Convention of the Law of Treaties (VCLT). ${ }^{40}$. This provision states that no international agreement may be valid should it conflict with such a norm. The ICJ in Nuclear Weapons $^{41}$ characterised these rules as the "intransgressible" principles of customary international law.

It is useful to mention that during the procedures before the finalisation of the Vienna Convention, the ILC also published a report, ${ }^{42}$ where it laid down the rationale for the existence of jus cogens. According to the ILC, it was difficult to sustain that States have international obligations only once they "contract out" to them in the form of an agreement. There was, according to the ILC, the need for the codification of jus cogens norms from which no derogations could be taken. The ILC furthermore stated that it is the content of a norm which makes it jus cogens and that most international law norms have no such content. Therefore, there arises the question of what kind of content or subject matter, constitutes an international norm part of jus cogens.

In 1966, the International Law Commission published the Commentary on the VCLT, and as regards Article 53 it made certain suggestions regarding what could be included in the newly formulated concept of jus cogens. While there was a more general comment that peremptory

\footnotetext{
${ }^{38}$ H. Thirlway, 'The Sources of International Law' in (ed) M.D. Evans, International Law (OUP 2010) 105.

${ }^{39}$ Barcelona Traction, Light and Power Company, Limited (Belgium v. Spain), Second Phase, Judgment of 5 Feb. 1970 [1970] ICJ Rep 3

${ }^{40}$ D. Shelton, 'International Law and "Relative Normativity"' in (ed) M.D. Evans, International Law (OUP 2010) 146.

${ }^{41}$ Legality of the Threat or Use of Nuclear Weapons [1996] ICJ Rep $226 \S 79$.

${ }^{42}$ Vol. I, ILC Yearbook (1963), pp. $291-291$
} 
norms included human rights as a notion, the ILC made express reference to genocide, trade in slaves and piracy, reminding that every State has the obligation to supress these acts. ${ }^{43}$ This may be linked with the concept of erga omnes obligations, whereby the obligation is owed to the international community as a whole.

There is general academic consensus that the basic human rights standards of prohibition of torture, aggression, and of genocide, the basic rights of the human person, including protection from slavery and racial discrimination are guaranteed by jus cogens. ${ }^{44}$ This is supported by the express deliberations of the ICJ in the Barcelona Traction Case. ${ }^{45}$ In this case Barcelona Traction, a corporation, was sold with little paid to the majority of its Belgian shareholders. The Belgian government complained on the basis that Spain had allowed this to happen, thereby denying justice to the shareholders and violating international law. The ICJ stated:

"When a State admits into its territory foreign investments or foreign nationals, whether natural or juristic persons, it is bound to extend to them the protection of the law and assumes obligations concerning the treatment to be afforded them. These obligations, however, are neither absolute nor unqualified. In particular, an essential distinction should be drawn between the obligations of a State towards the international community as a whole, and those arising vis-à-vis another State in the field of diplomatic protection. By their very nature the former are the concern of all States. In view of the importance of the rights involved, all States can be held to have a legal interest in their protection; they are obligations erga omnes.

Such obligations derive, for example, in contemporary international law, from the outlawing of acts of aggression, and of genocide, as also from the principles and rules concerning the basic rights of the human person, including protection from slavery and racial discrimination. Some of the corresponding rights of protection have entered into

\footnotetext{
${ }^{43}$ Draft Articles on the Law of Treaties with Commentaries [1966] Yearbook of the International Law Commission, ii, at 248 (UN Doc A/CN.4/SER.A/1966/Add. 1).

${ }^{44}$ S. Griller, 'International Law, Human Rights and the European Community's Autonomous Legal Order: Notes on the European Court of Justice Decision in Kadi' (2008) 4(3) ECLR 528-553, 530.

${ }^{45}$ Barcelona Traction, Light and Power Company, Limited (Belgium v. Spain), Second Phase, Judgment of 5 Feb. 1970 [1970] ICJ Rep 3
} 
the body of general international law others are conferred by international instruments of a universal or quasi-universal character" 46 .

This is echoed in human rights instruments, for example, the ECHR in Article 15 prohibits any derogation, even in time of war, from the prohibition of torture and inhuman treatment (Article 3), the prohibition of slavery and servitude (Article 4), and the prohibition of punishment without law (Article 7).

According to Bianchi, the relationship between jus cogens and human rights is intrinsic since peremptory norms aim to materialise as powerful collective beliefs. ${ }^{47}$ As it is seen in the Barcelona Traction decision, jus cogens have the effect of generating obligations erga omnes, which are obligations owed to the international community as a whole. ${ }^{48}$ Indeed, a more historical version of jus cogens provided that any treaty which would in effect lead a State to not protecting adequately the liberty, honour of property of people in its territory should have been forbidden in international law. ${ }^{49}$

Obligations erga omnes as per the judgment in Barcelona Traction are obligations regarding the protection of rights that every state has an interest in protecting. Such obligations are therefore owed to the international community as a whole; this forms a system of protection of "aggravated responsibility" for the violation of the norms that are deemed to be of particular importance. ${ }^{50}$ The obligations include the protection of certain human rights, as mentioned in the Human Rights Committee General Comment $31^{51}$ where it was stated that:

"This follows from the fact that the 'rules concerning the basic rights of the human person' are erga omnes obligations and that, as indicated in the fourth preambular paragraph of the Covenant, there is a United Nations Charter obligation to promote universal respect for, and observance of, human rights and fundamental freedoms"

\footnotetext{
46 Ibid.

${ }^{47}$ A. Bianchi, 'Human Rights and the Magic of Jus Cogens' (2008) 19 EJIL 491- 508, 492.

${ }^{48}$ Barcelona Traction, Light and Power Company, Limited (Belgium v. Spain), Second Phase, Judgment of 5 Feb. 1970 [1970] ICJ Rep 3, at 32, para. 34.

49 Von Verdross, 'Forbidden Treaties in International Law', (1937) 31 AJIL 571, at 574.

50 [1976] Yearbook of the International Law Commission, II (Part Two), at 95.

51 UN Human Rights Committee (HRC), General comment no. 31 [80], The nature of the general legal obligation imposed on States Parties to the Covenant, 26 May 2004, CCPR/C/21/Rev.1/Add.13
} 
The relationship of the EU with peremptory norms became the subject of discussion in the Kadi litigation, where the case involved an action for annulment of an EU Regulation that implemented a Security Council Resolution freezing the funds of persons suspected of cooperation with terrorists. When the first case reached the CFI in 2005 the court stated the following:

"None the less, the Court is empowered to check, indirectly, the lawfulness of the resolutions of the Security Council in question with regard to jus cogens, understood as a body of higher rules of public international law binding on all subjects of international law, including the bodies of the United Nations, and from which no derogation is possible" 52

The CFI's position was that it had jurisdiction for indirect review of Security Council Resolutions through the review of EU acts adopting them, and in many of its references to jus cogens, it stated that peremptory norms include mandatory prescriptions concerning the universal protection of the rights of the human person and that jus cogens is a source of fundamental rights. The CFI's stance was that where the Resolution would conflict with jus cogens, it would not bind the EU.

The CFI in $\mathrm{Kadi}^{53}$ actually hinted that the right to property in these peremptory norms, as its arbitrary deprivation could potentially be regarded as contrary to jus cogens:

"In addition, in so far as respect for the right to property must be regarded as forming part of the mandatory rules of general international law, it is only an arbitrary deprivation of that right that might, in any case, be regarded as contrary to jus cogens. Such is not the case here."

This extension of the rights protected by jus cogens has been criticised heavily as unusual, curious and overly extensive, due to the fact that jus cogens is an area of law which is narrow but yet unclearly defined. ${ }^{54}$

\footnotetext{
${ }^{52}$ Case T-306/01 Yusuf and Al Barakaat International Foundation v. Council and Commission [2005] ECR II-3533; Case T-315/01 Kadi v. Council and Commission [2005] ECR II-3649 §276-277.

${ }^{53}$ Ibid.
} 
Upon appeal, ${ }^{55}$ the Court of Justice rejected the CFI's position that the EU judicial system had jurisdiction to indirectly review an international act even if that contradicted jus cogens. Therefore, while the ECJ agreed that the Union would not be bound to give effects to acts violating jus $\operatorname{cogens}^{56}$ it denied that it had any jurisdiction to review directly or indirectly international measures, stating that it is not for the Community judicature to review such measures even where such review would be limited to the compatibility of the act with jus cogens. ${ }^{57}$

Instead it favoured a review which emphasises the 'municipal' constitutional nature of EU law, ${ }^{58}$ and provided that the Union courts have jurisdiction to rule on the validity of the EU measure with higher rules of law that are found within the EU legal order and stated:

"288...any judgment given by the Community judicature deciding that a Community measure intended to give effect to such a resolution is contrary to a higher rule of law in the Community legal order would not entail any challenge to the primacy of that resolution in international law.....

300. What is more, such immunity from jurisdiction for a Community measure like the contested regulation, as a corollary of the principle of the primacy at the level of international law of obligations under the Charter of the United Nations, especially those relating to the implementation of resolutions of the Security Council adopted under Chapter VII of the Charter, cannot find a basis in the EC Treaty....

305. Nor can an immunity from jurisdiction for the contested regulation with regard to the review of its compatibility with fundamental rights, arising from the alleged absolute primacy of the resolutions of the Security Council to which that measure is designed to give effect, find any basis in the place that obligations under the Charter of the United

\footnotetext{
${ }^{54}$ P. Eeckhout, Community Terrorism Listings, supra note 75; C. Tomuschat, 'Note on Kadi' (2005) CMLRev 537.

55 Joined Cases C-402/05 P and C-415/05 P Kadi and Al Barakaat International Foundation v. Council [2008] ECR I-6351.

${ }^{56} \mathrm{cf}$. van Vooren and Wessel (n.27), 237.

${ }^{57}$ cf. Kadi and Al Barakaat (n.55) §287.

${ }^{58}$ G. de Búrca, 'The European Court of Justice and the International Legal Order After Kadi', (2009) 51(1) Harv ILJ $1,29$.
} 
Nations would occupy in the hierarchy of norms within the Community legal order if those obligations were to be classified in that hierarchy....

321. In any event, the existence, within that United Nations system, of the reexamination procedure before the Sanctions Committee, even having regard to the amendments recently made to it, cannot give rise to generalised immunity from jurisdiction within the internal legal order of the Community."

The ECJ stated that the jurisdiction existed in respect of the internal measure, of which the legality may be tested against the EU's higher rules of law, which included fundamental rights. The ECJ also took a different position than the CFI, regarding the content of jus cogens and state that a norm may be classified as jus cogens only when no derogation from it is possible. The ECJ's position was that the rights invoked in the cases in question - the right to a fair hearing and the right to respect for property - are, however, subject to limitations and exceptions.

While the ECJ did not undermine the importance of jus cogens or the fact that the EU ought to respect the international legal order, it has been observed by De Búrca, that the ECJ's view on the relationship between EU law and international law was a 'horizontal and segregated one' where there is no communication between the two legal orders that exist in parallel to each other. $^{59}$

Therefore, the CJEU's position in Kadi seems, if not contrary to the previous statements of the CJEU in Racke ${ }^{60}$, Opel Austria ${ }^{61}$ to sit uneasily with the recognition of customary international law as a rule binding the Union. A position taken by Giannelli is that when Kadi was ruled in 2008 the provisions in Articles 3 and 21 TEU which provide for the respect and promotion of international law did not yet exist, and that both primary and secondary law may deviate from international law to regulate the relationship with and between its member states unless we are

\footnotetext{
${ }^{59}$ Ibid, 29.

${ }^{60}$ Case C-162/96 Racke GmbH v. Haptzollamt Mainz [1998] ECR I-3655 §§45-46.

${ }^{61}$ cf. Opel Austria (n.36).
} 
dealing with jus cogens. ${ }^{62}$ Gianelli's position is that the duty to respect international law today amounts to a constitutional principle of the EU. ${ }^{63}$

A couple of years after $\mathrm{Kadi}^{64}$, in Air Transport Association of America ${ }^{65}$, in 2010 the CJEU made certain important deliberations. It considered that it has no jurisdiction or competence to examine the validity of EU legislative action in the light of international law when the EU is not bound by a convention. However, it made a clear statement that the EU is bound by customary international law:

"101. Under Article 3(5) TEU, the European Union is to contribute to the strict observance and the development of international law. Consequently, when it adopts an act, it is bound to observe international law in its entirety, including customary international law, which is binding upon the institutions of the European Union"

In this decision, the CJEU made reference to Poulsen ${ }^{66}$ and Racke ${ }^{67}$. In Poulsen, the ECJ had made a laconic observation that the Union must respect international law in the exercise of its powers and that therefore any EU measure must be interpreted in the light of the relevant international law rules. In Racke, the CJEU held that when legislating, the EU must comply with the rules of international law which are binding on the Union institutions and which form part of the Union legal order.

\section{F. Conclusions}

The answer to the theoretical question of whether the EU may breach international human rights obligations is that the EU could only possibly breach its international human rights obligations arising out of jus cogens.

Firstly, the EU is not formally bound by an international legal instrument which provides for a comprehensive and wide protection of human rights. It has limited this to acceding to

\footnotetext{
${ }^{62}$ A. Gianelli 'Customary International Law in the European Union', in E. Cannizzaro, P. Palchetti and Wessel (eds.) International Law as Law of the European Union (Brill 2011) 99-105.

${ }^{63}$ Ibid.

${ }^{64}$ cf. Kadi I (n.55).

${ }^{65}$ Case C-366/10 Air Transport Association of America and Others ECLI:EU:C:2011:864.

${ }^{66}$ Case C-86/90 Poulsen and Diva Navigation [1992] ECR I-6019 §§9-10.

${ }^{67}$ cf. Racke (n.60).
} 
conventions with a more specific subject matter such as the Convention on the Rights of Persons with Disabilities and other instruments that protect human rights within the sphere of a more specific or different subject matter. The EU therefore follows a selective adherence to human rights-related conventions.

The attempt to accede to the European Convention on Human Rights came to a halt by Opinion 2/13, marking a failure of the EU to integrate an international human rights instrument into its internal law and to harmonise EU law with the possibility of international human rights obligations. This left the EU in a limbo in terms of fulfilling its obligations according to Article 6(2) TEU, while it exposes EU activity to indirect review. ${ }^{68}$ Even if that were the case, the CJEU has demonstrated reluctance to afford direct effect within EU law of provisions relating to human rights, stemming from other international legal instruments that it has actually acceded to. ${ }^{69}$

Secondly, it is deduced that despite the perhaps confusing statements of both the $\mathrm{CFI}^{70}$ and the $\mathrm{CJEU}^{71}$ in the Kadi litigation regarding the international human rights responsibility of the EU, as well as the nature and extent of jus cogens, the post-Lisbon Union seems to have made unequivocal statements of respect for international law both in its primary law provisions and the post-Lisbon jurisprudence, such as the judgment in $A T A A .^{72}$ What is thus far clear is that the Union is bound by the minimum standard of human rights obligations that has so far been accepted to be guaranteed by peremptory norms.

Therefore, it becomes evident that the EU has no express or binding international obligation to respect human rights beyond the ones guaranteed by peremptory norms which include the prevention of racial discrimination, the prohibition of torture, slavery, aggression and genocide. ${ }^{73}$ This is not without significance, given that the assumption that the EU is bound by jus cogens generates obligations to respect these rules, owed to the international community as a whole. ${ }^{74}$

\footnotetext{
${ }^{68}$ cf. Bosphoros (n.30).

${ }^{69}$ Case C-363/12 Z v. A Government Department EU:C:2014:159.

${ }^{70}$ cf. Kadi I (CFI) (n.52).

${ }^{71}$ cf. Kadi I (n.55).

72 cf. ATAA (n.65).

73 cf. Barcelona Traction (n.48).

74 cf. General Comment No. 31 (n.51).
} 
Nevertheless, the EU is not formally bound to respect a wide range of human rights by virtue of international law, and for all individuals. For example, the right to private life, the right to property, the freedom of association do not belong to the norms that fall under the umbrella of jus cogens at an international level, neither are they protected in themselves by the few international instruments the EU has signed that deal with specific areas and rights. The EU's international obligations as regards these remain, at least from an international law viewpoint, unclear.

Despite the fact that the Charter of Fundamental Rights includes the abovementioned ${ }^{75}$ (and many other) rights, such qualified rights are not part of customary international law. Therefore, the internal recognition of certain human or fundamental rights by Union law does not guarantee that the Union is accountable for their violations on the international plane, leaving an important void in the substantive protection of human rights against arbitrary Union action within the area of international law.

${ }^{75}$ Article 7 of the EU Charter protects the right to private and family life; Article 17 of the EU Charter guarantees the right to property; Article 12 guarantees the freedom of assembly and association. 


\section{Chapter 11}

\section{The EU and the Doctrine of Attribution in International Law}

\section{A. Introduction}

International organisations play an important role where there are conflicts, as states may submit their military to international organisations in order to effect peace-keeping operations. This has given rise to the question of attribution - where action is taken by subjects of one state under the orders of the international organisation, it must be determined whether that action is to be attributed to one (or more than one) state or the international organisation.

As it was discussed in Chapter 10, immediately above, the EU may breach human rights obligations deriving from jus cogens, which is applicable universally. If those obligations are found to apply to the EU, then the next matter to be ascertained, is how the EU's responsibility could be engaged. In international law, international responsibility is determined on the basis of the doctrine of attribution.

This Chapter will begin by outlining the development of the doctrine of attribution of public international law (Section B). Then this Chapter shall examine how the doctrine of attribution applies to international organisations (Section C) and how the case law on this matter relates to the EU (Section D) before making some observations on the applicability of this doctrine to the EU.

\section{B. The doctrine of attribution in public international law}

Attribution in public international law is regarded a pre-requisite for the engagement of international responsibility, ${ }^{1}$ with the rationale that no legal person may act without the conduct of a natural person. ${ }^{2}$ The ICJ had recognised in its decision in Difference Relating to Immunity

\footnotetext{
${ }^{1}$ J. Griebel and M. Plücken, 'New developments regarding the rules of attribution? The International Court of Justice's decision in Bosnia v Serbia' (2008) 21(3) Leiden Journal of International Law 601, 602.

${ }^{2}$ See L. Condorelli, 'L'imputation à l'état d'un fait internationalement illicite: solutions classiques et nouvelles tendances', (1984/VI) 189 RCADI 19; C. Kress, 'L'organe de facto en droit international public - réflexions sur l'imputation à l'état de l'acte d'un particulier à la lumière des développements récents', (2001) 105 Revue Générale de Droit International Public 93.
} 
from Legal Process of a Special Rapporteur of the Commission on Human Rights ${ }^{3}$, much earlier than the issuance of any of either the ILC Articles or the ARIO, that it is a customary law rule that the conduct of any organ of a state must be regarded as an act of that state.

Attributable conduct may include both action and inaction by either a state or an international organisation, therefore omissions may also generate international legal responsibility. ${ }^{4}$ It is common practice for states and international organisations to have delegations and to instruct persons or bodies to act, or even to delegate some of their powers to those persons or bodies while the central authorities give no specific instructions as to how to act. Beyond the EU's obvious examples under the CFSP/CSDP policy, examples include military operations, and such cases have arisen in the area of Former Yugoslavia. ${ }^{5}$ The doctrine of attribution or attributability is a necessity that arises out of this delegation of powers in order to identify who is the ultimate defendant that will be held responsible for the violation of international law.

Where the person committing the act has no status of an 'organ' granted, as per the Immunity from Legal Process case, ${ }^{6}$ then the next question is whether the relevant person or entity may be equated to an organ of that state. According to the ICJ the criterion for establishing this is the one of 'complete dependency' of that person or entity to the state. ${ }^{7}$

Where the conduct is perpetrated by a person or entity which is not an organ of the relevant state and where no 'complete dependency' can be shown, Article 8 of the ILC Articles provides for two scenarios: one is where the person or entity is acting under the instructions of the state, and the other when it is acting under the control or directions of the state.

\footnotetext{
${ }^{3}$ Adopted Yearbook of the International Law Commission (1956) Vol. II, p. 225.

${ }^{4}$ Regarding state responsibility a relevant decision of the ICJ is United States Diplomatic and Consular Staff in Tehran, while for international organisations a relevant authority would be the ICJ's decision in Difference Relating to Immunity from Legal Process of a Special Rapporteur of the Commission on Human Rights, ICJ Reports 1999, pp. 88-89, para. 66.

${ }^{5}$ See for example, Application of the Convention on the Prevention and Punishment of the Crime of Genocide (Bosnia and Herzegovina v.Serbia and Montenegro), Judgment of the ICJ, 26 February 2007 (hereinafter Bosnia v. Serbia case).

${ }^{6}$ cf. (n.3).

7 Application of the Convention on the Prevention and Punishment of the Crime of Genocide (Bosnia and Herzegovina v. Serbia and Montenegro), Judgment of the ICJ 26 February 2007, Military and Paramilitary Activities in and against Nicaragua [1986] ICJ Reports 14.
} 
According to the Commentary to the Articles, the first scenario is a more specific one (i.e. specific instructions are given) and the second is a more general scenario where the persons are under the control of the State but not acting with specific directions.

Such a possibility makes things more complicated, not only due to the existence of discretion inherent in the conduct at stake, but given that certain persons, beyond the state's officials involved may not be employed officials of the state but 'auxiliaries'. ${ }^{8}$ These persons may be considered de facto organs or agents of the state or international organisation, as opposed to de jure ones, who are legally or officially linked to it.

In Military and Paramilitary Activities in and against Nicaragua ${ }^{9}$ the ICJ laid down its rule regarding attribution when it is not clear to whom the conduct is attributable.

"All the forms of United States participation mentioned above, and even the general control by the respondent State over a force with a high degree of dependency on it, would not in themselves mean, without further evidence, that the United States directed or enforced the perpetration of the acts contrary to human rights and humanitarian law alleged by the applicant State. Such acts could well be committed by members of the contras without the control of the United States. For this conduct to give rise to legal responsibility of the United States, it would in principle have to be proved that that State had effective control of the military or paramilitary operations in the course of which the alleged violations were committed."

From this it is deduced that wether the conduct is attributed to a state depends on whether the State in question has effective control over the said conduct. This approach taken by the ICJ is not the only one which exists in international legal fora in terms of determining attribution. A case that should be discussed within this framework is the decision of the International Criminal Tribunal for Former Yugoslavia in Tadic..$^{10}$

\footnotetext{
8 Draft Articles on the Responsibility of States for Internationally Wrongful Acts, with CommentariesYearbook of the International Law Commission, 2001, vol. II, Part Two, p. 47.

9 [1986] ICJ Rep 14.

${ }^{10}$ Prosecutor v. Duško Tadić, International Tribunal for the Former Yugoslavia, Case IT-94-1-A (1999), ILM vol. 38, No. 6 (November 1999), p. 1518, at p. 1541, para. 117
} 
During the dissolution of the Socialist Federal Republic of Yugoslavia, an entity called the Serb Republic of Bosnia and Herzegovina was formed in the Serb-controlled area of Bosnia and Herzegovina. In May 1992, the Bosnian Serb Armed Forces (VRS) were formed and by virtue of a UN Security Council Resolution the Socialist Federal Republic of Yugoslavia (SFRY) withdrew its armed forces from Bosnia. Nevertheless, the SFRY's armed forces (known as JNA) remained in control of the VRS. The accused in this case was a Serb nationalist, who advocated ethnic cleansing and following this involvement in local politics, committed atrocities in detention camps where prisoners were held by the VRS.

The ICTY had to determine whether the victims of the accused, were in the hands of a party in the armed conflict of which they were not nationals. In this case the JNA was controlling the VRS - that would constitute the VRS a de facto organ of the SFRY. If so, this relationship would 'internationalise' the conflict and the accused would be charged with 'grave breaches' of the Geneva Conventions. ${ }^{11}$

The case was adjudicated both at a trial and an appeal level. The Trial Chamber of the ICTY held that in order to make such a finding there should have been effective control of the VRS by the JNA. ${ }^{12}$ This was met by intensive criticism by the presiding judge McDonald who delivered a dissenting judgment stating the following:

"I find that the majority's requirement of effective control for making a determination of agency is founded on a misreading of the findings in Nicaragua and a misapplication of those findings to the facts of the case before the Trial Chamber. I would conclude that the effective control standard was never intended to describe the degree of proof necessary for a determination of agency founded on dependency and control as articulated in paragraph 109 of Nicaragua. However, if Nicaragua did set the standard of proof required for agency as that of effective control, that finding should be limited to the specific facts of that case and is not applicable to the issues presented to the Trial Chamber. In considering whether the victims of the accused were protected persons at the

\footnotetext{
${ }^{11}$ R.J. Goldston, R. Hamilton, 'Bosnia v Serbia: lessons from the encounter of the International Court of Justice with the International Criminal Tribunal for the Former Yugoslavia', (2008) 21(1) Leiden Journal of International Law 95-112, 99.

${ }^{12}$ para 605 of the Trial Chamber Judgment.
} 
times relevant to the Indictment, the majority states that, upon redesignation of the JNA in Bosnia and Herzegovina as the VRS, the key question was whether the requisite degree of command and control by the VJ, and hence the Federal Republic of Yugoslavia (Serbia and Montenegro), over the VRS is established for the purposes of imputing the acts of those forces operating in opstina Prijedor or the VRS as a whole to the Federal Republic of Yugoslavia (Serbia and Montenegro)."

Therefore, the opinion of judge McDonald was that the effective control standard is not the primary test for attribution but it is used in cases where no complete dependency can be established. $^{13}$

Upon appeal, the appeals chamber of the ICTY, found the Nicaragua ${ }^{14}$ test inapplicable but also dismissed the view of judge McDonald. The Appeals Chamber took a different viewpoint saying that the degree of 'control' needed for attribution depends on the facts of each case. At first it stated that the effective control test is at odds with state practice, because such practice has provided for attribution at a lower standard of control. ${ }^{15}$ The ICTY made reference to several international cases such as Loizidou $v$. Turkey, ${ }^{16}$ where 'overall effective control over the authorities' was found to be sufficient and the Iran Revolutionaries case ${ }^{17}$ where the question was whether the groups were acting on behalf of Iran.

The ICTY stated that where the conduct in question is committed by individuals or militarily unorganised groups, the standard of attribution is whether there have been given specific instructions by the state, or endorsed or approved by the state ex post facto. ${ }^{18}$ Where the conduct in question has been committed by an organised military group, the standard of attribution of that conduct to a state would be 'overall control' over those forces. ${ }^{19}$ It added that international law does not only have one test of overall control for armed groups and of specific instructions for

\footnotetext{
13 cf. Goldston and Hamilton (n.11) 100.

14 cf. (n.9).

15 Para 124 of the Judgment "The "effective control" test propounded by the International Court of Justice as an exclusive and all-embracing test is at variance with international judicial and State practice: such practice has envisaged State responsibility in circumstances where a lower degree of control than that demanded by the Nicaragua test was exercised."

${ }^{16}$ Loizidou v. Turkey (Preliminary Objections) (App no. 16318/89) ECtHR 24 October 1995 (1995) 20 EHRR 99.

${ }^{17}$ Kenneth P. Yeager v. Islamic Republic of Iran (1987) 17 Iran-U.S. Claims Tribunal Reports, vol. IV, p.92.

18 cf. Prosecutor v. Duško Tadić (n.10) paragraph 137.

${ }^{19}$ Ibid, paragraph 138.
} 
individuals or militarily unorganised groups but that there is also a third test of assimilation of individuals to State organs on account of their actual behaviour within the structure of a State.

This approach taken by the ICTY has been subject to criticism as to its evaluation of the Nicaragua test. ${ }^{20}$ The judgment has been characterised as aggressive and in violation of the principle of judicial economy because the ICTY's criticism exceeded the necessary analysis required for the delivery of the judgment on the particular facts. ${ }^{21}$ The ILC Articles on State Responsibility Commentary distinguishes this judgment from the general trend, since the ICTY deals with international criminal cases and it is not within its material jurisdiction to rule on state responsibility. ${ }^{22}$

In Bosnia v. Serbia and Montenegro, ${ }^{23}$ the ICJ reiterated its Nicaragua approach and made some reference to the judgment of the ICTY in Tadić. This case involved the massacre which was committed in the city of Srebrenica. In its judgment on genocide in Bosnia, the International Court of Justice (ICJ), after finding that the Bosnian Serb armed forces (VRS) had perpetrated genocide in Srebrenica, had to determine whether those armed forces had acted on behalf of the Federal Republic of Yugoslavia in which case responsibility for genocide would have to be attributed to that state.

The ICJ referred to the Tadic judgment and the 'overall control' test which was laid down by the ICTY. The ICJ first mentioned that the overall control test may have been applicable within the context of the Tadic case, but that it cannot be accepted, as the ICTY proposed, as a general test for establishing state responsibility, because it would broaden the scope of state responsibility and stated:

"405. It should first be observed that logic does not require the same test to be adopted in resolving the two issues, which are very different in nature : the degree and nature of a State's involvement in an armed conflict on another State's territory which is required for

20 M. C. Bassiouni, 'The Normative Framework of International Humanitarian Law: Overlaps, Gaps and Ambiguities,' (1998) 8 Transnational Law and Contemporary Problems 199, at 226-7; M. Sassòli and G. Olson, 'International Decision: Prosecutor v. Tadić', (2000) 94 AJIL 571 at 578

${ }^{21}$ cf. Goldston and Hamilton (n.11) 101.

${ }^{22}$ Adopted Yearbook of the International Law Commission 2001, vol. II (Part Two), p. 48.

${ }^{23}$ cf. Bosnia v. Serbia (n.5). 
the conflict to be characterized as international, can very well, and without logical inconsistency, differ from the degree and nature of involvement required to give rise to that State's responsibility for a specific act committed in the course of the conflict.

406. It must next be noted that the "overall control" test has the major drawback of broadening the scope of State responsibility well beyond the fundamental principle governing the law of international responsibility : a State is responsible only for its own conduct, that is to say the conduct of persons acting, on whatever basis, on its behalf. That is true of acts carried out by its official organs, and also by persons or entities which are not formally recognised as official organs under internal law but which must nevertheless be equated with State organs because they are in a relationship of complete dependence on the State."

Therefore, the ICJ's viewpoint was that there was room for the ICTY's interpretation within the context of the facts before it although it cannot be accepted as a general rule. The ICJ applied the Nicaragua test which it understood to be the general rule for attribution.

This analysis of the development of the doctrine of attribution in state responsibility is highly relevant to the EU's international legal responsibility. First of all, the EU has a complex structure where it uses personnel from many states to be sent abroad on its behalf. Secondly, as the European Union is an international organisation the more relevant piece of soft law applicable to it are the ARIO, which generally follow the trends in the corresponding provisions of the ILC Articles.

Further case law of international tribunals in relation to the more topical question of attribution of conduct within the context of action of an international organisation will be explored and analysed in Section D below.

\section{The criteria for holding the EU responsible as an international organisation}

As it has been analysed above, the EU's actions in the framework of the CFSP/CSDP may touch upon sensitive issues of human rights and humanitarian law. It is also possible for internal Union action to restrict human rights. It is therefore useful to look into the EU's potential international 
responsibility in the light of the Articles on the Responsibility of International Organisations. These Articles are of importance in relation to the EU, also since the European Commission actively participated in the debate on them. ${ }^{24}$

In order to hold the EU internationally legally responsible for a breach of international law two things need to occur, as it has been mentioned above. Firstly, that the conduct in question is attributable to the European Union and secondly that there is a rule of international human rights law such as a treaty or a norm of customary international law which binds the Union while it is acting.

In the case of CFSP and CSDP policies and acts, it is useful to refer to Article 3 ARIO which states that every internationally wrongful act of an international organisation entails the international responsibility of that organisation.

Article 4(2) ARIO requires that the act in question must be attributable to that international organisation and that it constitutes a breach of an international obligation of that organisation. This particular section deals with the first requirement of Article 4(2), the question of attribution. The International Law Commission's Commentary on the ARIO states that acts which can be attributed may be either positive acts or omissions. ${ }^{25}$

The general rules on attribution, developed within the framework of state responsibility have been explained above. The doctrine of attribution, for states and international organisations alike, deals with the attribution of conduct and not of responsibility. What matters is whether the act in question can be attributed to the relevant international organisation. ${ }^{26}$ The commentary on the articles also mentions that some of the practice related to the attribution of conduct relates to the context of civil liability - but this is useful in order to understand the rules of attribution. The commentary does not however mention which practice that may be.

The ARIO and the Commentary on ARIO also deal with the possibility of engaging the responsibility of an international organisation through the acts of entities that are subsidiary or

\footnotetext{
${ }^{24}$ B. van Vooren and R. Wessel, EU External Relations Law, Text, Cases and Materials (CUP 2014), 430.

25 Draft articles on the responsibility of international organizations, with commentaries (2011) Adopted Yearbook of the International Law Commission (2011) vol. II, Part Two, 14.

${ }^{26}$ Ibid, p. 16
} 
subordinate to that organisation. Article 6 (1) ARIO states that an act of an 'organ or agent' of the international organisation is considered an act of the organisation in international law, irrespective of the position of the organ or agent within the organisation. According to Article 6 of the ARIO, the conduct of an organ or agent of an international organisation in the performance of functions shall be considered as an act of that organisation irrespective of the position of that organ or agent in the organisation. The ICJ had stated in terms of agents of international organisations that:

"The Court understands the word 'agent' in the most liberal sense, that is to say, any person who, whether a paid official or not, and whether permanently employed or not, has been charged by an organ of the organisation with carrying out, or helping to carry out, one of its functions - in short, any person through whom it acts." ${ }^{27}$

This is indeed important in the context of the EU's institutions and also CFSP actions. Certain commentators suggest that while the EU through the Council is competent to establish military operations as its subsidiary organs, none of the legal acts of the Council state that military operations are subsidiary organs, and that therefore they are not de jure organs of the EU. ${ }^{28}$

The position that the expression 'bodies, offices and agencies' refers to all authorities set up under the Treaty or secondary legislation..$^{29}$ It does not necessarily cover persons involved in the operation themselves, since the operation is not set up by primary law or a legislative action. The Political and Security Committee which directs operations may fall under this definition. ${ }^{30}$

It must be emphasised nevertheless, that even in situations where the person acting is not considered an official of the relevant international organisation, the action of that person may still be attributed to the organisation where the action is taken on behalf and at the request of the

\footnotetext{
${ }^{27}$ Reparation for injuries suffered in the service of the United Nations, ICJ Reports 1949, p. 177

${ }^{28} \mathrm{cf}$. van Vooren and Wessel (n.24), 430

${ }^{29}$ Hoffmeister F., Litigating against the European Union and its Member States - who responds under the ILC's Draft Articles on international responsibility of international organizations?' (2010) 21(1) EJIL. 723-747, 740.

${ }^{30}$ E. Papastavridis, 'EUNAVFOR Operation Atlanta off Somalia: the EU in unchartered legal waters?' (2015) 64(3) ICLQ 533-568, 539, See also F. Naert, International Law Aspects of the EU's Security and Defence Policy (Intersentia 2010)
} 
organisation. ${ }^{31}$ As it was discussed above, non-officials, or de facto organs, according to the ICJ's viewpoint in Bosnia v. Serbia, ${ }^{32}$ could be subject to a different test of 'complete dependency'. Whether the test for attribution for international organisations should be different to the one used for states is something which has so far not been dealt within international case law; but so far the trends for state responsibility seem to apply in international organisation responsibility as well, therefore the complete dependence test may also be applicable to EU operations.

Article 7 ARIO deals with an issue highly relevant to CSDP operations - the possibility of secondment of personnel from States to international organisations. It provides that where an organ or agent of a state or another international organisation is placed at the disposal of another international organisation, then the act of such organ or agent shall be considered under international law an act of the latter organisation if the organisation exercises effective control over that conduct.

\section{Case law on attribution and the EU}

So far, discussion has centred on certain soft law provisions that underpin the notion of international responsibility for states and international organisations. In order to have a better understanding of these principles, it is necessary to look into judicial decisions, where the issue of attribution of an act to an international organisation has arisen and how this could be potentially related to the European Union vis-à-vis conventional or customary law human rights obligations.

Two important authorities as to the question of the responsibility of the Union as an international organisation are the decisions of the European Court of Human Rights in Behrami and Behrami v. France and in Saramati v. France, Germany and Norway. ${ }^{33}$ These two complaints regarded the situation in Kosovo. The United Nations' Security Council had passed Resolution 1244 that established a security presence in Kosovo (KFOR) which was set up by the Member States and

${ }^{31}$ G. Gaja, 'Articles on the Responsibility of International Organisations' United Nations Audiovisual Library of International Law, 3 http://legal.un.org/avl/pdf/ha/ario/ario e.pdf, 5.

${ }^{32}$ cf. (n.5).

${ }^{33}$ Behrami and Behrami v. France, (App. No 741412/01) ECtHR 2 May 2007 [GC] (2007) 45 EHRR SE10 Saramati v. France, Germany and Norway (App. No. 78166/01) ECtHR 2 May 2007 [GC] (2007) 45 EHRR SE10. 
other institutions under the UN auspices and also an interim administration of Kosovo (UNMIK), also under UN auspices.

The question of whether the UN could be responsible for the actions of its agencies appeared where two of Mr Behrami's sons were wounded by an undetonated bomb, resulting in one of them dying and the other becoming permanently blind. This application was therefore relevant to the breach of the right to life under Article 2 of the European Convention. In the second application, Mr Saramati was extra-judicially arrested by the KFOR and filed a claim against the respondent states for breaching his right to liberty and security under Article 5 of the Convention, his right to an effective remedy under Article 13 of the Convention, his right to access to a court under Article 6(1) of the Convention and the obligation of the respondent states to respect their Convention obligations in Kosovo.

What is important in these decisions is that both claims were dismissed as inadmissible, and the Court held that it had no jurisdiction ratione personae in the sense that the applications were not brought against the correct legal person. The applications were directed against the several states participating in the operations, whereas it was held that the action was attributable to the United Nations. Both applications were considered in a single judgment in which the ECtHR held that "that the key question is whether the UNSC retained ultimate authority and control so that operational command only was delegated." In terms of the UNMIK, the Court held that it was a subsidiary organ of the Secretary General of the United Nations' Security Council. In terms of the security forces, the Court held that the powers were delegated by the UNSC to the Member States (and therefore the final authority remained with the UNSC) and that the delegation of the powers was explicitly provided for in the Resolution which also put sufficiently defined limits.

Returning to the case of the EU, it is necessary to compare and contrast the example in Behrami and Saramati with potential equivalents in the EU context. Indeed, action taken under the CSDP headed by the EU is to be controlled by the EU (or its bodies) and the Member States do not appear to have any control in the direction of the relevant act. This is encountered in CSDP Decisions. 
Relevant case law as to bodies under the control of an international organisation also exists in the ICJ's decisions. In relation to the question of 'organs or agents' the Commentary on the ARIO makes reference to the jurisprudence of the International Court of Justice (ICJ) on this matter, and state that the Court has found attribution where the person has no official status. ${ }^{34}$ Therefore, taking this view point, the fact that the legal person acting is not considered a de jure organ of the Union as it has been explained above, does not exclude attribution and therefore does not exclude the Union's (or any other international organisation's) responsibility.

More specifically, the Commentary makes reference to the ICJ's decision in Reparation for injuries suffered in the service of the United Nations. The Court noted that the question addressed by the General Assembly concerned the capacity of the United Nations to bring a claim in case of injury caused to one of its agents and said:

'The Court understands the word 'agent' in the most liberal sense, that is to say, any person who, whether a paid official or not, and whether permanently employed or not, has been charged by an organ of the organisation with carrying out, or helping to carry out, one of its functions - in short, any person through whom it acts." 35

The ICJ has also held in Applicability of article VI, section 22, of the Convention on the Privileges and Immunities of the United Nations ${ }^{36}$ that what matters is not the rank or administrative position of the relevant organ or agent but rather the nature of its mission.

It is also a possibility that the person, organ or agent's act is a conduct attributed jointly to the international organisation as well as the state which places that person, organ or agent at the disposal of the international organisation. This was held in the decisions of the Hague Court of Appeal regarding the Dutch forces' conduct in Srebrenica, in Bosnia. ${ }^{37}$

${ }^{34}$ cf. ARIO Commentary (n.25), p. 17

${ }^{35}$ Reparation for injuries suffered in the service of the United Nations ICJ Reports 1949, 177

${ }^{36}$ ICJ Reports 1989, 194, §47

${ }^{37}$ Hasan Nuhanovič v. the Netherlands, Court of Appeal in The Hague, Civil Law Section (5 July 2011), LJN: BR5388;200.020.174/01; ILDC 1742 (NL 2011), English translation available athttp://zoeken.rechtspraak.nl/detailpage.aspx?ljn=BR5388, Mehida Mustafič-Mujič, DamirMustafič, and Alma Mustafič v. the Netherlands, Court of Appeal in The Hague, Civil Law Section (5 July 2011), LJN:BR5386; 200.020.173/01, English translation available at http://zoeken.rechtspraak.nl/detailpage.aspx?ljn=BR5386. 
In these cases, the Dutch Battalion for Peacekeeping (Dutchbat) were participating in United Nations Protection Force (UNPROFOR) in Bosnia. The issue that arose was that Dutchbat was evacuating a compound and move personnel, and many refugees, mainly women, children and elderly people, to another place. In this process, Dutchbat had sent away several men, thus not including them in the evacuation process, although it was a real and known risk that these men would be seized and physically harmed or killed by the Bosnian Serb Army. The orders were given by Dutch officials, who were however under the umbrella of UNPROFOR.

These cases raised the issue of tortious/civil liability of the Netherlands under Bosnian law to remedy the harm caused by the action of Dutchbat. It is therefore an important case demonstrating the interplay of public international law and human rights obligations on the one hand, and the domestic legal systems of civil liability on the other. The Court of Appeal of The Hague first of all upheld the notion of effective control, which demonstrates that beyond academics this is also the criterion preferred by domestic judicial systems. ${ }^{38}$ What is however, also important is that the Court of Appeal of the Hague found that conduct may be attributed to both the international organisation and the state:

"... significance should be given to the question whether that conduct constituted the execution of a specific instruction, issued by the UN or the State, but also to the question whether, if there was no such specific instruction, the UN or the State had the power to prevent the conduct concerned.... the possibility that more than one party has "effective control" is generally accepted, which means that it cannot be ruled out that the application of this criterion results in the possibility of attribution to more than one party'

\footnotetext{
${ }^{38}$ B. Boutin, 'Responsibility of the Netherlands for the acts of Dutchbat in Nuhanovič and Mustafič: the continuous quest for a tangible meaning for "effective control" in the context of peacekeeping' (2012) 25(2) Leiden Journal of International Law 521-535, 526-527, T. Dannenbaum, 'Translating the Standard of Effective Control into a System of Effective Accountability: How Liability Should Be Apportioned for Violations of Human Rights by Member State Troop Contingents Serving as United Nations Peacekeepers', (2010) 51(1) Harv ILJ 113, 140, B. Kondoch, 'The Responsibility of Peacekeepers, Their Sending States, and International Organizations', in T. Gill and D. Fleck (eds.), The Handbook of the International Law of Military Operations (OUP 2010) 515, at 521; N. Tsagourias, 'The Responsibility of International Organisations for Military Missions', in M. Odello and P. Ryszard (eds.), International Military Missions and International Law (Brill 2011), 245, at 249, C. van Dam, The Netherlands liable towards family of Srebrenica victims, Insight American Society of International Law: https://www.asil.org/insights/volume/15/issue/27/netherlands-found-liable-srebrenica-deaths.
} 
The Court therefore found that the Netherlands were indeed exercising effective control over Dutchbat, but also opened up a new page to the possibility of joint attribution and by extent the theoretical concept joint liability. This may be an echoing of the opinion that soldiers, even where they are seconded to international organisations never fully leave their employment by the state. $^{39}$

This is, however, an important decision from another point of view as well - it is a positive approach to the tortious liability that may arise in the context of international action. It provides the link between international human rights law and domestic civil liability rules. This can be seen as filling the gap of available legal fora and remedies, which will be discussed further below in this Chapter.

\section{E. Observations on the rules on attribution and their applicability to the case of the EU}

The importance of the rules of attribution for the EU is that as the EU is an international organisation which may act only through its institutions, bodies, offices, and agencies and their servants and therefore its responsibility will be established by proving attribution. ${ }^{40}$ However, the rules of attribution for the responsibility of international organisations remain a developing area of international law, with few concrete legal sources on the matter, while the ARIO are not binding. Further, the existing rules of attribution must also be assessed as to their applicability to the EU's special identity.

Within the context of the CSDP, according to Articles 42 and 43 TEU, where the EU is launching operations, it derives civilian and military means and personnel from the capabilities of its Member States. In peacekeeping operations in the United Nations, the disciplinary power remains with the contributing state demonstrating therefore that the state retains some of its control. ${ }^{41}$ The question therefore arises, as to which are the criteria to determine whether the EU may be held internationally responsible for conduct of persons acting within the framework of its CSDP operations.

${ }^{39}$ M. Zwanenburg, Accountability of Peace Support Operations (Brill/Nijhoff2005), while the Hague Court of Appeal also stated in $\S 5.10$ that the soldiers remain employed by the State.

40 cf. Hoffmeister (n.29).

${ }^{41}$ cf. ARIO Commentary (n.25), p. 20 and Article 9 of the model contribution agreement (A/50/995, annex; A/51/967, annex). 
The above discussion has revealed the lack of clarity as to attributing the conduct of a person or an entity to a state or an international organisation. For example, the determination of whether the conduct of the organ or agent in the context of the ARIO is attributable to an international organisation depends on taking account of all the factual circumstances and the relevant context. ${ }^{42}$ According to the commentary on the ARIO, what is of importance is whether the international organisation in question has effective control over those organs or agents. ${ }^{43}$

The reasoning in Behrami and Saramati $^{44}$ is again of great importance as to the attribution of conduct to the EU. The Strasbourg Court was of the view that the question of attribution was one of 'ultimate control' therefore liberally interpreting the meaning of 'effective' to be equivalent to 'ultimate' The ECtHR, supported its opinion that attribution is determined on the basis of ultimate control of the operation on three more occasions: Kasumaj v. Greece ${ }^{45}$, in Gajić v. Germany ${ }^{46}$ and Berić and others v. Bosnia and Herzegovina. ${ }^{47}$.

It has been suggested that the notion of effectiveness should be more relevant to operational control (which the Court held was indeed delegated). ${ }^{48}$ In the context of the United Nations, the

42 cf. ARIO Commentary (n.25), p. 20

${ }^{43}$ J-P. Ritter, 'La protection diplomatique à l'égard d'une organisation internationale' (1962) 8 Annuaire Français de Droit International, 427,442, M. Pérez González, 'Les organisations internationales et le droit de la responsabilité', (1988) 92 Revue Générale de Droit International Public 63, 83; M. Hirsch The Responsibility of International Organizations toward Third Parties (Dordrecht/London: Nijhoff, 1995) 64-67; C.F. Amerasinghe Principles of the Institutional Law of International Organizations, (2nd edn, Cambridge: Cambridge University Press, 2005) 401403; P. Klein, La responsabilité des organisations internationales dans les ordres juridiques internes et en droit des gens (Bruxelles: Bruylant/Editions de l’Université de Bruxelles, 1998) 379-380.

${ }^{44}$ cf. Behrami and Saramati (n.33).

${ }^{45}$ Application No. 6974/05, ECtHR 5 July 2007 (Admissibility).

${ }^{46}$ Application No. 31446/02, ECtHR 28 August 2007 (Admissibility)

${ }^{47}$ Berić and others v. Bosnia and Herzegovina (admissibility) (Apps No. 36357/04, 36360/04, 38346/04, 41705/04, 45190/04, 45578/04, 45579/04, 45580/04, 91/05, 97/05, 100/05, 1121/05, 1123/05, 1125/05, 1129/05, 1132/05, 1133/05, 1169/05, 1172/05, 1175/05, 1177/05, 1180/05, 1185/05, 20793/05 and 25496/05) ECtHR 16 October 2007 (2001) 35 EHRR 3.

${ }^{48}$ C. Bell, 'Reassessing multiple attribution: the International Law Commission and the Behrami and Saramati decision', (2010) 42 New York University Journal of International Law and Politics, 501, P. Klein, 'Responsabilité pour les faits commis dans le cadre d'opérations de paix et étendue du pouvoir de contrôle de la Cour européenne des droits de l'homme: quelques considérations critiques sur l'arrêt Behrami et Saramati' (2007) 53 Annuaire Français de Droit International 43, 55, K.M. Larsen, 'Attribution of Conduct in Peace Operations: The 'Ultimate Authority and Control' Test', (2008) 19 EJIL 509, 521-522, M. Milanović and T. Papić, 'As Bad as It Gets: The European Court of Human Rights Behrami and Saramati Decision and General International Law', (2009) 58 ICLQ 267, 283-286, A. Sari, 'Jurisdiction and International Responsibility in Peace Support Operations: The Behrami and Saramati Cases’, (2008) 8 HRLR 151, 164. 
Secretary General is also of the view that the question is effective operational control. ${ }^{49}$ In the Srebrenica cases, the Court of Appeal of the Hague also took the approach of effective control.

The distinction in these three cases is that in the Behrami and Saramati cases, ${ }^{50}$ the ECtHR made its deliberations on the issue of its own jurisdiction ratione personae - as the ultimate control, according to the ECtHR was in the hands of the United Nations, there was no jurisdiction. In the cases of the Dutchbat, ${ }^{51}$ the Hague Court of Appeal suggested joint responsibility within the context of civil liability which may be seen as an effort to ensure the effectiveness of legal remedies within domestic law. The ICTY sought to examine whether the question before it had 'an international dimension', whereas the ICJ had to determine to what extent attribution could in fact be established as a pre-requisite of international responsibility. Therefore, it appears that the different judicial organs approached the question of attribution depending on the legal question that appeared before them.

So far, no application has been filed against the EU in the framework of its international responsibility as an international organisation. It remains to be seen how the conduct of CFSP organs will be assessed by the relevant court in relation to the question of attribution. Regardless, however, of the approach to be taken by the potential judicial forum, it is evident that in the specific case of CDSP operations, their direction remains with the Council of the European Union through the Decisions that it adopts.

For example, the decision by the European Council on a European Union Military Mission to contribute to the training of the Malian Armed Forces ${ }^{52}$ provides in Article 5 that the Political and Security Committee shall exercise political and strategic direction of the mission after the authorization of the Council, and shall give regular reports to the Council. Article 6 mentions that the military direction is to be monitored by the EU Military Committee. The latter is the

\footnotetext{
${ }^{49} \mathrm{~S} / 2008 / 354$, para. 16.

50 cf. Behrami and Saramati (n.33).

${ }^{51}$ cf. (n.37).

52 Council Decision 2013/34/CFSP of 17 January 2013 on a European Union Military Mission to Contribute to the Training of the Malian Armed Forces (EUTM Mali) OJ 2013 No. L14/19.
} 
highest military body set up within the Council and it is composed of the Chiefs of Defence of the Member States. ${ }^{53}$

What is evident from the wording is that the Union acts as an independent legal person in this case. Its bodies as well as the forces derived from the Member States may be given delegated powers, such as the Political and Security Committee but the ultimate authorisation derives from the Council. This situation is akin to the one of the different bodies set up in Kosovo on the basis of the Security Council Resolution in the Behrami and Saramati ${ }^{54}$ case.

Therefore, in the EU's case the bodies involved in the operation function under the authorization of each Council Decision. However, as it was stated in the Dutch cases in Bosnia, it is possible for joint attribution to arise: this could mean that the EU may be jointly liable along with its Member States. Another important aspect of that decision is that the Dutch court acted in a way which allowed the Netherlands to be brought as a defendant in a civil liability action, thereby ensuring a judicial remedy in domestic or private law.

Even if the operations do not satisfy the criterion of 'effective control' by the EU supported by the UN's Secretary General and the ICJ, there is a suggestion that they are still to be considered as de facto organs of the Union since the Union exercises a high degree of normative control over them, and therefore the Union should not hide behind the effective control test in Article $7 .^{55}$

The applicable criterion, however, may be deemed to be the one of complete dependency as mentioned by the ICJ in Bosnia v. Serbia, ${ }^{56}$ as these operations do have a position in the organisational structure of the EU.

In the absence of a clear and applicable attribution rule for the EU's international activity, Hoffmeister supports that international and EU rules on attribution overlap and suggests a test by which one may determine whether the action in question is to be attributed to the Union or the Member States. The first question is who is the factual actor of the alleged breach, secondly, who

\footnotetext{
53 cf. van Vooren and Wessel (n.24), 407.

${ }^{54}$ cf. Behrami and Saramati (n.33).

55 cf. van Vooren and Wessel (n.24), 430.

${ }^{56} \mathrm{cf}$ (n.5).
} 
has the legal power to bring an end to the alleged breach and thirdly who bears the international obligation invoked concerning the alleged breach. ${ }^{57}$

Indeed this suggestion is helpful. However, while the first two questions can be answered in the affirmative in situations where the EU is giving directions, the EU's existence of international human rights obligations is still unclear in light of the fact that it has very few signed international commitments to human rights beyond the deliberations it makes in its own treaties. It is also important to remind again the possibility of joint attribution of an act to both the EU and the Member State whose personnel is used, if that doctrine comes to be widely accepted after the decision of The Hague Court of Appeal.

${ }^{57}$ cf. Hoffmeister (n.29) 740. 


\section{Chapter 12}

\section{The EU's Responsibility vis-à-vis Member States Obligations to implement EU Policies}

\section{A. Introduction}

As it is discussed in Chapter 10 above, the EU's human rights obligations deriving from general international law are limited to those that arise out of jus cogens. The violations of these obligations however, could also occur in an indirect way. Beyond the purely external action of the Union it is useful to examine how the Union's policies as they are applied within, and by, its Member States, could possibly lead to engaging the Union's responsibility for human rights violations at an international level.

Section (B) will begin by laying down how the Member States implement EU policies in a way that the legal, judicial and executive systems of the Union and the Member States are in fact acting in a unison akin to federalism, thus having the effect of the EU being a supranational entity whose responsibility may be engaged by the Member States and vice versa. Section (C) will analyse how this responsibility may be triggered in terms of international human rights violations.

\section{B. Member States as Implementing Policies of Executive Federalism}

EU Member States are under many obligations in all areas where the EU has the competence to legislate or make policy. One important question which then arises is whether the EU can possibly be held responsible for breaches of human rights where the Member State is the implementing agent, but the EU has been at the root of the policy. This question is more relevant to situations where the Union is legislating, where all of the Member States are obliged to implement and enforce legal policies that their own legislature has not approved. That is for example Regulations which are directly applicable in domestic law, and also Directives that ought to be transposed and still retain their effect even if not transposed.

Within the framework of the WTO, several deliberations were made regarding whether the Member States are agents of the Union where they implement Union obligations. In the $E C-$ 
Customs Case $^{1}$ the WTO Panel observed that the Union had exclusive competence in the area of customs. The matter raised by the United States was that the European Communities (as they were then) had no uniform administration of laws and regulations with regard to classification and valuation of products for customs purposes and that Communities had no tribunals or procedures for the prompt review and correction of administrative action on customs matters.

According the United States, the non-uniform administration of laws, regulations, judicial decisions and administrative rulings for the classification and valuation of products for customs purposes by the European Communities and the approach to requirements, restrictions or prohibitions on imports resulted in disparate administration among the member States.

The Panel embraced the idea also set forth by Lenaerts and van $\mathrm{Nuffel}^{2}$ that in such cases the Member States implement Union law in a context of executive federalism. The Panel went as far as saying that Member States courts are acting as Union courts where they rule on EU law matters, which is an admission of the principle that national courts ought to implement EU law as part of the domestic legal system. The WTO's Appellate Body quashed the decision but did not contradict the Panel's deliberations on the issue of the EU's responsibility and expressly stated that the Regulations in question were 'administered collectively'. 3

The WTO Panel in EC-Geographic Indications ${ }^{4}$ went even further holding that the Member States act as de facto organs of the Community, for which the Community would be responsible under WTO law and international law in general.

In human rights jurisprudence, the ECtHR, and the now extinct European Commission on Human Rights of the Council of Europe, have mentioned that where a Member State is implementing Union law that is binding in its entirety, it cannot lawfully depart from that law's

\footnotetext{
${ }^{1}$ Panel Report, European Communities - Selected Customs Matters, WT/DS315/R, adopted 11 Dec. 2006.

${ }^{2}$ K. Lenaerts and P. van Nuffel, Constitutional Law of the European Union (Sweet and Maxwell 2nd edn, 2005), $14-47$

${ }^{3}$ Appellate Body Report, European Communities - Selected Customs Matters, WT/DS315//AB/R, adopted 11 Dec. 2006

${ }^{4}$ Panel Report, European Communities - Geographic Indications, WT/DS174/R
} 
provisions, ${ }^{5}$ which then subsequently raises the question of whether the responsibility should lie with the Union rather than with the implementing state.

An initial stance of the ECtHR in Matthews ${ }^{6}$ was that even though the Convention could not prevent the parties from transferring competences to international organisations, they would be responsible if their obligations led to a violation of Convention rights. In this case, the UK denied the right of the applicant to vote in the European Elections in Gibraltar, an action which was based on the Act of Direct Elections of 1976 based on Council Decision 76/787. The reasoning of finding responsibility on behalf of the UK was that the Convention's rights should be enforced practically and should not simply be theoretical.

However, later the ECtHR's analysis shifted towards an approach that favoured the EU being an independent international legal person which ought to take responsibility where a human rights violation is the result of its action. In Bosphorus, ${ }^{7}$ the ECtHR decided that it had no jurisdiction to rule on whether the Union's activities were compatible with Convention rights. The ECtHR, however further underlined that Union law has its own human rights safeguards which are equivalent to the Convention. Where an application is directed against a state which is also a Member State of the Union, regarding its actions while applying Union obligations, the ECtHR shall thus refrain from ruling on the matter.

These cases are perhaps the most illustrious regarding the issue of the Union's international responsibility where a Member State is implementing EU obligations. Within the context of general international law, it would be useful to examine what other sources exist as to the regime of responsibility of international organisations that may arise as a result of an act of one of their state parties.

\section{Member States Implementing EU Obligations and International Human Rights Law}

\footnotetext{
${ }^{5}$ Melchior, (Application No. 13258/87) EComHR, Decision of 9 Feb. 1990, 64 D\&R 138; Bosphoros Hava Yollari Turizm Ve Ticaret Anonim Sirketi v. Ireland (App No.45036/98) ECtHR 30 June 2005 (2006) 42 EHRR 1, at para. 153.

6, Matthews v. United Kingdom (App. No. 24833/94) ECtHR 18 February 1999 (1999) 28 EHRR 361.

7 ; Bosphoros Hava Yollari Turizm Ve Ticaret Anonim Sirketi v. Ireland (App No.45036/98) ECtHR 30 June 2005 (2006) 42 EHRR 1, at para. 153
} 
Articles 15 to $17 \mathrm{ARIO}$ and the Commentary on them also make reference to the issue of international legal obligations of international organisations that may incur through the action of states which are members to them. Article 15 ARIO holds that where an international organisation directs or controls a State or another international organisation to commit an internationally wrongful act then the former international organisation is to be held responsible where it had knowledge of the internationally wrongful act and even where the act was committed directly by it, it would also be responsible.

The meaning of 'direction or control' in the commentary is explained to be similar to the one referred to in Article 17 on the International Responsibility of States - the term 'control' refers to cases of domination over the commission of wrongful conduct and not simply the exercise of oversight and that the word 'directs' does not encompass mere incitement or suggestion but actual direction of an operative kind. ${ }^{8}$ The ARIO Commentary interprets this meaning in the context of an international organisation directing or controlling a state - this would mean that a decision of an international organisation which binds its Member States to act in a specific manner can engage the international organisation's responsibility. ${ }^{9}$

Naturally, this is of importance within the EU's framework. EU legislative and executive acts are binding upon the Member States, which from that point onwards are burdened with the task of implementing the policy. EU measures are characterised by their binding character. Regulations are directly applicable in domestic law, while Directives ought to be transposed by national parliaments into national law. Furthermore, within the context of CSDP operations as mentioned above, it is the European Council which gives directions to the forces made available to it by the Member States. ${ }^{10}$ Therefore, direction or control is something which is often exercised where the EU is taking measures and the Member States (or their subjects) have no discretion in their implementation.

\footnotetext{
${ }^{8}$ Adopted Yearbook of the International Law Commission 2001, vol. II (Part Two), §§6-7 of the commentary on Article 17.

${ }^{9}$ Draft articles on the responsibility of international organizations, with commentaries (2011) Adopted Yearbook of the International Law Commission (2011) vol. II, Part Two, p.38

${ }^{10}$ See for example Council Decision 2013/34/CFSP of 17 January 2013 on a European Union Military Mission to Contribute to the Training of the Malian Armed Forces (EUTM Mali) OJ 2013 No. L14/19.
} 
Article 15 ARIO requires that the international organisation had knowledge of the wrongful act the Commentary adopts the interpretation found in Article 16 of the Articles on State Responsibility, which is also followed in Article 14 ARIO regarding situations where a state or international organisation is aiding or assisting the commitment of a wrongful act - the criterion is whether the international organisation is aware of how its aid or assistance is to be used. Therefore in these circumstances, the criterion is whether the international organisation is aware of the act that is committed due to its direction or control. The requirement in Article 15 ARIO, that the act would also involve the responsibility of the international organisation if it were committed directly by it, according to the Commentary, means simply that the act is contrary to an obligation undertaken by that international organisation. ${ }^{11}$

While Article 15 requires bindingness, Article 16 speaks of 'coercion' whereby the international organisation forces the will of a State to commit the internationally wrongful act. The ARIO Commentary adopts ${ }^{12}$ the interpretation of Article 18 of the ILC articles defining coercion as nothing less than conduct which forces the will of the coerced State will suffice, giving it no effective choice but to comply with the wishes of the coercing state (in this case an international organisation).

This may be perhaps too strong a word to be used for Member States' obligations under EU law, given that these obligations are voluntarily assumed by the Member States when acceding to the Union, and also having in mind that measures passed by the EU usually require the contribution of officials from the Member States. Nevertheless, one could also claim that the existence of the infringement procedure for non-fulfilment of a Member States obligations envisaged by Article 258 of the TFEU is a factor deterrent enough, to coerce a Member State to comply with EU policies.

Another scenario for the engagement of responsibility, provided for in the ARIO, which is highly applicable to the EU, is a situation where an international organisation 'circumvents' its obligations by authorizing or requiring its Member States to commit an internationally wrongful act, as per Article 17. As the Commentary on Article 17 states, where the decision adopted by the

${ }_{12}^{11}$ cf. ARIO Commentary (n.9), p.39.

12 Ibid, 40. 
international organisation is binding, then the breach of the obligation immediately occurs without there needing to be a commitment, ${ }^{13}$ since the binding nature of the decision means that the Member States ought to implement it, unless there is discretion for the Member State, whereby the circumvention must occur. Where the international organisation is authorising an act, as per Article 17(2) and the commentary on it, responsibility occurs only where the State commits the act. ${ }^{14}$

The commentary on the ARIO suggests that even peace-keeping forces can be seen as 'international organisations' and made reference to the KFOR in Kosovo and the French Government's observations in Legality of Use of Force (Yugoslavia v. France), ${ }^{15}$ which took the view that the NATO was responsible for the direction of the actions. This position has also been supported by academic commentary, ${ }^{16}$ which, if accepted, could also mean that forces and missions that are set up under CSDP policies may also be regarded as 'international organisations' (given that more than one state is participating) which are, however, under the command of another international organisation, of which the responsibility may be engaged.

An example which has been given regarding a policy ${ }^{17}$ that is implemented by the Member States is the European Arrest Warrant. While the EAW decision does not in itself infringe any human rights, it allows the authorities of a state to issue a decision to be executed by another Member State for the arrest of a person, in view of prosecution of imposition of a sentence. ${ }^{18}$ It has been noted further that the Framework Decision does not expressly recognise the protection of human rights as a reason for refusal to execute a warrant. ${ }^{19}$ This means that there are circumstances where the Union may not actively infringe human rights itself, but it may instead

\footnotetext{
${ }^{13}$ cf. ARIO Commentary (n.9), p.41

${ }^{14}$ Ibid, p.42

15 Preliminary Objections, p. 33, para. 46.

16 Pellet A., 'L'imputabilité d'éventuels actes illicites. Responsabilité de l'OTAN ou des États membres', in C. Tomuschat, (ed.), Kosovo and the International Community: A Legal Assessment (The Hague: Kluwer Law International, 2002), 193 - 199.

${ }^{17}$ European Regional Office of the United Nations' High Commissioner for Human Rights Report, 'The European Union and International Human Rights Law' <http://www.europe.ohchr.org/Documents/Publications/EU and_International_Law.pdf > p. 15

18 Article 1(1) of Council Framework Decision on the European arrest warrant and the surrender procedures between Member States, 2002/584/JHA, OJ L 190, 18.7.2002, p. 4.

${ }^{19}$ V. Mitsilegas 'The Constitutional Implications of Mutual Recognition in Criminal Matters in the European Union' (2006) 43 CMLRev 1277, 1291-1292.
} 
create situations through its policies which cause the Member States to infringe human rights themselves, while implementing these policies. ${ }^{20}$

The case which has been the source of discussion in this particular field is Melloni. ${ }^{21}$ In this case, Mr. Melloni was convicted in absentia in Italy for eighteen years, a sentence then reduced to ten years. This sentence was upheld upon appeal and cassation. Italy issued a European Arrest Warrant in 2008, requesting his surrender to Italy so that the sentence would be carried out. The matter was referred to the courts of the executing country, Spain. While Spain's Audiencia Nacional granted the surrender, Mr. Melloni referred the case to the Tribunal Constitucional, claiming that his right to fair trial and defence, protected by Article 24(2) of the Spanish Constitution, were under violation. The basis of this argument was that the surrender of a person who has been tried in absentia, should have been made conditional to retrial in the issuing state.

The Tribunal Constitucional then made a reference for a preliminary ruling to the Court of Justice of the European Union on the legal point which was raised by the applicant. The essence of the reference was the following:

"... whether Article 53 of the Charter must be interpreted as allowing the execiting Member State of an EAW to make the surrender of a person convicted in absentia conditional upon the conviction being open to review in the requesting State, thus affording [the right to a fair trial and the rights of defence] a greater level of protection than that deriving from European Union law, in order to avoid an interpretation which restricts or adversely affects a fundamental right recognised by the Constitution of the first-mentioned Member State?"22

Article 53 of the Charter provides that nothing in the Charter shall be interpreted as restricting or adversely affecting human rights as they are recognised in the Member States' constitutions or in international agreements to which the EU and the Member States are parties. The Tribunal had also mentioned that as fundamental rights are part of primary law, secondary law such as the

\footnotetext{
${ }^{20}$ M. Fichera, 'The European Arrest Warrant and the Sovereign State: A Marriage of Convenience?' (2009) 15 ELJ 70, 81-84, L. Komárek, 'European Constitutionalism and the European Arrest Warrant: in Search of the Limits of "Contrapunctual Principles", (2007) 44 CMLRev 16-30.

${ }^{21}$ Case C-399/11 Melloni v. Ministerio Fiscal EU:C:2013:107.

22 Ibid, para 26.
} 
Framework Decision, would have to comply with them. ${ }^{23}$ Such superiority of fundamental rights would therefore shape the interpretation and the implementation of the Member State's obligations to surrender persons against which the EAW has been issued.

Nevertheless, the CJEU took a different approach and stated:

“.... Allowing a Member State to avail itself of Article 53 of the Charter to make the surrender of a person convicted in absentia conditional upon the conviction being open to review in the issuing Member State, a possibility not provided for under Framework Decision 2009/299, in order to avoid an adverse effect on the right to a fait trial and the rights of the defence guaranteed by the constitution of the executing Member State, by casting doubt on the uniformity of the standard of protection of fundamental rights as defined in that framework decision, would undermine the principles of mutual trust and recognition which that decision purports to uphold and would, therefore, compromise the efficacy of that framework decision"24

Therefore the CJEU insisted upon the application of the EU measure even if there were concerns as to its compatibility with human rights. This however creates a dangerous situation, where the Member State is compelled to enforce an EU measure and act in a manner incompatible with the fundamental rights as they are protected in its constitution or even as they are protected in other international instruments to which it is a party. Besselink claims furthermore that attaching this importance to secondary legislation risks erasing the difference between the primary law nature of fundamental rights and secondary law as subject to these rights. ${ }^{25}$

The German Constitutional Court's stance in the Identity Review Order $^{26}$ further demonstrates the reluctance to adopt the approach in Melloni. ${ }^{27}$ In this case the applicant was also issued an EAW by Italy which sought to enforce his sentence and there was doubt as to whether after being issues in Italy he would be permitted a review of the sentence passed in his absence. Remaining faithful to the primacy of the German Basic Law, the Court stated:

${ }^{23}$ Tribunal Constitucional, Orden 6922-2008, June 9, 2011, pp.15-17.

${ }^{24}$ cf. Melloni (n.21) $\$ 63$.

${ }^{25}$ L. Besselink, 'The parameters of constitutional conflict after Melloni' (2014) 39(4) ELR 531-552, 542

${ }^{26}$ 4BVerfG 2 BvR 2735/14 of 15 December 2015

${ }^{27}$ cf. Melloni (n.21). 
"However, the precedence of application of European Union Law is limited by the constitutional principles that are beyond the reach of European integration (integrationsfest) pursuant to Art. 23 sec. 1 sentence 3 in conjunction with Art. 79 sec. 3 GG (2.). This in particular encompasses the principles contained in Art. 1 GG, including the principle of individual guilt in criminal law, which is rooted in the guarantee of human dignity (3.). It has to be ensured that, also in applying the law of the European Union or legal provisions that originate from German public authority but that are determined by Union law, these principles are guaranteed in every individual case (4.)”

The Federal Constitutional Court also made direct reference to Melloni and said of the CJEU's findings:

"These stipulations, however, do not relieve German authorities or courts of their obligation to ensure that the principles of Art. 1 sec. 1 GG are complied with in the context of extraditions executing a European arrest warrant (Art. $23 \mathrm{sec} .1$ sentence 3 in conjunction with Art. 79 sec. 3 GG). Rather, they must ensure that in executing the Framework Decision on the European arrest warrant and the Act on International Cooperation in Criminal Matters, the minimum guarantees of the rights of the accused required by Art. 1 sec. 1 GG will also be observed in the requesting Member State, or where this is impossible - refrain from extraditing the person concerned. To this extent, the principle of mutual trust that governs extraditions within Europe is limited by human dignity guaranteed under Art. 1 sec. 1 GG. It is to this extent, as well, that the court is under a constitutional obligation to conduct the investigations mentioned above."

This may be seen as a rejection of $M e l l o n i^{28}$ and reaffirms the concerns that have been expressed on the compatibility of the EAW with human rights in academic commentary but also in national constitutional courts. ${ }^{29}$

\section{Conclusions}

\footnotetext{
28 G. Anagnostaras 'Solange III? Fundamental rights protection under the national identity review,' ELR 2017, 42(2), 234-253, 253

29 cf. Mitsilegas (n.19) 1294-1299, P. Craig and G. De Búrca EU Texts Cases and Materials (OUP 2015) 992, J Vogel and J Spencer 'Proportionality and the European Arrest Warrant' (2010) Crim LR 474.
} 
The question which therefore arises in terms of the EU's international responsibility in these circumstances is the identity of the respondent, where the Member State violates human rights guaranteed by an international agreement to which it is a party, but that is done on the basis of EU obligations.

Accession of the EU to the ECHR, would be an answer to this challenge, as it would provide for a co-respondent mechanism whereby both the EU and the Member State could be held responsible. This demonstrates the necessity for the existence of a clearer set of human rights obligations for the EU on the international level, through the accession to a multilateral convention for the protection of human rights of a broad range, as well as the need for the ability to hold the EU accountable before its own judicial institutions and potentially domestic courts given the damage that may occur.

Certain alternative routes of holding the EU accountable do exist. The EU's liability for damages in its own legal system can be invoked on the basis of the Article 340 TFEU procedure while the case of Dutchbat in the Court of Appeal of the Hague may also serve as an example by which the court found the conduct attributable to a Member State in order to secure the claimants' interests in light of the lack of jurisdiction over the United Nations. However, it must be borne in mind that international human rights, as well as the rights protected by national constitutional law and national civil and criminal law are all aspects of the same concept of the protection of the individual from behaviour that limits her freedoms, and as such a holistic approach is necessary, without gaps or doubts as to the uniform application of human rights among the supranational, international and national level.

Nevertheless, no such holistic approach appears to exist - there is no clear regime for the EU's human rights responsibility at EU, national or international level while its Member States may be left exposed to human rights related actions, for decisions they take as part of their EU obligations. This reveals the significant gaps which exist.

The essence of this analysis is that theoretically, the Union may be found to violate its international human rights obligations not only where it is acting beyond its own territories or in the context of external action, but also where Member States or agencies under its control are 
implementing its policies. International obligations, as seen in the WTO rulings, permeate issues of implementing policies and thereby rules and conduct of domestic institutions. So while substantive human rights may arise when Member States are implementing EU policies, there is an absence of an international forum where the Union could be held responsible instead of, or along with, the implementing Member State. is an exceedingly theoretical concept, since not only has the EU expressed reluctance for its policies to be reviewed by any external bodies ${ }^{30}$ but also its human rights obligations in international law are not clearly defined.

${ }^{30}$ Opinion 2/13: Opinion of the Court (Full Court) of 18 December $2014 \S 99$. 


\section{Chapter 13}

\section{Remedies potentially available for the breach of international human rights law by the EU}

\section{A. Introduction}

The engagement of the EU's responsibility in international human rights law ought to entail the possibility of obtention of remedies for the victim of the violation. Obtaining a remedy is quintessential for the rectification of the violation, for the substantive delivery of justice and constitutes an integral part of the engagement of legal responsibility in every legal system.

It was discussed in Part I of this thesis that the EU suffers from a remedies deficit. The most significant deficit was identified in the lack of access of potential victims to the remedies offered by the European Convention on Human Rights. The same deficit also persists in the area of international law.

The present Chapter will consequently deal with the notions of victim and damage for within international law. This is followed by an analysis of the potential remedies available for breaches of human rights by the EU within the ambit of public international law. The aim of the present Chapter is to therefore examine the potential applicability of international law remedies to the EU for the violations of international human rights law.

Section B will therefore analyse what are the consequences of a breach of international law by an international organisation. The subject matter of Section $\mathrm{C}$ will be the notions of 'victim' and 'damage' in international law responsibility. Section D will deal with the remedies theoretically available for violations of international human rights law by the EU.

\section{B. The consequences of a breach of international law by an International Organisation}

As it was analysed in Chapters 10 and 11 above, the EU has limited human rights obligations under public international law. In case there is an identifiable breach of a human right, where the EU's conduct is implicated (for example, a person is taken under custody of a CSDP mission and is then inhumanely treated by officials), the next question are the consequences of this violation for the entity that committed it. 
Article 30 ARIO states that where an international organisation is in violation of an international obligation it must cease the act if it is continuing and offer guarantees and assurances that the violation is not going to be repeated. The latter, according to the commentary, ${ }^{1}$ is a new obligation which arises once the violation is found and where there is a risk of repetition.

Remedies can be obtained through individual complaints procedures, where the EU has adhered to a convention and its monitoring system. It has been discussed that within the framework of general public international law the EU could, unless it accedes to a human rights treaty guaranteeing a sufficient range of human rights for all citizens, only violate the rules of customary international law relating to fundamental human rights, those being jus cogens or peremptory norms.

In those situations, the violation will be considered a 'serious breach' of international law, as characterised by Article 41 of the ARIO and Article 40 of the Articles on the Responsibility of States for Internationally Wrongful Acts. Where such a serious violation is to be found there are certain consequences for the international organisation. As per Article 42 ARIO, firstly the international organisation shall cooperate with other international organisations and states to bring an end to the violation found and secondly, no international organisation or state shall recognise as lawful any situation created by the serious breach of international law that has been found.

The Commentary on the ARIO makes reference to an observation of the Organisation for the Prohibition of Chemical Weapons: ${ }^{2}$

"States should definitely be under an obligation to cooperate to bring such a breach to an end because in the case when an international organisation acts in breach of a peremptory norm of general international law, its position is not much different from that of a State."

\footnotetext{
${ }^{1}$ Draft Articles on the Responsibility of States for Internationally Wrongful Acts, with CommentariesYearbook of the International Law Commission, 2001, vol. II, Part Two.

${ }^{2}$ Yearbook of the International Law Commission 2007, vol. II (Part One), document A/CN.4/582, p. 13, para. 56.
} 
The duty of international organisations to take steps to remedy violations of peremptory norms was recognised by the ICJ in Legal Consequences of the Construction of a Wall in the Occupied Palestinian Territory: ${ }^{3}$

"The United Nations, and especially the General Assembly and the Security Council, should consider what further action is required to bring to an end the illegal situation resulting from the construction of the wall and the associated regime, taking due account of the present Advisory Opinion"

It is consequently intrinsic to the role of an international organisation to take steps to bring an end to illegal situations arising out of violations international law and human rights. Therefore, on this yet theoretical level it may be said that on the basis of the ARIO, a finding of a violation of peremptory norms provides an automatic obligation for the international organisation to take measures to bring an end to the violation. Furthermore, it includes the automatic obligation not to recognise as lawful a situation created due to the violation of the peremptory norm - if the ARIO were to apply they would nullify the legal effects of the illegal act, thus giving rise to the right of the victim to be remedied to the fullest possible degree.

\section{The meaning of victim, damage and reparation}

Article 31 ARIO states that where a violation causes material or moral damage then the international organisation must offer reparation for that damage. This is highly relevant to human rights violations as most such cases involve some sort of damage that has been suffered by a natural or legal person. The CJEU in Walz v. Clickair ${ }^{4}$ had made reference to the concept of damage in international law and recognised that in all sub-systems of international law there is a common concept that moral or material damage ought to be compensated.

The ICJ recognised the need for reparation by an international organisation in the specific case of human rights in Difference Relating to Immunity from Legal Process of a Special Rapporteur of the Commission on Human Rights, where it noted that in case of:

\footnotetext{
${ }^{3}$ Legal Consequences of the Construction of a Wall in the Occupied Palestinian Territory, Advisory Opinion, ICJ Reports 2004, p. 136, at p. 200, para. 159

${ }^{4}$ Case C-63/09, Walz v. Clickair SA Judgment of 6 May 2010
} 
“[...] damages incurred as a result of acts performed by the United Nations or by its agents acting in their official capacity ... [t] he United Nations may be required to bear responsibility for the damage arising from such acts. ${ }^{\circ 5}$

The ARIO consider the issues of cessation of the violation and reparation of injury separately. Where injury has been caused the declaratory nature of satisfaction comes as the last resort measure after restitution or compensation. The meaning of 'injury' is very broadly referred to as 'material and moral', thereby allowing a broad range of causes of action while there is no analysis of the doctrine of causation at this international level or the commentary on the ARIO, beyond the question of attribution.

In the framework of state responsibility in international law, the UN's General Assembly has adopted Resolution 60/147, on the Basic Principles and Guidelines on the Right to a Remedy and Reparation for Victims of Gross Violations of International Human Rights Law and Serious Violations of International Humanitarian Law. These are based on the final report of the Special Rapporteur Bassiouni, ${ }^{6}$ which reflected the previous sets of basic principles and guidelines on the rights of reparation for victims of violations of human rights and humanitarian law which had been prepared by the Special Rapporteur Theo van Boven. ${ }^{7}$ The van Boven and Bassiouni draft principles and guidelines defined the approach of international human rights and humanitarian law towards victims. ${ }^{8}$

As per Title IX of the Resolution, there must be adequate, effective and prompt reparation for the victims of gross violations of international human rights and humanitarian law. The Resolution furthermore highlights in Principle 3 that States have the obligation to provide the victims of gross violations of international human rights and humanitarian law, with effective access to a remedy and to justice. While this Resolution was passed prior to the text of the ARIO, it is useful

\footnotetext{
${ }^{5}$ ICJ Reports 1999, pp. 88-89, para. 66.

${ }^{6}$ UN-Doc E/CN 4/2000/62

7 Un-Doc E/CN.4/Sub.2/1993/8 of 2 July 1993, Section IX, E/CN.4/Sub.2/1996/17 of 24 May 1996; E/CN.4/1997/104 of 16 January 1997. See also T. van Boven, 'The right to restitution, compensation and rehabilitation for victims of gross violations of human rights and fundamental freedoms' in G. Alfredsson, The living law of nations (Khel am Rhein, Engel, 1996) 339.

${ }^{8}$ M. Novak, 'The Right to Reparation of Victims of Gross Human Rights Violations' in G. Ulrich, L. Krabbe Boserup (eds) Human Rights in Development Yearbook 2001 - Reparations: Redressing Past Wrongs (Kluwer Law International, Nordic Human Rights Publications 2001) 283.
} 
in having a frame of reference in terms of the remedies theoretically available for violations of human rights by the EU in the sphere of public international law.

According to Principle 8 as included in the Resolution 60/147, a victim is a person who individually or collectively suffered harm, including physical or mental injury, emotional suffering, economic loss or substantial impairment of their fundamental rights, through acts or omissions that constitute gross violations of international human rights law, or serious violations of international humanitarian law. Principle 8 also states that 'where appropriate' in accordance with domestic law, the term 'victim' also includes the immediate family or dependants of the direct victim and persons who have suffered harm in intervening to assist victims in distress or to prevent victimisation.

This is a broad definition of who may be considered a victim as well as of the damage that may be considered reparable under international law. From this viewpoint, damage considered to be reparable is not only a physical or mental injury but also a 'substantial impairment of fundamental rights.' The violation of a fundamental right in this Resolution is actionable per se, given that it is 'substantial', a term which is not explained within the text of the Resolution.

Article 34 ARIO suggests three forms of reparation once the international organisation is found responsible for a violation of international law: restitution, compensation and satisfaction. The Commentary on the ARIO makes a reference to a note of the Director General of the International Atomic Energy Agency, where these three forms of reparation were considered to be applicable to the case of an international organisation, ${ }^{9}$ dated 24 June 1970 where he said that although there may be circumstances when the giving of satisfaction by the Agency may be appropriate, it is appropriate to give consideration to only reparation properly so called which may be either restitution in kind or payment of compensation. In essence, he summarized these three forms of reparation.

It must be noted that within the general public international law academic discourse, the idea of reparation for violations of human rights frequently acquires a different hue compared to the EU or the ECtHR, due to the fact that reparation for violation of rights is intrinsically linked with

\footnotetext{
${ }^{9}$ GOV/COM.22/27, para. 27. See Yearbook 2004, vol. II (Part One), document A/CN.4/545, annex.
} 
issues such as reparation for past wrongs, ${ }^{10}$ by states, governments and entities no longer existent or for the reparation of victims who are no longer alive. Public international law academic discussion on reparation spans over a great range of issues including genocide, claims for colonialism, the Second World War and as such draw much from concepts of law and morality. ${ }^{11}$

Therefore, within this context of international law and particularly having in mind the possible violations of peremptory norms it is only natural that the approach to who may have been a victim of a violation and the reparable damage be more open-ended in comparison to what is the reasoning in the jurisprudence of the CJEU within Article 340(2) or of the ECtHR in relation to restitution or just satisfaction as per Article 41 of the ECHR.

\section{Remedies}

\section{Restitution}

Restitution, as per Article 35 ARIO, is the re-establishment of the situation that existed before the internationally wrongful act, and it is the designated form of reparation where it is materially possible and where it does not impose a disproportionate burden to the defendant. The remedy of restitution has been duly recognised in public international law since the decision of the Permanent Court of International Justice in $1928 .{ }^{12}$ The Permanent Court of International Justice had stated clearly in its judgment:

"The essential principle contained in the actual notion of an illegal act-a principle which seems to be established by international practice and in particular by the decisions of arbitral tribunals-is that reparation must, as far as possible, wipe out all the consequences of the illegal act and reestablish the situation which would, in all probability, have existed if that act had not been committed. Restitution in kind, or, if this is not possible,

\footnotetext{
10 G. Ulrich, 'The Moral Case for Reparations' in G. Ulrich, L. Krabbe, (eds) Human Rights in Development Yearbook 2001 - Reparations: Redressing Past Wrongs (Kluwer Law International, Nordic Human Rights Publications 2001) 369-384, P.B. Hayner, Unspeakable Truths: Confronting State Terror and Atrocity (Routledge, New York and London, 2001), R. Teitel, Transitional Justice (Oxford and New York OUP 2000), R.I. Rotberg and D. Thompson (eds) Truth v. Justice. The morality of Truth Commissions (Princeton and Oxford, Oxford University Press 2000).

11 T. Trhipanyane, 'Current Claims, Regional Experiences, Pressing Problems' in G. Ulrich, L. Krabbe (eds) Human Rights in Development Yearbook 2001 - Reparations: Redressing Past Wrongs (Kluwer Law International, Nordic Human Rights Publications 2001).

12 Factory at Chorzow (Merits) 1928 PCIJ, Series A, No. 17, at 47.
} 
payment of a sum corresponding to the vale which a restitution in kind would bear ; the award, if need be, of damages for loss sustained which would not be covered by restitution in kind or payment in place of it-such are the principles which should serve to determine the amount of compensation due for an act contrary to international law."

In customary international law, restitution is the primary or preferred form of reparation as it closely conforms to the obligation of full reparation set by the PCIJ in Factory at Chorzow because of its 'wiping out' character. ${ }^{13}$ Restitution aims at restoring the situation of the victim to the status quo ante, that means as if the wrongful act had never been committed. ${ }^{14}$

Restitution should, whenever possible, restore the victim to their original situation before the violation occurred. According to paragraph 19 of Resolution 60/147, in relation to the general principles for the reparation of victims of gross human rights and humanitarian law violations, restitution includes, as appropriate restoration of liberty, enjoyment of human rights, identity, family life and citizenship, return to one's place of residence, restoration of employment and return of property. As stated in the ILC's Commentary on the Articles on the Responsibility of States for Internationally Wrongful Acts, ${ }^{15}$ restitution is of particular significance where the violation of the international law norm is continuing and even more so where the violation is against a peremptory norm.

Restitution regarding the restoration of liberty of individuals has been awarded in very early cases relating to international disputes, ${ }^{16}$ as well as property. ${ }^{17}$ In the sphere of international law discourse the term 'juridical restitution' is used where the restitution requires a change in the law or the revocation of a legislative or administrative measure for the purposes of eradicating the

\footnotetext{
13 C. McCarthy, Reparations and Victim Support in the International Criminal Court (Cambridge: Cambridge University Press 2012) 160

${ }^{14}$ ILC's Commentary on the Articles on the Responsibility of States for Internationally Wrongful Acts p. 96.

15 Ibid, 98.

16 Examples of material restitution involving persons include the "Trent" (1861) and "Florida" (1864) incidents, both involving the arrest of individuals on board ships (Moore, Digest, vol. VII, pp. 768 and 1090-1091), and the United States Diplomatic and Consular Staff in Tehran case of the ICJ.

${ }^{17}$ Temple of Preah Vihear, Merits, Judgment, ICJ Reports 1962, p. 6, at pp. 36-37, Hôtel Métropole case, UNRIAA, vol. XIII (Sales No. 64.V.3), p. 219 (1950).
} 
violation, ${ }^{18}$ akin to the individual and general measures recommended by the European Court of Human Rights.

Within general international law, restitution had been used for purposes of reparation following the Second World War. For example, Article 26(1) of the Agreement on the Allied Control in Austria stated that Austria undertook to restore all property that had been confiscated, sequestrated or taken by force on account of the racial origin or religion of the owner and where such restoration was impossible compensation should be granted. This was followed by a series of legislative acts implemented for the purposes of restitution of assets, company shares, reinstatement of company names, rights to patents, trademarks, restitution of employment rights and claims of wages, among other matters. ${ }^{19}$

Another example are the cases of former Yugoslavia and Iraq, where housing restitution was an important legal question. The Agreement on Refugees and Displaced Persons in Annex 7 of the Dayton Agreement provided that all refugees and displaced persons have the right to return to their homes of origin and the right to have restored to them property of which they were deprived in the course of hostilities since 1991.

There are of course cases where restitution is not possible to be achieved in international law, for example in in the case of Forests of Central Rhodope, ${ }^{20}$ the Arbitral Commission could not award restitution of property due to the fact that it had been permanently lost, or destroyed.

Within the framework of damage caused by human rights violations, it is also useful to take into account that where the harm caused is death or permanent injury restitution may not be available. In Aloebeotoe v. Suriname, ${ }^{21}$ where the case involved that nature of harm, the Inter-American Court of Human Rights stated that while restitutio in integrum is one way in which the effect of an internationally wrongful act may be addressed it is not the only way in which it must be

\footnotetext{
${ }^{18}$ Martini case, UNRIAA, vol. II (Sales No. 1949. V.1), p. 975 (1930).

${ }^{19}$ See for a detailed analysis U. Kriebaum, 'Restitution Claims for Massive Violations of Human Rights during the Nazi Regime' in G. Ulrich, L. Krabbe, (eds) Human Rights in Development Yearbook 2001 - Reparations: Redressing Past Wrongs (Kluwer Law International, Nordic Human Rights Publications 2001).

${ }^{20}$ Forests of Central Rhodope (Greece v. Bulgaria) 3 RIAA 1405.

${ }^{21}$ Aloeboetoe et al v. Suriname, Reparations and Costs, 10 September 19993, Interamerican Court of Human Rights, Series C. No. 15, para 49.
} 
addressed. In Pueblo Bello Massacre v. Colombia, ${ }^{22}$ the same Court stated that where restitution is impossible, the international court must determine a series of measures to guarantee the respect of the violated rights.

It is acknowledged that restitution has its limitations within international human rights law. ${ }^{23}$ However, its existence as part of the customary public international law fabric is important to be mentioned. In the event that the EU were to be held responsible in any way on the basis of its customary international law obligations, before an international court or tribunal, this remedy would be available to the potential victim of the violations of the customary international law norms. That is something which is not currently available within the Article 340(2) TFEU procedure but only in a limited way on the basis of Article 263 TFEU which regards the annulment of the contested measure and not the eradication of all the consequences of that measure for the purposes of restoring the status quo ante. This would also clearly make up for the identified gap left by the non-accession to the ECtHR.

\section{Compensation}

Compensation, according to Article 36 ARIO compensates for any financially assessable damage, including loss of profits if this can be established. According to the Commentary to the $\mathrm{ARIO}^{24}$ compensation is the most frequent form of reparation granted by international organisations. ${ }^{25}$

Given the primacy of the remedy of restitution in integrum, compensation comes in as a second option to restitution. McCarthy states that despite the frequency of awards of compensation by international courts, restitution remains the preferred form of remedy and compensation is in reality a substitute where restitution is unavailable. ${ }^{26}$

\footnotetext{
${ }^{22}$ Pueblo Bello Massacre v. Colombia, Merits, Reparations and Costs 31 January 2006, Interamerican Court of Human Rights, Series C., No. 140, para 228.

${ }^{23}$ cf. McCarthy (n.13) 162.

${ }^{24}$ cf. ARIO Commentary (n.1) pp. 56-57.

${ }^{25} \mathrm{cf}$. McCarthy (n.13) 162.

${ }^{26}$ Ibid.
} 
The remedy of compensation has long been recognised within the framework of international law. In the Factory at Chorzow ${ }^{27}$ the PCIJ stated:

"Restitution in kind, or, if this is not possible, payment of a sum corresponding to the value which a restitution in kind would bear; the award, if need be, of damages for loss sustained which would not be covered by restitution in kind or payment in place of itsuch are the principles which should serve to determine the amount of compensation due for an act contrary to international law"

In Gabcikovo - Nagymaros ${ }^{28}$ the ICJ recognised the significance of compensation in the context of interstate claims and stated that it is a well-established rule of international law that an injured State is entitled to obtain compensation from the State which has committed an internationally wrongful act for the damage caused by it. It would be illogical not to expect the application of these rules to the case of international organisations.

Compensation is an established policy of the United Nations for damage caused by it during its operations. In a letter dated 6 August 1965 the Secretary General of the United Nations stated to the Soviet Union: ${ }^{29}$

"It has always been the policy of the United Nations, acting through the Secretary General, to compensate individuals who have suffered damages for which the Organisation was legally liable. This policy is in keeping with generally recognised legal principles and with the Convention on Privileges and Immunities of the United Nations. In addition, in regard to the United Nations activities in the Congo, it is reinforced by the principles set forth in the international conventions concerning the protection of the life and property of the civilian population during hostilities as well as by considerations of equity and humanity which the United Nations cannot ignore."

\footnotetext{
${ }^{27}$ Factory at Chorzow (Merits) 1928 PCIJ, Series A, No. 17, at 47.

${ }^{28}$ Gabčikovo-Nagymaros Project (Hungary/Slovakia) (ICJ Reports 1997).

${ }^{29}$ United Nations, Juridical Yearbook 1965 (Sales No. 67.V.3), p. 41, footnote 26 (document S/6597). The view that the United Nations placed its responsibility at the international level was maintained by J. J. A. Salmon, "Les accords Spaak-U Thant du 20 février 1965", AFDI, vol. 11 (1965), p. 468, at pp. 483 and 487.
} 
The ARIO Commentary also gives the example of the United Nations' reparations that were given regarding the acts of the UN operation in Congo which was established in 1960 in order to restore peace in Congo, as well as the UN Peacekeeping forces in Cyprus, whose task is to ensure the peace along the buffer zone crossing the island. ${ }^{30}$ In fact it mentions that in these occasions the UN has been maintaining the principle of United Nations responsibility vis-à-vis third parties in connection with peacekeeping operations and the obligation of compensation. Compensation has been used also within the framework of the International Criminal Court on the basis of Article 75(1) of the Rome Statute and is also provided for by Article 36 of the Articles on the State Responsibility.

In Difference Relating to Immunity from Legal Process of a Special Rapporteur of the Commission on Human Rights, ${ }^{31}$ the ICJ had declared that the question of immunity of the special rapporteur in relation to legal processes was distinct from the matter of compensation of any damage caused by them during their action, thus distinguishing between these two legal questions and underlining the importance of compensation.

Principle 20 included in Resolution 60/147 relating to the principles for reparation for gross violations of international human rights and humanitarian law, states that compensation should be provided for any economically assessable damage, as appropriate and proportional to the gravity of the violation and the circumstances of each case. The factors taken into account by the relevant court, tribunal or body adjudicating such a case are the physical or mental harm; lost opportunities, including employment, education and social benefits; material damages and loss of earnings, including loss of earning potential; moral damage, and the costs incurred by the victim in seeking legal assistance, medical services, psychological and social services.

The assessment or calculation of the compensation may depend on the circumstances of the victim, as well as by reference to the relevant domestic or regional standards of compensation, although they may not be a decisive consideration in the determination of the compensation. ${ }^{32}$

\footnotetext{
${ }^{30}$ United Nations, Treaty Series, vol. 535, p. 199; vol. 564, p. 193; vol. 565, p. 3; vol. 585, p. 147; and vol. 588, p. 197.

${ }^{31}$ ICJ Reports 1999, pp. 88-89, para. 66.

32 Dispute concerning responsibility for the deaths of Letelier and Moffitt (United States v. Chile) 25 RIAA 3 , PARA 31.
} 
By reference to general international law, an important precedent for the calculation of damages where the subject is the death or serious injury of the victim of a breach of international law, in the Lusitania cases, ${ }^{33}$ where the United States - Germany Claims Commission held the following to be relevant to take into consideration:

"(a) the age, sex, health, condition and station in life, occupation, habits of industry and sobriety, mental and physical capacity, frugality, earning capacity and customary earnings of the deceased and the uses made of such earnings by him; (b) the probate duration of the life of ceased but for the fatal injury, in arriving at which standard lifeexpectancy tables and all other pertinent evidence offered will be considered; (c) the reasonable probability that the earning capacity of the deceased, had he lived, would either have increased or decreased; (d) the age, sex, health, condition and station in life and probable life expectancy of each of the claimants'; $€$ the extent to which the deceased had he lived, would have applied his income from his earnings or otherwise to his personal expenditures from which claimants would have derived no benefits"

Where the subject matter is the loss or damage of property, international law standards take into account the capital value of the property, lost profit, incidental expenses and its 'fair market value'. ${ }^{34}$ For the purposes of non-pecuniary, or moral harm general international law does not deviate from the approach found in the ECtHR which tries to have reference to the "principles of equity' in order to assess and determine non-pecuniary harm..$^{35}$ The specific circumstances of the case, such as the gravity of the violation are also taken into account. ${ }^{36}$

\footnotetext{
${ }^{33}$ Lusitania Cases (United States v. Germany) 7 RIAA 32 p. 35.

${ }^{34}$ American International Group Inc v. Iran 4 Iran-USCTR 96 (1983) p.106, Starrett Housing Corporation v. Iran 16 Iran - USCTR 112 (1987), p. 201.

${ }^{35}$ Velasquez Rodriguez v. Honduras, Reparations and Costs, 21 July 1989, Interamerican Court of Human Rights Series C., No. 7, Isayeva Yusupova and Bazayeva v. Russia (Merits), Judgment of 24 February 2005, 41 EHRR 35, Akdeniz and Others v. Turkey (Merits) judgment of 31 May 2001, 12 Human Rights Case Digest 345.

${ }^{36}$ Wilson v. Philippines, 11 November 2003, HRC Communication No. 868/1999, para 9, see Çakici v. Turkey (App No. 23657/94) ECtHR 8 July 1999 [GC] 31 EHRR 133.
} 
International law jurisprudence, however is not concerned with punitive damages and the concept of awarding damages with the purpose of punishing the respondent State (or in this case the international organisation) does not exist. ${ }^{37}$

\section{Satisfaction}

Where the damage caused cannot be remedied by either restitution or compensation, Article 37 ARIO provides for the remedy of satisfaction, where the relevant international organisation may make an acknowledgement of the breach, an expression of regret, a formal apology or another appropriate modality. The concept of satisfaction in international law was explained by the Arbitral Tribunal in the Rainbow Warrior arbitration, in the framework of state responsibility:

"There is a long established practice of States and international Courts and Tribunals of using satisfaction as a remedy or form of reparation (in the wide sense) for the breach of an international obligation. This practice relates particularly to the case of moral or legal damage done directly to the State, especially as opposed to the case of damage to persons involving international responsibilities." 38

The forms of satisfaction may vary. In paragraph 22 Resolution 60/147 of the UN's General Assembly includes a long list of measures that are regarded as satisfaction. First, there can be effective measures aimed at the cessation of continuing violations; verification of the facts and full and public disclosure of the truth, the search for the whereabouts of the disappeared, for the identities of the children abducted, and for the bodies of those killed, and assistance in the recovery, identification and reburial of the bodies in accordance with the expressed or presumed wish of the victims, or the cultural practices of the families and communities; an official declaration or a judicial decision restoring the dignity, the reputation and the rights of the victim and of persons closely connected with the victim; a public apology, including acknowledgement of the facts and acceptance of responsibility; judicial and administrative sanctions against

\footnotetext{
${ }^{37}$ Velasquez Rodriguez v. Honduras, Reparations and Costs, 21 July 1989, Interamerican Court of Human Rights Series C., No. 7. N. Jørgensen, "A reappraisal of punitive damages in international law", BYBIL, 1997, vol. 68, pp. 247-266; and S. Wittich, "Awe of the gods and fear of the priests: punitive damages in the law of State responsibility", Austrian Review of International and European Law, vol. 3, No. 1 (1998), p. 101.

${ }^{38}$ Case concerning the difference between New Zealand and France concerning the interpretation or application of two agreements concluded on 9 July 1986 between the two States and which related to the problems arising from the Rainbow Warrior affair, UNRIAA, vol. XX (Sales No. E/F.93.V.3), p. 215 (1990).
} 
persons liable for the violations; commemorations and tributes to the victims; inclusion of an accurate account of the violations that occurred in international human rights law and training in international humanitarian law.

One of the earliest cases where the concept of satisfaction was employed is the Corfu Channel ${ }^{39}$ case, where the ICJ declared that a declaration that the act is illegal and contrary to the claimant's rights was deemed to be in itself a form of satisfaction.

"[T] e ensure respect for international law, of which it is the organ, the Court must declare that the action of the British Navy constituted a violation of Albanian sovereignty. This declaration is in accordance with the request made by Albania through her Counsel, and is in itself appropriate satisfaction."

This first form of this particular remedy is therefore a declaration of wrongfulness. This is often accompanied by other forms of reparation. ${ }^{40}$ In the Bosnia Genocide case the ICJ held that declaration of a violation was in itself sufficient because Bosnia had not established a sufficient causal nexus between Serbia's failure to prevent genocide and the harm caused by the genocide in Srebrenica. ${ }^{41}$ Satisfaction consequently has a declaratory value as well.

Another form of satisfaction is rehabilitation, ${ }^{42}$ which may involve taking measures including medical or psychological care for the victim of the human right violation. ${ }^{43}$ The Rome Statute as well as Article 14 of the UN's Convention Against Torture refer to rehabilitation of the victims, with the latter requiring the existence of means within the domestic legal system for 'as full rehabilitation as possible'. In Guridi v. Spain, ${ }^{44}$ the Committee Against Torture held reparation must cover all the damages suffered by the victim, including among other methods, the

\footnotetext{
${ }^{39}$ Corfu Channel (United Kingdom v. Albania) (Merits, ICJ Reports 4 (1949).

${ }^{40}$ Bosnia Genocide (Merits), Rainbow Warrior II (New Zealand v. France) 20 RIAA 217, Bulacio v. Argentina Merits Reparations and Costs 18 September 2003, Interamerican Court of Human Rights, Series C., No 100, Juan Humberto Sanchez v. Honduras Merits, Reparations and Costs, 7 June 2003, Interamerican Court of Human Rights, Series C., No 99.

${ }^{41}$ Ibid, Bosnia Genocide (Merits).

42 The Basic Principles On the Right to Reparation as set in Resolution 60/147 of the UN General Assembly, lists rehabilitation as a free-standing remedy to satisfaction, Principle 21.

43 Ibid.

${ }^{44}$ Guridi v. Spain CAT Communication No. 212/2002, para 6.8.
} 
restitution, indemnisation, rehabilitation of the victim as well as means to guarantee the nonrepetition of the violations having always in mind the circumstances of every case.

The Inter-American Court of Human Rights has ordered payment of medicine for victims, ${ }^{45}$ and even collective rehabilitation. For example in the case of Plan de Sanchez Massacre, which related to the killing of numerous members of an indigenous community in Guatemala, the Court ordered the study and dissemination of the Maya-Achi culture through the Guatemalan Academy of Mayan Languages or a similar organisation, maintenance and improvement of the road system between the communities and the local capital, establishment of a sewage system, supply of teaching personnel and the establishment of a health centre. ${ }^{46}$

In terms of a factual disclosure of the truth in international human rights jurisprudence this may take many forms including information regarding the people who have disappeared such as their time and place of death ${ }^{47}$ or where are the victims remains. ${ }^{48}$ Furthermore, other measures that can be taken is the creation of memorials and conducting commemorations. In General Comment 31, the Human Rights Committee mentions expressly public memorials as a form of satisfaction. ${ }^{49}$

Another possibility is to obtain guarantees of non-repetition of the breach of the international norm. Principle 23 of Resolution 60/147 also suggests a number of measures that can be taken to avoid the repetition of the violation, akin to 'general measures' within the framework of the ECHR and the CRPD those being changes in the law, administration, procedures and institutions to ensure that the violations do not persist. ${ }^{50}$

\footnotetext{
${ }^{45}$ Mapiripan Massacre v. Colombia, Merits, Reparations and Costs, 15 September 2005, Interamerican Court of Human Rights Series C., No 134, para 312, Rochela Massacre v. Colombia, Merits, Reparations and Costs, 11 May 2007, Interamerican Court of Human Rights, Series C No. 163, para 302.

${ }^{46}$ Plan de Sanchez Massacre v. Guatemala, Merits, 29 April 2004, Interamerican Court of Human Rights, Series C., No. 105, paragraph 110.

${ }^{47}$ Quinteros v. Uruguay, 21 July 1983, HRC Communication No. 107/1981, Trujillo- Oroza v. Bolivia, Reparations and Costs, 27 February 2002, Interamerican Court of Human Rights, Series C., no. 92.

${ }^{48}$ Khalilova v. Tajikistan, 30 March 2005, HRC Communication No. 973/2001, Sultanova v. Uzbekistan, 20 March 2006, HRC Communication No. 915/2000.

${ }^{49}$ General Comment No. 31, 26 May 2004, Human Rights Committee, CCPR/C/21/Rev.1/Add13.

${ }^{50}$ As per Principle 23 of Resolution 60/147: Guarantees of non-repetition should include, where applicable, any or all of the following measures, which will also contribute to prevention: (a) Ensuring effective civilian control of military and security forces; (b) Ensuring that all civilian and military proceedings abide by international standards of due process, fairness and impartiality; (c) Strengthening the independence of the judiciary; (d) Protecting persons
} 
The Commentary on the ARIO gives two examples where international organisations have provided an apology as a minimum for the harm they have caused, while not formally admitting to a breach of an international obligation. Firstly, the example of the UN's Secretary - General's statement in relation to the 1994 genocide in Rwanda where it was said by the Secretary General stated:

"All of us must bitterly regret that we did not do more to prevent it. There was a United Nations force in the country at the time, but it was neither mandated nor equipped for the kind of forceful action which would have been needed to prevent or halt the genocide. On behalf of the United Nations, I acknowledge this failure and express my deep remorse." ${ }^{\circ 1}$

The second example given by the ARIO Commentary is the bombing of the Chinese embassy in Belgrade, where a spokesperson of the NATO stated that what 'anybody would do' in this situation is to acknowledge the responsibility early and unambiguously and express regrets. ${ }^{52}$

The EU has the bare minimum of external/international human rights obligations generated by jus cogens norms. Those binding norms may potentially trigger the international responsibility of the Union which in theory would allow the victim to claim this wide range of remedies. The remedies for violations of such norms are not however available for one simple reason to be discussed int the immediately following sector; the EU cannot be brought before an international legal forum where its responsibility would be engaged and the remedies would be offered.

\section{E. Conclusions}

The theoretical engagement of the EU's international responsibility for international human rights law violations could offer improved access to remedies for potential victims. The notion of

in the legal, medical and health-care professions, the media and other related professions, and human rights defenders; (e) Providing, on a priority and continued basis, human rights and international humanitarian law education to all sectors of society and training for law enforcement officials as well as military and security forces; (f) Promoting the observance of codes of conduct and ethical norms, in particular international standards, by public servants, including law enforcement, correctional, media, medical, psychological, social service and military personnel, as well as by economic enterprises; (g) Promoting mechanisms for preventing and monitoring social conflicts and their resolution; A/RES/60/147 9 (h) Reviewing and reforming laws contributing to or allowing gross violations of international human rights law and serious violations of humanitarian law.

${ }^{51}$ www.un.org (Press Release SG/SM/7263). See also the report of the Independent Inquiry into the actions of the United Nations during the 1994 genocide in Rwanda, S/1999/1257, Enclosure.

${ }^{52}$ ure. 266 www.nato.int/kosovo/press/p990509b.htm. 
the victim of a violation of international human rights law is much broader as seen in Resolution 60/147, while the ARIO also refers to 'moral and material' damage as remediable, without specification.

What is perhaps the most important is that the violation of an international human rights norm under these soft-law instruments is 'actionable per se' in the sense that it is in itself considered to be a form of damage, as Resolution 60/147 considers a 'substantial impairment of fundamental rights' to be remediable damage. Having in mind that as it has been analysed above, the EU could only be considered to have jus cogens obligations, their violation would be classified as a substantial impairment of fundamental rights.

Public international law furthermore follows an approach on remedies - restitution, compensation and satisfaction - that are well suited to cases related to human rights violations. This is also evident from the previous discussion on the remedies available within the remit of the ECtHR. This is contrasted to the system of remedies available within the EU's legal order, which have more stringent criteria for the establishment of responsibility or illegality and the obtention of the remedy sought, such as annulment or damages.

Consequently, the establishment of the EU's international responsibility for human rights violations, even through customary international law, would be a very positive step towards victims obtaining the appropriate remedy for the harm they have suffered even if that can only be substantiated as the violation of a right. Naturally this remains on a very theoretical level given that Resolution 60/147, and the ARIO are not binding despite their elaborate development and authoritative character.

Should the responsibility of international organisations be more developed within general public international law, with the establishment of binding rules for responsibility beyond the selfregulation of each organisation, it could be that the existing rules would be further elaborated in either direction. They could possibly become more restrictive to avoid abuse and limitations on the activity of international organisations. They could also be applied in a broad manner to ensure access for remedies and better scrutiny. 
Alas, this possibility stumbles over another enormous obstacle. That is the existence of a legal forum, an institution which would apply the rules on the international legal responsibility of international organisations and by extent the EU. 


\section{Chapter 14}

\section{Procedural obstacles: available legal fora to challenge the EU on the basis of an internationally wrongful act violating human rights}

\section{A. Introduction}

Finally, what is to be examined in the present Chapter, is how the finding of the violation of an international human rights law obligation by the European Union and the claiming of remedies may be made at a legal forum. This is essentially unattainable as the EU cannot be held externally responsible for human rights violations in any other court, tribunal or legal forum outside its own judicial system where it is not bound by a specific international agreement whereby it accepts the jurisdiction of that legal forum.

Section B will therefore explore to what extent the ICJ or the CJEU may be convenient forums for bringing such an application by an applicant. In light of the fact that, as it will be seen, neither of these forms the ideal forum for this nature of applications, it is useful to turn to alternatives and suggestions within international human rights discourse. Section $\mathrm{C}$ will take into account the United Nation's Human Rights Commissioner suggestions on the matter. Section D will take as a 'case study' the example of the EULEX panel, as a model that could be used to ensure international human rights responsibility of the Union. Section E shall therefore explore the more theoretical suggestion of academia; that of the creation of a specialist human rights court on a global level. This analysis will be followed by a conclusionary Section F.

\section{B. The International Court of Justice and the Court of Justice of the European Union}

\section{The International Court of Justice}

The EU is not party to a multilateral human rights convention which covers the basic range of human rights. It is not possible to bring the EU before the European Court of Human Rights or the Human Rights Committee of the International Covenant on Civil and Political Rights, since the EU is not bound by the treaties that these institutions enforce. It is not party to the Optional 
Protocol of the CRPD, and therefore individual complaints cannot be brought against it for violations of that convention.

General international law, such as the rules of jus cogens, is interpreted and enforced by the International Court of Justice, which according to Article 36 of the Statute of the ICJ has jurisdiction over the interpretation of a treaty, any question of international law, the ascertainment of whether a fact is a breach of an international obligation, and the nature or extent of the reparation to be made for the breach of an international obligation.

None of these bodies render decisions which are binding to non-parties to the dispute, such as the EU. The ICJ's statute states specifically that the decisions of the Court have no binding force except for the parties in the particular case. ${ }^{1}$ Article 46 of the ECHR also provides that bindingness applies only to the parties of a dispute. Therefore, a decision by one of these courts which touches upon the matter of violation of a human rights rule by the EU through one of its Member States as a litigant, does not create any direct obligation for the EU.

The jurisdiction of the ICJ is not limited to states that are parties to the Statute or the UN and according to Article 34 it may rule on disputes involving states that are not members of the UN. However, parties in disputes before the ICJ must be states. Therefore, international organisations cannot be parties to a case before the ICJ. Furthermore, human rights claims cannot be brought by individuals or private entities before the ICJ and the only possible scenario is that of an interstate claim - as only States may appear before the ICJ, it only adjudicates cases brought by one state against the other for violations of an agreement that applies to the litigants. ${ }^{2}$ Article 34 of the statute of the ICJ, however provides that when a dispute before the ICJ involves a question of construction of a treaty to which an international organisation is a party then that organisation is notified of the dispute in order to express its stance on the issues arising, but still may not be part of the proceedings.

The question of expanding the jurisdiction of the ICJ on the basis of Article 34 ratione personae arose early on in academic discourse, a few years after the Court's creation. Specifically, in 1954

\footnotetext{
${ }^{1}$ Article 59 of the Statute of the International Court of Justice.

${ }^{2}$ Article 34(1) of the Statute of the ICJ provides that only states may be parties to disputes before it and Article 36 provides that the ICJ hears cases which the parties referred to it therefore allowing only disputes between states.
} 
the Institut de Droit international had adopted a resolution stating that it is a matter of urgency to widen the terms of Article 34 of the Statute to grant access to international organisations of states of which at least a majority are members to the UN or parties to the Statute of the Court. ${ }^{3}$

In 1991, Lauterpacht had argued that Article 34 of the ICJ should be amended so as not to exclude international organisations from being parties to the contentious work of the ICJ $a$ priori, ${ }^{4}$ which could have given rise to access to this forum. The ability of international organisations to become parties to ICJ proceedings is an important subject of discussion but such an expansion of jurisdiction contains uncertainties; for that reason it would be necessary to limit the purposes for which the organisations would be admitted as parties in the proceedings and define carefully the degree of their procedural capacity. ${ }^{5}$

Since the reforms in 2005, Article 43(2) of the Rules of the Court provides that any international organisation being a party to a convention which is invoked in a contentious case between two states may express its views on the matter arising under the convention. According to Hoffmeister, the European Union may act as a sort of amicus curiae to the ICJ on certain interpretative questions. ${ }^{6}$ However, these provisions are again limited to situations where the ICJ is ruling on an international convention to which the organisation is a party and they do not apply to customary law obligations, which are so far the only source of international human rights obligations for the Union.

Nevertheless, it must be stated that despite the recognition that the CJEU has afforded to the jurisprudence of the ICJ, ${ }^{7}$ the Union has declined three times to participate under this label in ICJ procedures, twice regarding issues of maritime delimitation, ${ }^{8}$ and once regarding the UN Narcotics Convention to which the Union has become party only regarding specific aspects. ${ }^{9}$

\footnotetext{
${ }^{3}$ Annuaire de l'Institut de Droit International (1954-II) 45 p. 296.

${ }^{4}$ E. Lauterpacht, Aspects of the Administration of International Justice (Cambridge: Grotius Publications Limited, 1991), 66.

${ }^{5}$ G.I. Hernandez, 'International Court of Justice' in J. d'Aspremont, Participants in the International Legal SystemMultiple Perspectives on non-state actors in international law, (Routledge 2011) 153.

${ }^{6}$ F. Hoffmeister, Litigating against the European Union and its Member States - who responds under the ILC's Draft Articles on international responsibility of international organizations?' (2010) 21(1) EJIL 723-747, 725.

${ }^{7}$ See for example Case T-115/94 Opel Austria v. Council [1997] ECR II-39 \$90.

8 ICJ, Case concerning territorial and maritime dispute between Nicaragua and Honduras (Nicaragua $v$. Honduras), Judgment of 8 Oct. 2007, at para. 4; Pursuant to the instructions of the Court under Article 43 of the
} 
Van Vooren and Wessel's position is that the ARIO's role in establishing an international responsibility regime for the case of the EU can be limited to an argumentative fashion. This is because the ICJ only rules in disputes between states, while international organisations also enjoy general immunity. ${ }^{10}$ Therefore the potential applicability of the ARIO, should they ever become a binding piece of law, seems rather onerous - this may be contrasted to the fact that the judgments of the ICJ are binding at least, inter partes and form by virtue of Article 38(d) of the Statute of the ICJ, part of the fabric of international law.

Furthermore, another important point to be made in this context is that the ICJ cannot accommodate claims by individuals so it would be important to consider who would be the claimant against the EU, if it were to be brought before the ICJ. Naturally, a state could initiate the potential proceedings. The ideal situation would be if there was an extension of the jurisdiction of the ICJ to include private persons in its proceedings, which is a controversial matter. This would require a radical alteration of the ICJ's Statute and its judicial structure. ${ }^{11}$ This could possibly be contrary to the basic principles of international law and international judicial organisation. ${ }^{12}$

This lack of external forum where the Union may be held responsible for possible human rights violations accentuates two already existing issues. The first issue is the need for the Union to accede to international human rights instruments, such as the European Convention on Human

Rules of Court, the Registrar addressed to States parties to the United Nations Convention on the Law of the Sea of 10 December 1982 (hereinafter "UNCLOS") the notifications provided for in Article 63, paragraph 1, of the Statute. In addition, the Registrar addressed to the European Union, which is also party to that Convention, the notification provided for in Article 43, paragraph 2, of the Rules of Court, as adopted on 29 September 2005, and asked that organization whether or not it intended to furnish observations under that provision. In response, the Registrar was informed that the European Union did not intend to submit observations in the case Case concerning delimitation in the Black Sea (Romania v. Ukraine), Judgment of 3 Feb. 2009, at para. 3 Pursuant to the instructions of the Court under Article 43 of the Rules of Court, the Registrar addressed to States parties to the United Nations Convention on the Law of the Sea of 10 December 1982 the notifications provided for in Article 63, paragraph 1, of the Statute of the Court. In addition, the Registrar addressed to the European Community, which is also party to that Convention, the notification provided for in Article 43, paragraph 2, of the Rules of Court, as adopted on 29 September 2005, and asked that organization whether or not it intended to furnish observations under that provision. In response, the Registrar was informed that the European Community did not intend to submit observations in the case.

${ }^{9}$ F. Hoffmeister and Ondrusek, 'The European Community in International Litigation', (2008) 61 Revue Hellénique de Droit International 205, 213.

${ }^{10}$ B. van Vooren and R. Wessel, EU External Relations Law, Text, Cases and Materials (CUP 2014) 242

${ }^{11}$ cf. Hernandez (n.5) 154.

${ }^{12}$ H. Lauterpacht, 'The Revision of the Statute of the International Court of Justice' (2002) 1 Law and Practice of International Courts and Tribunals, 109. 
Rights which would mean that the Union would undertake full international human rights obligations, beyond the minimum of jus cogens.

2. The Court of Justice of the EU applying international law vis-à-vis human rights violations by the EU

The second issue under discussion is the jurisdiction of the Union's own judicature over human rights issues, particularly when such considerations arise while the Union is acting as an international legal person. While the CJEU according to Article 263(2) TFEU has the ability to annul a legislative or administrative act of the Union if the Union does not respect a fundamental right of the Charter, the CJEU lacks a general jurisdiction over human rights questions regarding the CFSP/CSDP. ${ }^{13}$ Under the three pillar structure, the CJEU had no competence on either the external policy of the EU or the internal security policy (justice, police cooperation and home affairs). Following the passage of the reforms in 2009, the justice and home affairs were brought under the jurisdiction of the Court. Today Article 24(1) TEU expressly excludes the CFSP from the jurisdiction of the CJEU except for two cases: firstly, the jurisdiction granted to the CJEU by virtue of Article 40 TEU regarding competences and secondly the jurisdiction granted by the second paragraph of Article 275 TFEU.

Following the Kadi litigation, where it was evident that measures which may have an adverse effect on the lives of individuals, arose the need for a certain safeguard and the lack of the jurisdiction was sharply criticised. ${ }^{14}$ According to Article 275 TFEU it is now possible for the CJEU to examine the legality of a CFSP act which imposes restrictive measures on individuals. Nevertheless, the Union's judiciary lacks jurisdiction when competences and decision-making procedures within the CFSP legal order are at stake because the Court does not scrutinise either the decision-making procedure or the legal basis of the CFSP measure. ${ }^{15}$

\footnotetext{
${ }^{13}$ M. Brkan, 'The Role of the European Court of Justice in the Field of Foreign and Security Policy after the Treaty of Lisbon: New Challenges for the Future', in P.J. Cardwell (ed), EU External Relations Law and Policy in the PostLisbon Era (The Hague: T.M.C. Asser Press, 2012) 100.

${ }^{14}$ P. Eeckhout, 'Does Europe's Constitution Stop at the Water's Edge? Law and Policy in the EU's External Relations', (2005) Walter van Gerven Lectures, Leuven.

${ }^{15} \mathrm{cf}$. van Vooren and Wessel (n.10), 379.
} 
In the context of the EU's proposed accession to the European Convention on Human Rights the Commission had made submissions to the CJEU that an action for non-contractual liability and damages is not excluded by Article 275 and that all measures of EU law are subject to the CJEU's jurisdiction if Articles 19(1) TEU Articles 275 and 340 TFEU and Article 1(4) of the Draft Accession Agreement were combined. ${ }^{16}$ This submission, which was made in order to support the compatibility of the Accession with EU law, the CJEU did not expressly accept this as a valid point. In its Opinion, the CJEU was careful in its wording. It pointed out that the matter of jurisdiction under Article 275 has not yet been subject to the CJEU's interpretation and it did not attempt to interpret it in its Opinion, either. It instead held that

"as EU law now stands, certain acts adopted in the context of the CFSP fall outside the ambit of judicial review by the Court of Justice... That situation is inherent to the way in which the Court's powers are structured by the Treaties, and, as such, can only be explained by reference to EU law alone". ${ }^{17}$

Therefore, the CJEU decided to stay within the restrictive wording of the Treaty and did not attempt in any way to adopt an interpretation which would essentially extend its own competences. In the same context, an Advisory Opinion was delivered by Advocate General Kokott, whose view on the Commission's arguments was more direct. The Advisory Opinion of the Advocate General, as per the EU's judicial system is not binding upon the Court but rather offers an interpretation and analysis which may be taken into account by the Court during its decision. Being of the opinion that the Accession was compatible with EU law and that the review of CFSP acts was something possible in national courts, she stated the following:

“89. First, the Commission's interpretation disregards the relationship between rule and exception that underpins Article 275 TFEU; the Commission turns the principle that the Courts of the EU have no jurisdiction in relation to the CFSP, as laid down in the sixth sentence of the second subparagraph of Article 24(1)TEU and the first paragraph of Article 275 TFEU, on its head. Secondly, in assuming that the Court of Justice has jurisdiction in preliminary ruling proceedings and actions for damages in the context of

\footnotetext{
${ }^{16}$ Opinion 2/13: Opinion of the Court (Full Court) of 18 December $2014 \S 99$.

17 Ibid, paragraphs 249-253.
} 
the CFSP, the Commission contravenes the clear wording of the second alternative in the second paragraph of Article 275 TFEU, which refers only to jurisdiction for actions for annulment brought by individuals in accordance with the fourth paragraph of Article 263 TFEU against restrictive measures, but not to any other subject-matter of an action or type of action, and certainly not to references from national courts or tribunals as provided for in Article 267 TFEU."

The CFSP remains largely outside the CJEU's jurisdiction in relation to any other action apart from the review of legality of restrictive measures. Therefore - this seems to exclude CFSP acts to be the basis of a damages' action under Article 340 TFEU. It has been claimed that this is made up by the fact that Article 19 TEU provides that the Member States also have the duty to provide remedies for fields covered by EU action. ${ }^{18}$ There remains an important gap both in the possibility of establishing the responsibility of the EU for breaches of international human rights law as well as obtaining actual remedies for such breaches.

Indeed academic commentators suggest that the CJEU ought to become another human rights court where constitutional human rights discourses may take place. ${ }^{19}$ The problem, however, apart from the fact that the CJEU has no jurisdiction in CFSP areas, is that the CJEU is not a human rights court, since its approach to human rights is that the protection of human rights must accord the purposes of EU law. ${ }^{20}$ If the responsibility of the EU regarding human rights remains only with the CJEU, the court risks becoming more and more self-referential which would result in marginalisation of other human rights instruments outside its own legal order, ${ }^{21}$ which would mean that the EU would develop its own free-standing level of protection of human rights.

\section{Suggestions of the UNHCHR Regarding Potential Scrutiny of EU Action}

The European Office of the UN's High Commissioner for Human Rights has suggested that the EU could create informal arrangements with international human rights treaties monitoring

\footnotetext{
${ }^{18}$ F. Naert, 'The International Responsibility of the Union in the context of its CSDP Operations' in M. Evans and P. Koutrakos, (eds), The International Responsibility of the European Union (Hart Publishing 2013) $313,318$.

${ }^{19}$ S. Iglesias Sanchez, 'The Court and the Charter: The Impact of the Entry into Force of the Lisbon Treaty on the ECJ's Approach to Fundamental Rights' (2012) 49 CMLRev 1578.

${ }^{20}$ Opinion of AG Bot, Case C-399/11 Melloni, EU:C:2013:107§106.

${ }^{21}$ R. Burchill, 'Assessing the European Union's Position on Human Rights: Is it a Desirable One?' in J. Wetzel, (ed) The EU as a 'Global Player' in Human Rights? (New York, Routledge, 2011) 20.
} 
bodies. $^{22}$ In its Report, the Office gives the examples of the Cotonou Agreement, for which the Union has struck up an agreement with the Human Right's Council High-Level Task force, to evaluate the Cotonou Agreement regarding the implementation of the right to development, ${ }^{23}$ or the arrangement that has been set up regarding the EU's compliance with the Geneva Convention on Refugees through which the Union will exchange information regarding asylum matters with the UN's High Commissioner for Refugees. ${ }^{24}$ The European Office of the UNHCHR suggests that in all situations where the EU would be subject to the monitoring of these international bodies, it should delineate clearly the limits and scope of its competences, and also establish internal mechanisms, particularly within the Commission to ensure that the monitoring which takes place by these bodies has an effect on legislating and policy-making. ${ }^{25}$

Nevertheless, this cannot substitute any type of judicial scrutiny whereby the EU's responsibility would be at stake. Rather, this is an alternative form of scrutiny and not a means of establishing responsibility through a direct action brought by a claimant or a victim of a human rights violation.

If and where the EU decided to in fact accede to an international human rights instrument, engaging with these international monitoring bodies would mean that the Union would also engage in periodic reporting, ${ }^{26}$ something which has begun regarding the Union's obligations under the CRPD. ${ }^{27}$ This would also mean issuing general comments, which according to the

\footnotetext{
${ }^{22}$ European Regional Office of the United Nations' High Commissioner for Human Rights Report, 'The European Union and International Human Rights Law', <http://www.europe.ohchr.org/Documents/Publications/EU_and_International_Law.pdf $>2$.

${ }^{23}$ High-Level Task Force on the Implementation of the Right to Development, 'Technical Mission Report: Cotonou Partnership Agreement between the European Union (EU) and African, Caribbean and Pacific (ACP) countries', UN Doc. A/HRC/8/ WG.2/TF/CRP.4, 28 December 2004.

${ }^{24}$ Exchange of letters between the United Nations High Commissioner for Refugees and the European Commission, of 15 February 2005, available at: <http://www.unhcr.org/refworld/docid/42135cba4.html.> Accessed 25 February 2016.

${ }^{25}$ cf. The European Union and International Human Rights Law (n.22), p. 34.

${ }^{26}$ Ibid, p.38.

${ }^{27}$ Provisional Draft, Information Note from the Commission on progress in implementing the UN Convention on the Rights of Persons with Disabilities. Available at http://ec.europa.eu/social/main.jsp?catId=431\&langId=en. Report on the implementation of the UN Convention on the Rights of Persons with Disabilities, with special regard to the Concluding Observations of the UN CRPD Committee (2015/2258(INI)).
} 
UNHCHR's Office could begin by adapting previous deliberations to the EU's particular case, ${ }^{28}$ and also individual petitions. ${ }^{29}$

\section{Case study: the EULEX Panel}

An innovation in the field of investigating the EU's responsibility for human rights violations is the establishment of the Human Rights Review Panel of EULEX, the EU's mission in Kosovo, which examines complaints regarding human rights against the mission. ${ }^{30}$

The role of EULEX in Kosovo is to assist Kosovo's judicial authorities and law enforcement agencies $^{31}$ in light of the fact that Kosovo is still a newly established state in an area of Europe that has been reforming. The objective is to ensure that Kosovo's institutions are impartial and free from political interference.

EULEX forms part of Kosovo's judicial and prosecutorial system. According to Article 3(d) of the Council Joint Action establishing it, it has competences in the areas of forensic medicine and police, including security operations, a residual witness protection programme and the responsibility to ensure the maintenance and promotion of public order and security including through reversing or annulling operational decisions taken by the competent Kosovo authorities. ${ }^{32}$ In judicial cases, it is even possible to have a EULEX judge, while there is also the possibility of a EULEX Prosecutor. ${ }^{33}$ The mission has a mandate until June 2020 under the possibility of renewal ${ }^{34}$ while most of its competences have been passed onto Kosovo's national authorities. ${ }^{35}$

\footnotetext{
${ }^{28}$ cf. The European Union and International Human Rights Law (n.22), p.39.

${ }^{29}$ Ibid, p.41.

${ }^{30}$ Human Rights Review Panel <http://www.hrrp.eu/relevant-rights.php $>$

${ }^{31}$ Article 2, Council Joint Action 2008/124/CFSP of 4 February 2008, on the European Union Rule of Law Mission in Kosovo, EULEX Kosovo, Amended by Council Decision (CFSP) 2018/856 of 8 June 2018 amending Joint Action 2008/124/CFSP on the European Union Rule of Law Mission in Kosovo.

32 Article 3(d) Council Decision (CFSP) 2018/856 of 8 June 2018 amending Joint Action 2008/124/CFSP on the European Union Rule of Law Mission in Kosovo, see also D. Doli and F. Korenica 'The EU-engineered hybrid and international specialist court in Kosovo: how "special" is it?' (2016) 12(3) ECLR 474-498, 476.

${ }_{33}$ D. Doli and F. Korenica "How powerful are Eulex judges and prosecutors in Kosovo', (2010) Revista General de Derecho Penal 14.

${ }^{34}$ EULEX Kosovo <http://www.eulex-kosovo.eu/?page=2,16>

35 'EULEX - Towards an integrated exit strategy - Strengthening the rule of law through EU integration', A Policy Report by GLPS and DPC No. 05 (April 2014).
} 
In light of the fact that EULEX is encumbered with tasks related to the administration of justice, its tasks must be done in respect of the right to a fair trial ${ }^{36}$ and the right to liberty and security 37 and the prohibition of punishment without law. ${ }^{38}$ Where EULEX reviews decisions of Kosovo's judicial authorities to ensure the rule of law, it is also exercising judicial functions therefore respect for these rights is necessary as violations may occur. ${ }^{39}$ Similarly the existence of a police component in this particular mission ${ }^{40}$ also has an interaction with human rights related to detention and the use of force by police authorities. In fact the police component of EULEX operates completely independently of Kosovo authorities and with a chain of control related only to EULEX from the head of the mission to the individual officer, revealing a thread of attribution leading to the EU, rather than Kosovo or the contributing member state. ${ }^{41}$

The EULEX Human Rights Review Panel applies the most important human rights instruments the ECHR, the UNDHR, the ICCPR, ICESCR, the CERD, the CEDAW among others and heavily relies on the jurisprudence of the ECtHR. The Panel is composed of four experts in human rights law - two external members and two EULEX members, of which one is a substitute for the other. ${ }^{42}$ Each year it issues an Annual Report. Until 2015, the Panel made a finding of a violation in fifteen out of the 152 cases brought before it, ${ }^{43}$ and by 2019 its caseload has increased considerably.

The range of human rights invoked before the Panel is also an important evidence of issues that may arise within the framework of CFSP/CSDP action. Even though no violation was found, the case of $K, L, M, N, O, P, Q, R, S \& T$ ( $K$ to $T$ ) against EULEX, ${ }^{44}$ is important. In this case the complainants were Serbs attending Christmas celebrations in a monastery and were arrested and assaulted by Kosovan police forces. The claim was that EULEX did not protect the applicants'

\footnotetext{
${ }^{36}$ Article 6 of the ECHR and Articles 47 to 50 of the EU Charter of Fundamental Rights.

${ }^{37}$ Article 5 of the ECHR, Article 6 of the EU Charter of Fundamental Rights.

${ }^{38}$ Article 7 of the ECHR, Article 50 of the EU Charter of Fundamental Rights.

39 S.O. Johansen 'Accountability mechanisms for human rights violations by CSDP missions: available and sufficient?’ (2017) 66(1) ICLQ 181-207, 188.

${ }^{40}$ Article 6(3)(b).

${ }^{41}$ M. Spernbauer, EU Peacebuilding in Kosovo and Afghanistan: Legality and Accountability (Brill 2014$), 328$.

42 Human Rights Review Panel for EULEX, Annual Report for 2019 https://hrrp.eu/docs/HRRP\%20Annual\%20Report\%202019.pdf.

43 Human Rights Review Panel for EULEX, Annual Report for 2015 <http://hrrp.eu/docs/HRRP\%20Annual\%20Report\%202015.pdf >

44 nos. 2013-05 to 2013-14
} 
rights not to be unlawfully arrested and their right to manifest their religion (Article 9 ECHR). This comes to demonstrate that since the EU had become actively involved in an area with the objective of promoting the rule of law, its mission there willingly takes the obligations not only to refrain from violations of human rights but also a positive obligation to promote them.

For example, in the case of L.O. v. EULEX, ${ }^{45}$ the Panel examined the issue of the possible violation of Articles 2 and 3 of the ECHR due to the fact that the claimant appealed to EULEX for the investigation of the disappearance of her husband. EULEX never disclosed to her information about the investigation, prompting her to file a complaint. The Panel indeed found a violation of the said Articles.

Another case where a violation was found was, $X$ and 115 other complainants against EULEX, ${ }^{46}$ where the complainants had turned to EULEX for the investigation of the living conditions in the camps of internally displaced persons - the Panel found that the reluctance on the part of the EULEX Prosecutors to proceed to an investigation was in violation of Article 13 ECHR - the right to an effective legal remedy. Another important aspect that is revealed by this case was that there was a follow-up decision whereby the Panel also examines to what extent measures are taken to remedy a violation.

Indeed the Panel can make, under Rule 45bis of its Rules of Procedure, recommendations for remedial action by the Head of Mission and then follow up its decision. In the first follow-up decision of $X$ and 115 other complainants against EULEX, ${ }^{47}$ the Panel found that there was only partial compliance by the Head of the Mission who did not provide evidence that the investigation was sufficiently in progress. By 2019 the Panel noted that the applicants had yet to be provided with an effective remedy. ${ }^{48}$

In $F$. and Others against EULEX, ${ }^{49}$ there was a finding of a violation of the procedural limb of the right to life as well as a violation of the freedom from torture, inhuman and degrading treatment. The recommendations were followed and the Head of Mission had proceeded to

\footnotetext{
${ }^{45}$ L.O. against EULEX, 2014-32, 11 November 2015

46 case no. 2011-20, X and 115 other complainants against EULEX

47 case no. 2011-20, X and 115 other complainants against EULEX, Follow-up decision, 11 November 2011.

48 case no. 2011-20, X and 115 other complainants against EULEX, Follow - up decision, 27 March 2019.

${ }^{49}$ Case 2011-27 F. and Others against EULEX, follow up decision 11 June 2019.
} 
making steps declaring his apologies and sympathy. From that viewpoint, the Panel may play an instrumental role in the provision of remedies for human rights violations, through the recommendations.

What is more is that under Rule 43 of the new Rules of Procedure that have been enacted in 2019, it is possible for both the complainant and the respondent to request a review of the decision in light of new factual evidence that was not known at the time of the first adjudication. Rule 22 also provides for interim measures to be taken in order to protect further violations of human rights.

Therefore, the EULEX Panel should set an example, as it is an accessible legal forum for human rights cases related CSDP operations and functions as an alternative to the lack of the CJEU to adjudicate on human rights issues and the CSDP and compensates to a degree, for the lack of international responsibility of the EU as an international organisation. The fact that it does not directly provide for remedies but rather recommendations, however demonstrates that there is still a remedies deficit even at this specialized level. Nevertheless, the cases it deals with form important examples of the human rights problems which may arise in such operations. Such panels or institutions ought to be established in other CDSP missions in order to fill in a gap left in the jurisdiction of the CJEU.

\section{E. Proposals for a World Human Rights Court}

The matter of lack of general jurisdiction of international courts vis-à-vis international organisations, and in particular on the matter of human rights has been noted at the academic and theoretical level.

A far reaching and certainly theoretical option or proposal is the creation of a World Human Rights Court which would have a universal jurisdiction on human rights matters, over states, as well as 'other entities'. This was developed within the framework of the Swiss Agenda for 
Human Rights. ${ }^{50}$ Also in the COST action on the role of the EU in UN Human Rights reform, ${ }^{51}$ a consolidated Statute and Commentary for a World Court of Human Rights was drafted. ${ }^{52}$

In this proposal Article 4 of the proposed Statute uses the term entity as any intergovernmental organisation, including business corporations, that has recognised the jurisdiction of the proposed courts. The judgments of the future World Court shall be final and binding under international law and the implementation of the judgments would be supervised by the UN High Commissioner for Human Rights and enforced by the Human Rights Council or the Security Council.

According to the proposed statute, ${ }^{53}$ if the Court finds a violation by any state, or party or entity it may afford the victim adequate reparation for the harm suffered, such as restitution, rehabilitation, compensation, guarantees or any other type of satisfaction.

This proposal which definitely agrees with the aspirations of human rights proponents may not, however, have such a success with the EU. In light of the EU's skepticism to proceed to the accession to the ECtHR, although already envisaged by its internal law, it would be difficult to imagine that the EU would come to accept the jurisdiction of a World Court of Human Rights on the basis of Article 4 of the proposed statute.

\section{F. Conclusions}

As there is no coherent or universally accepted regime for the rules applicable to the responsibility of international organisations, the EU's external accountability is further undermined. Even the enforcement of peremptory norms in the case of the Union is again a very

\footnotetext{
50 Swiss Confederation, Federal Department of Foreign Affairs DFA/ Geneva Academy of International Humanitarian Law and Human Rights, Protecting Dignity: An Agenda for Human Rights.

${ }^{51}$ M. Nowak et al (eds) The Role of the EU in UN Human Rights Reform (Wien/Graz, Neuer Wissenschaftlicher Verlag, 2013).

52 J. Kozma et al A World Court of Human Rights - Consolidated Statue and Commentary (Wien/Graz, Neuer Wissenschaftlicher Verlag, 2010), M. Nowak, 'Eight Reasons why we need a World Court of Human Rights' in J. Grimheden et al, (eds) International Human Rights Monitoring Mechanisms: Essays in Honour of Jacob Th Moller, $2^{\text {nd }}$ edn (Leiden/Boston, Martinus Nijhoff Publishers 2009) 697, M. Nowak, 'It's Time for a World Court of Human Rights' in M.C. Bassiouni and W.A. Schabas (eds), New Challenges to the UN Human Rights Machinery - What future for the UN Treaty Body System and the Human Rights Council Procedures? (Cambridge/Antwerp/Portland, Intersentia 2011).

${ }^{53}$ Article 17.
} 
hypothetical scenario, since the Union cannot be brought before any international legal forum for the violation of peremptory norms.

This enforcement of human rights obligations could be supported where the Union makes arrangements for informal cooperation with human rights monitoring bodies, as it has been in the case of the Geneva Convention on Refugees, ${ }^{54}$ yet such arrangements do not substitute judicial control. This additionally underlines the need for the EU to accede to an international human rights instrument. The creation of alternatives to external review by specialised bodies, such as the Human Rights Review Panel in EULEX would be a way to ensure, at least fragmentally, the Union's responsibility for the violation of international human rights norms and to put pressure for substantially remedying the violation.

The lack of external responsibility and obligations accentuates the 'parallel' way in which EU human rights law develops through the Charter and the CJEU's jurisprudence, as compared to international human rights law. The risk is establishing a two-tier system, which could strike at the heart of the universality that ought to characterise human rights, and that any disparity in the protection offered by the two regimes will in effect undermine the EU's credibility towards third states and other international organisations. ${ }^{55}$

\footnotetext{
54 cf. (n.24).

55 European Regional Office of the United Nations' High Commissioner for Human Rights Report, 'The European Union and International Human Law',

<http://www.europe.ohchr.org/Documents/Publications/EU_and_International_Law.pdf> p.7.
} 



\section{CONCLUSION}

\section{Revisiting the research question}

The subject matter of this thesis is the existence and effectiveness of remedies available to the individual in relation to human rights violations committed by the EU and its institutions. The fundamental hypothesis set out at the beginning of the Thesis is that the current legal regime regulating EU action and the EU's institutional obligations, does not effectively provide for substantive remedies where human rights have been violated by EU institutions.

The research conducted affirms the above hypothesis. The essence of the legal analysis leads to the conclusion that despite the European Union's considerable efforts to promote human rights, there is no coherent or uniform legal framework envisaging a holistic and effective protection of human rights vis-à-vis Union action. The current legal framework for human rights-based claims against the European Union is insufficient, with considerable drawbacks for the engagement of the EU's accountability, leading to severe deficiencies where an individual seeks any form of legal or substantive remedy for alleged violations of human rights by the EU. This conclusion is reached by combining the findings made in each Chapter of the thesis.

The thesis posed certain overarching questions which were answered through the analysis, and this will be answered in a summarised, cohesive and substantive manner in this Chapter. Following that, this Chapter will proceed to making some suggestions and proposals for the improvement of the accessibility of applicants to remedies.

\section{Summary of Findings}

Question 1: Does the current legal framework applicable for the scrutiny of legality of EU action allow individual applicants to contest EU measures effectively, on the basis of their incompatibility with human rights and obtain a remedy?

Answer: Individual applicants face significant hurdles where they directly contest EU measures as to their compatibility with human rights, thus having significant problems in obtaining a remedy. A remedies 'deficit' is consequently observed. 


\section{Reasoning:}

The absence of accession of the European Union to the European Convention on Human Rights is a goal that has remained unattained. Accession to the ECHR would be the clearest solution for the accountability of the EU for human rights violations and obtaining the relevant remedies.

The obligation contained in Article 6(2) for accession of the EU to the European Convention on Human Rights remains unfulfilled. It has left the significant problem of lack of accountability and accessibility to remedies in relation to human rights violations by the EU unresolved. By consequence, individual applicants claiming that their rights have been infringed cannot have access to the remedies provided by the European Court of Human Rights. Those include the recognition of a human right violation and the access to substantive remedies such as just satisfaction, restitution and general measures, leading to the reform of the legal regime that has allowed the violation. This lack of accession is significantly problematic, given that while the EU pledges to respect the ECHR there is no formal way to hold the EU accountable for its violations given that it is not formally part of EU law. Consequently, persons whose rights may be violated by the EU are deprived of the possibility of accessing the remedies of the most rigorous system of human rights protection worldwide.

To obtain substantive redress against violations of her rights by the EU, the individual ought to find the solution within the provisions of EU law, before the EU judicature. The action of annulment provided by Article 263 TFEU, is the action which is expressly and directly related to fundamental rights. A violation of a fundamental right protected by EU law constitutes an EU act illegal and subject to annulment. Annulment is the direct method of eradicating the violating act with the purpose of rendering it annulled and ineffective, ab initio.

The standing requirements for the action of annulment (as they have been discussed in Chapter 2) have been interpreted so very strictly by the CJEU to the point that individual applicants can rarely fulfil them where the measure in question is not directly addressed to them. The test of 'direct and individual concern' is an insurmountable obstacle. This is against the principle of effective judicial protection; the strict interpretation renders the remedy inaccessible thus making 
the protection of human rights offered by EU law fall short of the standard required for effective judicial protection.

Furthermore, not all EU action is reviewable. This gap is most notable in the area of the Common Foreign and Security Policy where the CJEU may review acts only in terms of competence, or when they are restrictive measures against individuals. No general jurisdiction to annul exists over the CFSP. That is regrettable given that this area of EU action has an intensive interplay with human rights given that it concerns acts taken in areas under conflict, with vulnerable populations.

Consequently, one has to turn to alternatives for challenging the legality of a Union action vis-àvis human rights (this has been discussed in detail in Chapter 3). The preliminary reference procedure under Article 267 TFEU and the plea of illegality under Article 277 may be paths to bypass the problems posed by the stringent standing prerequisites. The preliminary reference procedure allows for a national court to require a ruling by the CJEU on the validity of a Union act. However, the preliminary reference procedure is not an action brought directly by a person but is instead dependent on the decision of the national court. The plea of illegality, on the other hand, is not an autonomous cause of action. Applicants cannot use it unless they are involved in another dispute before the CJEU, which is not always the case.

As an alternative for the lack of jurisdiction of the CJEU over CFSP actions as well as the gap left behind by non-accession, another solution is the establishment of specialized bodies that examine the compatibility of action of specific bodies or agencies of the Union, with human rights. Such examples include the EULEX Human Rights Panel in Kosovo and the Fundamental Rights Officer in FRONTEX. While these mechanisms are useful and have an important role to play in the protection of human rights, they are not courts. They cannot create a uniform jurisprudence with a wider application. What is more, they offer piecemeal protection in specific cases and cannot possibly make up for the fundamental drawbacks in the EU's legal system.

Question 2: Are the principle of non-contractual liability and the action for damages provided for by Article 340 TFEU an effective mechanism and legal remedy, accordingly, for human rights violations? 
Answer: The principle of non-contractual liability is the most fertile ground of EU law for the remedying human rights violations within the judicial system of the $\mathrm{EU}$ in respect of violations of human rights by the EU, its institutions, bodies or agencies. Despite the usefulness of the principle and the relevant procedure provided for by Article 340 TFEU, the interpretative methods of the CJEU as well the scope of application of the principle to the various areas of $E U$ action, limit the effectiveness of this legal remedy.

\section{Reasoning:}

The action for damages provided by Article 340 TFEU encompasses two important aspects. Firstly, it reviews the legality of a Union act. Secondly, if unlawfulness is found, the Court awards damages, which are a remedy for the harm the unlawfulness caused. This action can therefore be used in the context of human rights.

This is visible in practice. The infringement of a Charter right has been expressly recognised by the CJEU as a ground for claiming damages for non-contractual liability. ${ }^{1}$ Article 51(1) of the Charter specifically states that the provisions of the Charter are addressed to the institutions, bodies, offices and agencies of the Union and that these shall respect the rights and principles of the Charter. An applicant may base their non-contractual liability claim on rights contained in the Charter. This possibility was highlighted by the CJEU in Groupe Gascogne SA v European Commission $^{2}$ and the GCEU in Gascogne Sack Deutschland GmbH v European Commission. ${ }^{3}$

There are, however limitations. Not all damages actions based on rights violations are successful - the requirement of unlawfulness is subject to interpretation by the Court which may use its interpretative methods to dismiss an action. In Ledra Advertising, ${ }^{4}$ for example, the claimants brought an action for damages against the Commission and the European Central Bank for the

\footnotetext{
${ }^{1}$ Case C-58/12 P Groupe Gascogne SA v European Commission [2014] 4 CMLR 14 and Case C-40/12 Gascogne Sack Deutschland GmbH v European Commission [2014] 4 CMLR 12.

${ }^{2}$ Ibid.

${ }^{3}$ Ibid.

${ }^{4}$ Joined Cases C-8/15 P to C-10/15 P Ledra Advertising Ltd and Others v European Commission and European Central Bank (ECB) Judgment of the Court (Grand Chamber) of 20 September 2016 ECLI:EU:C:2016:701 this decision can be contrasted to Joined Cases C-105/15 P to C-109/15 P. Konstantinos Mallis and Others $v$ European Commission and European Central Bank (ECB) Judgment of the Court (Grand Chamber) of 20 September 2016 ECLI identifier: ECLI:EU:C:2016:702 which was issued on the same date with the same subject matter, but concerned an annulment procedure under Article 263 TFEU, where the Court decided that the actions of the Commission within the framework of the ESM are not reviewable EU acts.
} 
Memorandum of Understanding adopted in 2013, which imposed direct cuts from individuals' deposits in banks in order to stabilise the country's banking sector. The claimants' position was that this MoU was in violation of Article 17(1) of the Charter, protecting the right to property. The CJEU's decision was that the restrictions of the right were proportional to the aim to be achieved; the latter being the avoidance of a spill-over effect to other banks or even the economies of other Member States. As such, the claim was dismissed as the restriction was deemed lawful. While this case is an example of the use of this principle as a path towards claiming one's rights, the position of the CJEU in essence brings forward the idea that the core of the EU's objective is the protection of economic interests.

It is significant to understand that in the context of the non-contractual liability procedure, a finding of unlawfulness in all human rights cases is determined on pure human rights terms. Regardless whether the act in question is taken after the exercise of discretion or not, the Courts will determine the unlawfulness on the basis of the prescribed scope of that right and on whether the limitation to the relevant right may be justified on human rights terms, such as proportionality and the protection of public interests.

Over the years, the CJEU has developed criteria for the satisfaction of a claim for damages that are stricter to those examined by national courts in public authority liability cases. The 'but for test' is not sufficient in damages actions against the Union. Therefore, although the immediate victim of the human right violation may be able to prove the material or non-material damage, Article 340 does not generally allow indirect claims.

Furthermore, moral damage is another aspect of human rights claims that on the basis of the case law is difficult to be proven. ${ }^{5}$ Where the applicant requests compensation for moral, and thus non-quantifiable damage, the applicant must at the very least prove that the conduct in question was grave enough to cause that damage. While this in principle allows claims for moral damage which may exist in human rights-related cases, the wording of the CJEU is restrictive, thus crippling the procedure's effectiveness in protecting human rights.

\footnotetext{
${ }^{5}$ Case C-481/07 P Selex Sistemi Integrativ. Commission ECLI:EU:C:2009:191.
} 
The CJEU has traditionally taken a restrictive approach as to the nature of damage. The CJEU does not award nominal damages under the Article 340 procedures - this may be a drawback in the effective protection of fundamental rights given that often the compensation sought after in those cases is the mere recognition of a violation. The CJEU however, will not allow a noncontractual liability claim unless all three requirements of causation, damage and unlawfulness are fulfilled and neither will it issue declaratory judgments in this context. The finding of a violation is not sufficient for the claim to be successful and limits the role that Article 340 may have as a procedure for the recognition of a human rights violation.

Nevertheless, the fact that the CJEU has in some cases recognised that the violation may be grave enough so as to require more than the declaration of unlawfulness in order to be compensated, ${ }^{6}$ is a positive development which may gradually shift the understanding of the EU judiciary so as to grant damages for the violation of the right per se. This would constitute the non-contractual liability procedure more effective as a vehicle for human rights claims.

Another question is whether remedies could be obtained for violations caused by lawful acts. In FIAMM ${ }^{7}$ the Court seemed to suggest that where the application of a legislative measure could lead to disproportional application of the rights to property or the freedom to pursue a trade or profession, no-fault liability could arise. The Court in FIAMM introduces these rights as something inherent in every legal or natural person regardless of existing right-conferring rules. However, given the post-Lisbon dimension of rights in EU law, these rights are not only inherent but indeed expressly recognised and create binding obligations upon EU institutions. Consequently, in FIAMM the CJEU establishes an exception which appears to be only for the sake of discussion.

Nevertheless, this opens up a new perspective: the bindingness of human rights on the EU's institutions is even more important because it will allow applicants who, as in FIAMM or Dorsch would invoke the difficult claim of liability for lawful acts when they would be unable to identify a legal rule that binds EU institutions, to bring forward a rights-based claim of unlawfulness. The

\footnotetext{
${ }^{6}$ Case T-577/2014 Gascogne Sack Deutschland GmbH and Gascogne v European Union Judgment of the General Court (Third Chamber, Extended Composition) of 10 January 2017.ECLI:EU:T:2017:1, Case T-384/11 Safa Nicu Sepahan Co. $v$ Council of the European Union ECLI:EU:T:2014:986.

${ }^{7}$ Joined Cases C-120/06 and C121/06 FIAMM and Others v. Council and Commission Joined Cases [2008] ECR I06513.
} 
disproportional restriction of a right is sufficient unlawfulness since the EU's institutions are bound by fundamental rights obligations. It is possible that the Court's proposed exception in FIAMM is not even necessary to be developed today.

A drawback of this procedure is that the scope of application of the principle of non-contractual liability is unclear. Much depends on a case- by-case basis. In Ledra Advertising, ${ }^{8}$ the court was called upon to clarify whether the acts of the Commission and the ECB within the ESM could be subject to an action for damages, despite the general provision of Article 340(2) that the Union shall make good any damage caused by its institutions or by its servants. This was in light of the fact that the decision-making was made in tandem with other institutions not belonging to the EU. The examples of the FRONTEX and Europol Regulations discussed above may be significant developments in that they provide for bodies which may violate human rights to be accountable, yet they demonstrate the piecemeal approach taken by the Union in establishing the rules for liability of its institutions.

There is no express provision in the Treaties or the case law whereby the CJEU is conferred jurisdiction to rule on matters of CFSP within the framework of the non-contractual liability procedure. There is a lack of holistic application of the obligation of the Union to provide effective judicial protection, which is part of fundamental rights. Article 47 of the Charter of Fundamental Rights provides that every person whose rights are violated is entitled to an effective remedy before a competent tribunal. This provision binds the Union in respect of its own activities and judicial system as well. It therefore appears that this gap in the jurisdiction of the Union judicature is not easily reconciled with this important obligation.

Question 3: What are the possibilities of obtaining remedies of human rights violations by the EU by engaging the latter's responsibility as an international legal person?

Answer: The EU may not be effectively held accountable for human rights violations within the framework of international law, owing to the absence of an international human rights treaty covering a wide range of human rights binding the Union, and procedural

8 Joined Cases C-8/15 P to C-10/15 Ledra Advertising Ltd and Others v. European Commission and European Central Bank P ECLI:EU:C:2016:701. 


\section{obstacles hindering the accountability of the EU before international fora, thus rendering the obtention of remedies in international law theoretical, yet desirable.}

\section{Reasoning:}

The EU could only possibly breach its international human rights obligations arising out of jus cogens. Firstly, the EU is not formally bound by any multilateral human rights instrument apart from Convention on the Rights of Persons with Disabilities, which was ratified in 2010. The attempt to accede to the European Convention on Human Rights was aborted by Opinion 2/13, marking a failure of the EU to integrate an international human rights instrument into its internal law and to harmonise EU law with the possibility of international human rights obligations. This has left the EU in a limbo in terms of fulfilling its obligations according to Article 6(2) TEU, while it exposes EU activity to indirect review. ${ }^{9}$ What is thus far clear is that the Union is bound by the minimum standard of human rights obligations that has so far been accepted to be guaranteed by peremptory norms.

Therefore, it becomes evident that the EU has no express or binding international obligation to respect human rights beyond the ones guaranteed by peremptory norms which include the prevention of racial discrimination, the prohibition of torture, slavery, aggression and genocide, ${ }^{10}$ or the rights of persons with disabilities. This is not without significance, given that the assumption that the EU is bound by jus cogens generates obligations to respect these rules, owed to the international community as a whole. ${ }^{11}$

Nevertheless, the EU is not formally bound to respect, at an international level, other rights beyond the ones included in peremptory norms. For example, the right to private life, the right to property, the freedom of association do not belong to the norms that fall under the umbrella of jus cogens at an international level. The EU's international obligations as regards these remain, at least from an international law viewpoint, unclear.

\footnotetext{
${ }^{9}$ Bosphoros Hava Yollari Turizm Ve Ticaret Anonim Sirketi v. Ireland (App No. 45036/98) ECtHR 30 June 2005 (2006) 42 EHRR 1.

${ }^{10}$ Barcelona Traction, Light and Power Company, Limited (Belgium v. Spain), Second Phase, Judgment of 5 Feb. 1970 [1970] ICJ Rep 3.

${ }^{11}$ General Comment No. 31, 26 May 2004, Human Rights Committee, CCPR/C/21/Rev.1/Add13.
} 
Despite the fact that the Charter of Fundamental Rights includes the abovementioned ${ }^{12}$ (and many other) rights, such qualified rights are not part of customary international law. The internal recognition of certain human or fundamental rights by Union law does not guarantee that the Union is accountable for their violations on the international plane, leaving an important void in the substantive protection of human rights against arbitrary Union action within the area of international law.

As the EU is an international organisation which may act only through its institutions, bodies, offices, agencies and servants, its responsibility will be established by proving attribution. However, the rules of attribution for the responsibility of international organisations remain a developing area of international law, with few concrete legal sources on the matter, while the ARIO are not binding.

It is also unclear how to engage EU's international responsibility where a Member State violates human rights guaranteed by an international agreement to which it is a party, but that is done on the basis of EU obligations. The Union may be found to violate its international human rights obligations not only where it is acting beyond its own territories or in the context of external action, but also where Member States or agencies under its control are implementing its policies. International obligations permeate the implementation of policies and thereby rules and conduct of domestic institutions. While substantive human rights may arise when Member States are implementing EU policies, there is an absence of an international forum where the Union could be held responsible instead of, or along with, the implementing Member State. Accession of the EU to the ECHR, would be a solution, as it would provide for a co-respondent mechanism whereby both the EU and the Member State could be held responsible.

Bringing the EU before an international legal forum is an exceedingly theoretical concept, since not only has the EU expressed reluctance for its policies to be reviewed by any external bodies, ${ }^{13}$ but also its human rights obligations in international law are not sufficiently defined. The theoretical engagement of the EU's international responsibility for international human rights law violations could offer improved access to remedies for potential victims.

\footnotetext{
${ }^{12}$ Article 7 of the EU Charter protects the right to private and family life; Article 17 of the EU Charter guarantees the right to property; Article 12 guarantees the freedom of assembly and association.

${ }^{13}$ Opinion 2/13: Opinion of the Court (Full Court) of 18 December 2014.
} 
Public international law has a system of remedies - restitution, compensation and satisfaction that are well suited to cases related to human rights violations. This is also evident from the discussion on the remedies available within the remit of the ECtHR. This is contrasted to the system of remedies available within the EU's legal order, with more stringent criteria for the establishment of responsibility or illegality and the obtention of the remedy sought, such as annulment or damages.

Consequently, the establishment of the EU's international responsibility for human rights violations would be a very positive step towards victims obtaining the appropriate remedy for the harm they have suffered even if that can only be substantiated as the violation of a right. Naturally this remains on a very theoretical level given that Resolution 60/147, dealing with remedies, and the ARIO are not binding despite their elaborate development and authoritative character.

This possibility stumbles over another enormous obstacle. That is the existence of a legal forum, an institution which would apply the rules on the international legal responsibility of international organisations and by extent the EU. As there is no universally accepted regime for the rules applicable to the responsibility of international organisations, the EU's external accountability is further undermined. Even the enforcement of peremptory norms in the case of the Union is again a very hypothetical scenario, since the Union cannot be brought before any international legal forum for the violation of peremptory norms.

This enforcement of human rights obligations could be supported where the Union makes arrangements for informal cooperation with human rights monitoring bodies, as it has been in the case of the Geneva Convention on Refugees, ${ }^{14}$ yet such arrangements do not substitute judicial control. This additionally underlines the need for the EU to accede to an international human rights instrument. The creation of alternatives to external review by specialised bodies, such as the Human Rights Review Panel in EULEX would be a way to ensure, at least fragmentally, the Union's responsibility for the violation of international human rights norms.

\footnotetext{
${ }^{14}$ Exchange of letters between the United Nations High Commissioner for Refugees and the European Commission, of 15 February 2005, available at: <http://www.unhcr.org/refworld/docid/42135cba4.html.>.
} 
The lack of external responsibility and obligations accentuates the 'parallel' way in which EU human rights law develops through the Charter and the CJEU's jurisprudence, as compared to international human rights law. The risk is establishing a two-tier system, which could strike at the heart of the universality that ought to characterise human rights, and that any disparity in the protection offered by the two regimes will in effect undermine the EU's credibility towards third states and other international organisations. ${ }^{15}$

\section{Proposals}

\section{A. The CJEU's jurisdiction must be expanded to comprise all areas of Union action and all EU agencies, bodies and institutions}

It is evident that the jurisdiction of the CJEU for judicial review claims and damages claims is insufficient. The CJEU lacks a general jurisdiction over the CFSP thus not allowing victims of human rights violations to bring claims in relation to acts and deeds that are committed by the Union's representatives, bodies and agencies within that framework. Similarly, even the action of EU institutions within the framework of the ESM was excluded from the CJEU's jurisdiction for judicial review cases, ${ }^{16}$ and the EEAS is in a grey area as to its accountability. ${ }^{17}$

The legal rules relating to the extraterritorial obligations of the EU to comply with EU norms are also rudimentary and insufficient ${ }^{18}$ to clarify how accountability may arise in the complex international sphere it acts in. In the context of non-contractual liability it is not fully certain which bodies, institutions or agencies are in fact under the jurisdiction of the CJEU, leaving often jurisdiction to be awarded by the legislation establishing the relevant body. ${ }^{19}$ Whether

\footnotetext{
${ }^{15}$ European Regional Office of the United Nations' High Commissioner for Human Rights Report, 'The European Union and International Human Rights Law' <http://www.europe.ohchr.org/Documents/Publications/EU_and_International_Law.pdf $>$.

16 C-109/15 P Konstantinos Mallis and Others v European Commission and European Central Bank (ECB) Judgment of the Court (Grand Chamber) of 20 September 2016 ECLI identifier: ECLI:EU:C:2016:702.

${ }^{17}$ B. van Vooren, 'A Legal Institutional Perspective on the European External Action Service' (2011) 48 CMLRev 475-502, 500-501.

${ }^{18}$ Case C-347/10 Salemink v Raad van Bestuur van het Uitvoeringsinstituut Werknemersverzekeringen [2012] 2 CMLR 6

19 Article 27, Regulation (EU) No 526/2013 of the European Parliament and of the Council, of 21 May 2013 concerning the European Union Agency for Network and Information Security (ENISA) and repealing Regulation (EC) No 460/2004, Article 24 Regulation No 1077/2011 of the European Parliament and of the Council of 25 October 2011 establishing a European Agency for the operational management of large-scale IT systems in the area
} 
CFSP measures may be the subject matter of the actions for annulment is yet unclear with the CJEU demonstrating some willingness for this inclusion in some decisions, ${ }^{20}$ but not accepting such jurisdiction expressly. ${ }^{21}$ The Advocate General's Opinion in Opinion 02/13 negates any such jurisdiction.

The necessity to protect human and fundamental rights calls for a substantive reform - the inclusion of all areas of Union action and all levels and facets of the Union's personality in the jurisdiction of the CJEU. This would be a true breakthrough that would constitute the CJEU a judicial forum that truly scrutinises Union action and therefore, a court where individual applicants would have the ability to challenge Union action for violations of human rights.

\section{B. The CJEU ought to become more open to human rights claims through its case law}

The analysis of the mechanisms for the EU's accountability within its legal and judicial system have revealed a reluctance on the part of the CJEU accord the criteria of Article 263 and Article 340 TFEU an interpretation that would be encouraging and open to human rights actions. The CJEU ought to move further than its hard-lined interpretative methods and allow more opportunities for human rights claims to be substantially heard and remedied.

The strict interpretation of standing criteria is hostile to individual applicants. In reality, it deprives individual applicants of their most fundamental right; the ability to have access to justice. This calls for the relaxation for the standing criteria, particularly in light of the increasing human rights issues that may arise as the EU is becoming more active in every field of competence.

The procedure of Article 340 TFEU is an opportunity for the CJEU to expand the protection it offers to human rights by recognising that unlawfulness in human rights claims cannot be distinguished depending on whether an act is discretionary or not, given that the limitation of a right constitutes unlawfulness regardless of whether the measure entailed discretion. This would

of freedom, security and justice, Regulation 45/2001, Council Decision 2009/371/JHA of 6 April 2009 establishing the European Police Office (Europol).

${ }^{20}$ Case T-341/07, José Maria Sison v. Council [2011] ECR II-07915, Case T-292 Mugraby v. Commission and Council [2012] ECR II- 00255.

${ }^{21}$ Opinion 2/13: Opinion of the Court (Full Court) of 18 December 2014, paras 249-255. 
be based on the fact that human and fundamental rights cases are decided on their own terms. Furthermore, it would be a positive development in EU human rights law if the CJEU embraced the notion that the finding of unlawfulness in human rights cases, which is in effect the finding of a violation, entails in itself damage to the person who has suffered the violation. Such a step forward would truly constitute the non-contractual liability principle as a mechanism for the protection of human rights and the remedying of their violations by Union acts.

\section{The EU ought to accede to more international human rights instruments and accept the jurisdiction of their compliance mechanisms}

The analysis of the second Part of the thesis reveals an imperative exigency; namely that the EU must accede to an international human rights instrument. The lack of such express human rights obligations is not suitable to the role that the EU is assuming on the international scene. This void has as a consequence, that the EU in the current legal framework may not be held accountable before any international legal forum for the violations of even the most basic of human rights guaranteed by peremptory norms. The accession to such an international instrument must be accompanied with the relevant modalities given that the EU is not a state but an international organisation.

The most evident and desirable option for the EU is the accession to the European Convention on Human Rights. However, consequence of Opinion 2/13, is that alternatives must be sought for accession to take place. The options for the way forward are limited; an extreme option would be the amendment of the EU's Treaties or Accession. ${ }^{22}$ A more realistic option that would be the best to pursue, is the re-negotiation of the Accession Agreement in light of these concerns voiced by the CJEU. ${ }^{23}$ Any renegotiation must however always take into account that the objective of an accession is indeed to make the EU subject to the same external control as States parties to the Convention.

\section{Arrangements should be made by establishing specialist bodies or cooperating with international institutions to establish the EU's accountability with regard to its human}

\footnotetext{
${ }^{22}$ T. Lock, 'The future of the European Union's accession to the European Convention on Human Rights after Opinion 2/13: is it still possible and is it still desirable?' (2015) 11(2) ECLR 239, 253.

${ }^{23}$ B. de Witte and S. Imamovic, 'Opinion $2 / 13$ on accession to the ECHR: defending the EU legal order against a foreign human rights court' (2015) ELR 695 - 697.
} 
rights obligations, in light of the lack of a set of international human rights obligations for the EU and the inadequate jurisdiction of the CJEU

In light of the above observations that there are no mechanisms for the external accountability of the Union, in particular with resapect to the CFSP and that even the Union's judicial order is often lacking the competence to examine human rights matters falling outside its jurisdiction, alternatives must be sought.

The European Office of the UN's High Commissioner for Human Rights has suggested that the EU may create informal arrangements with international human rights treaties monitoring bodies. ${ }^{24}$ In its Report, the Office gives the examples of the Cotonou Agreement, for which the Union has struck up an agreement with the Human Right's Council High-Level Task force, to evaluate the Cotonou Agreement regarding the implementation of the right to development, ${ }^{25}$ or the arrangement that has been set up regarding the EU's compliance with the Geneva Convention on Refugees through which the Union will exchange information regarding asylum matters with the UN's High Commissioner for Refugees. ${ }^{26}$ These are positive examples which, by no means being a holistic solution, may be followed regarding other instruments.

Another solution, which may partly rectify the gap in the CJEU's jurisdiction over all EU action, is the enhancement of bodies that deal with human rights related complaints within the context of particular agencies or activities, even if these may fall outside the CJEU's jurisdiction. An example is the Human Rights Review Panel of EULEX, the EU's mission in Kosovo, which examines complaints regarding human rights against the mission. ${ }^{27}$ This panel has been very active and issued several decisions, including follow - up decisions for the implementation of recommendations made. In light of the absence of general jurisdiction of the EU courts over CFSP/CSDP acts and the problems of extraterritoriality, the establishment of the Human Rights

\footnotetext{
${ }^{24}$ European Regional Office of the United Nations' High Commissioner for Human Rights Report, 'The European Union and International Human Rights Law', $\quad$ p. 13 <http://www.europe.ohchr.org/Documents/Publications/EU_and_International_Law.pdf> p. 32

${ }^{25}$ High-Level Task Force on the Implementation of the Right to Development, 'Technical Mission Report: Cotonou Partnership Agreement between the European Union (EU) and African, Caribbean and Pacific (ACP) countries', UN Doc. A/HRC/8/ WG.2/TF/CRP.4, 28 December 2004.

${ }^{26}$ Exchange of letters between the United Nations High Commissioner for Refugees and the European Commission, of 15 February 2005, available at: <http://www.unhcr.org/refworld/docid/42135cba4.html. > Accessed 25 February 2016.

${ }^{27}$ Human Rights Review Panel <http://www.hrrp.eu/relevant-rights.php〉
} 
Panel is indeed an effective alternative to the judicial review procedure in terms of ensuring accountability for EU acts that may affect human rights. Another example of an alternative is the Complaints Mechanism ${ }^{28}$ and the Fundamental Rights Officer of Frontex. ${ }^{29}$ The Fundamental Rights Officer monitors human and fundamental rights matters that may arise within the context of Frontex activity.

\section{Final Observations}

What is certain is that in a world where human dignity remains a notion to be conquered, despite the developments over the last two centuries, efforts are still needed for truly protecting the rights of the person. It therefore remains to be seen to what extent the EU will take human rights a step forward by assuming responsibility in an effective and holistic manner and engaging in the protection of human rights, so as to ensure that victims of such violations have access to the necessary remedies.

${ }^{28}$ Regulation (EU) 2016/794, Article 72.

${ }^{29}$ Regulation (EU) 2016/794, Article 71. 



\section{IMPACT PARAGRAPH}

In the current social, political and economic climate, the European Union has become a global actor. The rapid development of EU policies permeates every sector of society and economic activity, from environmental standards, to competition regulation or economic measures with effects on individuals. Simultaneously, the political and economic crises of the last decade or so, followed by the United Kingdom's departure from the Union and the coronavirus pandemic, were sequential shocks that have challenged the Union's existence, casting doubts as to the organisation's credibility and democracy.

It is possible that, as with any exercise of authority, EU action may at times transgress the limits set by human rights standards, including the EU Charter of Fundamental Rights and international law. The risk is evident in policy areas like the Union's sanctions against persons in the framework of its Common Foreign and Security Policy, the management of the refugee crisis through the external borders policy, issues of police cooperation, as well as judicial and prosecution cooperation. Where EU action is related to the freezing of an individual's assets, the cutting of their deposits, or the execution of an arrest warrant them, guarantees for the affected person's rights must exist. If the rights have been violated, a remedy must be provided.

However, while the Union claims to abide by human rights standards, and also passes legislation and acts that aim at the protection of human rights at Member State level, the legal regime for remedies for human rights violations committed by the EU and the degree of its engagement by international human rights standards, is yet unclear. For example, while the EU has its own Charter of Fundamental Rights, it is not a party to any multilateral human rights treaty apart from the United Nations Convention on the Rights of Persons with Disabilities.

The overarching theme of this book is the vertical relationship between EU institutions and affected individuals. This book examines how the Union's legal responsibility for violations of human rights may be engaged effectively, with the purpose of achieving the substantive remedying of the violation and the rectification of the harm suffered by the victim. The approach is to take a path starting with the problems observed, leading towards the solutions that may be 
applied. This methodology allows readers to familiarise themselves with the main topics that dominate the EU human rights discourse, before exploring more nuanced alternatives.

In this spirit, Part I begins by explaining the most substantial deficits in the applicable framework for the challenge of Union action on human rights grounds. Firstly, it explores the non-fulfilment of the EU's accession to the European Convention on Human Rights and the limited effectiveness the procedure of annulment of EU acts has for individual applicants. Furthermore, it delves into legal alternatives such as the doctrine of direct effect, preliminary references, the plea of illegality and complaints mechanisms for specialised bodies or agencies of the EU.

The deficit that exists is simple to visualise. Let us imagine that a person wishes to challenge an action, enforced by an authority of an EU Member State. They claim it has led to the deprivation of their property and disrupted their family life. The competent authority of the Member State had no option but to enforce an EU obligation, and the case is argued until that Member State's highest court. The Member State is also a party to the European Convention of Human Rights, so this person considers a case before the European Court of Human Rights for the violation of their rights to property and family life. Through this application, they may seek vindication of their rights, restitution and just satisfaction for the damage sustained. However, as the EU is not party to the Convention, the European Court of Human Rights, will have simply no capacity to examine the compatibility of the EU act that triggered the alleged violation and they realise that they have enountered an impasse.

The same person therefore considers challenging the same EU act directly before the Court of Justice of the European Union. They believe that the act was contrary to their rights to property and family life, protected within the EU legal order, and thus must be annulled. Alas; things are not so simple. If the EU act was not directed specifically to this applicant, the odds are that they will have no standing to challenge it.

They therefore have to look into other alternatives. They examine several options; one could be to file a case in a national court and bring up the issue of compatibility of the action with fundamental rights, through a preliminary reference. Another possibility is to continue with their 
efforts before the Court of Justice of the European Union, and where the measure is of general application, incidentally claim its illegality.

As these scenarios are legally intricate, a simpler alternative is to examine whether the action in question originates from a specialised agency or body of the Union. In that case, they may use that body or agency's independent complaint procedures instead of going to court, provided that such a mechanism is indeed in place. That is not always the case.

Part II concentrates on the important, substantive remedy of compensation, through the application of the principle of non-contractual liability. This issue is analysed specifically vis-àvis human rights cases, while also making a comparison with national law and the jurisprudence of the European Court of Human Rights.

In this scenario, the person in question opts for claiming damages before the Court of Justice of the European Union for harm they suffered due to the act of the Union's institutions or servants. They claim that the damage caused is the deprivation of property and the consequent violation of their private and family life. To that end, they must prove that the action in question has been unlawful, and that is has caused the alleged identifiable damage. Their claim may be that the violation of their right entitles them to compensation as such. Again however, complex legal questions inevitably arise. Can the violation of a right be identifiable damage? If that is true, are all acts with the ultimate effect of disproportionately limiting a fundamental right be unlawful on the basis of their consequences? If the violation of a right is in itself damage, how can it be quantified to award compensation? This Part addresses all of the above questions to assess whether non-contractual liability is fertile ground for obtaining a remedy at EU level.

Part III goes a step beyond the EU's legal system. It examines the possibility of obtaining remedies for violations of human rights by the EU in the sphere of international law, both as an alternative to the EU's legal system as well as potential additional protection.

Under this framework, the potential litigant is determined to hold the EU accountable at an international level for the act that caused the alleged violation of their human rights. After all, the $\mathrm{EU}$ is an international organisation founded on the principles of international law. During such an effort, they will encounter even greater obstacles than within the EU's legal system. Given 
that the EU is not party to a multilateral human rights instrument except the Convention of the Rights of Persons with Disabilities, a significant problem is the identification of other international human rights norms may bind the EU when acting as an international legal person. Is it possible that certain customary international law rules apply to all legal persons be they state or non-state entities, including the EU? In that case, before which international legal forum can a non-state entity be held responsible to provide remedies for violations of rights guaranteed by customary international law? If such a procedure is possible, what are the modalities of establishing responsibility and obtaining a remedy? By addressing these theoretical yet substantial matters, the book also touches on another topical issue; the question of human rights obligations of non-state entities in an era of institutionalisation of the international community.

Addressing the issues above is necessary, as academic discourse has often steered clear of the question of enforcement of human rights norms vis-à-vis the EU. Instead, focus has been diachronically been put on human rights as part of the EU legal order. Rather, the book takes a more pragmatic approach. The book aims to be, apart from a contribution to the academic discourse surrounding the relationship between the EU and human rights, a detailed and informed handbook for the individual or the advocate who in effect encounters the difficult challenge of bringing a claim against an EU organ for violating human rights.

In that framework, it contains a comprehensive analysis of substantial and procedural, EU and international, law. The book includes references to a significant body of case law and explains methods of initiating procedures and obtaining interlocutory relief before courts or extrajudicial bodies. It also addresses the thorny subject of enforcing remedies and executing judgments of the competent courts or bodies, following findings of human rights violations. The institutions examined include, inter alia, the Court of Justice of the European Union, the European Court of Human Rights as well as specialised complaints procedures such as the EULEX Panel for the EU's Mission in Kosovo. Consequently, the book maps out various options available for bringing a human rights claim against the EU, while assessing the remit, role and effectiveness of the applicable rules in each case.

The content of the research may be particularly useful for policy makers such as legislators and other important stake-holders in the decision-making procedure, including experts, NGOs, or 
even human rights activists. In addition, the book does not only state the conclusions reached throughout the research - which are, inevitably, that important deficits exist for access to justice for individual applicants. The book also suggests solutions to problems that are identified. For example, the thesis strongly advocates the accession of the EU to the European Convention on Human Rights, as well as the creation of a clear and binding system of remedies for international organisations within international law.

The published book will be available to be read by researchers, students, academics and practitioners as well. It is therefore possible for the thesis to be available at libraries at Universities, courts and government institutions across the European Union. This book can be introduced to university libraries while also form part of academic curriculum in undergraduate or postgraduate degrees, due to its comprehensive approach to significant European Union law questions. 



\section{BIBLIOGRAPHY}

\section{Books, Contributions in Books and Articles}

Ahlborn C., 'The Rules of International Organisations and the Law of International Responsibility', (2011) vol. 8International Organisations Law Review, 397.

- - 'The Use of Analogies in Drafting the Articles on the Responsibility of International Organisations. An Appraisal of the 'Copy-Paste Approach', (2012) vol. 9, International Organisations Law Review 53.

Albors-Llorens A., 'Sealing the fate of private parties in annulment proceedings?' The General Court and the new standing test in article 263(4) TFEU' (2012) 71(1) Cambridge Law Journal 52.

_ _ 'Remedies against EU institutions after Lisbon - an era of opportunity?' (2012) 71(3), Cambridge Law Journal 532.

Alonso García R., 'The General Provisions of the Charter of Fundamental Rights of the European Union', (2002) 8, European Law Journal 492.

Alston P. (ed), The EU and Human Rights (Oxford University Press 1999).

— — and Weiler JHH., 'An 'Ever Closer Union' in Need of a Human Rights Policy: The European Union and Human Rights', in Alston (ed) The EU and Human Rights, (OUP 1999).

_ _ The European Union and Human Rights: Final Project Report on an Agenda for the Year $2000^{\prime}$.

Amerasinghe C.F., 'Comments on the ILC's Draft Articles on the Responsibility of International Organisations', (2012) vol. 9 International Organisations Law Review 29. 
Amerasinghe C.F., Principles of the Institutional Law of International Organisations, (2nd ed, CUP 2005).

Anagnostaras G., 'Solange III? Fundamental rights protection under the national identity review,' (2017) 42(2) ELR 234.

Arend K., 'EC Liability in the Absence of Unlawfulness, The FIAMM Case', (2009) 1 Gottingen Journal of International Law 199.

Arnull A., 'April Shower for Jégo-Quéré', (2004) 29 ELR 287.

Bartels L., 'The EU's human rights obligations in relation to policies with extraterritorial effects', (2014) 25(4) EJIL 1071.

Bas Arts 'Non-State Actors in Global Governance: Three Faces of Power', (Bonn, Working Paper 2003/4) Max Planck Project Group on Common Goods.

Bassiouni M.C., 'The Normative Framework of International Humanitarian Law: Overlaps, Gaps and Ambiguities,' (1998) 8 Transnational Law and Contemporary Problems 199.

Beatson J. and Tridimas T. (eds.), New Directions in European Public Law (Hart, 1998).

Beaucillon C., 'Opening up the horizon: the ECJ's new take on country sanctions' (2018) 55(2), CMLRev 387.

Bell C., 'Reassessing multiple attribution: The International Law Commission and the Behrami and Saramati decision', (2010) 42 New York University Journal of International Law and Politics 501. 
Berg A., 'The EU's Experience with Security Sector Governance', (2011) United States Institute of Peace Special Report 265.

Berger V., 'Le règlement amiable devant la Court' in Pettiti L.-E., Decaux E and Imbert P-H. (eds) La Convention européenne des droits de l'homme. Commentaire article par article (Paris: Economica, 1999).

Bergstrom C.F. 'Defending restricted standing for individuals to bring direct actions against "legislative" measures' (2014) 10(3) ECL Review 481.

— - and Ritleng D., (eds) Rulemaking by the Commission: The New System (OUP, 2015).

Bering Liisberg J., 'Does the EU Charter of Fundamental Rights Threaten the Supremacy of Community Law?', (2001) 38 CMLRev 1171.

Besselink L.M.F., 'The Member States, the National Constitutions and the Scope of the Charter', (2001) 8 Maastricht Journal of European and Comparative Law 68

- - 'Acceding to the ECHR notwithstanding the Court of Justice Opinion 2/13' (December 23, 2014), <http://www.verfassungsblog.de/en/acceding-echr-notwithstanding-court-justice-opinion213/\#.VNzHdPVm670>

_ _ 'The parameters of constitutional conflict after Melloni', (2014) 39(4) ELR 53.

Bianchi A., 'Human Rights and the Magic of Jus Cogens' (2008) 19 EJIL 491.

Bindschedler R., 'Die Anerkennung im Volkerrecht' (1961-1962) 9 Archiv des Völkerrechts 377.

Biscop S., 'Permanent Structure Cooperation and the Future of ESDP: Transformation and Integration' (2008) 13 European Affairs Review 431. 
Boutin B., 'Responsibility of the Netherlands for the acts of Dutchbat in Nuhanovič and Mustafič: the continuous quest for a tangible meaning for "effective control" in the context of peacekeeping' (2012) 25(2) Leiden Journal of International Law 521.

Boven T., 'The right to restitution, compensation and rehabilitation for victims of gross violations of human rights and fundamental freedoms' in Alfredsson G. (ed), The living law of nations (Khel am Rhein, Engel, 1996).

Breuer M., 'Zur Anordnung Konkreter Abhilfemafinahmen Durch den EGMR: Der Gerichtshof Betritt Neue Wege im Fall Asanidse Gegen Georgien’ (2004) 31 Europäische Grundrechte Zeitschrift 257.

Brkan M., 'The Role of the European Court of Justice in the Field of Foreign and Security Policy after the Treaty of Lisbon: New Challenges for the Future', in Cardwell P.J. (ed), EU External Relations Law and Policy in the Post-Lisbon Era (The Hague: T.M.C. Asser Press, 2012).

Broberg M., 'The calculation of the period of limitation in claims against the European Community for non-contractual liability' (2001) 26 ELR. 275.

_ _ 'Preliminary References as a Means or Enforcing EU law' in Jakab A. and Kochenov D., The Enforcement of EU law and values, (OUP 2016).

Bulterman M. in de Schutter O. and Alston P. (eds) Monitoring Fundamental Rights in the EU The Contribution of the Fundamental Rights Agency (Hart 2005).

Burchill R., 'Assessing the European Union's Position on Human Rights: Is it a Desirable One?' in Wetzel J., (ed) The EU as a 'Global Player' in Human Rights? (New York, Routledge 2011).

Butler G., 'The coming of age of the court's jurisdiction in the common foreign and security policy’ (2017) 13(4) ECLR 673. 
Cabral Barreto I., 'Le règlement amiable devant la Cour européenne des droits de l'homme' (2002) Bulletin des droits de l'homme 10.

Caflisch L., 'La mise en oeuvre des arrets de la Cour: Nouvelles tendances' in Salerno F. (ed) $L a$ nouvelle procedure devant la Cour europeenne des droits de l' homme qpres le Protocole no. 14: actes du colloque tenu a Ferrara les 29 et 30 avril 2005, (Bruylant, 2007).

Carbone S.M. and Schiano di Pepe L., 'States, Fundamental Rights and Duties' (2009) MPEPIL.

Cardwell P.J. (ed), EU External Relations Law and Policy in the Post-Lisbon Era (The Hague: T.M.C. Asser Press, 2012).

Cassese A., (ed) Leading by Example: A Human Rights Agenda for the European Union of the Year 2000 (European University Institute, 1998).

Corthaut T., Case CFI May 3, 2002, Jégo-Quéré v. Commission T-177/01 and C-50/00 P ECJ July 25, 2002, Unión de Pequeños Agricultores v Council (2002) Columbia Journal of European Law 141.

Christiansen T. and Dobbels M., 'Non-legislative Rule Making after the Lisbon Treaty: Implementing the New System of Comitology and Delegated Acts’ (2013) ELJ 42.

Clapham A., 'A Human Rights Policy for the European Community' (1990) Yearbook of European Law 309.

Clough M., 'Potential legal challenges to EU sanctions' (2013) 2 ITLR 27-37.

Condorelli L., 'L'imputation à l'état d'un fait internationalement illicite: solutions classiques et nouvelles tendances', (1984/VI) 189 Recueil des Cours 19. 
Craig P., The Lisbon Treaty: Law, Politics and Treaty Reform (OUP, 2010).

- - EU Administrative Law (2 ${ }^{\text {nd }}$ edn, OUP 2012).

_ - 'EU Accession to the ECHR: Competence, Procedure and Substance' (2013) 36 Fordham International Law Journal 1115.

- - 'The Financial Crisis, the EU Institutional Order and Constitutional Responsibility' in Fabbrini F., Hirsch Ballin E. and Somsen H., (eds), What Form of Government for the European Union and the Eurozone? (Hart, 2015).

— - and de Búrca G. EU Law Texts Cases and Materials (6 ${ }^{\text {th }}$ edn, OUP, 2015).

Creus A., 'Commentaire des decisions du Tribunal dans les affaires T-18/10-Inuit et T-262/10Microban' (2011) 3 Cahiers de droit européen 659.

d'Aspremont J., 'The Articles on the Responsibility of International Organisations: Magnifying the Fissures in the Law of International Responsibility', (2012) 9 International Organisations Law Review 15.

Dani M., 'Remedying European legal pluralism: the FIAMM and Fedon litigation and the judicial protection of international trade bystanders (Case Comment)' (2010) 21(2) EJIL 303.

Dannenbaum, T., 'Translating the Standard of Effective Control into a System of Effective Accountability: How Liability Should Be Apportioned for Violations of Human Rights by Member State Troop Contingents Serving as United Nations Peacekeepers', (2010) 51 Harv ILJ 113.

de Búrca G., 'The European Court of Justice and the International Legal Order After Kadi', (2009) 51(1) Harv ILJ 1. 
_ _ 'The Road not taken: The European Union as Global Human Rights Actor' (2011) 105 AJIL 649.

De Salvia M., 'La satisfaction équitable au titre des mesures individuelles et la pratique des organes de la Convention européenne des droits de l'homme : qu'en est - il du principe de sécurité juridique?' in Hartig H (ed) Trente ans de droit européen des droits de l'homme: études à la meoire de Wolfgang Strasser (Bruylant, 2007).

_ _ 'Le principe de l'octroi subsidiaire des dommages-intérêts : d'une morale des droits de l'homme une orale simplement indemnitaire?' in Flauss J-F and Lambert E. Abdelgawad (eds) La pratique d'indemnisation par la Cour européenne des droits de l'homme (Bruylant, 2011).

de Witte B., 'European Union Law: How Autonomous is its Legal Order?' (2010) 65 Zeitschrift für Öffentliches Recht 141.

- - and Imamovic S., 'Opinion 2/13 on accession to the ECHR: defending the EU legal order against a foreign human rights court' (2015) ELR 695.

de Vries S., Bernitz U and Weatherill S (eds)., The Protection of Fundamental Rights in the EU after Lisbon (Hart, 2013).

Delmine P., "The end of impunity? The legal duties of "borrowed" EU institutions under the European stability mechanism framework (Case Comment)' (2017) 13(2) ECLR 369.

di Federico G., (ed) The EU Charter of Fundamental Rights. From declaration to Binding Document (Dordrecht, Springer Netherlands 2011).

Doli D. and Korenica F., 'The EU-engineered hybrid and international specialist court in Kosovo: how "special" is it?' (2016) 12(3) ECLR 474. 
Doli D. and Korenica F., 'How powerful are Eulex judges and prosecutors in Kosovo' (2010) Revista General de Derecho Penal 14.

Douglas Scott S., 'A Tale of Two Courts: Luxembourg, Strasbourg and the Growing Human Rights Acquis' (2006) 43 CMLRev 629.

_ _ 'The European Union and Human Rights after the Treaty of Lisbon' (2011) HRLR 1.

Driessen B., 'Delegated Legislation after the Treaty of Lisbon: An analysis of Article 290 TFEU' (2010) 35 ELR 837.

Dusterhaus D., 'Procedural primary and effective judicial protection: a trilogue,' (2016) 23(2) Maastricht Journal of European and Comparative Law 317.

Eeckhout P., 'Liability of Member States in damages and the Community system of remedies' in Beatson J. and Tridimas T., (eds.), New Directions in European Public Law (Hart, 1998).

— - 'Does Europe's Constitution Stop at the Water's Edge? Law and Policy in the EU's External Relations', (2005) Walter van Gerven Lectures, Leuven.

— - EU External Relations Law, (2 ${ }^{\text {nd }}$ edn, OUP, 2011).

Engberg K., 'Ten Years of EU Military Operations (2003) <http://www.iss.europa.eu/uploads/media/Brief 41 EU military operations.pdf>.

Engelhard E., van den Broek B., de Jong F., Keirse A., de Kezel E., 'Let's Think Twice before We Revise! 'Égalité' as the Foundation of Liability for Lawful Public Sector Acts', (2014) 8 Utrecht L Rev 55. 
Enrich Mas E., 'Right to Compensation under Article 50' in Mcdonald J., Matscher F. and Petzold H. (eds) The European System for the Protection of Human Rights, (Martinus Nijhoff 1993).

Fabre-Magnan M., Droit Des Obligations 2 - Responsabilité civile et quasi-contrats (PUF $2^{\mathrm{e}}$ édition, 2010)

Fichera M., 'The European Arrest Warrant and the Sovereign State: A Marriage of Convenience?' (2009) 15 ELJ 70.

Fitzmaurice Sir G., 'The Law and Procedure of the International Court of Justice: International Organisations and Tribunals' (1952) 29 BYIL 1.

Foster S., 'Case Comment Prisoners' rights - right to vote - European Court of Human Rights just satisfaction’ (2014) Coventry Law Journal 78.

Gaja G., 'Articles on the Responsibility of International Organisations' United Nations Audiovisual Library of International Law, (United Nations Audiovisual Library of International Law) <http://legal.un.org/avl/pdf/ha/ario/ario_e.pdf>.

Gatti M., 'Diplomats at the Bar: the European External Action Service before EU courts' (2014) 39(5) ELR 664.

Gattinara G., 'WTO in Luxembourg: Inconsistencies and Perspectives', (2008) Italian Y.B. Int'1 Law 117.

Gazzini T., 'The Relationship between International Legal Personality and the Autonomy of International Organisations' in Collins R. and White N.D. (eds)International organisations and the idea of autonomy (Abingdon, Routledge 2011) 
Gianelli A., 'Customary International Law in the European Union', in Cannizzaro, Palchetti and Wessel (eds.) International Law as Law of the European Union (Brill/Nijhoff 2011).

Goldston R.J., Hamilton R., 'Bosnia v Serbia: lessons from the encounter of the International Court of Justice with the International Criminal Tribunal for the Former Yugoslavia', (2008) 21(1) Leiden Journal of International Law 95.

Grabitz E., Hilf M. and Nettesheim M (eds) Das Recht der Europäischen Union. Band I (Munich, Beck, 2010).

Gragl P. 'Beyond Bosphorus: The European Court of Human Rights' Case law on the Responsibility of Member States of International Organisations under the European Convention on Human Rights' (2010) 10 HRLR 529.

Griebel J. and Plücken M., 'New developments regarding the rules of attribution? The International Court of Justice's decision in Bosnia v Serbia' (2008) 21(3) Leiden Journal of International Law 601.

Griller S., 'International Law, Human Rights and the European Community's Autonomous Legal Order: Notes on the European Court of Justice Decision in Kadi' (2008) 4 ECLR 528.

Griller S., 'The Court of Justice and the Common Foreign and Security Policy', in Rosas A., Levits E. and Bot Y. (eds), Court of Justice of the European Union - Cour de Justice de l'Union Européenne, The Court of Justice and the Construction of Europe: Analyses and Perspectives on Sixty Years of Case-Law - La Cour de Justice et la Construction Européenne: Analyses et Perspectives de Soixante Ans de Jurisprudence (The Hague TMC Asser Press, 2013), 675-692.

Grotius H., De Jure Belli ac Pacis, Libri Tre (1625). 
Groussot X., Lock T. and Pech L., 'EU Accession to the European Convention on Human Rights: a Legal Assessment of the Draft Accession Agreement of 14th October 2011' European Issues $\mathrm{n}^{\circ} 218$, 〈http://www.robert-schuman.eu/doc/questions_europe/qe-218-en.pdf>.

Gutman K., 'The Evolution of the Action for Damages against the European Union and its Position in the System of Effective Judicial Protection' (2011) 48 CMLRev 695.

Haggenmacher P., Grotius et la Doctrine de la Guerre Juste (Paris : Presses Universitaires de France).

Hallstein W., Remarks, Eur. Parl. Deb, (79) (French edition) 17 June 1965.

Hayner P.B., Unspeakable Truths: Confronting State Terror and Atrocity (Routledge, New York and London, 2001).

Hazelzet H., 'Common Security and Defence Policy: What Nexus between Human Rights and Security?', in Sari A., and Wessel R.A. (eds), Human Rights in EU Crisis Management Operations: A Duty to Respect and to Protect? (The Hague: CLEER Working Paper Series 2012/6).

Heinrich T., 'Les Rapports entre le Droit Interne et le Droit International' (1923-I) 1 RCADI 121.

Heliskoski J., 'Responsibility and Liability in CSDP Operations' in Blockmans S. and Koutrakos P. (eds), Research Handbook on CFSP/CSDP (Elgar Publishing 2016)

Hernandez G.I. 'International Court of Justice' in d'Aspremont J., Participants in the International Legal System - Multiple Perspectives on non-state actors in international law, (Routledge 2011). 
Heukels T., 'De nietcontractueleaansprakelijkheid van de Gemeenschap ex art. 215, lid 2 EEG: Dynamiek en continuiteit (1983-1991)’ (1992) SEW 151.

Heukels T. and McDonnell A., 'Limitation of the action for damages against the Community: Considerations and new developments' in Heukels T. and McDonnell A., The Action for Damages in Community Law (Kluwer 1997).

Hirsch M., The Responsibility of International Organisations toward Third Parties (Dordrecht/London: Nijhoff, 1995).

Higgot R. et al, (eds) Non -State Actors and Authority in the Global System (2000).

Hobbes T., Leviathan (1651).

Hoffmeister F., 'Litigating against the European Union and its Member States - who responds under the ILC's Draft Articles on international responsibility of international organisations?' (2010) 21(1) EJIL 723.

Horspool M. and Humphreys M. European Union Law (6 ${ }^{\text {th }}$ edn, OUP, 2010).

Ichim O., Just Satisfaction under the European Convention on Human Rights (CUP, 2015).

Iglesias Sanchez S., The Court and the Charter: The Impact of the Entry into Force of the Lisbon Treaty on the ECJ's Approach to Fundamental Rights' (2012) 49 CMLRev 1565.

Johansen S.O., 'The Reinterpretation of TFEU Article 344 in Opinion 2/13 and Its Potential Consequences [comments]' (2015) 16 German LJ 169.

_ _ Accountability mechanisms for human rights violations by CSDP missions: available and sufficient?’' (2017) 66(1) ICLQ 181. 
Jacobs, White and Ovey C., The European Convention on Human Rights (7th edn, OUP, 2017).

Jacqué J.P., 'The Accession of the European Union to the European Convention on Human Rights and Fundamental Freedoms' (2011) 48 CMLRev 995.

Jaeger M., 'L'accès des personnes physiques ou morales à la justice: les premières interprétations par le Tribunal des nouvelles dispositions de l'Article 263, quatrième alinéa, TFUE' in Weitzel L. (ed) L'Europe des droits fondamentaux : mélanges en hommage à Albert Weitzel (Zutphen Paris Legal Publishers, 2013).

Jones $\mathrm{J}$ 'Standing space only in the CJEU: comment on Inuit Tapiriit Kanatami v European Parliament and Council.' (2014) 19(1) JR 65.

Jørgensen N., ‘A reappraisal of punitive damages in international law’ (1997) 68 BYBIL 247.

Juncos AE. And Reynolds C., 'The Political and Security Committee: Governing in the Shadow' (2007) 12 European Affairs Review 127.

Kaleda, S.L, 'Claims for damages in EU procurement and effective protection of individual rights' (2014) 39(2) ELR 193.

Kelsen H., 'Théorie Générale du Droit International Public' (1932-IV) 42 RCADI 121.

_ _ General Theory of Law and State (Cambridge (Mass.) Harvard University Press 1945).

Kiss A., 'Conciliation' in Mcdonald J, Matscher F and Petzold H (eds) The European System for the Protection of Human Rights (Dodtrecht: Martinus Nijhoff 1993).

Klabbers J., An Introduction to International Institutional Law ( ${ }^{\text {rd }}$ edn, CUP, 2015) 
Klein E., 'Das Verhaltins des Europäischen Gerichtshofs zum Gerichtshof für Menschenrechte' in Mertin D. and Papier J (eds) Handbuch der Grundrechte in Deutschland und Europa, Band VI/1 Europäische Grundrechte I (Heidelberg, CG Muller 2010) 1276.

Klein P., La responsabilité des organisations internationales dans les ordres juridiques internes et en droit des gens (Bruylant/Editions de l'Université de Bruxelles, 1998).

_ _ 'Responsabilité pour les faits commis dans le cadre d'opérations de paix et étendue du pouvoir de contrôle de la Cour européenne des droits de l'homme: quelques considérations critiques sur l'arrêt Behrami et Saramati', (2007) 53 Annuaire Français de Droit International 43.

Koch C., 'Locus Standi of Private Applicants under the EU Constitution: Preserving Gaps in the Protection of Individuals’ Right to an Effective Remedy’ (2005) 30 ELR 511.

Kollmar F and Hoffman JM, 'Fewer complaints, more satisfaction: Cyprus v Turkey (Case Comment)' (2014) 3(4) CJICL 1361.

Kondoch B., 'The Responsibility of Peacekeepers, Their Sending States, and International Organisations', in Gill T. and Fleck D., (eds.), The Handbook of the International Law of Military Operations (OUP, 2010).

Köngeter M., "Völkerrechtliche und innerstaatliche Probleme eines Beitritts der Europäischen Union zur EMRK” in J. Bast (ed), Die Europäische Verfassung - Verfassungen in Europa (Baden-Baden 2005).

Komárek J., 'European Constitutionalism and the European Arrest Warrant: in Search of the Limits of "Contrapunctual Principles"” (2007) 44 CMLRev 16.

Kornezov A., 'Locus standi of private parties in actions for annulment: has the gap been closed?' (2014) 73(1) CLJ 25. 
- _ 'Shaping the new architecture of the EU system of judicial remedies: comment on Inuit' (2014) 39(2) ELR 251.

Koutrakos P., 'Judicial review in the EU's common foreign and security policy' (2018) 67(1) ICLQ 1.

Kozma $\mathrm{J}$ et al, A World Court of Human Rights - Consolidated Statue and Commentary (Wien/Graz, Neuer Wissenschaftlicher Verlag, 2010).

Kress C., 'L'organe de facto en droit international public - réflexions sur l'imputation à l'état de l'acte d'un particulier à la lumière des développements récents', (2001) 105 Revue Générale de Droit International Public 93.

Kriebaum U., 'Restitution Claims for Massive Violations of Human Rights during the Nazi Regime' in Ulrich G, Krabbe Boserup L., (eds) Human Rights in Development Yearbook 2001 Reparations: Redressing Past Wrongs (Kluwer Law International, Nordic Human Rights Publications 2001).

Kristjánsdóttir M. V., 'Good Administration as a Fundamental Right' (2013) 9(1) Icelandic Review of Politics and Administration, 237.

Kronenberg V. and Dejmek P., 'Locus Standi of Individuals before Community Courts under Article 230(4) EC: Illusions and Disillusions after the Jégo-Quéré (T-177/01) and Unión de Pequeños Agricultores v Council (C-50/00 P) judgments' (2002) 4 European Legal Forum 257.

Kruger H.C.., 'Reflections Concerning Accession of the European Communities to the European Convention on Human rights' (2002) 21 Penn State International Law Review 89.

Kühling J., 'Grundrechte' in von Bogdandy A and Bast J., (eds) Europäisches Verfassungsrecht (Berlin Heidelberg, Springer 2009) 
Kuijper PJ, 'The European Courts and the Law of Treaties: the Continuing Story' in Cannizzaro E., (ed) The Law of Treaties beyond the Vienna Convention (OUP 2011).

Lacchi C., 'Multilevel judicial protection in the EU and preliminary references' (2016) 53(3) CMLRev 679.

Lambrecht S., 'The sting is in the tail: CJEU Opinion $2 / 13$ objects to draft agreement on accession of the EU to the European Convention on Human Rights' (2015) EHRLR 185.

Larsen K.M., 'Attribution of Conduct in Peace Operations: The 'Ultimate Authority and Control' Test' (2008) 19 EJIL 509.

Lauterpacht E., Aspects of the Administration of International Justice (Cambridge: Grotius Publications Limited, 1991).

Lauterpacht H., 'The Revision of the Statute of the International Court of Justice' (2002) 1 Law and Practice of International Courts and Tribunals 55.

Lawson R.A., 'Life after Bankovic: On the Extraterritorial Application of the European Convention of Human Rights' in Commans F and Kamming MT., (eds) Extraterritorial Application of Human Rights Treaties (Antwerp, Intersentia, 2004).

Lebeck C., 'The European Court of Human Rights on the Relation between ECHR and EC-Law: The Limits of Constitutionalisation of Public International Law' (2007) 62 Zeitschrift fur Öffentliches Recht 195.

Lenaerts K., 'The Rule of Law and the Coherence of the Judicial System of the European Union' (2007) 4 CMLRev 1625.

- - 'Droit International et Monisme de l'Ordre Juridique de l'Union' (2010) Revue de la Faculté de Droit de l'Université de Liège, 505. 
- — and Corthaut T 'Of Birds and Hedges: The Role of Primacy in Invoking Norms in EU law' (2006) 31 ELR 287.

- — and Gutiérrez-Fons J.A., 'The Place of the Charter in the EU Constitutional Edifice', in Peers S., Hervey T., Kenner J. and Ward A. (eds), The EU Charter of Fundamental Rights, (Hart Publishing, 2014) 1560.

_ - Maselis I., Gutman K., and Nowak J. T., EU Procedural Law (OUP 2014).

- - and van Nuffel P., Constitutional Law of the European Union (2nd edn Sweet and Maxwell 2005).

Lock T., 'EU Accession to the ECHR: Implications for Judicial Review in Strasbourg' (2010) 35 ELR 777.

- _ 'The ECJ and the ECtHR: the Future Relationship between the Two European Courts' (2009) 8 The Law and Practice of International Courts and Tribunals 375.

- - 'The future of the European Union's accession to the European Convention on Human Rights after Opinion 2/13: is it still possible and is it still desirable?' (2015) 11(2) ECLR 239.

_ _ 'The influence of EU law on Strasbourg doctrines' (2016) 41(6) CMLRev 804.

- - 'Walking on a Tightrope: the Draft Accession Agreement and the Autonomy of the EU Legal Order', (2011) 48 CMLRev 1025.

Locke J., Two Treatises of Government (1689). 
Loucaides, L. 'Reparation for violations of human rights under the European Convention and restitutio in integrum' (2008) 2 EHRLR 182.

Marmo M., 'The Execution of Judgments of the European Court of Human Rights - A political Battle' (2008) 15 Maastricht Journal of European and Comparative Law 235.

Mayer F.C., 'Art 19 EUV' in Grabitz E., Hilf M. and Nettesheim M (eds) Das Recht der Europäischen Union. Band I (Munich Beck 2010).

McCorquodale R., International Law beyond the State: Essays on Sovereignty, Non-State Actors and Human Rights (Cameron May 2011).

Mead P., 'The relationship between an action for damages and an action for annulment: The return of Plaumann', in Heukels T. and McDonnell A. (Eds.), The Action for Damages in Community Law (Kluwer 1997).

Milanović M. and Papić T., 'As Bad as It Gets: The European Court of Human Rights Behrami and Saramati Decision and General International Law', (2009) 58 ICLQ 267.

Missiroli A., 'The New EU Foreign Policy System after Lisbon: A work in Progress' (2010) 15 European Foreign Affairs Review 427.

Mitsilegas V., 'The Constitutional Implications of Mutual Recognition in Criminal Matters in the European Union' (2006) 43 CMLRev 1277.

Morano - Foadi S., 'Fundamental Rights in Europe: "Constitutional" Dialogue between the Court of Justice of the EU and the European Court of Human Rights' (2013) 5(1) Onati Journal of Emergent Socio-Legal Studies 64.

— - and Vickers L. Fundamental Rights in the EU - A matter of two courts (Hart 2015). 
Mowbray A., 'The creativity of the European Court of Human Rights', (2005) 5 HRLR 57.

Naert F., International Law Aspects of the EU's Security and Defence Policy (Intersentia 2010).

_ _ 'The International Responsibility of the Union in the context of its CSDP Operations' in Evans M., and Koutrakos P., (eds), The International Responsibility of the European Union (Hart Publishing 2013).

Neff S., 'A Short history of international Law' (ed) Evans M.D., International Law (OUP 2010).

Nielsen P., 'Human Dignity, International Protection’ MPEPIL (October 2012).

Nickel K and Reidy D, "Chapter 2 - Philosophy” in Moeckli D, Sivakumaran S., and Shah S. International Human Rights Law (OUP, 2010).

Nowak M., 'The Right to Reparation of Victims of Gross Human Rights Violations' in Ulrich G, Krabbe Boserup L., (eds) Human Rights in Development Yearbook 2001 - Reparations: Redressing Past Wrongs (Kluwer Law International, Nordic Human Rights Publications 2001).

_ _ 'Eight Reasons why we need a World Court of Human Rights' in Grimheden J et al (eds) International Human Rights Monitoring Mechanisms: Essays in Honour of Jacob Th Moller, $\left(2^{\text {nd }}\right.$ edn Leiden/Boston, Martinus Nijhoff Publishers 2009)

_ _ 'It's Time for a World Court of Human Rights' in Bassiouni MC and Schabas WA (eds) New Challenges to the UN Human Rights Machinery - What future for the UN Treaty Body System and the Human Rights Council Procedures? (Cambridge/Antwerp/Portland, Intersentia 2011).

- - et al, (eds) The Role of the EU in UN Human Rights Reform (Wien/Graz, Neuer Wissenschaftlicher Verlag, 2013). 
— — and Januzewski K.M. 'Non-State Actors and Human Rights' in Noorthmann M., Ryngaert C., Reinisch A., (eds). Non -state actors in international law (Hart, 2015).

O’Brien C., 'Equality’s False Summits: New Varieties of Disability Discrimination, 'Excessive' Equal Treatment and Economically Constricted Horizons' (2011) ELR 26.

O' Leary S., 'Courts, charters and conventions: making sense of fundamental rights in the EU' (2016) 56 IJ 4.

Oliveira A. and King S-J., 'A good chess opening: Luxembourg's first Roma case consolidates its role as a fundamental rights court (Case Comment)' (2016) 41(6) ELR 865.

Papastavridis, E., 'EUNAVFOR Operation Atlanta off Somalia: the EU in unchartered legal waters?' (2015) 64(3) ICLQ 533.

Peers S., Costa M., 'Judicial Review of EU acts after the Treaty of Lisbon' (2012) 8(1) ECLR 82.

Peers S, Hervey T., Kenner J. and Ward A. (eds), The EU Charter of Fundamental Rights, A Commentary (Hart Publishing 2014).

Pellet A., "L’imputabilité d'éventuels actes illicites. Responsabilité de l'OTAN ou des Etats membres", in Tomuschat C., (ed.), Kosovo and the International Community: A Legal Assessment (The Hague: Kluwer Law International, 2002).

Pérez de Nanclares M., 'Artículo 53', in Mangas Martín A. (ed.), Carta de los Derechos Fundamentales de la Unión Europea-Comentario artículo por artículo (Fundación BBVA 2008).

Pérez González M., “Les organisations internationales et le droit de la responsabilité”, (1988) 92 Revue Générale de Droit International Public 63. 
Pescatore P., 'The Doctrine of 'Direct Effect': An infant disease of Community law' (1983) 8 ELR 155.

Poli S., 'The Common Foreign Security policy after Rosneft: still imperfect but gradually subject to the rule of law' C.M.L. Rev. 2017, 54(6), 1799-1834.

Portmann R., Legal Personality in International Law (Cambridge: Cambridge University Press 2010).

Rasmussen M., 'Revolutionizing European Law: A History of the Van Gend en Loos judgment' (2014) 12 ICON 136.

Rauchegger C. and Lambrecht S., 'European Union: The EU's Attitude to the ECHR' in P. Popelier et al (eds.), Criticism of the European Court of Human Rights: Shifting the Convention System: Counter-Dynamics at the National and EU Level (Cambridge: Intersentia, 2016).

Reinisch A., International Organisations before National Courts (CUP 2000).

_ _ 'The Changing International Legal Framework' in cf. Alston Non-state actors and human rights (OUP 2005).

Ritfner W., 'Basic Elements of German Law on State Liability in John Belland Anthony W Bradley (eds), Governmental Liability: A Comparative Study (UKNCCL, 1991) 252

Ritter J-P., 'La protection diplomatique à l'égard d'une organisation internationale', (1962) 8 Annuaire Français de Droit International, 427.

Ress G., 'The Effect of Decisions and Judgments of the European Court of Human Rights in the Domestic Legal Order' (2008) 40 Tex Intl LJ, 359-384.

Reuter P., Institutions Internationales (Paris : Presses Universitaires 1955). 
Robin - Olivier S., 'The Evolution of Direct Effect in the EU: Stocktaking, Problems, Projections' (2014) 12 ICON 165.

Rosas A., 'Is the EU a Human Rights Organisation?', CLEER Working Paper 2011/1.

Rose C., 'The Limitations of a Human Rights Approach to Corruption' (2016) 65(2) ICLQ 404.

Rotberg R.I. and Thompson D. (eds) Truth v. Justice. The morality of Truth Commissions (OUP 2000).

Ryssdal R., Lecture Given at Masaryk University, March 1996.

Safjan M. and Dusterhaus D., 'A union of effective judicial protection: Addressing a multi-level challenge through the lens of Article 47 CFREU' (2014) 33 YEL 3.

Salmon J.A.A., 'Les accords Spaak-U Thant du 20 février 1965' (1965) 11 Annuaire Français du Droit International 468.

Sari A., 'Jurisdiction and International Responsibility in Peace Support Operations: The Behrami and Saramati Cases', (2008) 8 HRLR 151.

_ _ 'Status of Forces and Status of Mission Agreements under the ESDP: The EU's Evolving Practice' (2008) 19 EJIL 67-100.

Sari A., and Wessel R.A. (eds), Human Rights in EU Crisis Management Operations: A Duty to Respect and to Protect? (The Hague: CLEER Working Paper Series 2012/6).

Sassòli M. and Olson G., 'International Decision: Prosecutor v. Tadić', (2000) 94 AJIL 571 
Schilling T., 'The Autonomy of the Community Legal Order: An Analysis of Possible Foundations' (1996) 37 Harvard International Law Journal 389.

Schermers H.G. and Blokker N.M., International Institutional Law: Unity in Diversity (Martinus Nijhoff Publishers 2011).

Schuman R., 'Declaration of 9 May 1950', in European Parliament, Selection of Texts concerning Institutional Matters of the Community for 1950-1982, (Luxembourg, Office for Official Publications of the European Communities, 1982) 47.

Schwarze J., 'The Legal Protection of the Individual against Regulations in European Union Law' (2004) 10(2) Kluwer Law International 285.

Schwarzenberger G., International Law: International Law As Applied by International Courts and Tribunals ( $3^{\text {rd }}$ edn Stevens and Sons 1957).

Sereni A.P. Diritto Internazionale (II/2) (Milan Guiffre 1960).

Seyersted F., 'United Nations Forces: Some Legal Problems’ (1961) 37 BYIL 351.

Shelton D., 'International Law and "Relative Normativity"' in (ed) Evans M.D., International Law (OUP 2010).

Shaw M., International Law (4 ${ }^{\text {th }}$ edn 1997).

Shany Y., The Competing Jurisdictions of International Courts and Tribunals (OUP 2003).

Shraga D., 'UN Peacekeeping Operations: Applicability of International Humanitarian Law and Responsibility for Operations - Related Damage'(2000) 94 AJIL 406. 
Simon D., 'Des influences réciproques entre CJCE et CEDH: Je t’aime, moi non plus!' (2001) 96 Pouvoirs 31 .

Spernbauer M., EU Peacebuilding in Kosovo and Afghanistan: Legality and Accountability (Brill 2014).

Stanley P. 'The fine distinction between regulatory acts and acts that regulate' (2013) 157(40) S.J. 27.

Steele J., 'Damages in tort and under the Human Rights Act: remedial or functional separation?' (2008) CLJ 606.

Teitel R. Transitional Justice (Oxford and New York OUP 2000).

Thies A., 'The impact of general principles of EC law on its liability regime towards retaliation victims after FIAMM' (2009) ELR 889

Thirlway H., 'The Sources of International Law' in (ed) Evans M.D., International Law (OUP 2010).

Thomas S., 'Community Liability for Lawful Conduct: An Aborted Child? Some Comments on the FIAMM Judgment of the ECJ' (13 November2009). Available at SSRN.

Tomuschat C., 'Note on Kadi' (2005) CMLRev 537

Tomuschat C., 'What is 'Breach' of the European Convention on Human Rights?' in The Dynamics of the Protection of Human Rights in Europe: Essays in Honour of Henry G. Schermers, (Rick Lawson \& Matthijs de Blois ed, 2004). 
Toth A.G., 'The Concepts of Damage and Causality as Elements of Non-Contractual Liability', in Heukels T. and Mc Donnell A (eds) The Action for Damages in Community Law (Kluwer 1997)

Trhipanyane T, 'Current Claims, Regional Experiences, Pressing Problems' in Ulrich G, Krabbe Boserup L., (eds) Human Rights in Development Yearbook 2001 - Reparations: Redressing Past Wrongs (Kluwer Law International, Nordic Human Rights Publications 2001).

Tsagourias N., 'The Responsibility of International Organisations for Military Missions', in Odello M. and Ryszard P. (eds.) International Military Missions and International Law (Brill 2011).

Ulrich G., 'The Moral Case for Reparations' in Ulrich G, Krabbe Boserup L., (eds) Human Rights in Development Yearbook 2001 - Reparations: Redressing Past Wrongs (Kluwer Law International, Nordic Human Rights Publications 2001).

van Boven T., 'The right to restitution, compensation and rehabilitation for victims of gross violations of human rights and fundamental freedoms' in Alfredsson G., The living law of nations (Khel am Rhein, Engel, 1996).

van Dam C., European Tort Law (OUP 2013).

_ _ 'The Netherlands liable towards family of Srebrenica victims', (2011) 15(27) Insight American Society of International Law <https://www.asil.org/insights/volume/15/issue/27/netherlands-found-liable-srebrenica-deathss >

- —Who's Afraid of Diversity? Cultural Diversity, European Co-Operation, and European Tort Law' (2009) 20 KLJ 281.

van Gerven W., 'De niet-contractuele aansprakelijkbeid van de Gemeenschap wegens normatievehandelingen', (1976) SEW 2. 
— - 'Non-contractual Liability of Member States, Community Institutions and Individuals for Breaches of Community Law with a View to a Common Law for Europe', (1994) Maastricht Journal of European and Comparative Law 1.

van Malleghem PA and Baeten N. 'Before the law stands a gatekeeper - or what is a regulatory act in art.263(4) TFEU? Inuit Tapiriit Kanatami v European Parliament (C-583/11 P)' (2014) 51(4) CMLRev. 1187.

van Vooren B., 'A Legal Institutional Perspective on the European External Action Service' (2011) 48 CMLRev 475-502.

— - and Wessel R.A, EU External Relations Law, Text, Cases and Materials (CUP 2014).

Vattel G., Le Droit des Gens, Préliminaires.

Vegleris P., 'Modes de redressement des violations de la Convention européenne des droits de l'homme: esquisse d'une classification' in Mélanges offerts a Polys Modinos: problèmes des droits de l'homme et de l' unification européenne (Paris: Pedone 1968).

Vogel J and Spencer J., 'Proportionality and the European Arrest Warrant' (2010) Crim LR 474.

von Bogdandy A., 'The European Union as Human Rights Organisation: Human Rights and the Core of the European Union' (2000) 37 CLMRev 1307.

von Pufendorf S., De Jure Naturae et Gentium Libri Octo (1688).

von Verdross, 'Forbidden Treaties in International Law' (1937) 31 AJIL 571.

Waddington L., 'Future Prospects for EU Equality Law: Lessons to be Learnt from the Proposed Equal Treartment Directive' (2011) 36 ELR 163. 
Weiler JHH 'Van Gen den Loos: The Individual as Subject and Object and the Dilemma of European Legitimacy’ (2014) 12 ICON 94.

Weiss W., 'Human rights in the EU: rethinking the role of the European Convention on Human Rights after Lisbon' (2011) 7(1) ECLR 64.

— _ 'Is the CJEU Turning into a Human Rights Court?' in Morano Foadi S and Vickers L Fundamental Rights in the EU - A matter of Two Courts (Hart, 2015).

_ _ 'The EU Human Rights Regime Post Lisbon: Turning the CJEU into a Human Rights Court?' in Morano-Foadi S. and Vickers L., Fundamental Rights in the EU - A Matter of two Courts (Hart, 2015).

Weissbrodt D. and Kruger M., 'Human Rights Responsibilities of Businesses as Non-State Actors' (2005) 13 Non-State Actors and Human Rights 315.

Wessel R.A. 'IGOs as Non-State Actors' in Noorthmann M., Ryngaert C., Reinisch A., (eds). Non -state actors in international law (Hart 2015).

_ _ 'Revisiting the international legal status of the EU' (2000) 5 European Foreign Affairs Review 507.

Wetzel J. (ed) The EU as a 'Global Player' in Human Rights? (New York, Routledge, 2011)

Wittich S., 'Awe of the gods and fear of the priests: punitive damages in the law of State responsibility', (1998) 3(1) Austrian Review of International and European Law 101.

White S., 'The Accession of the European Union to the European Convention of Human Rights' (2011) 86 Amicus Curiae 7. 
Williams A., The Irony of Human Rights in the European Union (OUP 2004).

Wolff C., Jus Gentium, Book VII, Ch VI.

Zwanenburg M., Accountability of Peace Support Operations (Brill/Nijhoff 2005).

\section{Reports, Official Documents and Publications}

Commission of the European Communities 'Memorandum on the Accession of the European Communities to the Convention for the Protection of Human Rights and Fundamental Freedoms' Bullentin Supplement.

Common Security and Defence Policy of the European Union: Missions and Operations Annual Report 2016, EEAS Publication 2016, http://eupolcopps.eu/sites/default/files/newsletters/e_CSDP_Annual\%20Report.pdf

Council of Europe Manual of the Council of Europe. Its Structure, Functions and Achievements (Stevens, London 1970).

Council of Europe Parliamentary Assembly Resolution $1610 \quad$ (2008) <http://assembly.coe.int/Main.asp?link=/Documents/AdoptedText/ta08/ERES1610.htm\#1〉

Council of Europe Parliamentary Assembly Recommendation 1834 (2008) <http://assembly.coe.int/Main.asp?link=/Documents/AdoptedText/ta08/EREC1834.htm> Accessed 7 August 2012.

EULEX - Towards an integrated exit strategy - Strengthening the rule of law through EUintegration', A Policy Report by GLPS and DPC No. 05 (April 2014).

European Commission, Communication on Enhancing security in a world of mobility: improved information exchange in the fight against terrorism and stronger external borders, 12307/16, 19 
http://europeanmemoranda.cabinetoffice.gov.uk/files/2016/09/st12307.en16_.pdf

European Court of Human Rights Annual Report of 2001, Address given by Gil Carlos Rodriguez Iglesias, President of the Court of Justice of the European Communities, on the occasion of the Opening of the Judicial Year (Strasbourg, 31 January 2002) <http://www.cvce.eu/viewer/-/content/c201f6b4-21c4-408b-9a72-3b083048d5ec/en>.

European Regional Office of the United Nations' High Commissioner for Human Rights Report, 'The European Union and International Human Rights Law', <http://www.europe.ohchr.org/Documents/Publications/EU_and_International_Law.pdf >

Exchange of letters between the United Nations High Commissioner for Refugees and the European Commission, of 15 February 2005, available at: http://www.unhcr.org/refworld/docid/42135cba4.html.

Explanations Relating to the Charter of Fundamental Rights [2007] OJ C303/28

Final Report, Accountability of International Organisations, International Law Association, Berlin Conference (2004).

Final report of the Special Rapporteur Bassiouni UN-Doc E/CN 4/2000/62.

French Senate, “Communication de Robert Badinter sur le mandat de négociation” (E 5248) (25 May 2010), www.senat.fr/europe/r25052010.html\#tocl .

General Comment No. 31, 26 May 2004, Human Rights Committee, CCPR/C/21/Rev.1/Add13. EULEX - Towards an integrated exit strategy - Strengthening the rule of law through EUintegration', A Policy Report by GLPS and DPC No. 05 (April 2014) 
Hearing of the European Parliament's Constitutional Affairs committee, Address by Viviane Reding, The EU's Accession to the European Convention on Human Rights: Towards a Stronger and more coherent protection of Human Rights in Europe (18 March 2010) <http://ec.europa.eu/commission_2010-2014/reding/pdf/speeches/speech_20100318_1_en.pdf>

High-Level Task Force on the Implementation of the Right to Development, 'Technical Mission Report: Cotonou Partnership Agreement between the European Union (EU) and African, Caribbean and Pacific (ACP) countries', UN Doc. A/HRC/8/ WG.2/TF/CRP.4, 28 December 2004.

Human Rights Review Panel for EULEX, Annual Report for 2015 http://hrrp.eu/docs/HRRP\%20Annual\%20Report\%202015.pdf

Independent Inquiry into the actions of the United Nations during the 1994 genocide in Rwanda, S/1999/1257, Enclosure.

Letter of the Secretary General of the United Nations to the Soviet Union, dated 6 August 1965 the Secretary General of the United Nations stated to the Soviet Union United Nations, Juridical Yearbook 1965 (Sales No. 67.V.3).

Note of the Director General of the International Atomic Energy Agency, where these three forms of reparation were considered to be applicable to the case of an international organisation GOV/COM.22/27, dated 24 June 1970

Notification on Permanent Structured Cooperation of 13 November 2017 to the Council and the High Representative of the Union for Foreign Affairs and Security Policy < http://www.consilium.europa.eu/media/31511/171113-pesco-notification.pdf>

Observance by United Nations forces of international humanitarian law, United Nations, Secretary - General's Bulletin ST/SGB/1999/13, 6 August 1999. 
Presidency, Council of the European Union, 'Accession of the EU to the Convention - State of play'

<http://register.consilium.europa.eu/pdf/en/11/st18/st18117.en11.pdf〉 .

Recommendation 1834 (2008) of the Parliamentary Assembly of the Council of Europe <http://assembly.coe.int/Main.asp?link=/Documents/AdoptedText/ta08/EREC1834.htm>

Report to the Committee of Ministers of the Council of Europe on the elaboration of legal instrument for the accession of the European Union to the European Convention on Human Rights, CDDH (2011)009 (Strasbourg, 14 October 2011), "Draft Explanatory report to the Agreement on the Accession of the European Union to the Convention for the Protection of Human Rights and Fundamental Freedoms. <http://www.statewatch.org/news/2011/oct/eu_cddh_Convention_report.pdf.>

Resolution 1610 (2008) of the Parliamentary Assembly of the Council of Europe <http://assembly.coe.int/Main.asp?link=/Documents/AdoptedText/ta08/ERES1610.htm\#1>

Resolution 1979 (2014) Parliamentary Assembly of the Council of Europe

Resolution 1226/2000, Execution of judgments of the European Court of Human Rights, Parliamentary Assembly ( $30^{\text {th }}$ Sitting), Council of Europe.

Provisional Draft, Information Note from the Commission on progress in implementing the UN Convention on the Rights of Persons with Disabilities. Available at $<$ http://ec.europa.eu/social/main.jsp?catId=431\&langId=en>.

Swiss Confederation, Federal Department of Foreign Affairs DFA/ Geneva Academy of International Humanitarian Law and Human Rights, Protecting Dignity: An Agenda for Human Rights. 


\title{
TABLE OF CASES
}

\section{EUROPEAN UNION}

\begin{abstract}
A. Court of Justice of the European Union / European Court of Justice
\end{abstract}
i. Judgments

A. Brunsteinder and Autohaus Hilgert Joined Cases C-276/05 and C-377/05 [2006] ECR I -

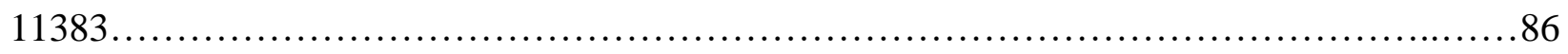

Afton Chemical Case C-343/09 [2010] ECR I-7023 ..................................... 81 Air Transport Association of America and Others, Case C-366/10,

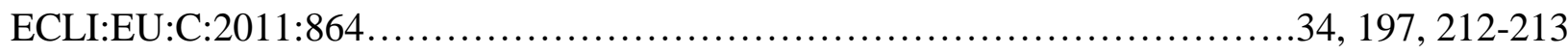
Aktien -Zuckerfabrik Schöppenstedt v. Council Case 5/71 [1971] ECR 975.... 97, 102, 110, 170 Al-Jubail Fertilizer v. Council Case C-49/88 [1991] ECR I-3187..............................51 Albini v. Council Case 33/80 [1981] ECR 2141 .........................................92 Alkagaren v. Hans Akerberg Fransson Case C-617/10 EU:C:2013:105......................82 Antillean Rice Mills NV v. Commission Case C-390/95 P [1999] ECR I-769................97, 124 Antonissen v. Council and Commission Case C-393/96 P (R) [1997] ECR I-441_..............105 Arcelor Atlantique et Lorraine and Others Case C-127/07 [2008] ECR I-9895............122, 129 Association Belge des Consommateurs Test-Achats ASBL and Others v Conseil des ministres Case C-236/09 [2011] ECR I-00773 ................................................... 85

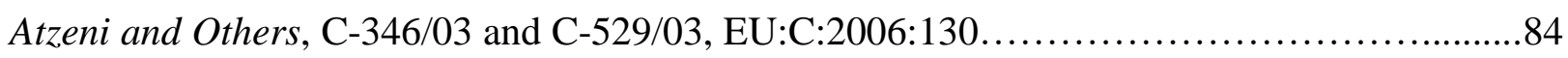

Austria v Council [2001] Case C-445/00 R ECR I-1461 ....................................104 Banco Privado Português and Massa Insolvente do Banco Privado

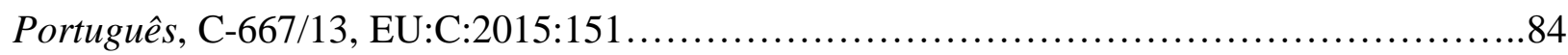
Bayerische HNL Vermehrungbetriebe GmbH \& Co KG v. Council and Commission Cases 83,94/76, 4, 15 and 40/77 [1978] ECR 1209..........................................111

Bertelsmann and Sony Corporation of America v. Impala Case C-413/06 P [2008]..............68 Brasserie du Pêcheur SA v. Germany, $R$ v. Secretary of State for Transport ex p Factortame Ltd Cases C-46 and 48/93 [1996] ECR I-1029.................................................111 
British Aggregates Association v. Commission Case 487/06 P [2008] ECR I-10515. 61

British American Tobacco (Investments) and Imperial Tobacco Case C-491/01 [2002] ECR I 11453

Calpak SpA and Società Emiliana Lavorazione Frutta SpA v Commission of the European Communities Joined Cases C-789/79 and C-790/69 [1980] ECR -01949. .61

CHEZ Razpredelenie Bulgaria AD v Komisia za zashtita ot diskriminatsia Case C-83/14 [2016]

1 CMLR 14. .131

ClientEarth v. Commission Case C-612/13 P ECLI:EU:C:2015:486. .70

Codorniu v. Council Case C-309/89 [1994] ECR I-1853. 8,61

Commission v. Council Case 22/70 [1971] ECR 263.....................................50

Commission v. Fresh Marine A/S Case C-472/00 P [2003] ECR I-7541.......................167

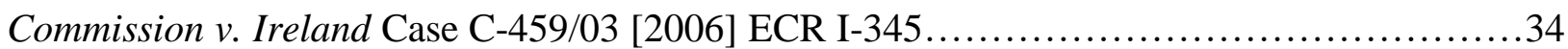

Commission v. Systran and Systran Luxembourg Case C-103/11 P

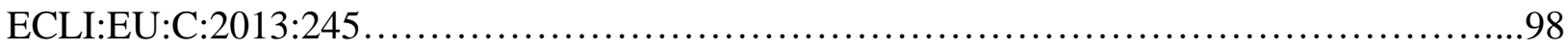

Commission v. Systraval and Brink's France Case C-367/95 P [1998] I-1719..................54

Comptoir National Technique Agricole (CNTA) SA v. Commission Case 74/74 [1975] ECR 533. 100

Cooperative Agricola Zootecnica S Antonio v. Amministrazione delle Finanze dello Stato Cases

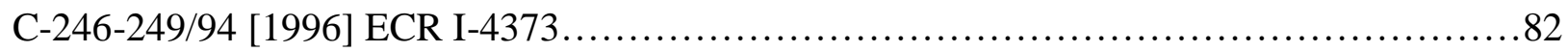

Council of the European Union v. Bank Mellat Case C-176/13 P ECLI:EU:C:2016:96.........72 Council of the European Union v Front populaire pour la libération de la saguia-el-hamra et du rio de oro (Front Polisario) Case C-104/16 P ECLI:EU:C:2016:973_................57, 63, 64 Council of the European Union v Manufacturing Support \& Procurement Kala Naft Co., Tehran

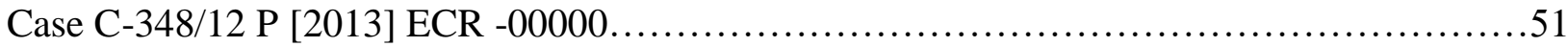

Criminal Proceedings against Maria Pupino Case C-105/03 [2005] ECR I - 5285............28 Digital Rights Ireland Ltd v Minister for Communications, Marine and Natural Resources and Others and Kärntner Landesregierung and Others Joined Cases C-293/12 and C- 594/12 ECLI:EU:C:2014:238 .85

Dorsch Consult Ingenieurgesellschaft mbH v. Council and Commission Case C-237/98 P [2000] ECR I- 4564. 159 
Dumortier Frères SA v. Council Cases 64, 113/76, 167, 27, 28, and 45/79 [1979] ECR 3091 103,134

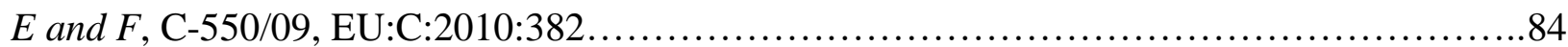

European Commission and Others v Yassin Abdullah Kadi Joined Cases C-584/10 P, C-593/10 P

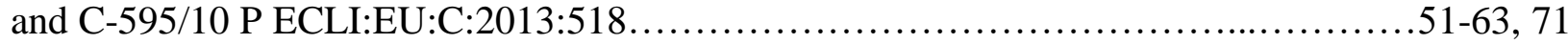

FIAMM and Others v. Council and Commission Joined Cases C 120/06 and C121/06 [2008] ECR I-06513..............................100, 102, 114, 115, 138, 140, 162, 161, 162, 277

Firma A Racke v. Hauptzollamt Mainz Case 98/78 [1979] ECR 69..........................57

Firma Foto - Frost v. Hauptzollamt Lubek -Ost Case C 314/85 [1987] ECR 4199............83

FNAB v Council Case C-345/00, [2001] ECR I-3811................................. 10, 61

France v. Commission Case C-327/91 [1994] ECR I-3641.................................87

France v. High Authority Case 1/54 [1954 to 1956] E.C.R. 1...............................63

Fux v. Commission [1969] ECR 145........................................103, 134

Gascogne Sack Deutschland GmbH v European Commission Case C-40/12 [2014] 4 CMLR 12 . 107,279

Gassmayr v. Bundesminister fur Wissenschaft und Forschung Case C-194/08

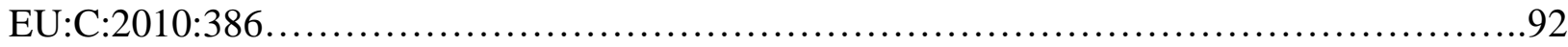

Gauff v. Commission Case 182/80 [1982] ECR 799...................................50, 53

Gerhardus Leussink and others v Commission of the European Communities, Cases 169/83 and 136/84 [1986] ECR 1986-02801.... 137,166

Germany v. Council Case C-122/95 [1989] ECR I-973.................................. 70

Gérard Buono and Others v European Commissionoined Cases C-12/13 P and C-13/13 P

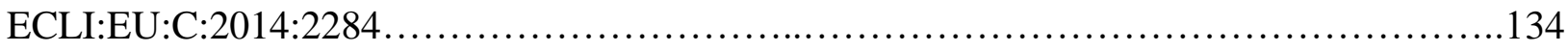

Groupe Gascogne SA v European Commission Case C-58/12 P [2014] 4 CMLR

14 . $107,141,167,279$

H Case C-455/14 P ECLI:EU:C:2016:212 .......................................90

Haegeman Case 181/73 [1974] ECR 449....................................33, 174, 197

Hanssens-Ensch v European Community Case C-377/09 [2011] 1 CMLR 13.................166

Hassan and Aydi v. Council and Commission Cases C-399 and 403/06 P [2009] ECR I-

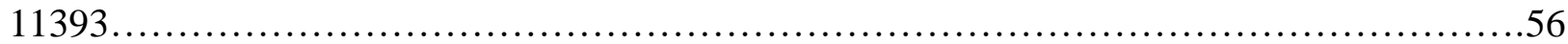

Hedley Lomas Case C-5/94 [1996] ECR I-2553......................................114 
Hoechst Joined Cases 46/87 \& 227/88 [1989] ECR 2859...............................28

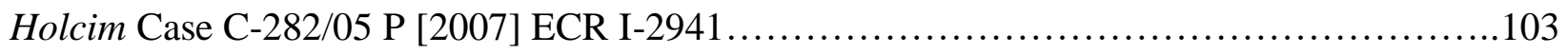

IBM v. Commission Case 60/81 [1981] ECR 2639.......................................53

Impresa Pizzarotti Case C-213/13 EU:C:2014:2067.............................................................86

International Association of Independent Tanker Owners (Intertanko) and others $v$ Secretary of State for Transport Case C-308/06 [2008] ECR I-4057...........................33-34, 197

International Fruit Company v Produktschap voor Groenten en Fruit Cases C- 21-24/72 [1972]

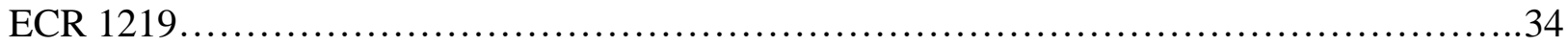

Internationale Handelsgesellschaft v Einfuhr - und Vorratsstelle für Getreide und Futtermittel Case 11/70 [1970] ECR 1125...........................................18, 25, 64

Inuit Tapiriit Kanatami and others $v$ European Parliament and Council of the European Union Case C-583/11 P [2014] 1 CMLR 54.....................................60, 63, 65

Inuit Tapiriit Kanatami v European Commission C-398/13 P EU:C:2015:535_..........84, 92

Ireks-Arkady v. Council and Commission Case 238/78 [1979] ECR 2955..............105, 137

Johannes Tomana v. Council Case C-330/15 P ECLI:EU:C:2016:96.......................73

Jose Maria Sison v. Council Case C-266/05 P [2007] ECR I-1233........................57

Kampffmeyer v. Commission and Council Cases 56-60/74 [1976] ECR 711.............105, 137

Konstantinos Mallis and Others v European Commission and European Central Bank (ECB) C109/15 P ECLI:EU:C:2016:702....................... 13, 69, 78, 108, 167, 184, 279, 286

Krohn Import-Export v Commission Case 175/84 [1986] ECR 753........................121

Kucukdeveci v. Swedex \& Co KG Case C-555/07 EU:C:2010:365.........................82

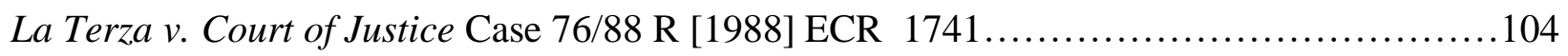

Laboratoires Pharmaceutiques Bergaderm SA and Goupil v. Commission Case C-352/98 P

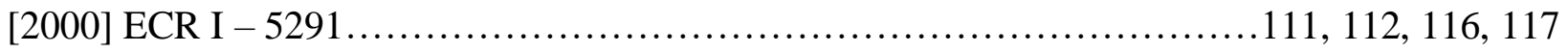

Ledra Advertising Ltd and Others v. European Commission and European Central Bank Joined Cases C-8/15 P to C-10/15 P ECLI:EU:C:2016:7....................12, 13, 27, 69, 108, $121,129,167,279,282$

Lemmerz-Werke v High Authority Joined Cases 53/63 and 54/63 [1963] ECR 23..............57

Ludwigshafener Walzmühle Erling and Others v Council and Commission Joined Cases 197/80 to 200/80, 243/80, 245/80 and 247/80 [1981] ECR 3211 ............................ 121

Mangold v. Rudiger Helm Case C-144/04 [2005] ECR I-9981..............................82 
Melki and Abdeli Joined Cases C-188/10 and C-189/10 [2010] ECR I - 5665. .86

Melloni v Ministerio Fiscal Case C-399/11 [2013] EU:C:2013:107.......26, 130, 239-240, 268

M.M. v. Minister for Justice, Equality and Law Reform, Ireland and Attorney General Case C -

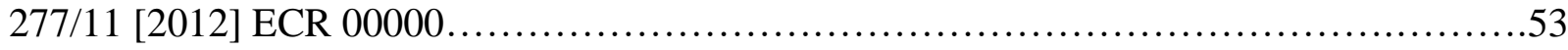

Mugraby Case C-581/11 P ECLI:EU:C:2012:466............................139, 174

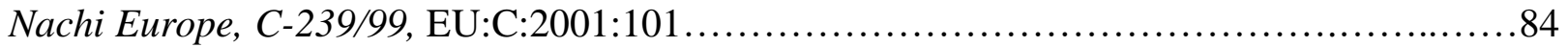

National Farmers' Union, C-241/01, EU:C:2002:604...............................84

National Front v. European Parliament Case C-486-01 P [2004] ECR I-6289................60

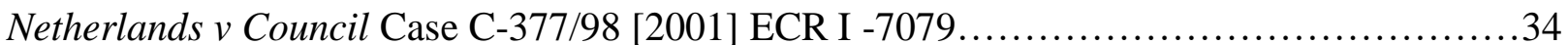

Nold v Commission Case 4/73, [1974] ECR 491............................18, 25, 56, 138

NV Algemene Transporten Expeditie Onderneming van Gend en Loos $v$. Nederlandse Administratie der Belastingen Case 26/62 [1963] ECR 1.........................37, 81, 82

Parliament v. Council (Al Qaeda) Case C-130/10 ECLI:EU:C:2012:472 .......................77

Phol Boskamp GmbH \& Co KG v. Gemeinsamer Bundesausschuss Case C-317/05 [2006] ECR I10611. .82

PJSC Rosneft Oil Company $v$ Her Majesty's Treasury and Others

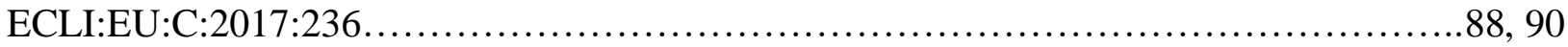

Plaumann \& Co v. Commission Case 25/62 [1963] ECR I-2343.................8, 60, 112, 113

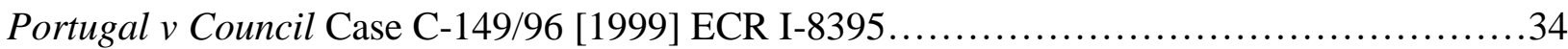

Qualitest v. Council Case C-644/11 P(R) (Order of the President of 14 June 2012)............104 $R$ v. Minister for Agriculture, Fisheries and Food, ex parte Fedesa Case C-331/88 [1990] ECR I4023

Racke GmbH v. Haptzollamt Mainz Case C-162/96 [1998] ECR I-3655. $57,211-212$

Razzouk and Beydoun v. Commission Cases 75 and 117/82 [1984] ECR 1509................56

Roquette v. Commission Case 26/74 ECR 1976. 141,149

Roquette Frères Case C-228/92 [1994] ECR I-4445...................................87

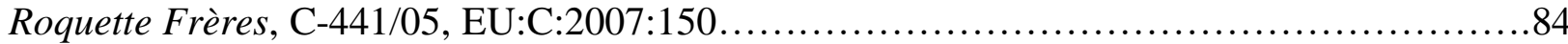

Rutili v Ministre de l'Intérieur Case 36/75 [1975] ECR 1219...........................18, 25

SA Biovilac NV Case 59/83[1984] ECR 4057......................................159

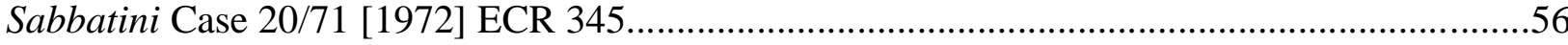


Safa Nicu Sepahan Co. $v$ Council of the European Union Case C-45/15 P

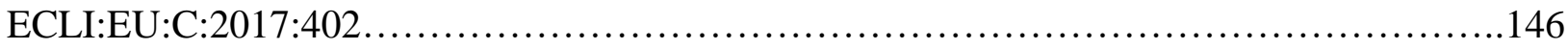

Salemink v Raad van Bestuur van het Uitvoeringsinstituut Werknemersverzekeringen Case C347/10 [2012] 2 CMLR 6.................................................... 76,286

Samba Diouf Case C-69/10 ECLI:EU:C:2011:524_.......................................

Selex Sistemi Integrati v. Commission C-481/07 P ECLI:EU:C:2009:191 .......135, 137, 155, 280

Sgarlata v Commission Case 40/64 [1965] E.C.R. 215, 227 ................................., 61

Simmenthal SpA v. Commission Case 92/78 [1979] ECR 777.................................86

Singer Case 44/65 [1965] E.C.R. 965 .................................................. 94

Société des Usines à Tubes de la Sarre v. High Authority Joined Cases 1/57 and 14/57 [1957]

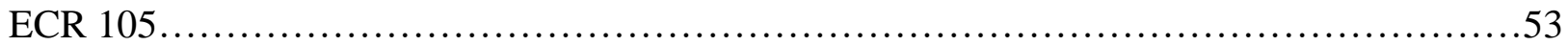

Société Louis Dreyfus \& Cie v. Commission Case C-386-96 [1998] ECR I-2309.................60

Société Regie Networks Case C- 333/07 [2007] ECR I-10807............................... 87

Solvay v. Commission Case C-109/10 P [2011] ECR 1-10329..................................68

Transocean Marine Paint Association v. Commission of the European Communities Case 17-74

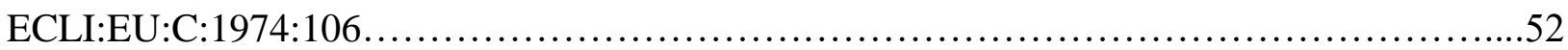

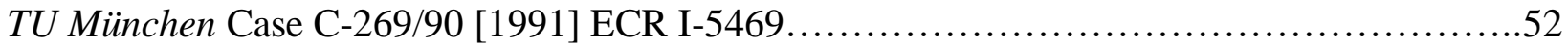

TWD Textilwerke Deggendorf GmbH v. Germany Case C-188/92 [1994] ECR I-833.............84

Union nationale des entraîneurs et cadres techniques professionnels du football (Unectef) $v$ Georges Heylens and others, Case 222/86 [1987] ECR -04097..............................52

United Kingdom of Great Britain and Northern Ireland v European Parliament and Council of the European Union (Re delegation of powers to ESMA) (Spain, France, Italy and European Commission, intervening) Case C-270/12 [2014] 2 CMLR 44...............................170

Union Malt v. Commission, Cases 44-51/77 [1978] ECR - 57..............................112

UPA v. Council Case C-50/00P [2002] ECR I-6677...........................8, 61, 66, 67, 80

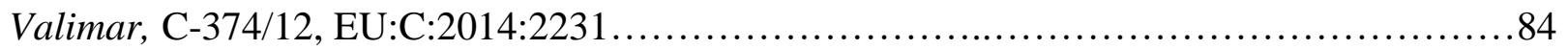

Walter Rau Lebensmittelwerke v. Bundesanstalt fur Landwirtschaftliche Martordnung Cases C-

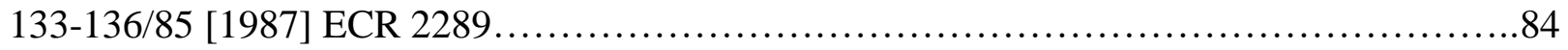

Walz v. Clickair SA Case C-63/09 ECLI:EU:C:2010:251_............................246

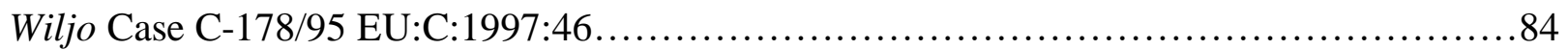


Yassin Abdullah Kadi and Al Bakaraat International Foundation v Council and Commission Cases C-402/05 and 415/05, P [2008] ECR I-6351.........................25, 26, 56, 71

Z v. A Government Department Case C-363/12 EU:C:2014:159.....................200,213

Zaoui v. Commission Case C-288/03 P ECLI:EU:C:2004:633......................139, 174

ZZ v Secretary of State for the Home Department Case C-300/11 ECLI:EU:C:2013:363.......52

ii. Opinions

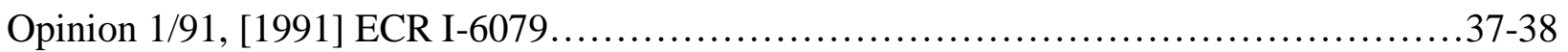

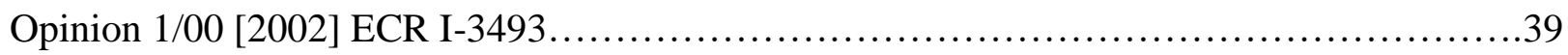

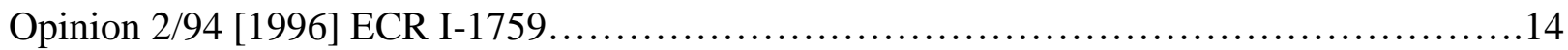

Opinion 2/13 EU:C:2014:2454_....................15, 32, 90, 175, 202, 243, 267 284-288

B. General Court of the European Union / Court of First Instance

Abad Pérez and Others v Council and Commission Case T-304/01 [2006] ECR II-4857......134 AC - Treuhand AG v. Commission Case T-99/04 [2008] ECR - II 1501.....................28 Afrikanische Frucht-Compagnie GmbH v. Council and Commission Cases T-64 and 65/01

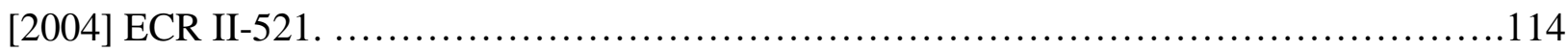

Aloys Schroder v. Commission Case T-390/94 [1997] ECR II-501.........................124 Arcelor SA v. European Parliament and Council Case T-16/04 [2010] ECR II211 $12,60,68,100,114,140$ Artegodan GmbH v. Commission Case T-429/05 ECLI:EU:T:2010:60_..................113 Atlantic Container Line AB and Others v. Commission Case T-113/04 [2007] E.C.R II-171...136 Bank Mellat v Council Case T-496/10 ECLI:EU:T:2013:39............................72 Bürgerausschuss für die Bürgerinitiative Minority SafePack - one million signatures for diversity in Europe v European Commission Case T-646/13 ECLI:EU:T:2017:59...........68 Camar Srl and Tico Srl v. Commission Cases T-79/96, 260/97 and 117/98 [2000] ECR II2193.

Chiquita Brands and Others v Commission Case T-19/01 [2005] ECR II-315, Case T$95 / 10$ 
Cindu Chemicals BV v. European Chemicals Agency (ECHA) EU:T:2013:108 60

Citymo SA v Commission of the European Communities Case T-271/04 [2007] ECR II01375 .

Coleman v. Attridge Law Case C-303/06 [2008] ECR I-5603.

Comité Central d'Entreprise de la Société Anonyme Vittel v. Commission Case T-12/93 [1995] ECR II-1247.

Comité Central de'Entreprise de la Société Générale des Grands Sources v. Commission Case

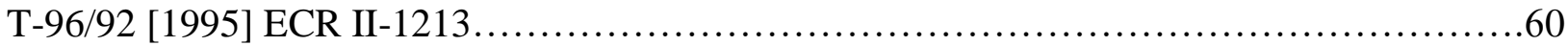

Comité de Salines de France v. Commission Case T-154/94 [1996] ECR II-1377................92

Commune de Champagne Case T-212/02, [2007] ECR II-2023 ................................75

Connaughton and Others v. Council Case T-541/93 [1997] ECR II- 549......................53

Corsica Ferries France v. Commission Case T-349/03 [2005] ECR II-2197. ....................54

Dorsch Consult Ingenieurgesellschaft mbH v. Council and Commission Case T-184/95 [1998]

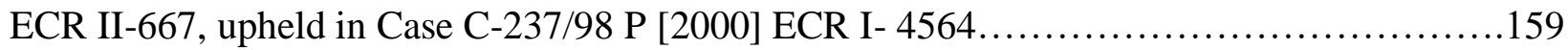

$E$ E. $R$. and Others $v$ Council of the European Union and Commission of the European Communities Case T-138/03 [2006] ECR II-04923 .......................................102

Eleftheriou and Papachristofi v Commission and ECB T-291/13 EU:T:2014:978_............121

ENU v. Commission Cases T-458 and 523/93 [1995] ECR II 2459........................... 124

Enviro Tech Europe Ltd and others v European Commission Case T-291/04 [2012] 2 CMLR 2 . 102

Evropaïki Dynamiki - Proigmena Systimata Tilepikoinonion Pliroforikis kai Tilematikis AE v European Commission Case T-9/10 [2013] ECR 0. .113

FIAMM v. Council and Commission Case T-69/00 [2005] ECR II-4549. $.160,161,163$

Front populaire pour la libération de la saguia-el-hamra et du rio de oro (Front Polisario) $v$ Council of the European Union Case T-512/12 ECLI:EU:T:2015:953.

FSL Holdings, Firma Léon Van Parys and Pacific Fruit Company Italy SpA v European Commission ECLI:EU:T:2015:383 Case T-655/11_......................................52

Galileo International Technology and Others v Commission Case T-279/03 [2006] ECR II-1291

Gascogne Sack Deutschland GmbH and Gascogne v European Union Case T-577/2014 ECLI:EU:T:2017:1 $128,142,156,281$ 
Inuit Tapiriit Kanatami $v$ European Parliament Case T-18/10 [2011] E.C.R. II-

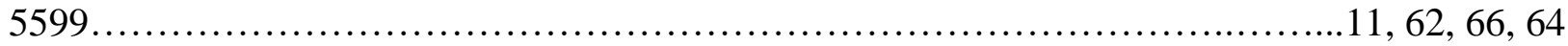

Jégo Quéré v. Commission Case T-177/01 [2002] ECR II-2365........................, 61, 67

Johannes Tomana and other v. Council Case T-190/12 ECLI:EU:T:2015:222_..........72, 76 Jose Maria Sison v. Council Case T-341/07 [2011] ECR II-07915...... 125, 126, 129, 185, 287 Kalliopi Nikolaou v. Commission Case T-259/03 [2007] ECR II-00099.................106, 140 Kaufring and Others v. Commission Cases T-187/97, T-190/97 to 192/97, T-210/97, T-211/97, T-216/97 to 218/97, T-279/97. T-280/97, T-191/97 and T-147/99 [2001] ECR II-1337. ... .68

Kendrion NV v. The European Union Case T-479/14 ECLI:EU:T:2017:48.... 127,144

KONGRA-GEL v. Council Case T-253/04 [2008] ECR II-46...............................56

Ledra Advertising v. Commission and ECB Case T-289/13 EU:T:2014:981_...............121

Lisrestal Case T-450/93 [1994] ECR II-117.........................................52

Lord Inglewood v. European Parliament Cases T-229 and 276/11 EU:T:2013:127...........57

Mannesmannrohren -Werke v. Commission Case T-112/98 [2001] ECR II- 729..............28

Mayr - Melnhof v. Commission Case T - 347/94 [1998] ECR II - 1751....................28

Medici Grimm v. Council Case T-364/03 [2006] ECR II-79................................113

Microban International Ltd $v$ European Commission Case T-262/10 [2011] E.C.R. II7697. $.60,62$

Mugraby Case T-292/09 [2011] ECR II-255.............................139, 174, 287

MyTravel Group plc v. Commission Case T-212/03 [2008] ECR II-1967...................113

Nölle Case T-167/94 [1995] ECR II-2589..........................................52

Oikonomopoulos v Commission, Case T-483/13 R. ECLI:EU:T:2016:421_...............103

Opel Austria v. Council Case T-115/94 [1997] ECR II-39....................205, 2011, 264

Organisation des Modjahedines du Peuple d'Iran (OMPI) v. Council Case T-228/02 [2006] ECR

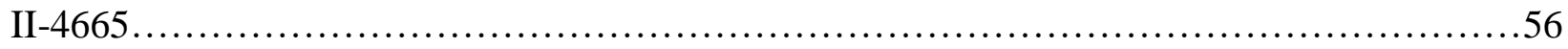

Othman v. Council and Commission Case T-318/01 EU:T:2009:187_...................56

Parliament v Council Case C-540/03 [2006] ECR I-5769..............................201

Pitsiorlas v Council and ECB [2007] Joined Cases T-3/00 and T-337/04 ECR II-4779.......121

Poulsen and Diva Navigation Case C-86/90 [1992] ECR I-6019.........................212

Richco Commodities Ltd v. Commission Case T-509/93 [1996] ECR II-1181_...............60 
Ring and Skouboe Werge v. Dansk amennyttigt Boligselskab Cases C-335 and 337/11 EU:C:2013:222.

Safa Nicu Sepahan Co. $v$ Council of the European Union Case T-384/11 ECLI:EU:T:2014:986. $.144,156,281$

Salamander v. European Parliament and Council Cases T-172, 175 and 177/98 [2000] ECR II2487. 60

Saint and Murray v. Council and Commission Case T-554/93 [1997] ECR II-563.... 50

Sogelma Case T- 411/06 [2008] ECR II-277................................... 170

Technoprocess v. Commission Case T-367 [2011] ECR II-209...........................98

The Health Food Manufacturers' Association and Others v European Commission Case T-

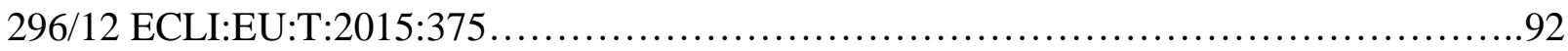

Theophilou v Commission and ECB Case T-293/13 EU:T:2014:97........................121

Trabelsi and Others v Council Case T-187/11 [2013] ECR 0.......................72, 105

Transational company 'Kazchrome’ AO v. Council Case T-192/08 [2011] ECR II-7449........51

Vichy v. Commission Case T-19/91 R [1991] ECR II-265................................ 104

Wafer Zoo v. Commission Case T-478/93 ECR 1995 II-1479............................136

Yusuf and Al Barakaat International Foundation v. Council and Commission Case T-306/01

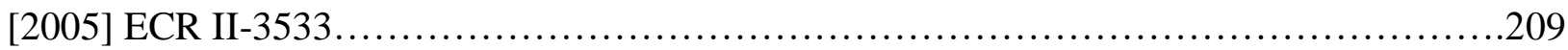

Yves Franchet and Daniel Byk v Commission of the European Communities Case T-48/05 [2008]

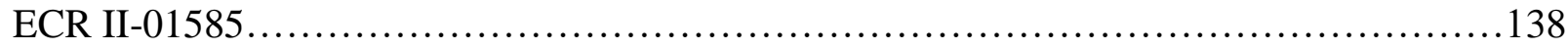

Zavvos v Commission Case T-21/01 [2002] ECR-SC I-A-101 and II-483...................138

C. Civil Service Tribunal

Aristidis Psarras v European Union Agency for Network and Information Security (ENISA), Case F-63/13 Judgment of the Civil Service Tribunal (First Chamber) of 2 July 2014.......141

D. Human Rights Review Panel for EULEX

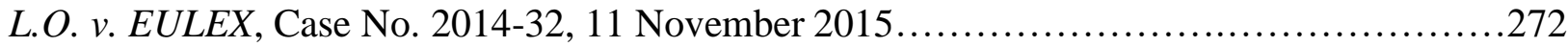


F. and Others against EULEX, Case 2011-27 follow up decision 11 June

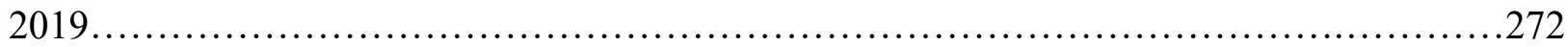

Valbone Zahiti v. EULEX Case No. 2012 - 144 February 2014..............................173

$X$ and 115 other complainants $v$. EULEX case no. 2011-20.............................272

$X$ and 115 other complainants v. EULEX, case no. 2011-20, Follow-up decision, 11 November 2011. 272

\section{COUNCIL OF EUROPE}

A. European Court of Human Rights

Al-Skeini v United Kingdom (merits and just satisfaction) (App No. 55721/07) ECtHR 7 July

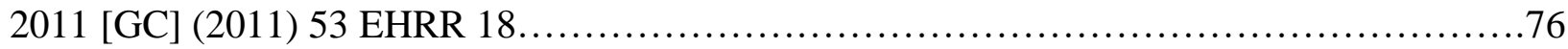
Assanidze v. Georgia (merits and just satisfaction) (App No. 71503/01) ECtHR 8 April 2004 ..42 Behrami and Behrami v. France (App. No 741412/01) ECtHR 2 May 2007 [GC] (2007) 45 EHRR SE10. $224,229,230,231$ Berić and others v. Bosnia and Herzegovina (admissibility) (Apps No. 36357/04, 36360/04, 38346/04, 41705/04, 45190/04, 45578/04, 45579/04, 45580/04, 91/05, 97/05, 100/05, 1121/05, $1123 / 05,1125 / 05,1129 / 05,1132 / 05,1133 / 05,1169 / 05,1172 / 05,1175 / 05,1177 / 05,1180 / 05$, 1185/05, 20793/05 and 25496/05) ECtHR 16 October 2007 (2001) 35 EHRR 3 ................229 Barbera, Messegué and Jabardo v. Spain (Article 50) (Application no. 10588/83) ECtHR 13 June 1994, Series A no. 285-C.... 44,150

Bosphoros Hava Yollari Turizm Ve Ticaret Anonim Sirketi v. Ireland (App No.45036/98) ECtHR 30 June 2005 (2006) 42 EHRR 1................................15, 126, 203, 213, 235, 283

Broniowski v. Poland (App no. 31443/96) ECtHR 22 June 2004 [GC] ECHR 2004-V........43, 45 Broniowski v. Poland (friendly settlement) (App no. 31443/96) ECtHR 28 September 2005 [GC]

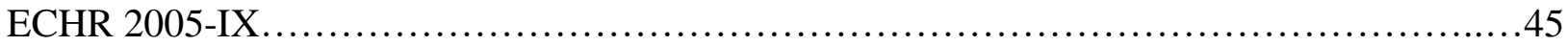

Çakici v. Turkey (App No. 23657/94) ECtHR 8 July 1999 [GC] (2001) 31 EHRR 13. $44,150,255$

Chagos Islanders v. United Kingdom (Admissibility) (App No. 35622/04) ECtHR 11 December 2012 (2013) 56 EHRR SE15. .77 
Chahal v. United Kingdom (Application No 22414/93) ECtHR 15 November 1996 (1997) 23 EHRR 413. .125

Cudak v. Lithuania (App. No. 15689/02) ECtHR 23 March 2010 [GC] (2010) 51 EHRR 15. .155

Cyprus v. Turkey (just satisfaction) (App. No. 25781/94) ECtHR 12 May 2014 .154

De Wilde, Ooms and Versyp v. Belgium (just satisfaction) (App. no. 2832/66; 2835/66; 2899/66) ECtHR 10 March 1972, [1972] ECHR 1 Series A no. 14. $44,149,151$

Dybeku v. Albania (App No. 41153/06) ECtHR 18 December 2007 [2007] ECHR 1109.........43

Eren v. Turkey (App No. 46105/98) ECtHR 23 October 2003...........................42

Ertak v. Turkey (App No. 20764/92) ECtHR 9 May 2000, ECHR 2000-V. $.44,150$

Firth and others $v$ United Applications nos. 47784/09, 47806/09, 47812/09, 47818/09, 47829/09, 49001/09, 49007/09, 49018/09, 49033/ 09 and 49036/09) ECtHR 15 December 2014 [2014] ECHR 874.........................152

Gajić v. Germany (admissibility) (App. No 31446/02) ECtHR 28 August 2007 ..............229 Gencel v. Turkey (App. No. 53431/99) ECtHR 23 October 2003..........................42 Golder v. United Kingdom (App. No. 4451/70) ECtHR 21 February 1975 (1975) 1 EHRR 524. .125

Halford v. the United Kingdom (Application No. 20605/92) ECtHR 25 June 1997, ECHR 1997III. 44,150

Hirst v United Kingdom (No. 2) (Application No. 74025/01) ECtHR 6 October 2005 (2006) 42 EHRR 41 .152 Ilaşcu v. Moldova (Application No. 48787/99) ECtHR 8 July 2004 [GC] (2005) 40 EHRR 46. 153

Isayeva Yusupova and Bazayeva v. Russia (Merits), ECtHR 24 February 2005 (2005) 41 EHRR 35 . 255

Jersild v. Denmark (App. No. 15890/89) ECtHR 20 October 1994, (1994) 19 EHRR 1 .151 Kadikis v. Latvia (no.2) (App. No. 62393/00) ECtHR 4 May 2006. $.44,150$

Kasumaj v. Greece (admissibility) (App. No. 6974/05) ECtHR 5 July 2007 .229

Kingsley v. The United Kingdom (App No. 35605/97) ECtHR 28 May 2002 [GC] (2002) 35 EHRR 177 150

Lahtonen v. Finland (App. No. 29576/09) ECtHR 17 January 2012 [2012] ECHR 44. .151 
Loizidou v. Turkey (Preliminary Objections) (App no. 16318/89) ECtHR 24 October 1995 (1995) 20 EHRR 99 .76

Loizidou v Turkey (Just Satisfaction) (App no. 16318/89) ECtHR 28 July 1998, ECHR 1998IV. 44,219

Maestri v Italy (App. No 39748/98) ECtHR 17 February 2004 (2004) 39 EHRR 38.............40 Maria Violeta Lăzărescu v. Romania (Application no. 10636/06) ECtHR 23 February 2010

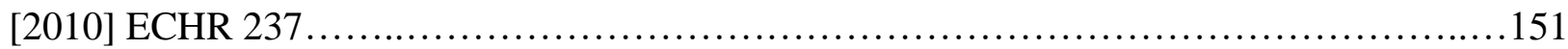

Marckx v. Belgium (App. No. 6833/75) ECtHR 13 June 1979 (1979) 2 EHRR 330............152 Matthew v. the Netherlands (App. No. 24919/03) ECtHR 29 September 2005...........44, 150 Matthews v. United Kingdom (App. No. 24833/94) 18 February 1999 (1999) 28 EHRR 361 35,235

Modinos v Cyprus (App.15070/89) ECtHR 22 April 1993, Series A. 259 (1994) 16 EHRR 485 $.43,44$ Olimpia - Maria Teodorescu v. Romania (App. No 43774/02) ECtHR 4 November 2008. .42

Özturk v. Turkey (App. No. 22479/93) 23 September 2009 [GC] ECHR 1999-VI. 151 Papamichalopoulos and Others v. Greece (Article 50) (App. No. 14556/89) ECtHR 31 October

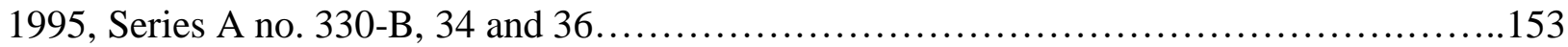

Pekerv. Turkey (App. No 53014/99) ECtHR 23 October 2003............................42

Piersack v. Belgium (Article 50) (App. 8692/79) ECtHR 26 October 1984...................125

Polufakin and Chernyshev v. Russia (App. No. 30997/02) ECtHR 25 September 2008........42

Ringeisen v. Austria, (Article 50) (App. No. 2614/65) ECtHR 22 June 1972 1972] ECHR 2...151

Saadi v. Italy (App. 32701/06) ECtHR 28 February 2008 [GC], (2009) 49 EHRR 730........125 Sabeh El Leil v. France (App no. 34869/05) ECtHR 29 June 2011 [GC] (2012) 54 EHRR 14.

Salduz v. Turkey (App. No. 36391/02) ECtHR 27 November [GC] (2008) 49 EHRR 421......42

Saramati v. France, Germany and Norway (App. No. 78166/01) ECtHR 2 May 2007 [GC] (2007) 45 EHRR SE10. $.224,225,229$

Scordino v. Italy (no.1) (App no. 36813/97) ECtHR 26 March 2006 [GC] ECHR 2006-V.....43

Sejdić and Finci v Bosnia and Herzegovina (App. No. 27996/06) ECtHR 22 December 2009 [2009] ECHR 2122..... 
Stec and others v. United Kingdom (Apps 65731/01 and 65900/01) ECtHR12 April 2006 [GC]

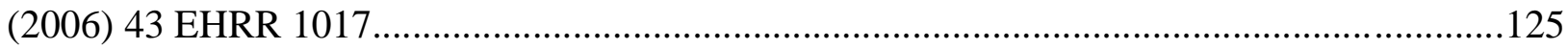

Strain and Others v. Romania (App no. 57001/00) ECtHR 15 December 2005 ECHR 2005-

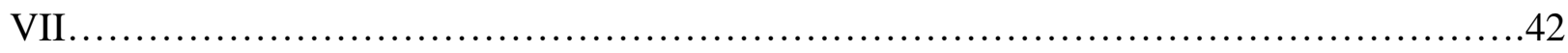

Texeira de Castro v. Portugal (Merits and Just Satisfaction) (App. No. 25829/94) ECtHR 9 June

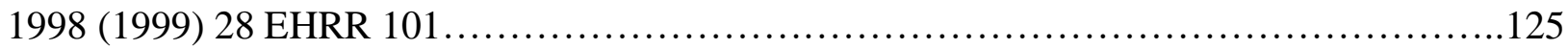

Verein gegen Tierfabriken Schweiz (VGT) v Switzerland (App. No. 32772/02) ECtHR 30 June

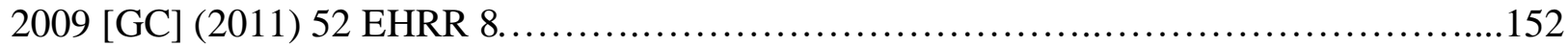

Wizerkaniuk v. Poland, (App. No 18990/05) ECtHR 5 July 2011......................... 151

B. European Commission of Human Rights

Ahmed v. Sweden (Application no. 9886/05) Commission's report of 22 February 2007.......45

Bulus v. Sweden, (Application no. 93390/81) Commission's report of 8 December 1984......45

Jager v. Switzerland (App. No 13467/87) Commission's report of 11 December 1989.........45

Melchior, (App. No. 13258/87) EComHR, Decision of 9 Feb. 1990, 64 D\&R 138.........235

Nagel v. Austria, (App. No 7614/76) Commission's report of 2 May 1978...................45

Zimmerman v. Austria, (App. No. 8490/79) Commission's report of 6 July 1982...........45

C. European Committee on Social Rights

Federation of employed pensioners of Greece (IKA-ETAM) v. Greece Complaint No. 76/2012,

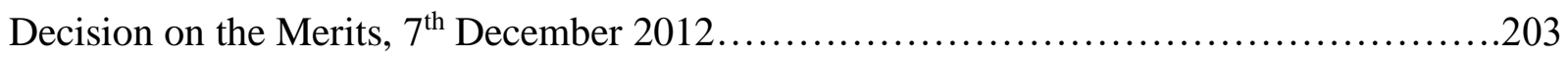

\section{III.UNITED NATIONS}

A. International Court of Justice

Advisory Opinion on the Interpretation of the Agreement of 25 March 1991, between the WHO

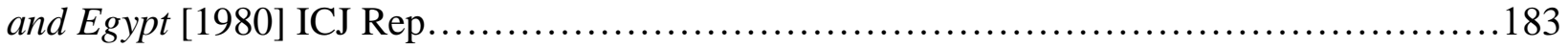


Application of the Convention on the Prevention and Punishment of the Crime of Genocide (Bosnia and Herzegovina v.Serbia and Montenegro), Judgment of the ICJ, 26 February 2007. 216, 220, 231

Barcelona Traction, Light and Power Company, Limited (Belgium v. Spain), Second Phase, Judgment of 5 Feb. 1970 [1970] ICJ Rep 3 .............................206, 207, 208, 213, 283 Case concerning territorial and maritime dispute between Nicaragua and Honduras (Nicaragua

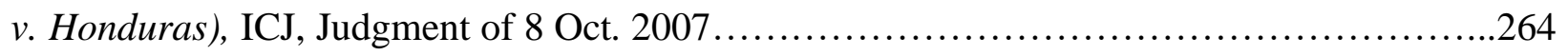
Case concerning delimitation in the Black Sea (Romania v. Ukraine), Judgment of 3 Feb. 2009, Corfu Channel, Merits ICJ Reports 1949, 35. 152,257

Difference Relating to Immunity from Legal Process of a Special Rapporteur of the Commission on Human Rights ICJ Reports 1999. $96,216,247,254$ Difference Relating to Immunity from Legal Process of a Special Rapporteur of the Commission on Human Rights Yearbook of the International Law Commission (1956) Vol. II................216 Factory at Chorzow (Merits) 1928 PCIJ, Series A, No. 17...................153, 249, 253, 250 Forests of Central Rhodope (Greece v. Bulgaria) 3 RIAA 1405. .251

Gabčikovo-Nagymaros Project (Hungary/Slovakia) ICJ Reports 1997. .253

Legal Consequences of the Construction of a Wall in the Occupied Palestinian Territory, Advisory Opinion, ICJ Reports 2004 .................................................. 246

Legality of the Threat or Use of Nuclear Weapons [1996] ICJ Rep 226.......................206 Legality of Use of Force (Yugoslavia v. France) (preliminary objections) (2002) .............238 Military and Paramilitary Activities in and against Nicaragua [1986] ICJ Rep 14 . 216-221

North Sea Continental Shelf, Judgment, ICJ Reports 1969..............................205

Reparations for Injuries Suffered in the Service of the United Nations (Advisory Opinion) 1949

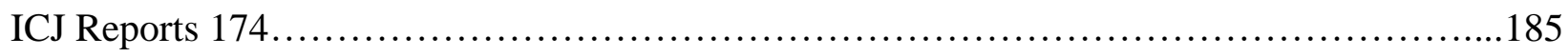

The German Interests in Polish Upper Silesia, Judgment of 25 May 1926, PCIJ, Series A, No 7. 205

Temple of Preah Vihear, Merits, Judgment, ICJ Reports 1962 .250

B. United Nations Human Rights Committee 
H.v.d.P. v. Netherlands Communication No 217/1986, UN Doc CCPR/C/29/D/217/1986, IHRL 2500 (UNHRC 1987), 8th April 1987, Human Rights Committee [UNHRC] .............202-204

Wilson v. Philippines, 11 November 2003, HRC Communication No. 868/1999................255

Quinteros v. Uruguay, 21 July 1983, HRC Communication No. 107/1981....................258

Khalilova v. Tajikistan, 30 March 2005, HRC Communication No. 973/2001...................258

Sultanova v. Uzbekistan, 20 March 2006, HRC Communication No. 915/2000................258

C. United Nations Committee Against Torture

Guridi v. Spain CAT Communication No. 212/2002 .....................................257

D. International Criminal Tribunal for the Former Yugoslavia

Prosecutor v. Duško Tadić, International Tribunal for the Former Yugoslavia, Case IT-94-1-A (1999),ILM,vol. 38, No. 6 (November 1999).

$.217,220$

\section{INTERAMERICAN COURT OF HUMAN RIGHTS}

Aloeboetoe et al v. Suriname, Reparations and Costs, 10 September 19993, Interamerican Court

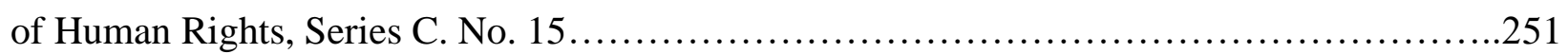
Bulacio v. Argentina Merits Reparations and Costs 18 September 2003, Interamerican Court of

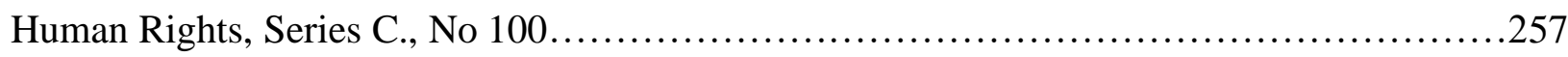

Juan Humberto Sanchez v. Honduras Merits, Reparations and Costs, 7 June 2003, Interamerican

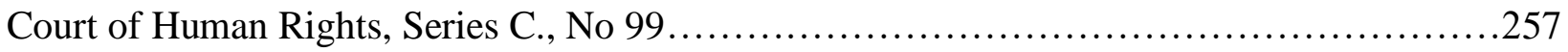

Pueblo Bello Massacre v. Colombia, Merits, Reparations and Costs 31 January 2006, Interamerican Court of Human Rights, Series C., No. 140...................................252 Velasquez Rodriguez v. Honduras, Reparations and Costs, 21 July 1989, Interamerican Court of Human Rights Series C., No. 7 ..................................................255-256

Mapiripan Massacre v. Colombia, Merits, Reparations and Costs, 15 September 2005, Interamerican Court of Human Rights Series C., No 134 ................................258 
Plan de Sanchez Massacre v. Guatemala, Merits, 29 April 2004, Interamerican Court of Human

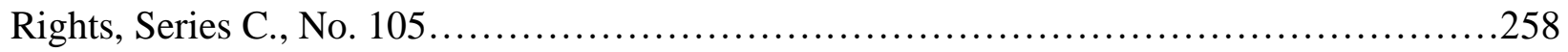

Rochela Massacre v. Colombia, Merits, Reparations and Costs, 11 May 2007, Interamerican Court of Human Rights, Series C., No. 163 ..........................................258

Trujillo- Oroza v. Bolivia, Reparations and Costs, 27 February 2002, Interamerican Court of

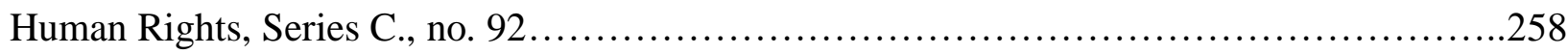

\section{WORLD TRADE ORGANISATION}

EC - Measures Concerning Meat and Meat Products (Hormones), WT/DS26................197

EC - Regime for the Importation, Sale and Distribution of Bananas, WT/DS27..............197

European Communities - Geographic Indications, Panel Report WT/DS174/R..............234

European Communities - Selected Customs Matters, WT/DS315//AB/R....................234

\section{UNITED STATES - IRAN CLAIMS TRIBUNAL}

American International Group Inc v. Iran 4 Iran-USCTR 96 (1983).......................255

Starrett Housing Corporation v. Iran 16 Iran - USCTR 112 (1987).......................255

\section{OTHER INTERNATIONAL TRIBUNALS}

Case concerning the difference between New Zealand and France concerning the interpretation or application of two agreements concluded on 9 July 1986 between the two States and which related to the problems arising from the Rainbow Warrior affair, UNRIAA, vol. XX (Sales No.

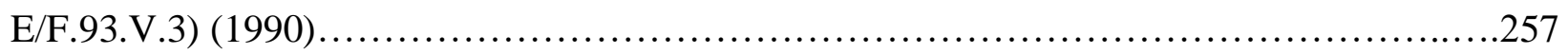

Hôtel Métropole case, UNRIAA, vol. XIII (Sales No. 64.V.3), (1950).......................250

Martini case, UNRIAA, vol. II (Sales No. 1949. V.1)(1930). ............................251

Dispute concerning responsibility for the deaths of Letelier and Moffitt (United States v. Chile)

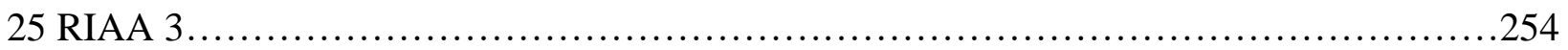

Lusitania Cases (United States v. Germany) 7 RIAA 32.................................255 


\section{NATIONAL CASE LAW}

A. Cyprus

Republic via the Advocate General v. Argyris Georgiou (2003) 1 CLR 704....................148

Takis Yiallouros v. Eugenios Nicolaou (2001) 1 CLR 558.................................148

B. France

Assistance publique, Hôpitaux de Paris CE 29 March 2000 D. 2000, 563......................96

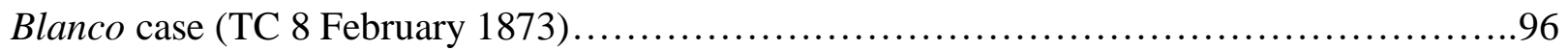

Décision Cons Const 13 December 1985, Rec. cons. Const 780.............................96

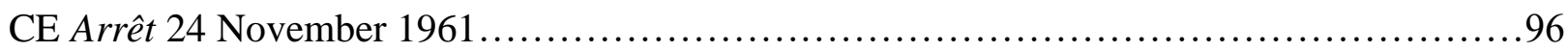

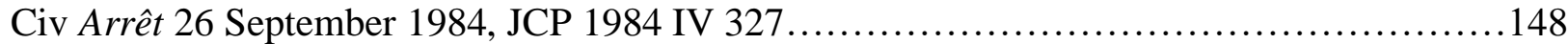

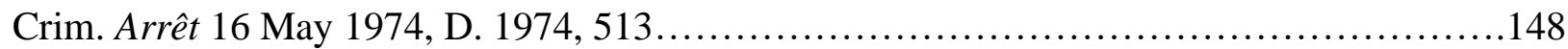

Letisserand, Rec. CE 1961, 661 GAJA................................................96

C. Germany

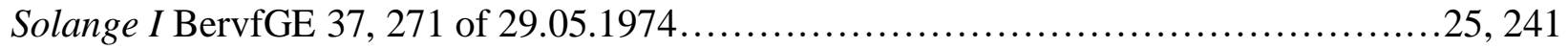

Judgment of 12 March 1987 of the Bundesgerichtshof, Juristen Zeitung, 1987, p. 1024........114

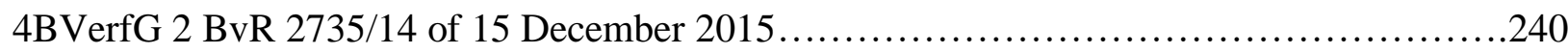

D. Ireland

Hanrahan v Merck Sharp and Dohme (Ireland) Ltd [1988] IESC 1.........................148

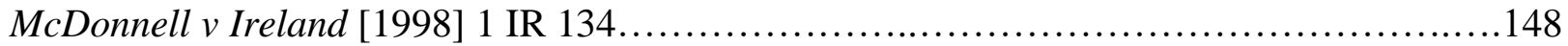

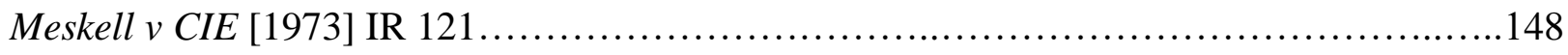

E. United Kingdom 
$R$ (Greenfield) v. Secretary of State for the Home Department [2005] UKHL 14...............147

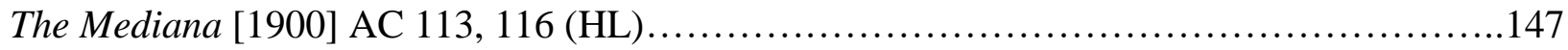

Van Colle v. Chief Constable of the Hertfordshire Police [2007] EWCA Civ 325.............147

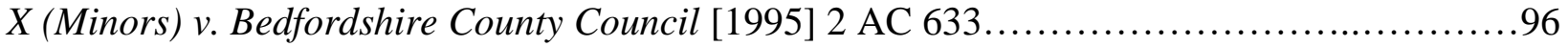

F. The Netherlands

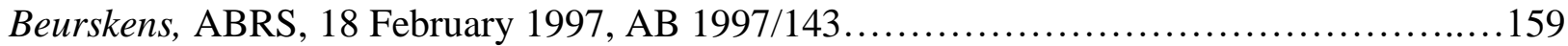

Hasan Nuhanovič v. the Netherlands, Court of Appeal in The Hague, Civil Law Section (5 July 2011), LJN: BR5388;200.020.174/01; ILDC 1742 (NL 2011)..........................226

Mehida Mustafič-Mujič, DamirMustafič, and Alma Mustafič v. the Netherlands, Court of Appeal in The Hague, Civil Law Section (5 July 2011), LJN:BR5386; 200.020.173/01 (NL 2011)...226 The State v. Lavrijsen, Hoge Road der Nederlanden, 30 March 2001, NJ 2003/615, AB

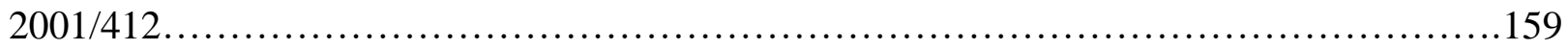

Van Vlodrop, ABRS, 6 May 1997, AB 1997/229. ...............................159,164

G. Spain

Tribunal Constitucional, Orden 6922-2008, June 9, 2011_...........................240 


\section{TABLE OF LEGISLATION AND INSTRUMENTS}

Commission Decision 2013/478/EU of 27 September 2013, amending Decision 1999/352/EC, ECSC, Euratom establishing the European Anti-fraud Office, OJ L 257.................11, 97

Commission Decision (EU) 2015/512 of 25 March 2015 amending Decision 1999/352/EC, ECSC, Euratom establishing the European Anti-fraud Office OJ L 81.................11, 97

Council Decision 2013/34/CFSP of 17 January 2013 on a European Union Military Mission to Contribute to the Training of the Malian Armed Forces (EUTM Mali) OJ 2013 L14/19.......230

Council Decision 2010/427/EU of 26 July 2010 establishing the organisation and functioning of the European External Action Service, OJ 2010, L201/30..........................74, 189

Council Decision 2009/371/JHA of 6 April 2009 establishing the European Police Office (Europol) OJ L 121 171,287

Council Directive 79/7/EEC of 19 December 1978 on the progressive implementation of the principle of equal treatment for men and women in matters of social security OJ L 6 .

Council Directive 92/85/EEC of 19 October 1992 on the introduction of measures to encourage improvements in the safety and health at work of pregnant workers and workers who have recently given birth or are breastfeeding (tenth individual Directive within the meaning of Article 16 (1) of Directive 89/391/EEC) OJ L 348.

Council Directive 2000/43/EC of 29 June 2000 implementing the principle of equal treatment between persons irrespective of racial or ethnic origin OJ L 180

9, 199

Council Directive 2000/78/EC of 27 November 2000 establishing a general framework for equal treatment in employment and occupation OJ L 303

$115,125,199$ 
Council Directive 2004/113/EC of 13 December 2004 implementing the principle of equal treatment between men and women in the access to and supply of goods and services OJ L 373.

Council Directive 2010/18/EU of 8 March 2010 implementing the revised Framework Agreement on parental leave concluded by BUSINESSEUROPE, UEAPME, CEEP and ETUC and repealing Directive 96/34/EC OJ L 68

Council Framework Decision 2002/584/JHA of 13 June 2002 on the European arrest warrant and the surrender procedures between Member States. $.68,238$

Council Framework Decision 2008/913/JHA of 28 November 2008 on combating certain forms and expressions of racism and xenophobia by means of criminal law OJ L 328.

Council Joint Action 2005/797/CFSP of 14 November 2005 on the European Union Police Mission for the Palestinian Territories OJ L 300.

Council Joint Action 2008/851/CFSP of 10 November 2008, on a European Union military operation to contribute to the deterrence, prevention and repression of acts of piracy and armed robbery off the Somali coast, OJ L 301. .83

Council Joint Action 2008/124/CFSP of 4 February 2008 on the European Union Rule of Law Mission in Kosovo, EULEX KOSOVO OJ L 42 $.93,270$

Council Regulation (EC) No 2007/2004 of 26 October 2004 establishing a European Agency for the Management of Operational Cooperation at the External Borders of the Member States of the European Union OJ L 349 . $.11,68,171$

Council Regulation (EU) 2016/1686 imposing additional restrictive measures directed against ISIL (Da'esh) and Al-Qaeda and natural and legal persons, entities or bodies associated with them, 20 September 2016 OJ L 255. 
Council Regulation (Euratom) No 1074/1999 of 25 May 1999 concerning investigations conducted by the European Anti-Fraud Office (OLAF) OJ L 136_......................11, 97

Directive 2006/54/EC of the European Parliament and of the Council of 5 July 2006 on the implementation of the principle of equal opportunities and equal treatment of men and women in matters of employment and occupation (recast) OJ L 204. 199

Draft Articles on the Law of Treaties with Commentaries Yearbook of the International Law Commission 1966, Vol II (UN Doc A/CN.4/SER.A/1966/Add. 1)............................207

Draft Articles on the Responsibility of International Organisations, with Commentaries Yearbook of the International Law Commission, 2011, vol. II, Part Two.........196, 216, 222$229,236,237,244-248,256-263$

Draft Articles on the Responsibility of States for Internationally Wrongful Acts, with Commentaries Yearbook of the International Law Commission, 2001, vol. II, Part Two $196,216,220,237,221,254$

EULEX KOSOVO, Human Rights Review Panel, Rules of Procedure 173

European Convention on Human Rights and Fundamental Freedoms. $5,6,8$ 15,22 - 48, 56, 80, 125, 150, 151, 153, 175, 176, 193, 219, 271, 272

European Union Charter of Fundamental Rights $14,15,25,51,52,55,56$ 73, 100, 106, 114, 116, 124, 171, 193, 214, 223, 268, 271, 284

Human Rights Act (United Kingdom) 1998 $15,83,147,148,156$

International Covenant on Civil and Political Rights $20,40,179,202,262,271$ 
International Covenant on Economic, Social and Cultural Rights

$.40,200,271$

Proposal for a Regulation of the European Parliament and of the Council on the European Union Agency for Law Enforcement Cooperation and Training (Europol) and repealing Decisions 2009/371/JHA and 2005/681/JHA. <http://register.consilium.europa.eu/doc/srv?l=EN\&f=ST\%2010033\%202014\%20INIT> ...272

Regulation (EC) No 1073/1999 of the European Parliament and of the Council of 25 May 1999 concerning investigations conducted by the European Anti-Fraud Office (OLAF) OJ L 136. 11,97

Regulation (EC) No 45/2001 of the European Parliament and of the Council of 18 December 2000 on the protection of individuals with regard to the processing of personal data by the Community institutions and bodies and on the free movement of such data OJ L 8.....171, 287

Regulation (EU) No 1077/2011 of the European Parliament and of the Council of 25 October 2011 establishing a European Agency for the operational management of large-scale IT systems in the area of freedom, security and justice OJ L 286

171,286

Regulation (EU) 2016/794 of the European Parliament and of the Council of 11 May 2016 on the European Union Agency for Law Enforcement Cooperation (Europol) and replacing and repealing Council Decisions 2009/371/JHA, 2009/934/JHA, 2009/935/JHA, 2009/936/JHA and 2009/968/JHA OJ L 135 .......................................11, 68, 94, 97, 172, 290

Regulation (EU) No 526/2013 of the European Parliament and of the Council, of 21 May 2013 concerning the European Union Agency for Network and Information Security (ENISA) and repealing Regulation (EC) No 460/2004................................... 171, 286

Regulation (EU, Euratom) No 883/2013 of the European Parliament and of the Council of 11 September 2013 concerning investigations conducted by the European Anti-Fraud Office 
(OLAF) and repealing Regulation (EC) No 1073/1999 of the European Parliament and of the Council and Council Regulation (Euratom) No 1074/1999, OJ L 248..................11, 97

Resolution of the Institut de droit international Annuaire de l'Institut de droit international (1954-II) 45 .264

Treaty on the European Union (mentioned as a whole and not individual provisions) $6,14,55,189,191$

Treaty on the Functioning of the European Union (mentioned as a whole and not individual provisions) $49,55,190$

United Nations Convention on the Law of the Sea.... $.76,265$

United Nations Convention on the Rights of Persons with Disabilities. $8,179,198,200,213,258,263,269,283$

United Nations General Assembly, Resolution 60/147, on the Basic Principles and Guidelines on the Right to a Remedy and Reparation for Victims of Gross Violations of International Human Rights Law and Serious Violations of International Humanitarian Law. . . $.247,248,250,254,256,257,258,259,260,295$

UN Human Rights Committee (HRC), General comment no. 31 [80], The nature of the general legal obligation imposed on States Parties to the Covenant, 26 May 2004, CCPR/C/21/Rev.1/Add.13.........................................208, 258

Vienna Convention on the Law of Treaties... $64,65,206$ 


\section{INDEX}

A

accession to the European Convention on

Human Rights 6, 8, 10, 11, 13, 22-48, 288

accountability of the EU for human rights

violations $10,14-17,20,24,29,32,73-78$,

$93,94,173,183,280-286$

action for annulment $8,10,22,49-80,113$, $184,92,97,105,112,113,148$

actors 166

international 16, 75, 174, 193- 195, 294

legal 73,75

non-state 181-187

administration 234,258

of justice 271

administrative act $35,39,46,67,112,166$,

234, 266, 294

administrative law 59, 96, 149, 159

admissibility criteria $62,77,229,89,150$, 169

advisory opinion 183, 185, 267 advocate general 52, 61, 66, 76, 90, 114, $161,170,200$

agencies of the European Union 11, 80, 81, $93,107,67,68,169-173,286,287$

agents of states or international organisations 217, 223, 226, 229, 233, 247

annulment (see action for annulment)

Appellate Body (WTO) 234

arbitral tribunal 249, 251, 256

arbitration 98, 256

Area of Freedom, Security and Justice (AFSJ) 67, 68, 171, 287

assembly, freedom of 214,284

association, freedom of 214, 283

asylum 56, 269, 289

ATAA case $34,197,212$

attribution, doctrine of 4, 20, 180, 187, 197, $215-232$

autonomy of EU law 11, 15, 32 - 38, 185

B

banks 12, 27, 69, 72, 108, 167, 279-280

Barcelona Traction 206-208, 212, 283 
Basic Law of the Federal Republic of Germany 96, 114, 240

basic principles 247,257

binding effect of ECtHR judgments 36-48

border control 11, 68, 171-172, 187, 193

breach 40, 46, 62, 102

of international human rights

obligations 195-215

sufficiently serious 116-129

Bundesgerichtshof 114

Bundesverfassungsgericht 240

C

causation 98, 102, 133-155, 174, 247, 281

Charter of Fundamental Rights 16, 14, 25,

$26,28,51,55$, ,67, 73, 100, 115, 116, 125,

$127,192,193,271$

Citizens 9, 30, 40, 100, 31

rights of $51,55245,250$

Civil Service Tribunal 141

co-respondent mechanism 31, 32, 36, 242, 284

Commission (see European Commission)
Common Foreign and Security Policy (CFSP) 68, 70-75, 79, 88, 90, 91, 169-173, $181-195$

Common Security and Defence Policy 83, 93, 189, 190-201, 216, 220-238, 244, 266, $271,273,290$

compensation 43. 44. 97, $105-107,113$, $124,116,121,149,150-158,137,139,252-$ 256

competence $6,9,50,55,67-70,173$ - 177

complaint $3,19,21,80,93,94,173,200-$

204, 245, 263, 270, 272, 289

conferral of rights $99,100,102,110,112$, $113,116,124,125,129,130,164,165,266$

constitution 14, 24, 25, 27, 28, 148, 172, 239,240

of Cyprus 148

of Ireland 148

constitutional courts 240,241

constitutional law 164, 234

constitutional value 29,130

contractual liability 98

Costa v. ENEL 37 
Council of Europe 5, 7, 29, 30, 31, 47, 183, 200, 204, 234

Council of Ministers 188, 90

Court of First Instance (CFI) 66, 106, 135,

$138,160,163,170$

Court of Justice of the European Union

(CJEU) 12, 22, 25, 26

jurisdiction in judicial review

$67-79$

jurisdiction in damages actions 166-

177

approach to nominal damages 146155

Convention Against Torture 179, 257

criminal law 241, 242

Convention for the Rights of Persons with

Disabilities 8, 179, 213, 200, 213, 258, 262, 269,283

CSDP (see Common Security and Defence Policy)

customary international law 179, 186, 195, 205-215, 222, 245, 250, 252, 260, 284

D damage $96,97,103,163,200,113-155$, 246-249

financial 97, 99, 147, 172, 252

material 254, 260, 280, 295

moral 96, 135, 142, 254, 255, 280

damages $254,255,257,260,277,278$

action 96-179

data protection 171

decision - making 53, 73, 144, 170, 177,

266, 282

declaratory judgments 145-156

defence, rights of 52, 241

deficit of remedies 22-96

delegated acts 59, 27, 59, 60

democracy 62

deprivation of liberty 193

development, right to 269,289

direct concern 58, 60

direct effect of EU law 9, 19, 22, 33, 80-84, 199, 200, 213

directives 5, 59, 233, 236

disability (see also Convention for the Rights of Persons with Disabilities) 198, 199 
discretion, 12, 46, 58, 65, 93, 112, 116, 117 , $123,158,164,167,160,217,221,280,287$ grave disregard to the limits of 12 , $110,112,116117,123,124$

discretionary acts $124-132$

Draft Articles on the Responsibility of International Organisations 196, 216, 222229, 236, 237, 244-248, 256-263

Draft Articles on the Responsibility of States for Internationally Wrongful Acts 196, 216, $220,237,221,254$

$\mathbf{E}$

economic activity $112,116-118,138$

economic freedom 18, 130, 132

effective remedy $58,65,67,88,91,167$, $193,225,272,282$

employment 100, 155, 199, 228, 250-254

enforcement 11, 68, 93, 97, 171, 172, 192, 259,279

of judgments $45,46,47$

of EU law 86

of obligations 13, 197, 202, 274, $275,295,291$ equal treatment $9,82,85,116,117,199$

Directive 2004/113 on access to and supply of goods and services 199

Framework Employment Directive 199

Race Directive 199

Recast Equal Treatment Directive $115,125,199$

erga omnes $87,91,207-208$

Essential procedural requirements 51-55, 113

consultation and participation 53, 61,

92

duty to give reasons 52,114

right to be heard 51, 52, 92

European Arrest Warrant (EAW) 68, 69, $238,239,241$

European Central Bank (ECB) 50, 108, 170, 183,279

European Coal and Steel Community (ECSC) 5 
European Commission 13, 25, 45, 58, 59, 64, 69, 108, 121, 124, 168, 172, 177, 176,

190, 197, 203, 206, 222, 234, 267, 279, 289

European Convention on Human Rights and Fundamental Freedoms (ECHR) 7, 11, 12,

$14,15,19,20,27,28,32,33,36,37,39,40$, 42, 127, 127, 151, 175, 176, 200, 244, 265, 267, 288

remedies of 39-45

European Communities 5, 13, 30, 37, 52, $160,181,234$

pillars of 6,68

European Council 188, 230, 236

European Court of Auditors 106

European Court of Justice (see Court of Justice of the European Union)

European Court of Human Rights (ECtHR)

$3,20,22,26-48,225,229,234,235252$, 255,255

approach to nominal damages 146155

binding effect of ECtHR judgments $36-48$
European Economic Area 37

European External Action Service (EEAS)

$74,75,189,286$

European Economic Community (EEC) 6

European Free Trade Association (EFTA)

37

European Parliament 5, 9, 11, 12, 27, 30 58, 59,172

European Social Charter 203, 204

Europol 11, 68, 171, 172, 177, 282

exchange of letters $63,269,285,289$

exclusive jurisdiction $37,38,50,83,99$, 166,175

execution of judgments 30, 39-47, 152, 227

external action 15, 139, 149, 173, 193, 199, $233,242,284$

external borders 11, 68, 171, 172, 187, 193

F

fair trial 42, 53, 97, 125, 127, 141, 155, 167, $177,239,279$

family life 106, 135, 137, 141, 159, 201, 250

fault liability $158-163,281$

financial damage 97, 99, 147, 172, 252 
foreign policy 20, 74, 188, 189

Francovich 114

freezing measures 126

FRONTEX 11, 68, 80, 94, 171, 177, 193,

$278,252,290$

fundamental rights, terminology $17-22$

Charter of (see Charter of $\mathbf{H}$

\section{Fundamental Rights)}

Fundamental Rights Agency (FRA) 140,

175

G

gender equality 199

general application (measures or acts of) 59,

61,92

General Court of the European Union

(GCEU) 52, 61-64, 72, 104, 108, 139, 141-

$143,174,279$

general measures 32, 42-48, 62, 76, 251, 258,277

general principles of EU law 24, 25, 26, 27,

$34,54,56,57,99,100,113,114,117,137$,

$162,163,173,250$

non-discrimination 82, 198, 199 precautionary principle 27

proportionality $27,68-72,85,123$,

124, 130-132, 163, 164, 280

transparency 57,53

sustainable development 12

good administration 51

harmonisation 85

hierarchy of norms 36, 39, 211

High Authority 53, 54, 57

High Representative of the Union for Foreign Affairs and Security Policy 74, 188-

191

horizontal 148, 211

effect 82,83

human dignity 18, 20, 55, 100, 179, 241, 290

human rights $17-22$

norms 12, 19, 87, 102, 182, 178,

$275,285,293$

rules 102 
international 7, 8, 15, 19, 20, 22 25, $56,70,63,139,165,195-215,235-$ 241,288

instruments 19, 25, 40, 56, 206, 208, $250,253,271,258$

Universal Declaration of 5, 18, 182

\section{I}

illegality 3, 8, 19, 49, 80, 92, 169, 260, 278

implementing acts 27, 59, 62

implementing measures 58, 65

individual applicants 3, 11, 12, 14, 49, 50,

$61,66,79,86,91,104,276,277,287$

infringement 50,54, 69, 92, 99, 102, 107,

112- 124, 141, 174, 237279

infringement of an essential procedural

requirement (see essential procedural

requirements)

infringement of the Treaties or a rule

relating to their application $55-58$

institutionalisation of the CSDP 190-191

international human rights $25,34,56,139$, $195-215$ law 7, 8, 15, 19, 20, 22 25, 56, 70, 63, 139, 165,195-215, 235-241, 288 norms 12, 19, 87, 102, 182, 178, $275,285,293$

obligations $8,20,26,70,78,139$, 146, 179, 181, 195-215, 205, 212, $213,215,223,242,244,259,283$, 284, 291

international legal order 15, 193, 205, 210, 211

international organisations 46, 140, 174, 175, 180, 182 - 187, 196, 215, 222, 224, 244 invalidity, declaration of 84,87 irreparable damage 104

\section{$\mathbf{J}$}

judicature 48, 87, 98, 140, 197, 277, 282

judicial review in EU law 49-79

judicial system 13, 20, 36, 48, 106, 227, $262,267,282,287$

jus cogens 20, 205-212, 179

just satisfaction 22, 43-48, 147 19, 150-157

$\mathbf{K}$

Kadi case (2008) 25, 26, 56, 71 
Kadi (GCEU) 209

Kelsen, Hans 186

$\mathbf{L}$

lawfulness 97, 98, 51

legal act 59, 73, 75, 153, 223

legal basis 31, 50, 73, 266

legal person 53, 58, 59, 61, 70, 71, 74, 88,

$89,168,179,215,225,226,231,246$

international 185, 235, 266, 282

legal personality $1,6,20,184$

international 14, 179, 181-195

legal remedy 10, 11, 31, 49, 84, 106, 230, $272,278,279$

legal system 15, 40, 158, 160, 161, 244

national $148-155,43,45,160,164$ $227,234,257$

of the EU 4, 10, 12, 22, 24, 27, 33, $39,65,71,72,79,93,96,278,292$, 294

legality, review of $55,75,78,93,154,268$, 276

legally binding 59, 170, 176 legislation $7,9,34,35,57,76,100,115$, $119,120,286,291$

primary (see primary law) secondary 34, 35, 100, 124, 211, $239,240,246$

legislative acts $27,50,53,59,63,160,188$, 249

legislative reform 29,43

lex specialis 115

Lisbon Treaty 6, 9, 10, 57, 62, 63, 68, 70, $71,73,202$

litigation 12, 71, 86, 157, 163, 209, 213, 266

Locke 18

M

Maastricht Treaty 6

manifest disregard of the limits of discretion 117

manifestation of religion 278

manifestly deficient protection of human

rights 203

misuse of powers 50, 54, 113

monist system 33

Mugraby case 139, 174 
multilateral treaties 198-202, 262, 283

$\mathbf{N}$

national courts $9,25,34,36$ 63, 66, 81, 82, $83,86,90,91,98,131,146,155,166,176$, 234

national law (see national legal system)

negotiations 31,122

NGOs 196

Nice Treaty 6

non-contractual liability 3, 21, 69, 96-179

criteria 102-104

for lawful acts 158-166

legal basis $99-106$

scope $166-177$

non-discrimination 82, 198, 199

non-legislative 59,62 102

norms 28, 37, 54, 87, 102, 124, 179, 193, 203, 206, 207, 208, 209

hierarchy of 36, 39, 211, 246285 286

human rights $12,19,87,102,182$, $178,275,285,293$

nulla poena sine lege certa 88 nullity, declaration of 187

$\mathbf{O}$

objections 145

preliminary 76,238

obligations $33,34,37,180,195-215$

erga omnes $87,91,207-208$

international 222

international human rights $8,20,26$, 70, 78, 139, 146, 179, 181, 195-215, $205,212,213,215,223,242,244$, $259,283,284$

omissions 45, 99, 104, 140, 174, 216, 222, 248

Opinion 1/91 37-38

Opinion 1/00 39

Opinion 2/94 14

Opinion 2/13 32, 90, 175, 202, 243, 267 284-288

opinion, advisory $64,77,176,246,267,183$, 185

\section{$\mathbf{P}$}

pacta tertiis nec nocent nec prosunt 298

Panel (WTO) 197, 234

Panel (Human Rights Review for EULEX) $9,80,93,94,262,270-273$ 
Parliamentary Assembly of the Council of Europe 30, 183

pecuniary damages $162,153,155$

peremptory norms 179, 206, 209, 213, 45,

$246,249,250,274,283,285$

Plaumann test 8, 60, 61, 112, 113

plea of illegality 9, 19, 23, 80, 92-94, 278

precedent 40, 45, 155, 255

precautionary principle 27

preliminary reference $9,16,19,22,2690$ -

94,278

preliminary ruling $38,76,81-91,161,239$, 267

President of the Commission 25, 188

President of the Court of Justice of the EU

30,105

President of the European Council 188

primary law 27, 32, 25, 26, 51, 98, 174, 180,

$213,223,239,240$

privacy 9, 107, 136, 156

private applicants 66

private life $85,97,100,195 \mathrm{~m} \mathrm{127,135,136,}$ $175,214,283$ procedural rights 52,53

property, right to $12,13,27,43,69,72,101$, $108,115-123,127,138,162,168,169,209$, $213,280,283$

proportionality $27,68-72,85,123,124$, 130-132, 163, 164, 280

public interests 115

public law 82, 112

$\mathbf{R}$

racism 199

recommendations 50, 173, 200, 272, 273, 289

redress $7,12,13,29,33,37,35,47,48,79$, $91,137,159,166,277$

remedies 7-9, 16, 19, 22-48

access to $10,13,15,29,32,37,47$, $67,73,87,93,125,155,168,225$, 247, 259284

deficit 22-96

effective 58, 65, 67, 88, 91, 167, 193, $225,272,282$

for breaches of international law 249-252 
judicial 31, 65, 66, 81, 85, 90, 231

legal 10, 11, 31, 49, 84, 106, 230, $272,278,279$

substantive $3,7,8,12,17,22,24,30$,

$32,33,29,42,47,48,58,67,83$,

104, 105, 196, 276, 277

regulations $67,72,177,233,234,236,282$

regulatory acts 58-60, 62-63

resolutions 47, 64, 209, 210

restitution 42-48, 153, 247-256, 260, 275,

277,285

restriction of rights $50,71,108,115120$ -

124, 162, 164, 165, 193, 201

restrictive measures 70-79, 88-89, 144-146,

175

review (see judicial review)

of legality 55, 75, 78, 93, 154, 268, 276

reviewable acts $12,50,53,69,71,278$

rights $17-12$

based claims 111, 116, 124, 133,

158-166, 276, 266 conferral of 99, 100,102,110,112,

$113,116,124,125,129,130,164$,

165,266

fundamental 17 - 22

human (see human rights)

of the defence 52, 241

property $12,13,27,43,69,72,101$, $108,115-123,127,138,162,168$, $169,209,213,280,283$

$\mathbf{S}$

sanctions 46, 47, 74, 75, 177, 192, 203, 211, 256

satisfaction $248,256-259,280$ just $22,43-48,147$ 19, 150-157

Schöppenstedt 97, 102, 110, 170

schutznorm 114-115

Single European Act (SEA) 6

social rights 203 (see also European Charter

of Social Rights)

specific damage 149

soft law 187, 221, 224

sovereign rights 37

sovereignty $47,76-77,257$ 
sufficiently serious breach 12, 110-127, 161, 1757

supremacy of EU law 26, 2882

standing 58-79

state liability in EU law 111, 112

state responsibility in international law 196, $220,221,222,224,247,254,256$

supranational 6, 184, 233, 242

Supreme Court of Ireland 148

Supreme Court of the Republic of Cyprus

148

$\mathbf{T}$

territory $9,44,57,63,75,76,220,246$

terrorism 77, 85, 104, 172, 189, 210

Toth A.G. 140

torture, prohibition and freedom from 173,

179, 207, 208, 213, 257, 272, 283

transparency 57,53

Transocean case 52

Tribunal Constitucional 239

$\mathbf{U}$

uncertainty $142,143,144$ unlawfulness $3,19,98,100,142,144,156$, $161,162,164,169,174,279$ in damages actions 110-133 in judicial review 8, 83, 87

United Nations 183, 185, 189, 193, 201, 202 $-209,230,242,246,253,246,253,254,259$

United Nations Convention on the Law of the Sea 76, 265

United Nations Human Rights Committee 202, 204, 208, 258, 283

Universal Declaration of Human Rights 5, 18,182

$\mathbf{V}$

validity $34,36,66,68,81-89,90,94,200$, $210,212,278$

value $1,16,18,24,25-29,49,55,56,129$, $130,206,254,255,257$

Vienna Convention on the Law of Treaties 64, 65, 206

W

Wessel R, 15, 70, 73, 74, 184, 194, 202, 205, 2012

World Human Rights Court 273 
World Trade Organisation (WTO) 160, 163, xenophobia 199

$197,233,234,243$

$\mathbf{Z}$

$\mathbf{X}$

Zaoui 139, 174 


\section{CURRICULUM VITAE}

Alexis E. Antoniades was born on June $4^{\text {th }}, 1990$ in Limassol, Cyprus. He received his secondary education in Cyprus at the Grammar School, Limassol. He holds an LLB in English and European Law (First Class Honours, 2011) from Queen Mary, University of London, a Certificat Supérieur en Droit Français et Européen (Assez Bien, 2010) from Université Panthéon - Assas, Paris II, and an LLM in International Law (Merit, 2012) from University College London. He registered as an advocate at the Supreme Court of the Republic of Cyprus and the Cyprus Bar Association in 2015, and practised in the areas of civil law, administrative law and human rights for five years. He is currently an international relations officer in the International Affairs Service of the House of Representatives of the Republic of Cyprus. He is fluent in Greek, English, French and Spanish. 